Supporting Information for:

\title{
Decarbonylative Fluoroalkylation at Palladium(II): From Fundamental Organometallic Studies to Catalysis
}

Naish Lalloo, Christian A. Malapit, S. Maryamdokht Taimoory, Conor E. Brigham, and Melanie S. Sanford*

Department of Chemistry, University of Michigan, 930 North University Avenue, Ann Arbor, Michigan 48109, United States

\section{Table of Contents}

I. General information $\mathbf{S 2}$

II. Materials and methods $\quad 52$

III. Compatibility experiments S2

IV. Procedure and spectral data for stoichiometric decarbonylation studies 58

V. Synthesis, isolation, and spectral data for complex II-CHF 2

VI. Procedure and spectral data for stoichiometric transmetalation studies S15

VII. Procedure for synthesis of aryl neopentyl boronate esters S19

VIII. Procedure for catalytic reaction with fluoroalkyl and fluoride salts

IX. Synthesis of DFAF solution in tetrahydrofuran $\quad$ S28

X. Optimization for catalytic aryl difluoromethylation with DFAF S30

XI. Catalysis procedure

XII. Other substrates explored S38

XIII. Computational methods $\quad S 40$

XIV. Computational data and discussion S41

XV. References $\quad \mathbf{S 4 7}$

XVI. X-Ray crystallography data for II-CHF 2

XVII. ${ }^{1} \mathrm{H},{ }^{13} \mathrm{C},{ }^{1 \mathrm{~s}} \mathrm{~F}$, and ${ }^{31} \mathrm{P}$ NMR spectral data 


\section{General information}

All manipulations were performed inside an $\mathrm{N}_{2}$-filled glovebox unless otherwise noted, and all glassware was ovendried for a minimum of $24 \mathrm{~h}$ in an oven at $150 \stackrel{\circ}{\circ}$ before use. NMR spectra were obtained on a Varian VNMR 700 (699.76 MHz for $1 \mathrm{H} ; 175.95 \mathrm{MHz}$ for $\left.{ }^{13} \mathrm{C}\right)$, Varian VNMR $500\left(500.09 \mathrm{MHz}\right.$ for ${ }^{1} \mathrm{H} ; 470.56 \mathrm{MHz}$ for ${ }^{19} \mathrm{~F} ; 125.75 \mathrm{MHz}$ for $\left.{ }^{13} \mathrm{C}\right)$, or Varian VNMR $400\left(401 \mathrm{MHz}\right.$ for ${ }^{1} \mathrm{H}$; $376 \mathrm{MHz}$ for ${ }^{19} \mathrm{~F} ; 123 \mathrm{MHz}$ for $\left.{ }^{13} \mathrm{C}\right)$ spectrometer. ${ }^{1} \mathrm{H}$ and ${ }^{13} \mathrm{C}$ NMR chemical shifts are reported in parts per million (ppm) relative to TMS, with the residual solvent peak used as an internal reference. ${ }^{19} \mathrm{~F}$ NMR chemical shifts are reported in ppm and are referenced to 4-fluorotoluene $(-119.85 \mathrm{ppm})$ or trifluoromethoxybenzene $(-58.00 \mathrm{ppm}) .{ }^{13} \mathrm{C}$ NMR spectra are referenced to the residual $\mathrm{CHCl}_{3} \mathrm{peak}(77.16 \mathrm{ppm})$. Abbreviations used in the NMR data are as follows: s, singlet; d, doublet; t, triplet; q, quartet; m, multiplet; br, broad signal. Yields of reactions that generated fluorinated products were determined by ${ }^{19} \mathrm{~F}$ NMR spectroscopic analysis using a relaxation delay of $5 \mathrm{~s}$ with a $90^{\circ}$ pulse angle. Mass spectral data were obtained on a Micromass Magnetic Sector Mass Spectrometer. Automated flash chromatography was performed using a Biotage Isolera One system with cartridges containing high performance silica gel.

Abbreviations: tetrahydrofuran (THF), dichloromethane (DCM), diethyl ether $\left(\mathrm{Et}_{2} \mathrm{O}\right)$, difluoroacetyl fluoride (DFAF), difluoroacetic anhydride (DFAAn), trifluoroacetic anhydride (TFAAn), difluoroacetic acid (DFA), trifluoroacetic acid (TFA), pentafluoropropionic anhydride (PFPAn), pentafluoropropionic acid (PFPA), tetramethyl ammonium fluoride (TMAF), tetrabutylammonium fluoride (TBAF), room temperature (RT).

\section{Materials and methods}

All commercially available reagents were used as received unless otherwise stated. $\mathrm{Pd}\left[\mathrm{P}(\mathrm{o}-\mathrm{Tol})_{3}\right]_{2}$ (Strem, Alfa Aesar), phosphine ligands (Strem, CombiBlocks, Sigma Aldrich, Oakwood Chemicals), cesium fluoride (Acros), tetramethylammonium fluoride (Manchester), and fluoroalkyl anhydrides (Oakwood Chemicals) were stored in a $\mathrm{N}_{2}-$ atmosphere glovebox. Aryl boronic acid and aryl bromide precursors were purchased from commercial sources (Sigma Aldrich, Alfa Aesar, Matrix Scientific, Frontier Scientific, Synquest, TCI America, Oakwood Chemicals) and used as received, unless stated otherwise. Deuterated solvents were purchased from Cambridge Isotope Laboratories, Inc.

\section{Compatibility experiments [Table 1 of manuscript]}

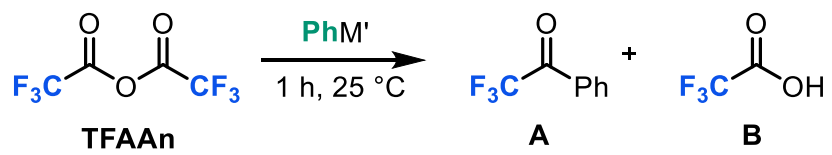

A. Trifluoroacetic anhydride and diphenyl zinc. A THF solution (0.5 M) of trifluoroacetic anhydride was prepared, and $0.1 \mathrm{~mL}$ of this solution was added to a pre-weighed vial containing a stir bar and $\mathrm{Ph}_{2} \mathrm{Zn}(11 \mathrm{mg}, 0.05 \mathrm{mmol}$, 1.0 equiv). The solution was diluted to $0.4 \mathrm{~mL}$ with THF, sealed with a Teflon-lined cap, and stirred at room temperature for $1 \mathrm{~h}$. 4-Fluorotoluene $\left(0.025 \mathrm{~mL}, 2.0 \mathrm{M}, 0.05 \mathrm{mmol}, 1.0\right.$ equiv) was added as a ${ }^{19} \mathrm{~F}$ NMR standard, the solution was transferred to an NMR tube, and the reaction was analyzed via ${ }^{19} \mathrm{~F}$ NMR spectroscopy. 2,2,2- 
trifluoromethyl acetophenone A was formed in $77 \%$ yield (signal at $-72.4 \mathrm{ppm}$ ) with no remaining anhydride. A broad signal attributed to a zinc trifluoromethyl acetate was also observed at $-76.2 \mathrm{ppm}$ as shown below in Figure S1.

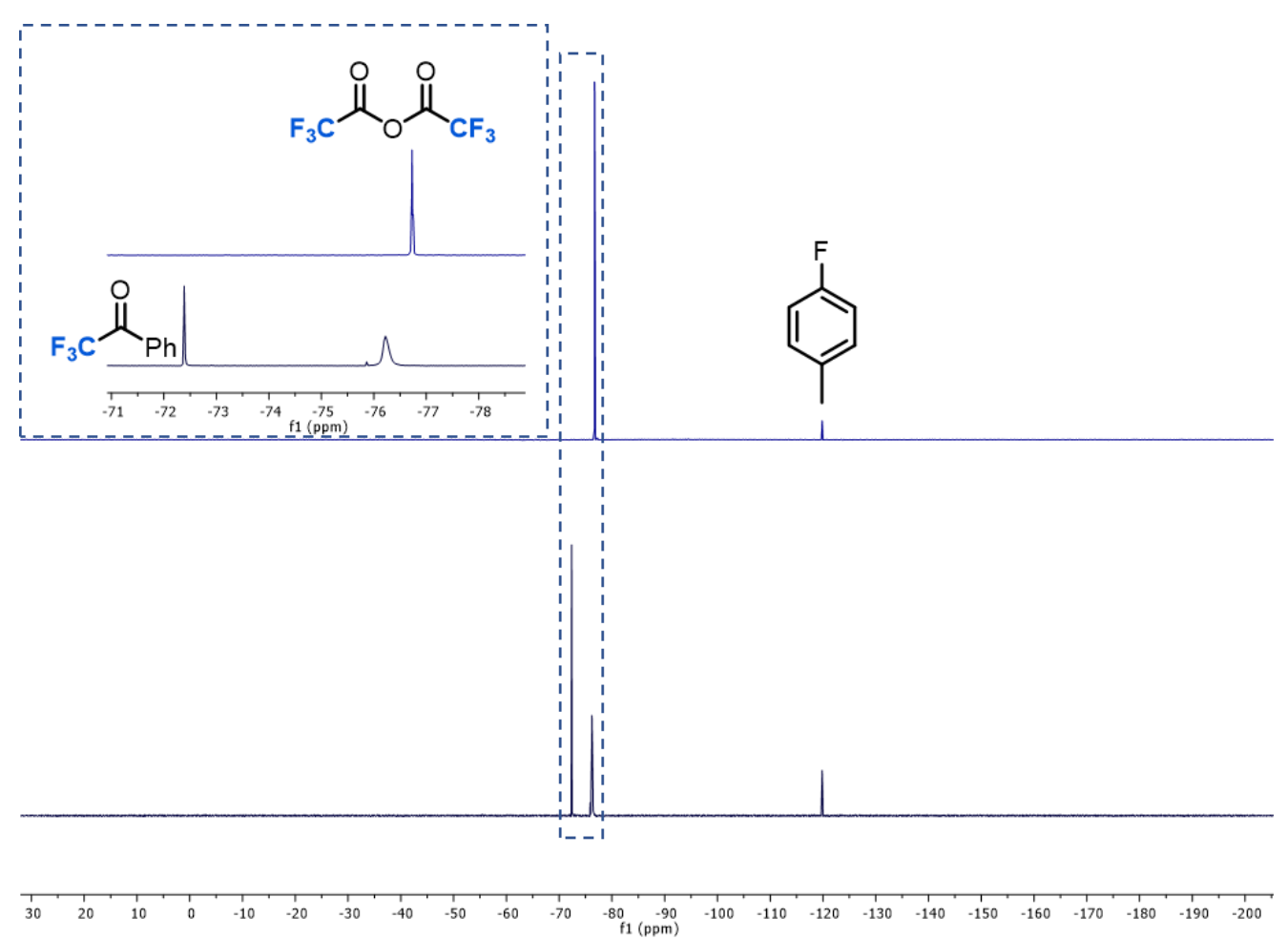

Figure S1. Incompatibility of $\mathrm{Ph}_{2} \mathrm{Zn}$ with trifluoroacetic anhydride (TFAAn) in THF as shown by (top) ${ }^{19} \mathrm{~F}$ NMR spectrum of TFAAn with 4-fluorotoluene internal standard, and (bottom) ${ }^{19} \mathrm{~F}$ NMR spectrum of reaction of TFAAn with diphenyl zinc after $1 \mathrm{~h}$ in THF showing formation of ketone $\mathbf{A}$.

B. Trifluoroacetic anhydride and phenyl boronic acid. $\mathrm{A} \mathrm{CDCl}_{3}$ solution $(1.0 \mathrm{M})$ of trifluoroacetic anhydride was prepared, and $0.3 \mathrm{~mL}$ was added to a pre-weighed vial containing a stir bar and $\mathrm{PhB}(\mathrm{OH})_{2}(36 \mathrm{mg}, 0.30 \mathrm{mmol}, 1.0$ equiv). The solution was diluted to $0.4 \mathrm{~mL}$ with $\mathrm{CDCl}_{3}$, sealed with a Teflon-lined cap, and stirred at room temperature for $1 \mathrm{~h}$. The reaction solution was transferred to an NMR tube and analyzed by ${ }^{13} \mathrm{C}$ NMR spectroscopy. $\left({ }^{13} \mathrm{C}\right.$ rather than ${ }^{19} \mathrm{~F}$ NMR was used, because the former allows more clear differentiation of the $\mathrm{CF}_{3}$-containing products, vide infra.) As shown in Figure $\mathrm{S} 2$, trifluoroacetic acid $(\mathbf{B})$ is the major $\mathrm{CF}_{3}$-containing product formed under these conditions. Conducting the experiment in THF or toluene with analysis by ${ }^{19} \mathrm{~F}$ NMR spectroscopy led to inconclusive results due to the poor resolution between TFAAn and TFA in the ${ }^{19} \mathrm{~F}$ NMR spectra.

C. Trifluoroacetic anhydride with phenylboronic acid neopentylglycol ester. $\mathrm{A} \mathrm{CDCl}_{3}$ solution $(1.0 \mathrm{M})$ of trifluoroacetic anhydride was prepared, and $0.3 \mathrm{~mL}$ was added to a pre-weighed vial containing a stir bar and phenylboronic acid neopentylglycol ester $\left(54 \mathrm{mg}, 0.30 \mathrm{mmol}\right.$ ). The solution was diluted to $0.4 \mathrm{~mL}$ with $\mathrm{CDCl}_{3}$, sealed with a Teflon-lined cap, and stirred at room temperature for $1 \mathrm{~h}$. The solution was transferred to an NMR tube, and ${ }^{13} \mathrm{C}$ NMR analysis was conducted. After $1 \mathrm{~h}$ or $3 \mathrm{~h},{ }^{13} \mathrm{C}$ NMR spectroscopic analysis showed that neither A nor B was formed (Figure S2). Conducting the experiment in THF or toluene followed by analysis via ${ }^{19} \mathrm{~F}$ NMR 
spectroscopy led to inconclusive results due to the poor resolution between TFAAn and TFA in the ${ }^{19} \mathrm{~F}$ NMR spectra.

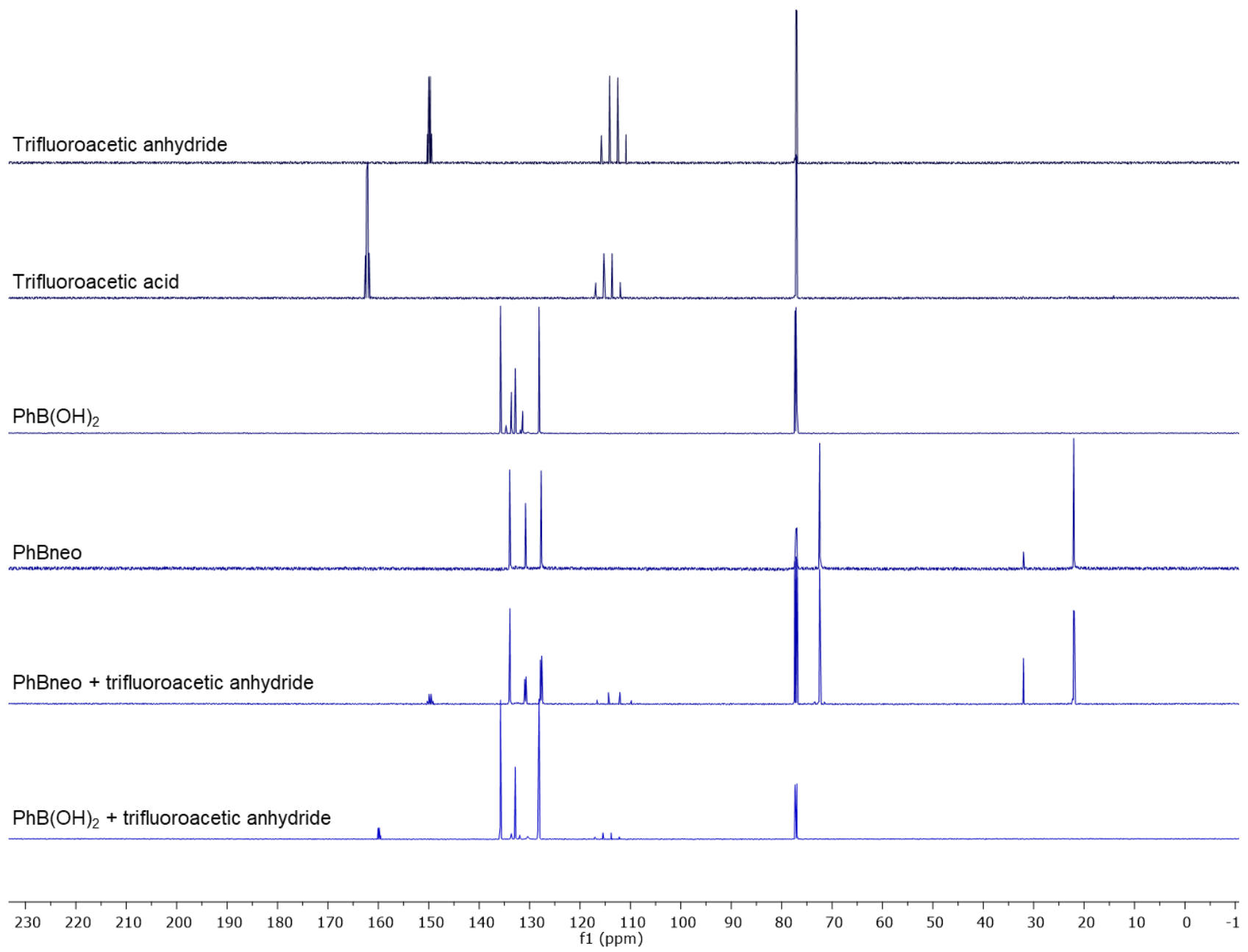

Figure S2. Compatibility experiments of organoboron nucleophiles with trifluoroacetic anhydride after $1 \mathrm{~h}$ at room temperature in $\mathrm{CDCl}_{3}$ as shown by ${ }^{13} \mathrm{C}$ NMR spectroscopy.

D. Trifluoroacetic anhydride with phenylboronic acid neopentylglycol ester at $\mathbf{5 0} \stackrel{\circ}{ } \mathbf{C} . \mathrm{A} \mathrm{CDCl}_{3}$ solution $(1.0 \mathrm{M})$ of trifluoroacetic anhydride was prepared, and $0.3 \mathrm{~mL}$ was added to a pre-weighed vial containing a stir bar and phenylboronic acid neopentylglycol ester $\left(54 \mathrm{mg}, 0.30 \mathrm{mmol}\right.$ ). The solution was diluted to $0.4 \mathrm{~mL}$ with $\mathrm{CDCl}_{3}$, sealed with a Teflon-lined cap, and stirred at $50{ }^{\circ} \mathrm{C}$ for $1 \mathrm{~h}$. The reaction was cooled to room temperature. The solution was transferred to an NMR tube and ${ }^{13} \mathrm{C}$ NMR analysis was conducted, showing a small amount of trifluoroacetic acid B (Figure S3). 


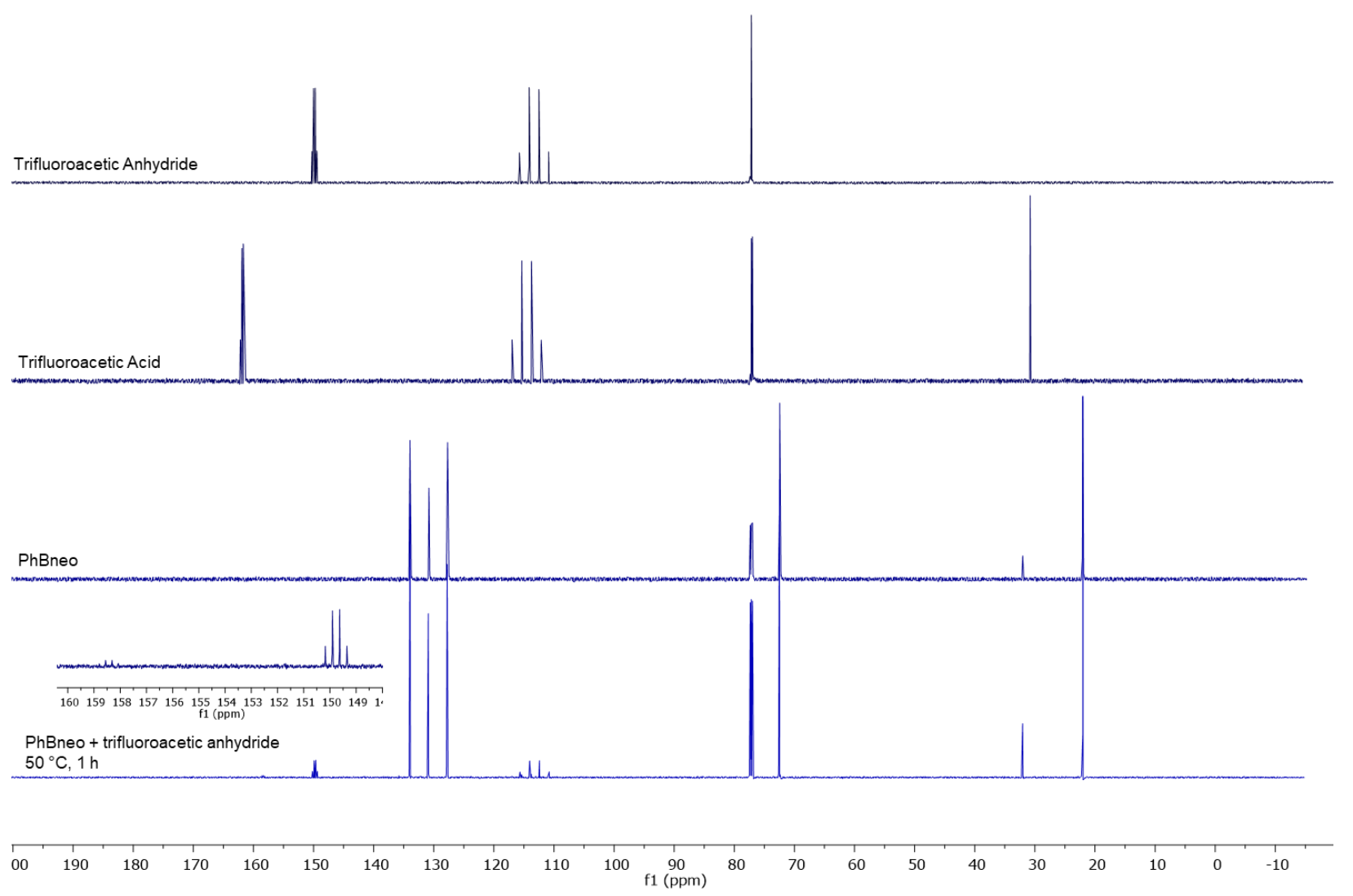

Figure S3. ${ }^{13} \mathrm{C}$ NMR spectrum showing minor amount of decomposition of trifluoroacetic anhydride to trifluoroacetic acid in the presence of phenylboronic acid neopentylglycol ester after $1 \mathrm{~h}$ at $50^{\circ} \mathrm{C}$ in $\mathrm{CDCl}_{3}$.

E. Trifluoroacetic anhydride with phenylboronic acid pinacol ester. $A \mathrm{CDCl}_{3}$ solution (1.0 M) of trifluoroacetic anhydride was prepared, and $0.3 \mathrm{~mL}$ was added to a pre-weighed vial containing a stir bar and phenylboronic acid pinacol ester (61 mg, $0.30 \mathrm{mmol}$ ). The solution was diluted to $0.4 \mathrm{~mL}$ with $\mathrm{CDCl}_{3}$, sealed with a Teflon-lined cap, and stirred at room temperature for $1 \mathrm{~h}$. The mixture was transferred to an NMR tube and ${ }^{13} \mathrm{C}$ NMR spectroscopic analysis was conducted. Neither A nor B was detected (Figure S4). 


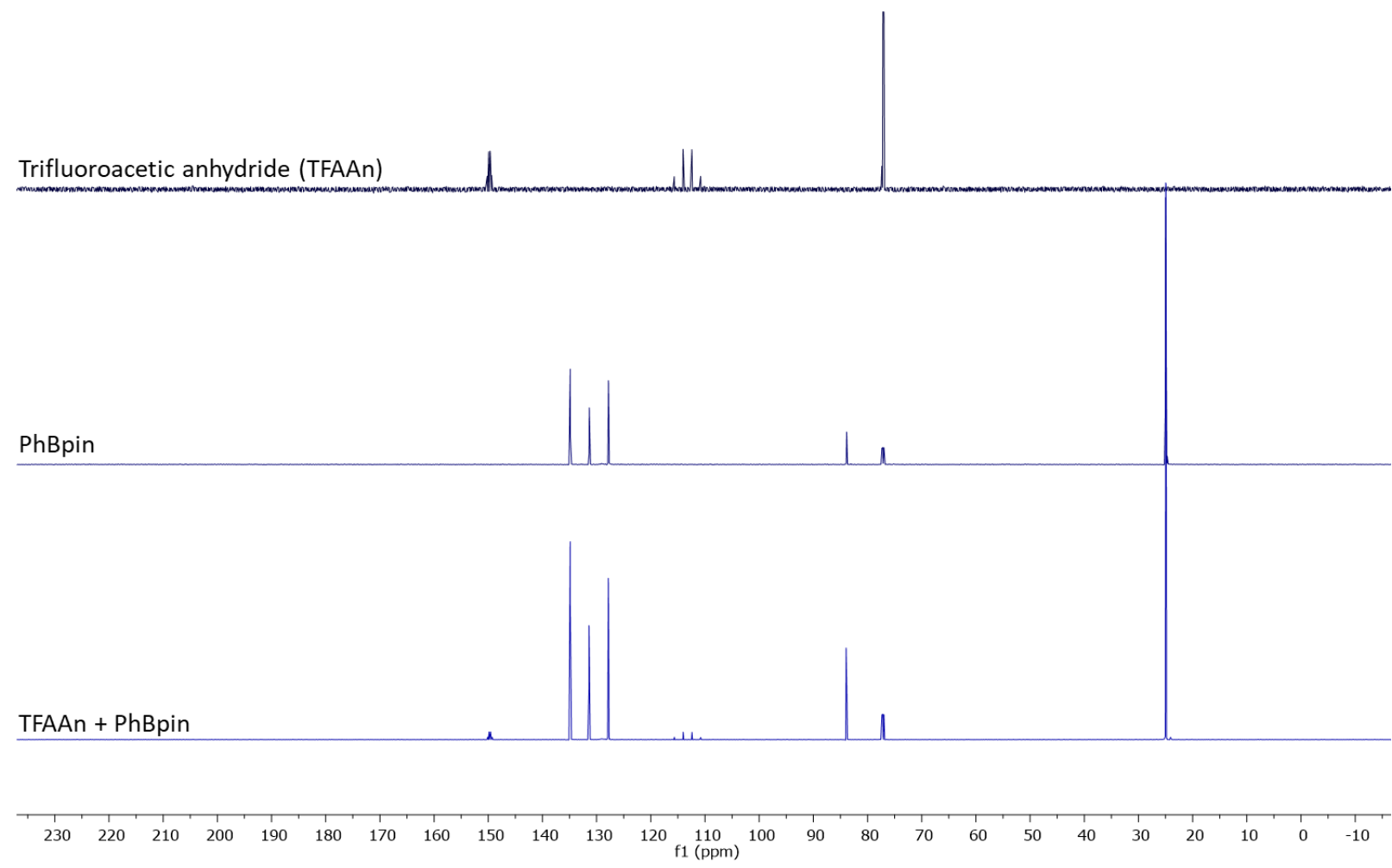

Figure S4. Compatibility of phenylboronic acid pinacol ester with trifluoroacetic anhydride after $1 \mathrm{~h}$ at room temperature in $\mathrm{CDCl}_{3}$ as shown by ${ }^{13} \mathrm{C}$ NMR spectroscopy.

F. Difluoroacetic anhydride with phenyl boronic acid. $\mathrm{A} \mathrm{CDCl}_{3}$ solution $(1.0 \mathrm{M})$ of difluoroacetic anhydride was prepared, and $0.15 \mathrm{~mL}$ was added to a pre-weighed vial containing a stir bar and $\mathrm{PhB}(\mathrm{OH})_{2}(18 \mathrm{mg}, 0.15 \mathrm{mmol}$, 1.0 equiv). The solution was diluted to $0.4 \mathrm{~mL}$ with $\mathrm{CDCl}_{3}$, sealed with a Teflon-lined cap, and stirred at room temperature for $1 \mathrm{~h}$ at room temperature. The solution was transferred to an NMR tube and ${ }^{13} \mathrm{C}$ NMR analysis was conducted, which showed complete hydrolysis of DFAAn to form difluoroacetic acid (DFA) (Figure S5).

G. Difluoroacetic anhydride with phenylboronic acid neopentylglycol ester. $A \mathrm{CDCl}_{3}$ solution $(1.0 \mathrm{M})$ of difluoroacetic anhydride was prepared, and $0.15 \mathrm{~mL}$ was added to a pre-weighed vial containing a stir bar and phenyl boronate ester $\mathbf{1 b}(26 \mathrm{mg}, 0.15 \mathrm{mmol})$. The solution was diluted to $0.4 \mathrm{~mL}$ with $\mathrm{CDCl}_{3}$, sealed with a Teflonlined cap, and stirred at room temperature for $1 \mathrm{~h}$ at room temperature. The solution was transferred to an NMR tube, and ${ }^{13} \mathrm{C}$ NMR analysis was conducted, which showed no detectable DFA (Figure S5). 


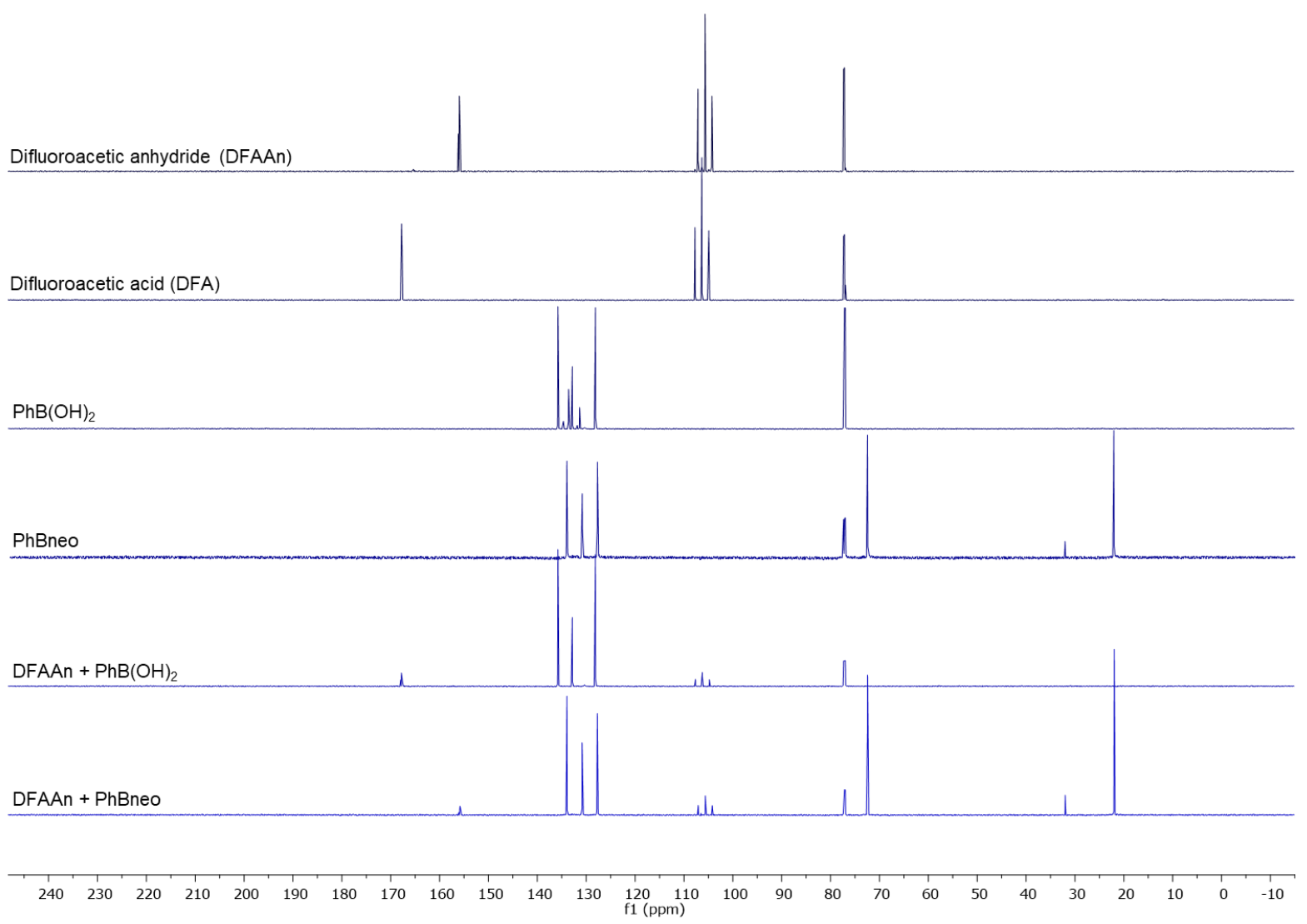

Figure S5. Compatibility experiments of organoboron nucleophiles with difluoroacetic anhydride after $1 \mathrm{~h}$ at room temperature in $\mathrm{CDCl}_{3}$ as shown by ${ }^{13} \mathrm{C}$ NMR spectroscopy.

H. Difluoroacetyl fluoride with phenyl boronic acid. A solution of $\mathrm{PhB}(\mathrm{OH})_{2}(12 \mathrm{mg}, 0.10 \mathrm{mmol}, 1.0$ equiv) in 0.4 $\mathrm{mL}$ THF was prepared. To this was added a THF solution of DFAF $(0.035 \mathrm{~mL}, 2.85 \mathrm{M}, 0.10 \mathrm{mmol}, 1.0$ equiv), and the reaction was sealed with a Teflon-lined cap and stirred at room temperature for $1 \mathrm{~h}$. 4-fluorotoluene $(0.05 \mathrm{~mL}$, $2.0 \mathrm{M}, 0.10 \mathrm{mmol}, 1.0$ equiv) was added as an internal standard, the solution was transferred to an NMR tube, and ${ }^{19} \mathrm{~F}$ NMR analysis was conducted. No DFAF was detected in solution, as shown in Figure S6. Instead, a doublet at $-128.45 \mathrm{ppm}$ appeared, which corresponds to the hydrolysis product DFA.

I. Difluoroacetyl fluoride with phenylboronic acid neopentylglycol ester. A solution of PhBneo (19 mg, 0.10 mmol, 1.0 equiv) in $0.4 \mathrm{~mL}$ THF was prepared. To this was added a THF solution of DFAF $(0.035 \mathrm{~mL}, 2.85 \mathrm{M}, 0.10$ mmol, 1.0 equiv), and the reaction was sealed with a Teflon-lined cap and stirred at room temperature for $1 \mathrm{~h} .4-$ fluorotoluene $(0.05 \mathrm{~mL}, 2.0 \mathrm{M}, 0.10 \mathrm{mmol}, 1.0$ equiv) was added as an internal standard, the solution was transferred to an NMR tube, and ${ }^{19} \mathrm{~F}$ NMR analysis was conducted. Less than $3 \%$ DFA was observed in solution, as shown in Figure $\mathrm{S} 6$. 


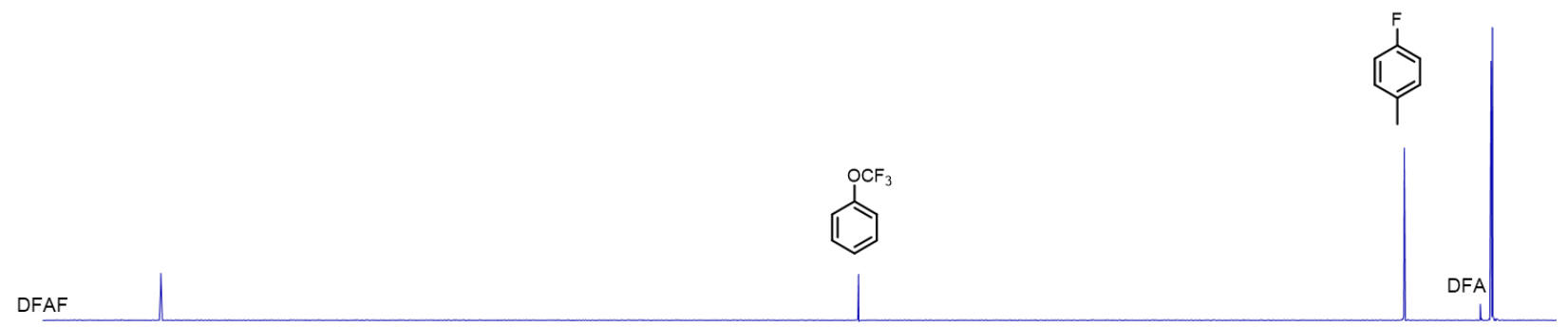

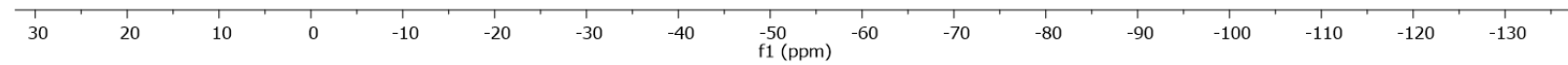

Figure S6. Compatibility experiments of organoboron nucleophiles with DFAF after $1 \mathrm{~h}$ at room temperature in THF as shown by ${ }^{19} \mathrm{~F}$ NMR spectroscopy. NMR spectrum also contains trifluoromethoxybenzene and 4-fluorotoluene as internal standards. Referenced to 4-fluorotoluene as internal standard (-119.85 ppm).

\section{Procedure and spectral data for stoichiometric decarbonylation studies [Figures 1 and 2 in manuscript]}

A. Stoichiometric reaction of trifluoroacetic anhydride with Pd/SPhos. A solution of trifluoroacetic anhydride ( $0.4 \mathrm{~mL}, 0.04 \mathrm{mmol}, 0.1 \mathrm{M}, 4$ equiv) in anhydrous tetrahydrofuran was prepared. To this was added a THFsolution of 4-fluorotoluene ( $0.4 \mathrm{~mL}, 0.04 \mathrm{mmol}, 0.1 \mathrm{M}, 4.0$ equiv). $\mathrm{Pd}\left[\mathrm{P}(\mathrm{o}-\mathrm{Tol})_{3}\right]_{2}(21.3 \mathrm{mg}, 0.03 \mathrm{mmol}, 3$ equiv) and SPhos (12.3 mg, $0.03 \mathrm{mmol}$, 3 equiv) were suspended in anhydrous THF (0.3 mL), and this mixture was stirred vigorously for $5 \mathrm{~min}$. To the THF-suspension of Pd and SPhos was added $0.6 \mathrm{~mL}$ of the anhydride solution to generate a solution with $0.9 \mathrm{~mL}$ of total volume. The remaining $0.2 \mathrm{~mL}$ of anhydride solution was diluted and used as a ${ }^{19} \mathrm{~F}$ NMR reference (spectrum A in Figure S7). The reaction mixture was stirred briefly to ensure homogeneity and was then portioned evenly into three vials $\left(i\right.$, ii, iii). $A{ }^{19} \mathrm{~F}$ NMR spectrum of sample $i$ was acquired after $15 \mathrm{~min}$ and showed $98 \%$ yield of $\mathrm{I}_{-} \mathrm{COCF}_{3}$ (Figure S7, B). A ${ }^{19} \mathrm{~F}$ NMR spectrum of sample ii was acquired after $4 \mathrm{~h}$ (Figure S7, C) and lacked the minor TFAAn peak still observed in the spectrum

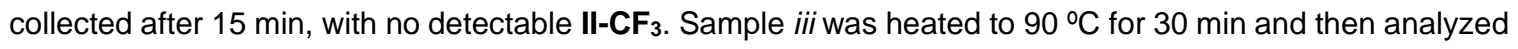
by ${ }^{19} \mathrm{~F}$ NMR spectroscopy, which showed the formation of $\mathrm{II}_{-\mathrm{CF}_{3}}$ in $90 \%$ yield (Figure S7, D). The associated 
spectra are shown in Figure S7. The complexes were identified by ${ }^{19} \mathrm{~F}$ NMR spectroscopy based on the diagnostic locations of the observed peaks, which are in excellent agreement with our previous report ${ }^{1 \mathrm{a}}$ of an analogous transformation at (RuPhos) $\mathrm{Pd}(0)$.

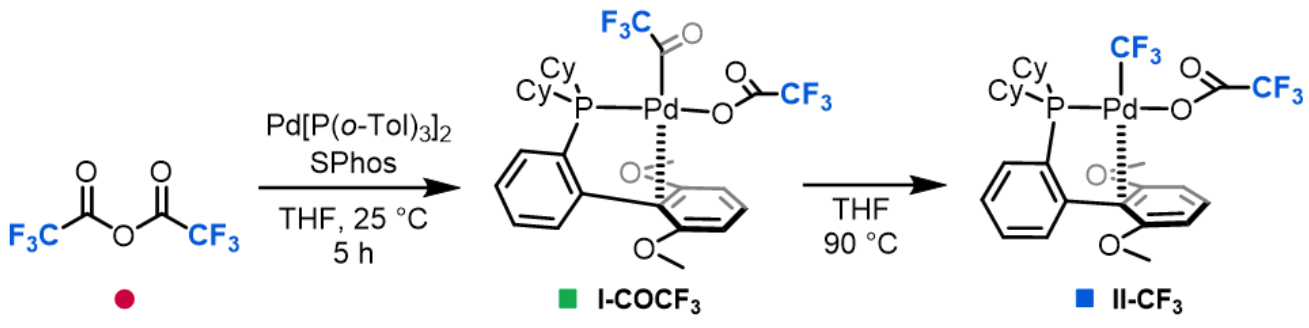

A. TFAAn

B. $0.25 \mathrm{~h}, 25^{\circ} \mathrm{C}$

B.

C. $4 \mathrm{~h}, 25^{\circ} \mathrm{C}$

D. $0.5 \mathrm{~h}, 90^{\circ} \mathrm{C}$

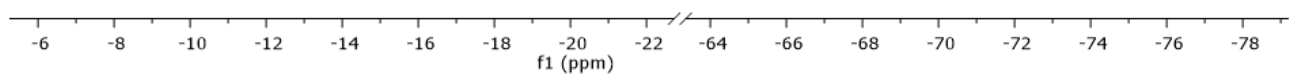

Figure S7. ${ }^{19} \mathrm{~F}$ NMR spectra associated with oxidative addition and carbonyl de-insertion of trifluoroacetic anhydride at Pd[P(o-Tol) $]_{2} / \mathrm{SPhos}$. (A) TFAAn; (B) $0.25 \mathrm{~h}, \mathrm{RT}$; (C) $4 \mathrm{~h}, \mathrm{RT}$; and (D) $0.5 \mathrm{~h}, 90 \stackrel{\circ}{\circ} \mathrm{C}$. Referenced to 4 -fluorotoluene as internal standard (-119.85 ppm).

In situ NMR characterization:

TFAAn: ${ }^{19} \mathrm{~F}$ NMR $(376 \mathrm{MHz}) \delta-76.73(\mathrm{~s}, 6 \mathrm{~F})$

I-COCF 3 : ${ }^{19} \mathrm{~F}$ NMR $(376 \mathrm{MHz}) \delta-73.94(\mathrm{~s}, 3 \mathrm{~F}),-75.61$ (s, 3F).

II-CF $3:{ }^{19} \mathrm{~F}$ NMR $(376 \mathrm{MHz}) \delta-11.60(\mathrm{bs}, 3 \mathrm{~F}),-75.69$ (s, 3F). 
B. Stoichiometric decarbonylation of difluoroacetic anhydride with Pd/SPhos. A solution of difluoroacetic anhydride $(0.4 \mathrm{~mL}, 0.04 \mathrm{mmol}, 0.1 \mathrm{M}, 4$ equiv) in anhydrous tetrahydrofuran was prepared. To this was added a THF solution of 4 -fluorotoluene $\left(0.4 \mathrm{~mL}, 0.04 \mathrm{mmol}, 0.1 \mathrm{M}, 4.0\right.$ equiv). $\mathrm{Pd}\left[\mathrm{P}(\mathrm{o}-\mathrm{Tol})_{3}\right]_{2}(21.3 \mathrm{mg}, 0.03 \mathrm{mmol}$, 3 equiv) and SPhos (12.3 mg, $0.03 \mathrm{mmol}, 3$ equiv) were suspended in anhydrous THF (0.3 mL), and this mixture stirred vigorously for $5 \mathrm{~min}$. To the THF suspension of $\mathrm{Pd}$ and SPhos was added $0.6 \mathrm{~mL}$ of the anhydride solution. The remaining $0.2 \mathrm{~mL}$ of anhydride solution was diluted and used as a ${ }^{19} \mathrm{~F}$ NMR reference (spectrum A in Figure S8). The Pd solution containing internal standard, ligand, and anhydride was stirred briefly to ensure homogeneity and then portioned evenly into three vials (i, ii, iii). A ${ }^{19} \mathrm{~F}$ NMR spectrum was acquired of sample $i$ after $15 \mathrm{~min}$ at room temperature and showed $85 \%$ yield of $\mathbf{I}-\mathbf{C O C H F}_{2}$ and $13 \%$ yield of

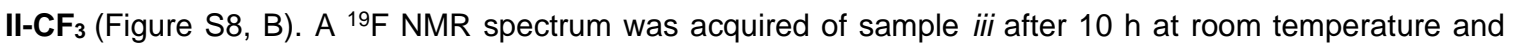
showed $91 \%$ yield of $\mathrm{II}_{-} \mathrm{CHF}_{2}$ and $6 \%$ remaining $\mathrm{I}-\mathrm{COCHF}_{2}$ (Figure S8, C).

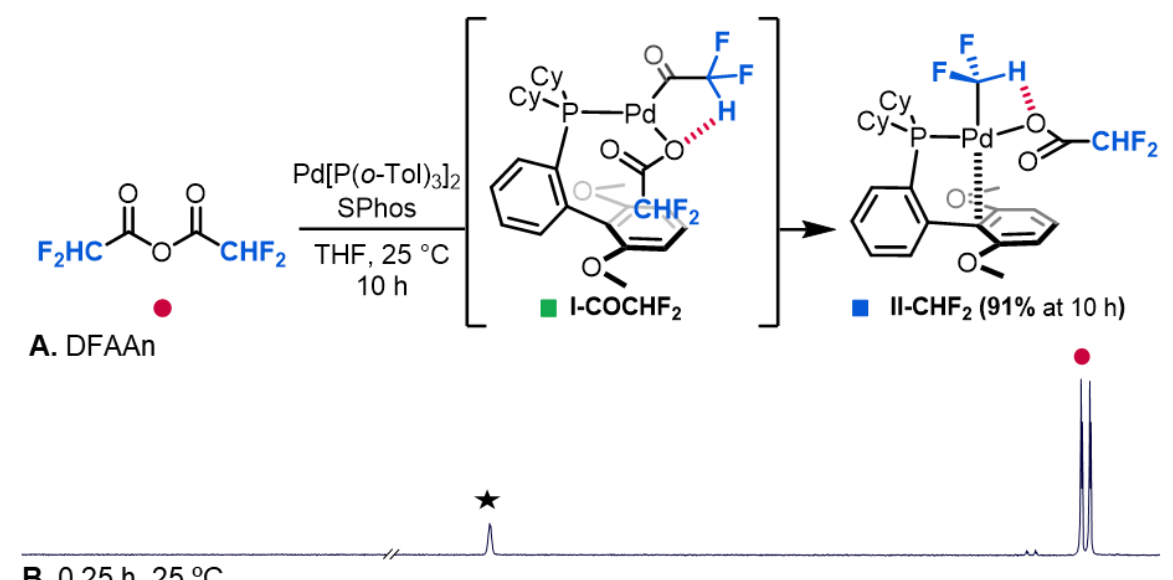

B. $0.25 \mathrm{~h}, 25^{\circ} \mathrm{C}$

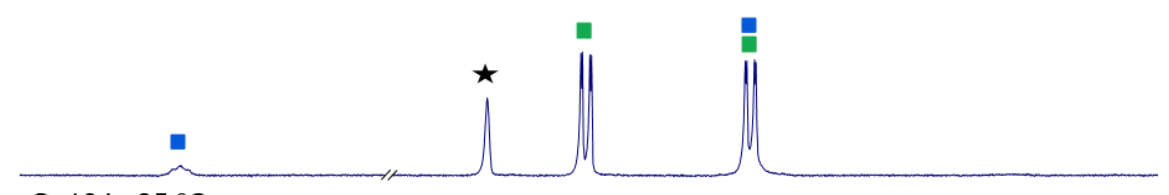

C. $10 \mathrm{~h}, 25^{\circ} \mathrm{C}$

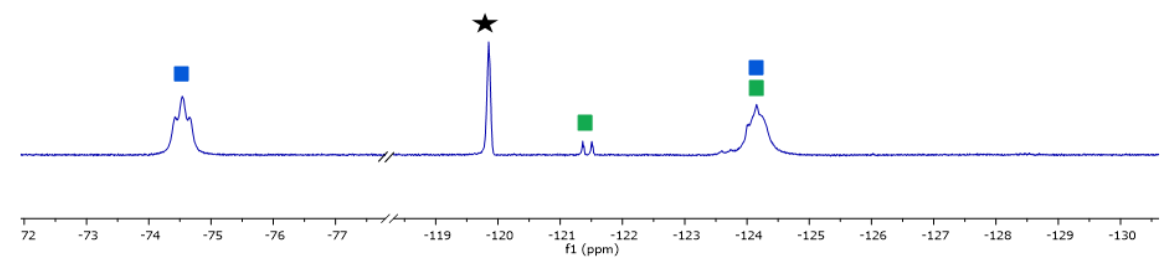

Figure S8. ${ }^{19} \mathrm{~F}$ NMR spectra associated with oxidative addition and decarbonylation of difluoroacetic anhydride at $\mathrm{Pd}\left[\mathrm{P}(\mathrm{o}-\mathrm{Tol})_{3}\right]_{2} / \mathrm{SPhos}$ in THF. (A) DFAAn; (B) $0.25 \mathrm{~h}, \mathrm{RT}$; and (C) $10 \mathrm{~h}$, RT. Black star represents 4-fluorotoluene internal standard (-119.85 ppm).

The spectra show a dramatically lower barrier for carbonyl de-insertion at I-COCHF 2 compared to I-COCF 3 . After $10 \mathrm{~h}$ stirring at room temperature, $\mathrm{II}_{-\mathrm{CHF}_{2}}$ is obtained in $91 \%$ yield with $6 \%$ acyl complex remaining based on the ${ }^{19} \mathrm{~F}$ NMR spectrum. This is in sharp contrast to the temperature requirement for carbonyl de-insertion of $\mathbf{I}_{-} \mathrm{COCF}_{3}$. Notably, 
reacting $\mathrm{Pd}\left[\mathrm{P}(\mathrm{O}-\mathrm{Tol})_{3}\right]_{2} / \mathrm{SPhos}$ with difluoroacetic anhydride in an NMR tube without stirring led to significantly lower rates of carbonyl de-insertion.

C. Stoichiometric reaction of pentafluoropropionic anhydride (PFPAn) with Pd/SPhos. A THF-solution of pentafluoropropionic anhydride $(0.4 \mathrm{~mL}, 0.05 \mathrm{mmol}, 0.125 \mathrm{M}, 5$ equiv) was prepared. To this was added a THF-solution of 4-fluorotoluene $\left(0.4 \mathrm{~mL}, 0.04 \mathrm{mmol}, 0.1 \mathrm{M}, 4\right.$ equiv). $\mathrm{Pd}\left[\mathrm{P}(0-\mathrm{Tol})_{3}\right]_{2}(21.3 \mathrm{mg}, 0.03 \mathrm{mmol}, 3$ equiv) and SPhos (12.3 mg, $0.03 \mathrm{mmol}, 3$ equiv) were weighed in a separate 4-mL vial with a stirbar, $0.6 \mathrm{~mL}$ THF were added, and the mixture was stirred. To the stirred mixture of Pd and SPhos in THF was added 0.6 $\mathrm{mL}$ of the anhydride/4-fluorotoluene solution to generate a solution with a total volume of $1.2 \mathrm{~mL}$. The remaining $0.2 \mathrm{~mL}$ of anhydride/4-fluorotoluene solution was diluted with THF and used as a ${ }^{19} \mathrm{~F}$ NMR reference (spectrum A in Figure S9). The reaction mixture was stirred briefly to ensure homogeneity and was then portioned evenly $(0.4 \mathrm{~mL})$ into three vials $(i, i i, i i)$. A ${ }^{19} \mathrm{~F}$ NMR spectrum of sample $i$ was acquired after $0.25 \mathrm{~h}$ and shows conversion of PFPAn to I-COCF $\mathbf{C F}_{3}$ (Figure S9, B). Sample ii was also analyzed by ${ }^{31} \mathrm{P}$ NMR spectroscopy (Figure S10, A). A ${ }^{19} \mathrm{~F}$ NMR spectrum of sample ii was acquired after $4 \mathrm{~h}$ and showed no significant change to the ${ }^{19} \mathrm{~F}$ NMR spectrum obtained from sample / (Figure S9, C). Sample iii was heated to $90{ }^{\circ} \mathrm{C}$ for $30 \mathrm{~min}$ and then analyzed by ${ }^{19} \mathrm{~F}$ NMR spectroscopy (Figure S9, D) and ${ }^{31} \mathrm{P}$ spectroscopy (Figure S10, B), which support the quantitative conversion of $\mathbf{I}-\mathbf{C O C F}_{\mathbf{2}} \mathbf{C F}_{\mathbf{3}}$ to $\mathbf{I I -} \mathbf{C F}_{\mathbf{2}} \mathbf{C F}_{\mathbf{3}}$. The complexes were characterized in situ by ${ }^{19} \mathrm{~F}$ NMR and ${ }^{31} \mathrm{P}$ NMR spectroscopy based on the diagnostic locations of the observed peaks $^{1 \mathrm{a}}$. 

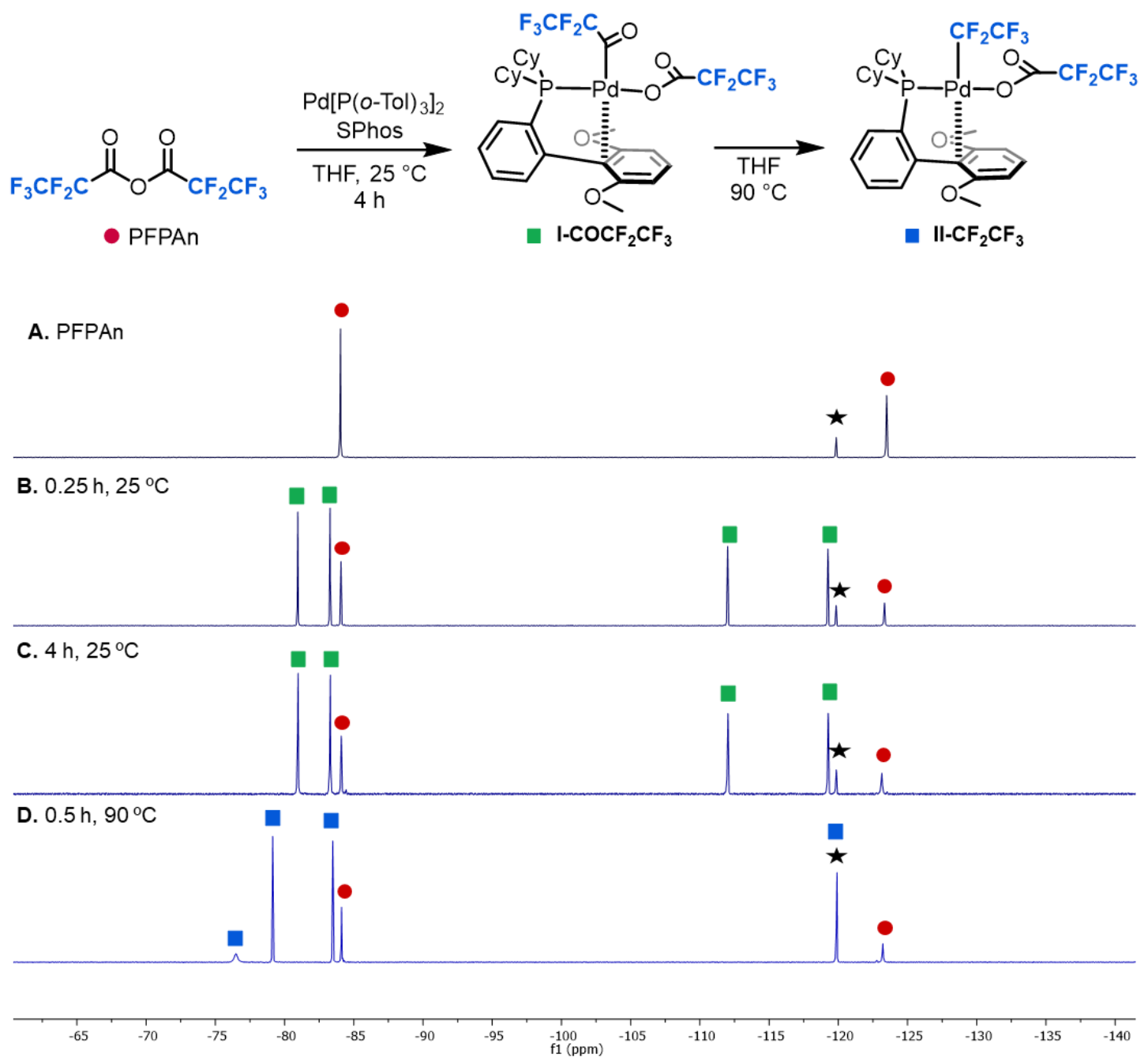

Figure S9. ${ }^{19} \mathrm{~F}$ NMR spectra associated with oxidative addition and decarbonylation of pentafluoropropionic anhydride at Pd[P(o-Tol $\left.)_{3}\right]_{2} /$ SPhos in THF. (A) PFPAn; (B) $15 \mathrm{~min}, \mathrm{RT}$; (C) $4 \mathrm{~h}, \mathrm{RT}$; and (D) $0.5 \mathrm{~h}, 90^{\circ} \mathrm{C}$. Black star represents 4-fluorotoluene internal standard (-119.85 ppm). 


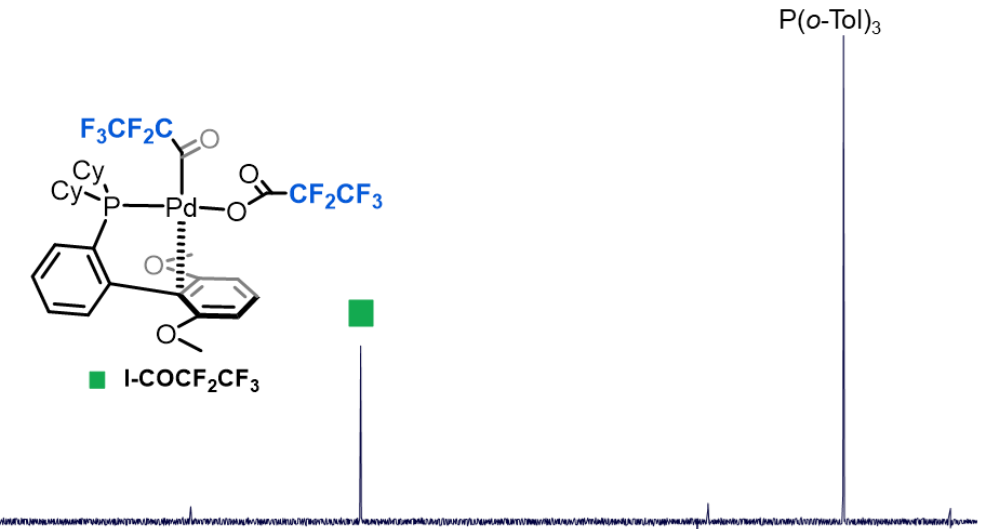

B. $0.5 \mathrm{~h}, 90^{\circ} \mathrm{C}$
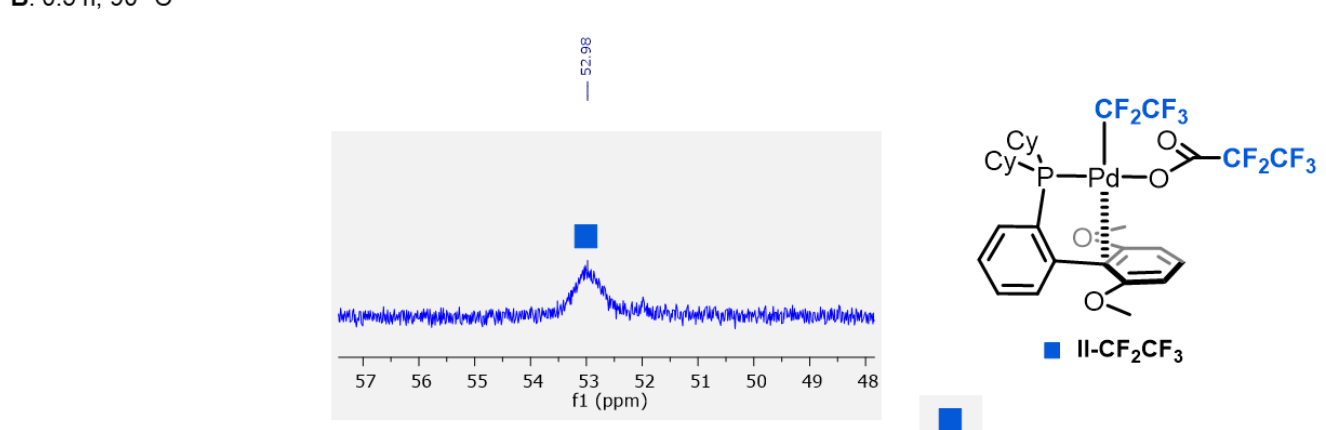

$\mathrm{P}(\mathrm{o}-\mathrm{Tol})_{3}$

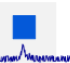

Figure S10. ${ }^{31} \mathrm{P}$ NMR spectra associated with oxidative addition and decarbonylation of pentafluoropropionic anhydride at $\mathrm{Pd}\left[\mathrm{P}(\mathrm{o}-\mathrm{Tol})_{3}\right]_{2} / \mathrm{SPhos}$ in THF. (A) $0.25 \mathrm{~h}, \mathrm{RT}$; (B) $0.5 \mathrm{~h}, 90^{\circ} \mathrm{C}$.

In situ NMR characterization:

PFPAn: ${ }^{19} \mathrm{~F}$ NMR (376 MHz) $\delta-84.07$ (s, 6F), -123.33 (s, 4F).

I-COCF ${ }_{2} \mathrm{CF}_{3}:{ }^{19} \mathrm{~F}$ NMR $(376 \mathrm{MHz}) \delta-80.96(\mathrm{~s}, 3 \mathrm{~F}),-83.28(\mathrm{~s}, 3 \mathrm{~F}),-112.00(\mathrm{~s}, 2 \mathrm{~F}),-119.25(\mathrm{~s}, 2 \mathrm{~F}) .{ }^{31} \mathrm{P}$ NMR $(162 \mathrm{MHz}) \delta 46.04$ (s, 1P).

II-CF $\mathrm{CF}_{3}:{ }^{19} \mathrm{~F}$ NMR (376 MHz) $\delta-76.49$ (bs, 2F), -79.14 (s, 3F), $-88.48(\mathrm{~s}, 3 \mathrm{~F}),-119.91^{*}(\mathrm{~s}, 2 \mathrm{~F}) .{ }^{31} \mathrm{P}$ NMR (162 $\mathrm{MHz}) \delta 52.98$ (bs, 1P).

The data in Figures S9 and S10 show that the reactivity of PFPAn nearly identical to that observed for TFAAn (i.e. fast oxidative addition and slow carbonyl de-insertion at room temperature). Notably, both TFAAn and PFPAn lack the acidic hydrogen found in DFAAn and thus require high temperatures for carbonyl de-insertion. 
V. Synthesis, isolation, and spectral data for complex II-CHF 2 .

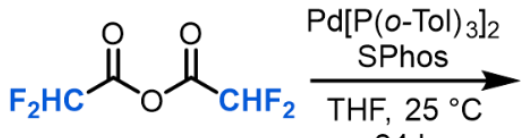

$24 \mathrm{~h}$
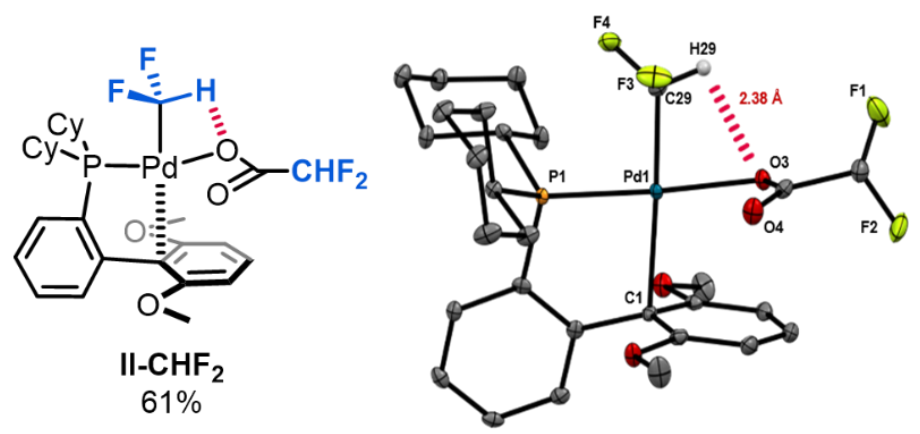

Synthesis of complex II-CHF . A $20 \mathrm{~mL}$ vial equipped with a stir bar was charged with $\mathrm{Pd}\left[\mathrm{P}(\mathrm{o}-\mathrm{Tol})_{3}\right]_{2}(340 \mathrm{mg}, 0.48$ mmol, 1.0 equiv), SPhos (195 mg, $0.48 \mathrm{mmol}, 1.0$ equiv), and THF (4 mL). To this stirring suspension was added difluoroacetic anhydride $(87 \mathrm{mg}, 0.5 \mathrm{mmol}, 1.05$ equiv). The reaction was stirred for $18 \mathrm{~h}$ at room temperature, then concentrated to ca. $1 \mathrm{~mL}$ in vacuo to yield a dark yellow oil. The oil was loaded onto a $2 \mathrm{~cm}$ tall celite plug in a disposable fritted funnel and eluted with THF (8-10 mL). The yellow filtrate was concentrated in vacuo, yielding a yellow, oily residue. After addition of pentanes, a pale-yellow precipitate formed. The yellow suspension was loaded onto a $2 \mathrm{~cm}$ tall celite plug in a disposable fritted funnel, and the solid was washed with diisopropyl ether $(10 \mathrm{~mL})$, then a minimal amount of cold anhydrous $\mathrm{Et}_{2} \mathrm{O}$. The pale solid was eluted with tetrahydrofuran, and the resultant yellow filtrate was concentrated in vacuo, yielding II-CHF 2 as an off-white solid (195 mg, $0.29 \mathrm{mmol}, 61 \%$ yield) containing about 0.2 equiv of tetrahydrofuran, as determined by ${ }^{1} \mathrm{H}$ NMR spectroscopy. ${ }^{19} \mathrm{~F}$ NMR $\left(470 \mathrm{MHz}\right.$, Methylene Chloride- $\left.\mathrm{d}_{2}\right) \delta-75.29(\mathrm{t}, J$ $=46.1 \mathrm{~Hz}),-124.38\left(\mathrm{~d}, J=57.0 \mathrm{~Hz}\right.$ ). ${ }^{31} \mathrm{P}$ NMR $(202 \mathrm{MHz}$, Methylene Chloride-d 2$) \delta 46.05$ (t, $\left.J=37.6 \mathrm{~Hz}\right) .{ }^{1} \mathrm{H} \mathrm{NMR}$ (700 MHz, Methylene Chloride- $d_{2}$ ) $\delta 7.73(\mathrm{t}, J=7.1 \mathrm{~Hz}, 1 \mathrm{H}$ ), 7.58-7.38 (multiple peaks, 3H), 6.78 (ddd, $J=7.6,3.0,1.4$ $\mathrm{Hz}, 1 \mathrm{H}), 6.57(\mathrm{~d}, J=8.5 \mathrm{~Hz}, 2 \mathrm{H}), 6.26(\mathrm{td}, J=53.0,5.1 \mathrm{~Hz}, 1 \mathrm{H}), 5.60$ (t, $J=55.7 \mathrm{~Hz}, 1 \mathrm{H}), 3.80$ (s, 6H), 2.33-2.23 (m, 2H), $2.13(\mathrm{~d}, \mathrm{~J}=8.1 \mathrm{~Hz}, 2 \mathrm{H}$ ), 1.95-1.76 (multiple peaks, $6 \mathrm{H}$ ), 1.74-1.55 (multiple peaks, $4 \mathrm{H}$ ), 1.41-1.16 (multiple peaks, 6H). ${ }^{13} \mathrm{C}$ NMR (176 MHz, Methylene Chloride-d 2 ) $\delta 167.24(\mathrm{t}, J=24.4 \mathrm{~Hz}), 161.94,144.06(\mathrm{~d}, J=17.5 \mathrm{~Hz}), 137.15$, 135.32 (d, $J=42.3 \mathrm{~Hz}$ ), 132.58, 132.08, 132.01 (d, J = 3.0 Hz), 127.49 (d, J = 6.0 Hz), 119.50 (td, J=314.1, $14.1 \mathrm{~Hz}$ ), 110.20 (t, $J=249.6 \mathrm{~Hz}$ ), 56.38, 35.85 (d, $J=26.9 \mathrm{~Hz}$ ), 29.50, 29.16 (d, $J=1.8 \mathrm{~Hz}), 27.87$ (dd, $J=29.1,12.8 \mathrm{~Hz}$ ), 26.62 (d, $J=1.7 \mathrm{~Hz}$ ). HRMS (ESI+) calcd. for $\mathrm{C}_{29} \mathrm{H}_{37} \mathrm{~F}_{4} \mathrm{O}_{4} \mathrm{PPd}[\mathrm{M}+\mathrm{H}] \mathrm{m} / \mathrm{z}$ 662.1400. Parent - OCOCHF $2 \mathrm{~m} / z$ 567.1456. Found 567.1470. X-ray quality crystals of II- $\mathrm{CHF}_{2}$ were obtained by vapor diffusion of $\mathrm{Et}_{2} \mathrm{O} /$ pentanes into a THF solution of $\mathrm{II}_{-} \mathrm{CHF}_{2}$ at room temperature. An ORTEP diagram of $\mathrm{II}_{-} \mathbf{C H F}_{2}$ is shown with select hydrogen atoms are omitted for clarity. Selected bond lengths (Å) and angle (deg): O3-Pd1 2.11, O4-Pd1 3.09, C29-Pd1 1.99, C1-Pd1 2.46; H29--O3 2.38; C29-Pd1-O3 81.7, C29-H29---O3 96.9. See section XVI for X-ray crystal structure data of II-CHF 2 . 

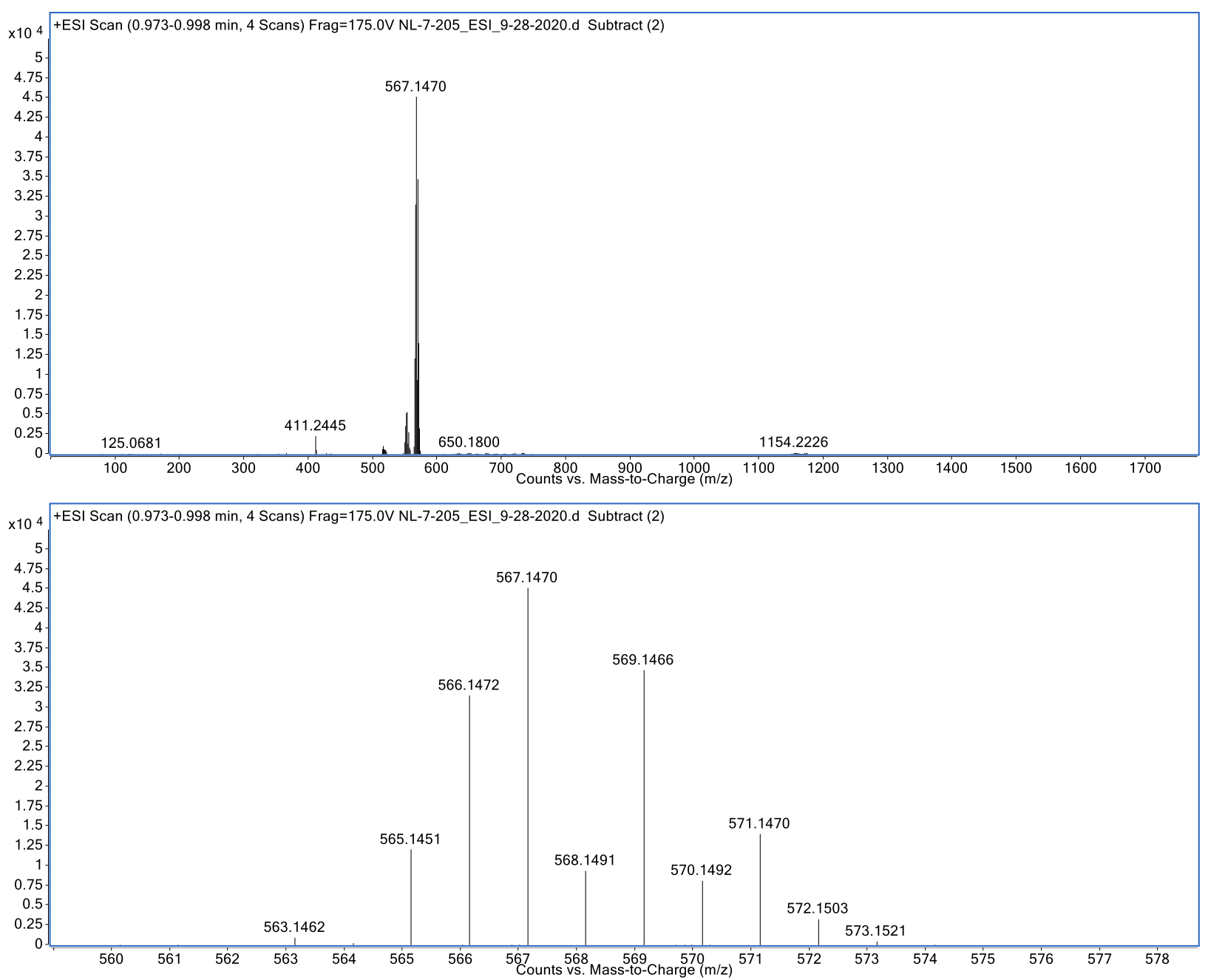

Figure S11. ESI+ Scans for HRMS analysis of II- $\mathrm{CHF}_{2}-\mathrm{OCOCHF}_{2}$.

\section{Procedure and spectral data for stoichiometric transmetalation studies [Figures 6 and 7 in manuscript]}

General procedure for the stoichiometric transmetalation of complex II-CHF 2 with various aryl boron-based nucleophiles. A $4 \mathrm{~mL}$ vial equipped with a stir bar was charged with II-CHF 2 (19.9 mg, 0.03 mmol, 3.0 equiv) and anhydrous tetrahydrofuran $(0.6 \mathrm{~mL})$. To the stirred solution, a THF solution of 4-fluorotoluene $(0.3 \mathrm{~mL}, 0.1 \mathrm{M}, 0.03$ mmol, 3 equiv) was added. The solution was divided into three separate solutions ( $0.3 \mathrm{~mL}$ each), each in a $4 \mathrm{~mL}$ vial equipped with a stir bar. The first solution was transferred to a screw-cap NMR tube and used for ${ }^{19} \mathrm{~F}$ NMR analysis ( $t$ $=0)$. To each of the remaining solutions was added one of the following nucleophiles: 4-phenyl boronic acid 1a, 4-(5,5dimethyl-1,3,2-dioxaborinan-2-yl)benzonitrile, 1 b $(2.2 \mathrm{mg}, 0.01 \mathrm{mmol}, 1.0$ equiv) or 4-(4,4,5,5-tetramethyl-1,3,2dioxaborolan-2-yl)benzonitrile, $1 \mathrm{c}(2.3 \mathrm{mg}, 0.01 \mathrm{mmol}, 1.0$ equiv). Each solution was stirred for $0.25 \mathrm{~h}$, transferred to a screw cap NMR tube, and analyzed via ${ }^{19} \mathrm{~F}$ NMR spectroscopy. The spectra are shown in Figure S12. After $0.25 \mathrm{~h}$, $40 \%$ of product 1 was observed with the reaction with $45 \%$ of II-CHF 2 remaining. Trace product 1 was observed using neopentyl boronate ester $\mathbf{1 b}$, whereas no detectable product was observed in the reaction between $\mathrm{II}_{\mathbf{C}} \mathbf{C H F}_{\mathbf{2}}$ and pinacol 
boronate ester 1c. Notably, the Pd-aryl intermediate is not observed, only the organic product 1 was observed at $114.2 \mathrm{ppm}(\mathrm{d}, J=56.4 \mathrm{~Hz})$ by ${ }^{19} \mathrm{~F}$ NMR spectroscopy as result of transmetalation and reductive elimination at room temperature.
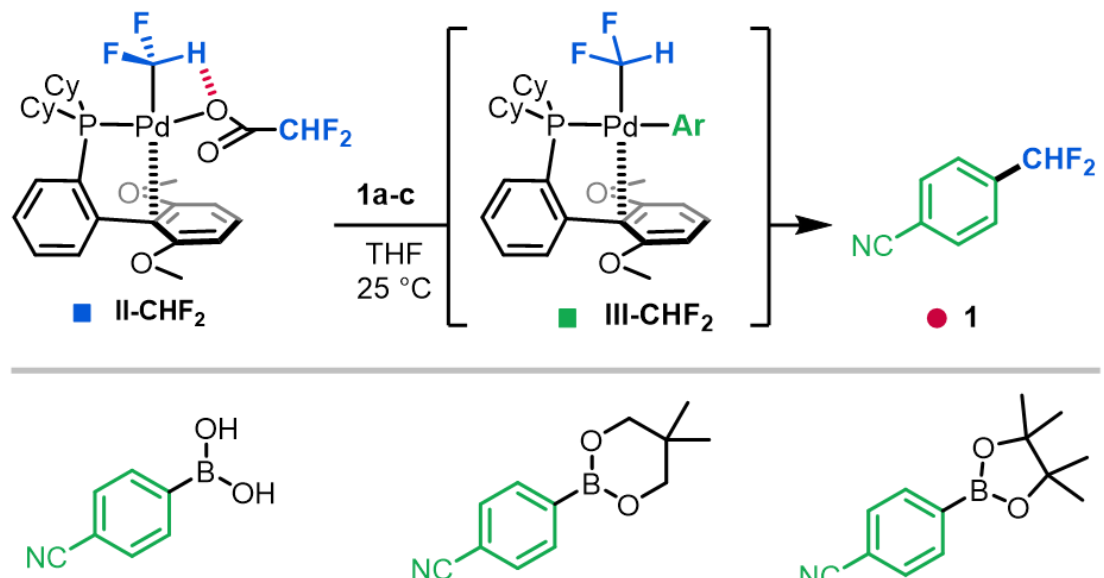

$1 \mathrm{a}$

$40 \% 1$ observed

$45 \%$ II-CHF 2 remains

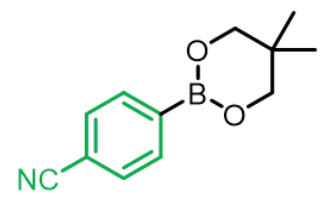

$1 \mathrm{~b}$

trace 1 observed

99\% II- $\mathrm{CHF}_{2}$ remains

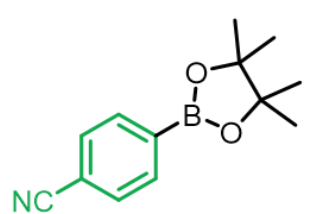

1c

no reaction

$>99 \% \mathrm{II}_{-} \mathrm{CHF}_{2}$ remains

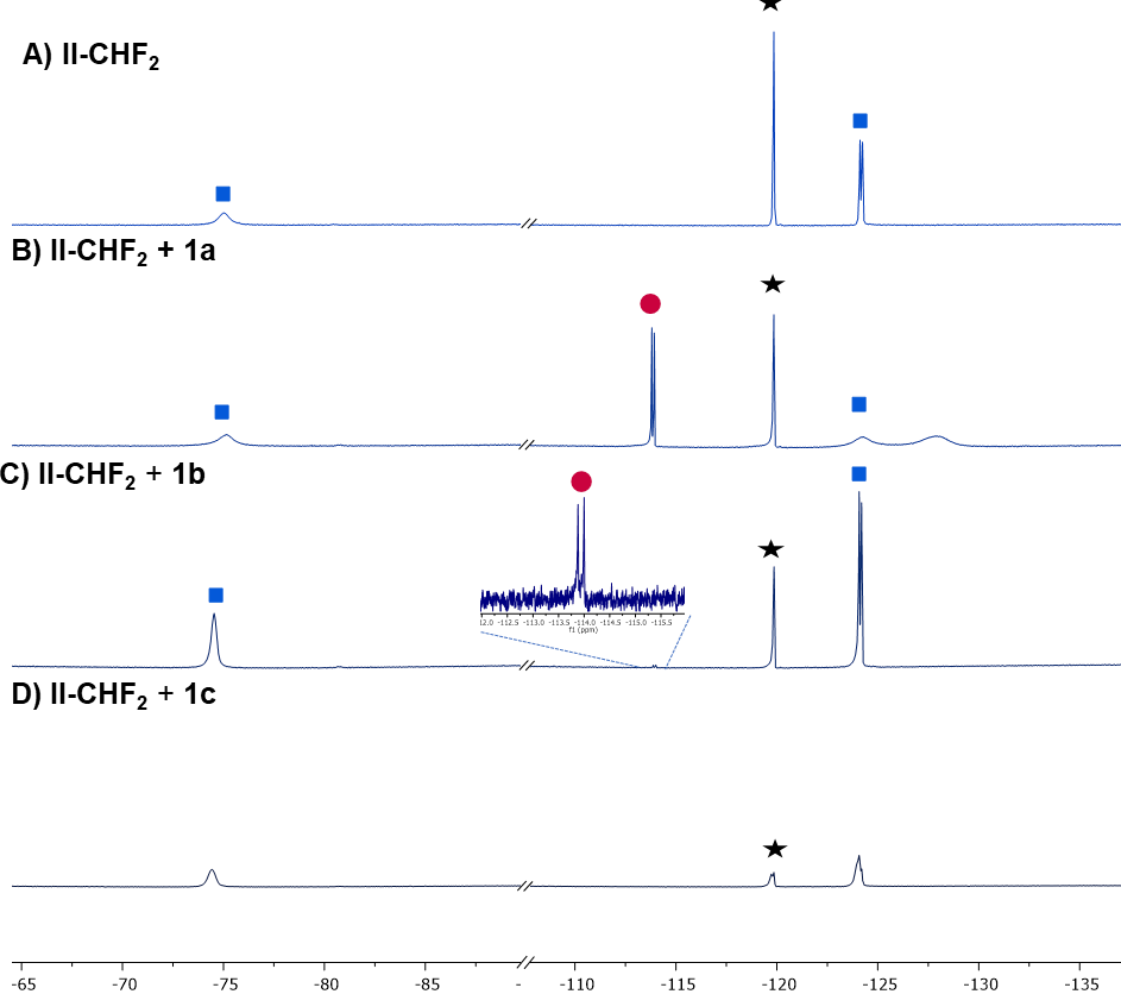

Figure S12. ${ }^{19} \mathrm{~F}$ NMR spectra associated with transmetalation of II-CHF $\mathbf{2}$ with (B) boronic acid $\mathbf{1 a}$, (C) boronic ester $\mathbf{1 b}$, and (D) boronic ester 1C. 
General procedure for the stoichiometric transmetalation at II-CHF 2 with added NMe 4 . A 4 mL vial equipped with a stir bar was charged with II-CHF $2(6.6 \mathrm{mg}, 0.01 \mathrm{mmol}, 0.5$ equiv) and anhydrous tetrahydrofuran (0.2 $\mathrm{mL})$. To this was added a THF solution of 4 -fluorotoluene $\left(0.1 \mathrm{~mL}, 0.1 \mathrm{M}, 0.01 \mathrm{mmol}, 1.0\right.$ equiv) then solid $\mathrm{NMe} 4 \mathrm{~F} \cdot{ }^{t} \mathrm{AmylOH}(3.6$ $\mathrm{mg}, 0.02 \mathrm{mmol}, 2.0$ equiv). ${ }^{1 \mathrm{~b}}$ The suspension was stirred for $0.5 \mathrm{~h}$, filtered through a syringe filter, then transferred to a screw cap NMR tube, sealed with a Teflon-lined cap, and analyzed by ${ }^{19} \mathrm{~F}$ NMR spectroscopy. The formation of a distinct $\mathrm{Pd}-\mathrm{F}$ intermediate in $12 \%$ yield is observed, based on a diagnostic resonance at $-349.5 \mathrm{ppm} .^{2} \mathrm{Moreover}$, several new peaks appear in the Pd-CHF 2 region (-86 to $-93 \mathrm{ppm})$. Upon addition of substrate $1 \mathbf{b}(2.2 \mathrm{mg}, 0.01 \mathrm{mmol}$, 1.0 equiv) to this sample, the Pd-F intermediate disappears, and organic product 1 was formed in $27 \%$ yield (shown below in Figure S13).
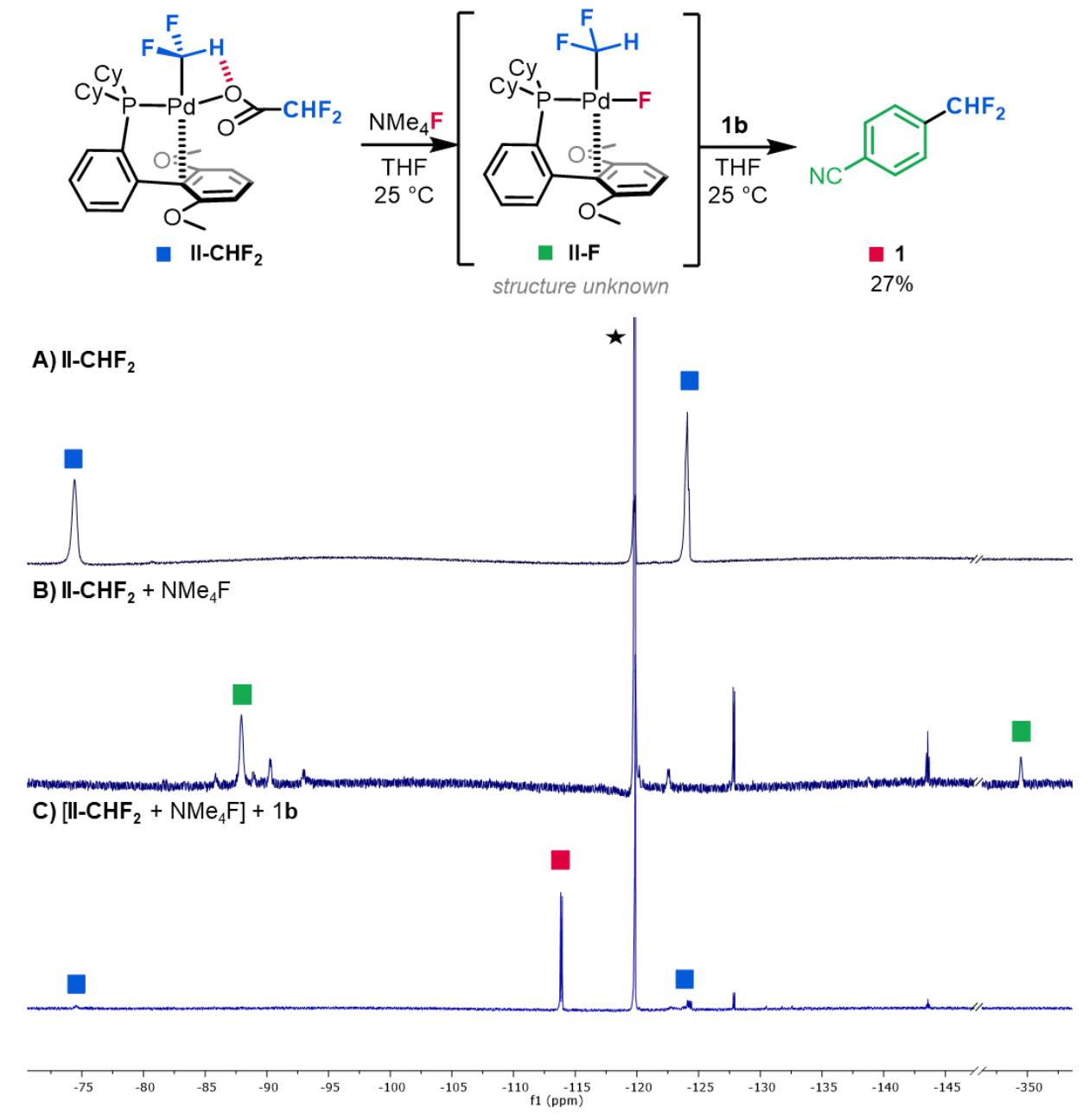

Figure S13. ${ }^{19} \mathrm{~F}$ NMR spectra associated with fluoride-aided transmetalation of II-CHF $\mathbf{2}$ with substrate $\mathbf{1 b}$. 

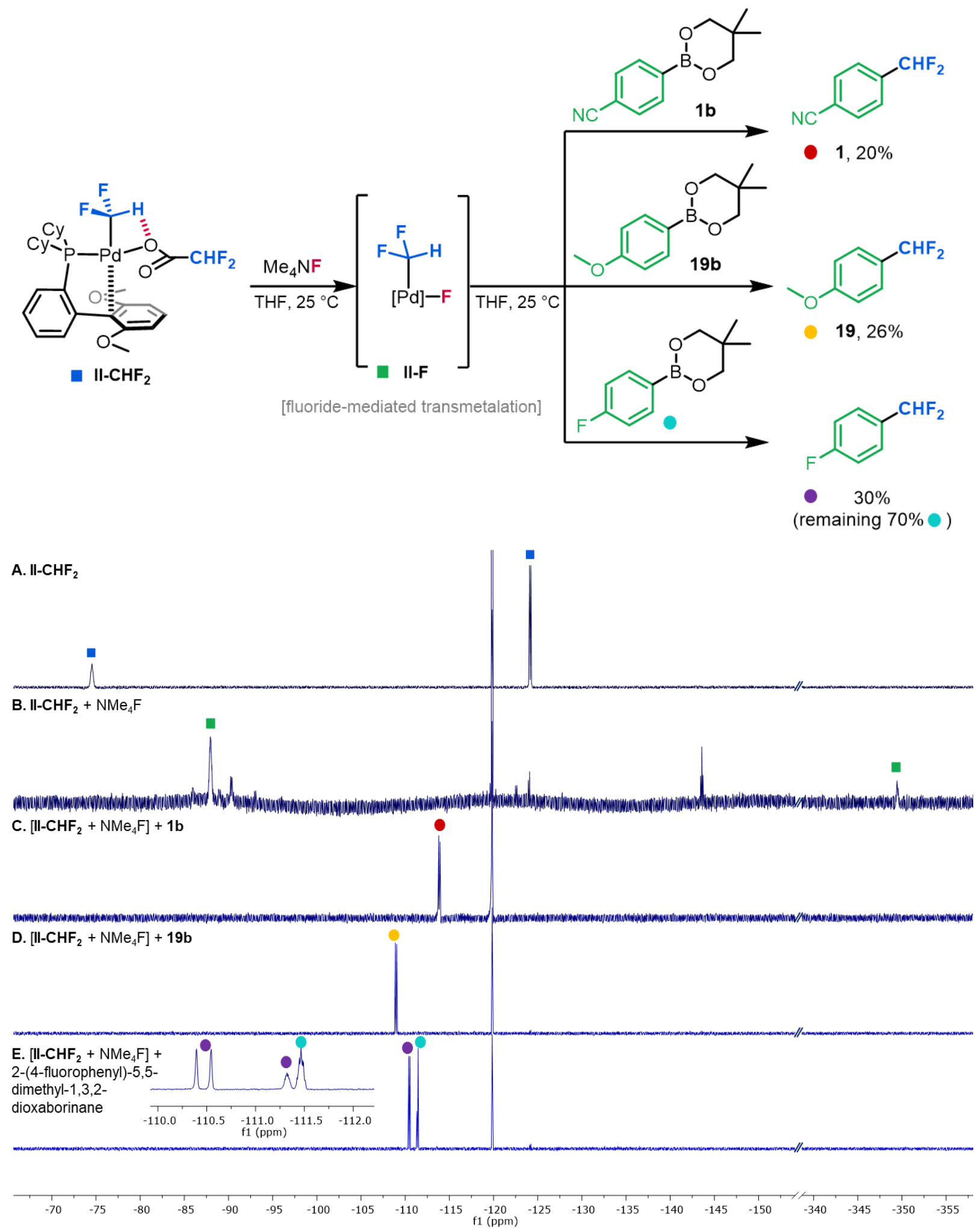

Figure S14. ${ }^{19} \mathrm{~F}$ NMR spectra associated with fluoride-aided transmetalation of II-CHF 2 with substrates $\mathbf{1 b}, \mathbf{1 9 b}$, and 20b. 
Transmetalation with 19b. The general procedure was followed resulting in $4 \%$ of $\mathrm{Pd}-\mathrm{F}$ observed by ${ }^{19} \mathrm{~F}$ NMR with 4-fluorotoluene internal standard. After addition of substrate $19 \mathrm{~b}$ ( $2.2 \mathrm{mg}, 0.01 \mathrm{mmol}, 1.0$ equiv) to this sample, the $\mathrm{Pd}-\mathrm{F}$ signal was consumed and organic product 19 was formed in $26 \%$ yield by ${ }^{19} \mathrm{~F}$ NMR (Figure S14, D). Characterized product 19 in situ: ${ }^{19} \mathrm{~F}$ NMR (376 MHz) $\delta-108.96$ (d, $\left.J=56.7 \mathrm{~Hz}, 2 \mathrm{~F}\right)$.

Transmetalation with 2-(4-fluorophenyl)-5,5-dimethyl-1,3,2-dioxaborinane. The general procedure was followed resulting in $4 \%$ of $\mathrm{Pd}-\mathrm{F}$ observed by ${ }^{19} \mathrm{~F}$ NMR with 4-fluorotoluene internal standard. After addition of 2-(4-fluorophenyl)5,5-dimethyl-1,3,2-dioxaborinane $(2.0 \mathrm{mg}, 0.01 \mathrm{mmol}, 1.0$ equiv) to this sample, the $\mathrm{Pd}-\mathrm{F}$ signal was consumed and 1-(difluoromethyl)-4-fluorobenzene was formed in $30 \%$ yield by ${ }^{19} \mathrm{~F}$ NMR. The remaining mass balance is $2-(4-$ fluorophenyl)-5,5-dimethyl-1,3,2-dioxaborinane (70\%) observed at $-111.47 \mathrm{ppm}$ in the ${ }^{19} \mathrm{~F}$ NMR (Figure S14, E). Characterized 1-(difluoromethyl)-4-fluorobenzene in situ: ${ }^{19} \mathrm{~F}$ NMR (376 MHz) $\delta-110.47(\mathrm{~d}, \mathrm{~J}=56.4 \mathrm{~Hz}, 2 \mathrm{~F}),-111.35$ $(\mathrm{m}, 1 \mathrm{~F})$.

VII. Procedure for the synthesis of aryl neopentyl boronate esters

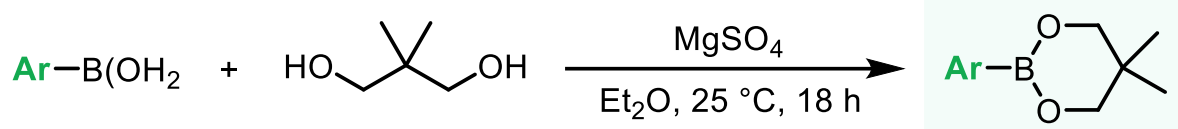

General procedure for the synthesis of aryl neopentyl boronate esters from aryl boronic acids (Method A) ${ }^{3}$ : Under ambient conditions, the respective aryl boronic acid (2.0 mmol, 1.0 equiv), 2,2-dimethyl-1,3-propanediol (208 $\mathrm{mg}, 2.0 \mathrm{mmol}, 1.0$ equiv), and anhydrous magnesium sulfate (240 mg, $2.0 \mathrm{mmol}, 1.0$ equiv) were weighed into a 20 $\mathrm{mL}$ vial. The vial was equipped with a magnetic stirbar, and $\mathrm{Et}_{2} \mathrm{O}(10 \mathrm{~mL})$ was added. The vial was sealed with a Teflonlined screw cap, and the resulting suspension was stirred under ambient conditions for $18 \mathrm{~h}$. The reaction mixture was then filtered through a $3 \mathrm{~cm} \times 3 \mathrm{~cm} \times 3 \mathrm{~cm}$ celite plug set with $\mathrm{Et}_{2} \mathrm{O}$. The celite plug was washed with $\mathrm{Et}_{2} \mathrm{O}$ (100 mL). Solvent was removed in vacuo to afford the corresponding aryl neopentyl boronate ester as a white solid for use in catalysis without further purification, unless stated otherwise. ${ }^{3}$

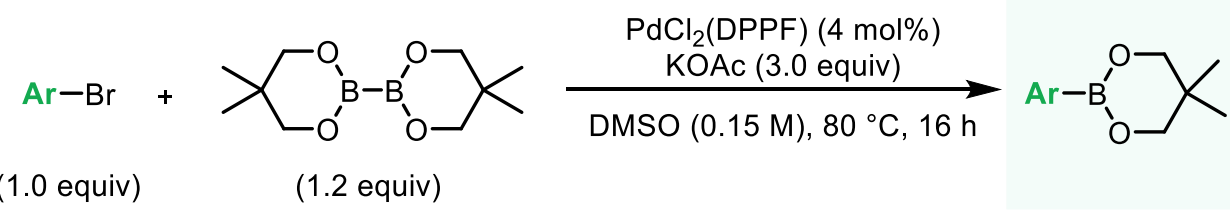

General procedure for synthesis of aryl neopentyl boronate esters from aryl bromides (Method B) ${ }^{4}:$ To a $20 \mathrm{~mL}$ vial equipped with a magnetic stirbar was added $\mathrm{PdCl}_{2}$ (DPPF) (58 mg, $0.08 \mathrm{mmol}, 0.04$ equiv), anhydrous potassium acetate (589 mg, $6.0 \mathrm{mmol}, 3.0$ equiv), bis(neopentyl glycolato)diboron (542 mg, $2.4 \mathrm{mmol}, 1.2$ equiv), and aryl bromide ( $2.0 \mathrm{mmol}, 1.0$ equiv). To these solids was added anhydrous dimethyl sulfoxide (14 $\mathrm{mL})$, forming a red-orange 
suspension. The reaction was sealed with a Telfon-lined cap, removed from the glovebox, and heated at $80 \stackrel{\circ}{ } \mathrm{C}$ for 18 h. The reaction mixture was allowed to cool to room temperature, then poured into ice-cold deionized water (75 $\mathrm{mL}$ ). The mixture was extracted with ethyl acetate $(3 \times 40 \mathrm{~mL})$, and the combined organic extracts were washed with saturated solution of aqueous $\mathrm{NaCl}(50 \mathrm{~mL})$, dried over anhydrous sodium sulfate, and concenrated in vacuo. The crude residue was dissolved in minimal dichloromethane and purified via flash chromatography on silica gel using ethyl acetate/hexanes gradient elution (5-50\%). Removal of solvent afforded the aryl neopentyl boronate ester as a white solid to be used in catalysis without further purification, unless otherwise stated. ${ }^{4}$ The ${ }^{13} \mathrm{C}$ NMR signal corresponding to the carbon of the $\mathrm{C}-\mathrm{B}$ bond for all boronate esters below is not observed due to broadening. ${ }^{5}$<smiles>CC1(C)COB(c2ccc(C#N)cc2)OC1</smiles>

4-(5,5-dimethyl-1,3,2-dioxaborinan-2-yl)benzonitrile (1b). Method A was followed and yielded a white solid (427 mg, 99\% yield). ${ }^{1} \mathrm{H}$ NMR (700 MHz, $\left.\mathrm{CDCl}_{3}\right) \delta 7.87$ (d, J = 7.7 Hz, 2H), 7.62 (d, J = $\left.7.7 \mathrm{~Hz}, 2 \mathrm{H}\right), 3.78$ (s, $\left.4 \mathrm{H}\right), 1.03$ (s, $6 \mathrm{H}) .{ }^{13} \mathrm{C}$ NMR $\left(176 \mathrm{MHz}, \mathrm{CDCl}_{3}\right) \delta 134.36,131.16,119.26,114.07,72.57,32.05,21.98$. HRMS (positive ion GC-APCI) calcd. for $\mathrm{C}_{12} \mathrm{H}_{14} \mathrm{BNO}_{2}[\mathrm{M}+\mathrm{H}] \mathrm{m} / \mathrm{z} 216.1190$. Found 216.1194 .<smiles>CC1(C)OB(c2ccc(C#N)cc2)OC1(C)C</smiles>

4-(4,4,5,5-tetramethyl-1,3,2-dioxaborolan-2-yl)benzonitrile (1c). Method A was followed, except 2,3dimethylbutane-2,3-diol (1.0 equiv) was used instead of 2,2-dimethyl-1,3-propanediol. The aryl pinacol boronate ester was obtained as white solid (455 mg, 99\% yield). ${ }^{1} \mathrm{H}$ NMR $\left(700 \mathrm{MHz}, \mathrm{CDCl}_{3}\right) \delta 7.88$ (d, J=7.9 Hz, $\left.2 \mathrm{H}\right), 7.63(\mathrm{~d}, J=7.9$ $\mathrm{Hz}, 2 \mathrm{H}$ ), 1.35 (s, 12H). ${ }^{13} \mathrm{C}$ NMR (176 MHz, $\mathrm{CDCl}_{3}$ ) $\delta 135.22,131.25,118.99,114.67,84.62,25.00$. HRMS (positive ion GC-APCI) calcd. for $\mathrm{C}_{13} \mathrm{H}_{16} \mathrm{BNO}_{2}[\mathrm{M}+\mathrm{H}] \mathrm{m} / \mathrm{z} 230.1347$. Found 230.1354.<smiles>Cc1cc(B2OCC(C)(C)CO2)ccc1C#N</smiles>

4-(5,5-dimethyl-1,3,2-dioxaborinan-2-yl)-2-methylbenzonitrile (2b). Method B was followed and yielded a white solid (302 mg, 66\% yield). ${ }^{1} \mathrm{H}$ NMR (401 MHz, $\left.\mathrm{CDCl}_{3}\right) \delta 7.73(\mathrm{~s}, 1 \mathrm{H}), 7.66(\mathrm{~d}, J=7.7 \mathrm{~Hz}, 1 \mathrm{H}), 7.56(\mathrm{~d}, J=7.7 \mathrm{~Hz}, 1 \mathrm{H})$, $3.78(\mathrm{~s}, 4 \mathrm{H}), 2.54(\mathrm{~s}, 3 \mathrm{H}), 1.02(\mathrm{~s}, 6 \mathrm{H}) .{ }^{13} \mathrm{C}$ NMR $\left(176 \mathrm{MHz}, \mathrm{CDCl}_{3}\right) \delta$ 140.73, 135.52, 131.60, 131.44, 118.55, 114.49, 72.57, 32.05, 21.99, 20.49. HRMS (positive ion GC-APCl) calcd. for $\mathrm{C}_{13} \mathrm{H}_{16} \mathrm{BNO}_{2}[\mathrm{M}+\mathrm{H}] \mathrm{m} / \mathrm{z} 230.1374$. Found 230.1352 .<smiles>CC1(C)COB(c2ccc(C(=O)c3ccccc3)cc2)OC1</smiles> 
(4-(5,5-dimethyl-1,3,2-dioxaborinan-2-yl)phenyl)(phenyl)methanone (3b). Method A was followed and yielded a white solid (560 mg, 95\% yield). ${ }^{1} \mathrm{H}$ NMR $\left(401 \mathrm{MHz}, \mathrm{CDCl}_{3}\right) \delta 7.91$ (d, $J=8.2 \mathrm{~Hz}, 2 \mathrm{H}$ ), 7.85-7.72 (multiple peaks, $4 \mathrm{H}$ ), 7.62-7.55 (m, 1H), 7.48 (t, $J=7.6 \mathrm{~Hz}, 2 \mathrm{H}), 3.80(\mathrm{~s}, 4 \mathrm{H}), 1.05$ (s, 6H). ${ }^{13} \mathrm{C} \mathrm{NMR}\left(176 \mathrm{MHz}, \mathrm{CDCl}_{3}\right) \delta$ 197.22, 139.42, $137.83,133.80,132.54,130.25,129.12,128.39,72.56,32.07,22.05$. HRMS (ESI+) calcd. for $\mathrm{C}_{18} \mathrm{H}_{19} \mathrm{BO}_{3}[\mathrm{M}+\mathrm{H}] \mathrm{m} / \mathrm{z}$ 295.1500. Found 295.1503.<smiles>CCCC(=O)c1ccc(B2OCC(C)(C)CO2)cc1</smiles>

1-(4-(5,5-dimethyl-1,3,2-dioxaborinan-2-yl)phenyl)butan-1-one (4b). Method B was followed and yielded a white solid (422.6 mg, 81\% yield). ${ }^{1} \mathrm{H} \mathrm{NMR}\left(500 \mathrm{MHz}, \mathrm{CDCl}_{3}\right.$ ) $\delta$ 8.13-7.76 (multiple peaks, 4H), 3.78 (s, 4H), 2.95 (t, $J=7.3$ $\mathrm{Hz}, 2 \mathrm{H}), 1.81-1.72(\mathrm{~m}, 2 \mathrm{H}), 1.08-0.98$ (multiple peaks, 9H). ${ }^{13} \mathrm{C}$ NMR $\left(126 \mathrm{MHz}, \mathrm{CDCl}_{3}\right) \delta 201.00,138.77,134.13$, $127.09,72.53,40.84,32.05,22.03,17.93,14.04$. HRMS (positive ion GC-APCl) calcd. for $\mathrm{C}_{15} \mathrm{H}_{21} \mathrm{BO}_{3}[\mathrm{M}+\mathrm{H}] \mathrm{m} / \mathrm{z}$ 261.1657. Found 261.1661.<smiles>CC1(C)COB(c2ccc3c(c2)C(=O)c2ccccc2C3=O)OC1</smiles>

2-(5,5-dimethyl-1,3,2-dioxaborinan-2-yl)anthracene-9,10-dione (5b). Method B was followed and yielded a yellow solid (419 mg, 65\% yield). ${ }^{1} \mathrm{H}$ NMR $\left(500 \mathrm{MHz}, \mathrm{CDCl}_{3}\right) \delta 8.77-8.71(\mathrm{~m}, 1 \mathrm{H}), 8.37-8.28$ (multiple peaks, $2 \mathrm{H}$ ), 8.27 (d, $\mathrm{J}=$ $7.6 \mathrm{~Hz}, 1 \mathrm{H}$ ), 8.20 (dd, $J=7.7,1.3 \mathrm{~Hz}, 1 \mathrm{H}$ ), 7.83-7.75 (multiple peaks, $2 \mathrm{H}$ ), $3.83(\mathrm{~s}, 4 \mathrm{H}), 1.05(\mathrm{~s}, 6 \mathrm{H}) .{ }^{13} \mathrm{C}$ NMR $(176$ $\left.\mathrm{MHz}, \mathrm{CDCl}_{3}\right) \delta 183.71,183.51,139.44,134.91,134.20,134.07,133.82,133.78,133.06,132.54,127.38,127.29$, 126.20, 72.62, 32.10, 22.04. HRMS (ESI+) calcd. for $\mathrm{C}_{19} \mathrm{H}_{17} \mathrm{BO}_{4}[\mathrm{M}+\mathrm{H}] \mathrm{m} / \mathrm{z} 321.1293$. Found 321.1306.<smiles>CCOC(=O)c1ccc(B2OCC(C)(C)CO2)cc1</smiles>

ethyl 4-(5,5-dimethyl-1,3,2-dioxaborinan-2-yl)benzoate (6b). Method A was followed and yielded a white solid (471 $\mathrm{mg}, 90 \%$ yield). ${ }^{1} \mathrm{H} \mathrm{NMR}\left(401 \mathrm{MHz}, \mathrm{CDCl}_{3}\right) \delta 8.01$ (d, $\left.J=8.2 \mathrm{~Hz}, 2 \mathrm{H}\right), 7.86(\mathrm{~d}, J=8.2 \mathrm{~Hz}, 2 \mathrm{H}), 4.38$ (q, $J=7.1 \mathrm{~Hz}, 2 \mathrm{H}$ ), $3.78(\mathrm{~s}, 4 \mathrm{H}), 1.40(\mathrm{t}, J=7.1 \mathrm{~Hz}, 3 \mathrm{H}), 1.03(\mathrm{~s}, 6 \mathrm{H}) .{ }^{13} \mathrm{C} \mathrm{NMR}\left(176 \mathrm{MHz}, \mathrm{CDCl}_{3}\right) \delta 166.99,133.86,132.32,128.60,72.53$, 61.08, 32.05, 22.05, 14.49. HRMS (positive ion GC-APCl) calcd. for $\mathrm{C}_{14} \mathrm{H}_{19} \mathrm{BO}_{4}[\mathrm{M}+] \mathrm{m} / \mathrm{z} 263.1449$. Found 263.1454.<smiles>COC(=O)c1ccc(B2OCC(C)(C)CO2)cc1</smiles> 
methyl 4-(5,5-dimethyl-1,3,2-dioxaborinan-2-yl)benzoate (7b). Method A was followed and yielded a white solid (468 mg, 94\% yield). ${ }^{1} \mathrm{H}$ NMR (401 MHz, $\left.\mathrm{CDCl}_{3}\right) \delta 8.01$ (d, $J=8.2 \mathrm{~Hz}, 2 \mathrm{H}$ ), 7.86 (d, $J=8.2 \mathrm{~Hz}, 2 \mathrm{H}$ ), 3.91 (s, 3H), 3.78 (s, 4H), 1.03 (s, 6H). $\left.{ }^{13} \mathrm{C} \mathrm{NMR} \mathrm{(126} \mathrm{MHz,} \mathrm{CDCl}_{3}\right) \delta 167.46,133.90,131.95,128.64,72.53,52.22,32.04,22.04$. HRMS (positive ion GC-APCl) calcd. for $\mathrm{C}_{13} \mathrm{H}_{17} \mathrm{BO}_{4}[\mathrm{M}+\mathrm{H}] \mathrm{m} / \mathrm{z} 249.1293$. Found 249.1298.<smiles>CCOC(=O)c1cc(B2OCC(C)(C)CO2)cc(C(=O)OCC)c1</smiles>

diethyl 5-(5,5-dimethyl-1,3,2-dioxaborinan-2-yl)isophthalate (8b). Method A was followed and yielded a white solid (662 mg, 99\% yield). ${ }^{1} \mathrm{H} \mathrm{NMR}\left(500 \mathrm{MHz}, \mathrm{CDCl}_{3}\right) \delta 8.73(\mathrm{~s}, 1 \mathrm{H}), 8.62$ (s, 2H), 4.41 (q, J = 7.4 Hz, 4H), $3.80(\mathrm{~s}, 4 \mathrm{H}), 1.41$ (t, $J=7.5 \mathrm{~Hz}, 6 \mathrm{H}), 1.03$ (s, 6H). ${ }^{13} \mathrm{C}$ NMR $\left(176 \mathrm{MHz}, \mathrm{CDCl}_{3}\right) \delta 166.27,139.11,132.89,130.33,72.54,61.31,32.08$, 22.01, 14.52. HRMS (positive ion GC-APCl) calcd. for $\mathrm{C}_{17} \mathrm{H}_{23} \mathrm{BO}_{6}[\mathrm{M}+\mathrm{H}] \mathrm{m} / z$ 335.166. Found 335.1164.<smiles>CC1(C)COB(c2ccc(-c3nc4ccccc4s3)cc2)OC1</smiles>

2-(4-(5,5-dimethyl-1,3,2-dioxaborinan-2-yl)phenyl)benzo[d]thiazole (9b). Method B was followed and yielded a white solid (595 mg, 91\% yield). ${ }^{1} \mathrm{H}$ NMR ( $500 \mathrm{MHz}, \mathrm{CDCl}_{3}$ ) $\delta$ 8.08-7.90 (multiple peaks, 3H), 7.95-7.87 (multiple peaks, $3 \mathrm{H}), 7.49(\mathrm{~m}, J=7.7 \mathrm{~Hz}, 1 \mathrm{H}), 7.39(\mathrm{t}, J=8.1 \mathrm{~Hz}, 1 \mathrm{H}), 3.80(\mathrm{~s}, 4 \mathrm{H}), 1.05(\mathrm{~s}, 6 \mathrm{H}) .{ }^{13} \mathrm{C} \mathrm{NMR}\left(126 \mathrm{MHz}, \mathrm{CDCl}_{3}\right) \delta 168.42$, 154.33, 135.48, 135.27, 134.62, 126.75, 126.45, 125.36, 123.43, 121.77, 72.55, 32.08, 22.08. HRMS (positive ion GCAPCl) calcd. for $\mathrm{C}_{18} \mathrm{H}_{18} \mathrm{BNO}_{2} \mathrm{~S}[\mathrm{M}+\mathrm{H}] \mathrm{m} / \mathrm{z}$ 324.1224. Found 324.1234.<smiles>Cc1nc(-c2ccc(B3OCC(C)(C)CO3)cc2)no1</smiles>

3-(4-(5,5-dimethyl-1,3,2-dioxaborinan-2-yl)phenyl)-5-methyl-1,2,4-oxadiazole (10b). Method B was followed and yielded a white solid (418 mg, 77\% yield). ${ }^{1} \mathrm{H}$ NMR $\left(401 \mathrm{MHz}, \mathrm{CDCl}_{3}\right) \delta 8.04(\mathrm{~d}, \mathrm{~J}=8.1 \mathrm{~Hz}, 2 \mathrm{H}), 7.90(\mathrm{~d}, \mathrm{~J}=8.1 \mathrm{~Hz}$, $2 \mathrm{H}), 3.79(\mathrm{~s}, 4 \mathrm{H}), 2.65(\mathrm{~s}, 3 \mathrm{H}), 1.04(\mathrm{~s}, 6 \mathrm{H}) .{ }^{13} \mathrm{C} \mathrm{NMR}\left(176 \mathrm{MHz}, \mathrm{CDCl}_{3}\right) \delta 176.63,168.68,134.42,128.71,126.51$, 72.52, 32.06, 22.06, 12.56. HRMS (positive ion GC-APCl) calcd. for $\mathrm{C}_{14} \mathrm{H}_{17} \mathrm{BN}_{2} \mathrm{O}_{3}[\mathrm{M}+\mathrm{H}] \mathrm{m} / \mathrm{z} 273.1405$. Found 273.1408 . 
<smiles>CC(C)S(=O)(=O)c1ccc(B2OCC(C)(C)CO2)cc1</smiles>

2-(4-(isopropylsulfonyl)phenyl)-5,5-dimethyl-1,3,2-dioxaborinane (11b). Method A was followed and yielded a white solid (569 mg, 96\% yield). ${ }^{1} \mathrm{H}$ NMR $\left(401 \mathrm{MHz}, \mathrm{CDCl}_{3}\right) \delta 7.96(\mathrm{~d}, J=8.3 \mathrm{~Hz}, 2 \mathrm{H}), 7.82(\mathrm{~d}, J=8.3 \mathrm{~Hz}, 2 \mathrm{H}), 3.78$ (s, 4H), 3.17 (hept, $J=6.9 \mathrm{~Hz}, 1 \mathrm{H}), 1.26(\mathrm{~d}, J=6.9 \mathrm{~Hz}, 6 \mathrm{H}), 1.02(\mathrm{~s}, 6 \mathrm{H}) .{ }^{13} \mathrm{C} \mathrm{NMR}\left(176 \mathrm{MHz}, \mathrm{CDCl}_{3}\right) \delta$ 138.59, 134.42 , 127.97, 72.54, 55.61, 32.01, 21.95, 15.78. HRMS (positive ion GC-APCl) calcd. for $\mathrm{C}_{14} \mathrm{H}_{21} \mathrm{BO}_{4} \mathrm{~S}\left[\mathrm{M}+\mathrm{NH}_{4}\right] \mathrm{m} / z 342.1592$. Found 342.1909.<smiles>CN(C)S(=O)(=O)c1ccc(B2OCC(C)(C)CO2)cc1</smiles>

4-(5,5-dimethyl-1,3,2-dioxaborinan-2-yl)-N,N-dimethylbenzenesulfonamide (12b). Method A was followed and yielded a white solid (517 mg, 87\% yield). ${ }^{1} \mathrm{H}$ NMR $\left(500 \mathrm{MHz}, \mathrm{CDCl}_{3}\right) \delta 7.95(\mathrm{~d}, \mathrm{~J}=8.1 \mathrm{~Hz}, 2 \mathrm{H}), 7.81-7.69(\mathrm{~m}, 2 \mathrm{H})$, $3.79(\mathrm{~s}, 4 \mathrm{H}), 2.68(\mathrm{~s}, 6 \mathrm{H}), 1.03(\mathrm{~s}, 6 \mathrm{H}) .{ }^{13} \mathrm{C} \mathrm{NMR}\left(176 \mathrm{MHz}, \mathrm{CDCl}_{3}\right) \delta$ 137.09, 134.46, 126.75, 72.57, 38.08, 32.05, 21.99. HRMS (positive ion GC-APCl) calcd. for $\mathrm{C}_{13} \mathrm{H}_{20} \mathrm{BNO}{ }_{4} \mathrm{~S}[\mathrm{M}+\mathrm{H}] \mathrm{m} / \mathrm{z}$ 298.1279. Found 298.1292.<smiles>CCCN(CCC)S(=O)(=O)c1ccc(B2OCC(C)(C)CO2)cc1</smiles>

4-(5,5-dimethyl-1,3,2-dioxaborinan-2-yl)-N,N-dipropylbenzenesulfonamide (13b). Substrate was synthesized and isolated according to a previously reported procedure ${ }^{6}$ and yielded a white solid $\left(80.5 \mathrm{mg}, 76 \%\right.$ yield). ${ }^{1} \mathrm{H}$ NMR (401 $\left.\mathrm{MHz}, \mathrm{CDCl}_{3}\right) \delta 7.90(\mathrm{~d}, J=8.3 \mathrm{~Hz}, 2 \mathrm{H}), 7.76(\mathrm{~d}, J=8.3 \mathrm{~Hz}, 2 \mathrm{H}), 3.78(\mathrm{~s}, 4 \mathrm{H}), 3.10-3.03(\mathrm{~m}, 4 \mathrm{H}), 1.58-1.48(\mathrm{~m}, 4 \mathrm{H})$, 1.03 (s, 6H), 0.86 (t, $J=7.4 \mathrm{~Hz}, 6 \mathrm{H}) .{ }^{13} \mathrm{C}$ NMR $\left(176 \mathrm{MHz}, \mathrm{CDCl}_{3}\right) \delta 141.92,134.46,126.08,72.57,50.12,32.06,22.11$, 22.03, 11.34. HRMS (positive ion GC-APCl) calcd. for $\mathrm{C}_{17} \mathrm{H}_{28} \mathrm{BNO}_{4} \mathrm{~S}[\mathrm{M}+\mathrm{H}] \mathrm{m} / z$ 354.1905. Found 354.1905.<smiles>CC1(C)COB(c2cc(C(F)(F)F)cc(S(C)(=O)=O)c2)OC1</smiles>

5,5-dimethyl-2-(3-(methylsulfonyl)-5-(trifluoromethyl)phenyl)-1,3,2-dioxaborinane (14b). Method B was followed and yielded a white solid (544 mg, 81\% yield). $\left.{ }^{1} \mathrm{H} \mathrm{NMR} \mathrm{(500} \mathrm{MHz,} \mathrm{CDCl}_{3}\right) \delta 8.54(\mathrm{~s}, 1 \mathrm{H}), 8.31(\mathrm{~s}, 1 \mathrm{H}), 8.25(\mathrm{~s}, 1 \mathrm{H})$, $3.81(\mathrm{~s}, 4 \mathrm{H}), 3.09$ (s, 3H), $1.04(\mathrm{~s}, 6 \mathrm{H}) .{ }^{19} \mathrm{~F}$ NMR $\left(377 \mathrm{MHz}, \mathrm{CDCl}_{3}\right) \delta-62.90 .{ }^{13} \mathrm{C}$ NMR $\left(176 \mathrm{MHz}, \mathrm{CDCl}_{3}\right) \delta 140.98$, 135.97, 135.69 (q, $J=3.3 \mathrm{~Hz}$ ), 131.40 (q, $J=33.3 \mathrm{~Hz}$ ), 126.35 (q, $J=3.7 \mathrm{~Hz}$ ), 123.50 (q, $J=273.0 \mathrm{~Hz}$ ), 72.66, 44.55, 32.14, 21.95. HRMS (positive ion GC-APCl) calcd. for $\mathrm{C}_{13} \mathrm{H}_{16} \mathrm{BF}_{3} \mathrm{O}_{4} \mathrm{~S}[\mathrm{M}+\mathrm{H}] \mathrm{m} / z$ 337.0887. Found 337.0898. 
<smiles>CC1(C)COB(c2cc(C(F)(F)F)cc(C(F)(F)F)c2)OC1</smiles>

2-(3,5-bis(trifluoromethyl)phenyl)-5,5-dimethyl-1,3,2-dioxaborinane (15b). Method A was followed and yielded a white solid (639 mg, 98\% yield). ${ }^{1} \mathrm{H}$ NMR $\left(500 \mathrm{MHz}, \mathrm{CDCl}_{3}\right) \delta 8.24$ (s, 2H), 7.91 (s, 1H), $3.81(\mathrm{~s}, 4 \mathrm{H}), 1.04$ (s, 6H). ${ }^{19} \mathrm{~F}$ NMR $\left(377 \mathrm{MHz}, \mathrm{CDCl}_{3}\right) \delta-62.87 .{ }^{13} \mathrm{C}$ NMR $\left(176 \mathrm{MHz}, \mathrm{CDCl}_{3}\right) \delta 133.99,130.79$ (q, $J=32.9 \mathrm{~Hz}$ ), 124.30, 123.82 (q, $J$ $=272.5 \mathrm{~Hz}$ ), 72.64, 32.13, 21.96. HRMS (positive ion GC-APCl) calcd. for $\mathrm{C}_{13} \mathrm{H}_{13} \mathrm{BF}_{6} \mathrm{O}_{2}[\mathrm{M}+\mathrm{H}] \mathrm{m} / z$ 327.0986. Found 327.0985 .<smiles>CC1(C)COB(c2ccc(C(F)(F)F)cc2)OC1</smiles>

5,5-dimethyl-2-(4-(trifluoromethyl)phenyl)-1,3,2-dioxaborinane (16b). Method A was followed and yielded a white solid (485 mg, 94\% yield). ${ }^{1} \mathrm{H}$ NMR (500 MHz, $\left.\mathrm{CDCl}_{3}\right) \delta 7.90$ (d, $\left.J=7.7 \mathrm{~Hz}, 2 \mathrm{H}\right), 7.60$ (d, $\left.J=7.6 \mathrm{~Hz}, 2 \mathrm{H}\right), 3.79$ (s, 4H), $1.03(\mathrm{~s}, 6 \mathrm{H}) .{ }^{19} \mathrm{~F}$ NMR $\left(377 \mathrm{MHz}, \mathrm{CDCl}_{3}\right) \delta-62.93 .{ }^{13} \mathrm{C} \mathrm{NMR}\left(176 \mathrm{MHz}, \mathrm{CDCl}_{3}\right) \delta 134.24,132.41$ (q, $\mathrm{J}=31.9 \mathrm{~Hz}$ ), 124.44 (q, $J=272.2 \mathrm{~Hz}$ ), 124.31 (q, $J=3.7 \mathrm{~Hz}$ ), 72.54, 32.05, 22.00. HRMS (positive ion GC-APCl) calcd. for $\mathrm{C}_{12} \mathrm{H}_{14} \mathrm{BF}_{3} \mathrm{O}_{2}[\mathrm{M}+\mathrm{H}] \mathrm{m} / \mathrm{z}$ 259.1112. Found 259.1120 .<smiles>CC1(C)COB(c2ccc(F)c(F)c2)OC1</smiles>

2-(3,4-difluorophenyl)-5,5-dimethyl-1,3,2-dioxaborinane (17b). Method A was followed and yielded a yellow solid (408 mg, 90\% yield). ${ }^{1} \mathrm{H}$ NMR (500 MHz, $\mathrm{CDCl}_{3}$ ) $\delta 7.62-7.49$ (multiple peaks, $2 \mathrm{H}$ ), 7.12 (dt, $J=10.5,7.9 \mathrm{~Hz}, 1 \mathrm{H}$ ), 3.76 (s, 4H), $1.02(\mathrm{~s}, 6 \mathrm{H}) .{ }^{19} \mathrm{~F} \mathrm{NMR}\left(471 \mathrm{MHz}, \mathrm{CDCl}_{3}\right) \delta-135.53$ (dtd, $\left.J=20.0,9.5,4.8 \mathrm{~Hz}\right),-140.35$ (ddd, $J=19.8,11.1$, $7.7 \mathrm{~Hz}$ ). ${ }^{13} \mathrm{C}$ NMR $\left(176 \mathrm{MHz}, \mathrm{CDCl}_{3}\right) \delta 152.43$ (dd, $J=251.1,12.7 \mathrm{~Hz}$ ), 150.31 (dd, $J=248.0,11.9 \mathrm{~Hz}$ ), 130.45 (dd, $J$ = 6.6, $3.7 \mathrm{~Hz}), 122.54(\mathrm{~d}, J=15.2 \mathrm{~Hz}), 116.76(\mathrm{~d}, J=16.2 \mathrm{~Hz}$ ), 72.50, 32.04, 22.00. HRMS (positive ion GC-APCl) calcd. for $\mathrm{C}_{11} \mathrm{H}_{13} \mathrm{BF}_{2} \mathrm{O}_{2}[\mathrm{M}+\mathrm{H}] \mathrm{m} / \mathrm{z} 227.1049$. Found 227.1043.<smiles>CC1(C)COB(c2ccc(OC(F)(F)F)cc2)OC1</smiles>

5,5-dimethyl-2-(4-(trifluoromethoxy)phenyl)-1,3,2-dioxaborinane (18b). Method A was followed and yielded a white solid (521 mg, 95\% yield). ${ }^{1} \mathrm{H}$ NMR $\left(500 \mathrm{MHz}, \mathrm{CDCl}_{3}\right) \delta 7.83(\mathrm{~d}, J=8.5 \mathrm{~Hz}, 2 \mathrm{H}), 7.18$ (d, J=7.9 Hz, 2H), 3.77 $(\mathrm{s}, 4 \mathrm{H}), 1.02(\mathrm{~s}, 6 \mathrm{H}) .{ }^{19} \mathrm{~F} \mathrm{NMR}\left(471 \mathrm{MHz}, \mathrm{CDCl}_{3}\right) \delta-57.84 .{ }^{13} \mathrm{C} \mathrm{NMR}\left(176 \mathrm{MHz}, \mathrm{CDCl}_{3}\right) \delta 151.46,135.71,120.62$ (q, $J$ $=257.1 \mathrm{~Hz}$ ), 119.86, 72.49, 32.03, 21.99. HRMS (positive ion GC-APCl) calcd. for $\mathrm{C}_{12} \mathrm{H}_{14} \mathrm{BF}_{3} \mathrm{O}_{3}[\mathrm{M}+\mathrm{H}] \mathrm{m} / \mathrm{z} 275.1061$. Found 275.1066. 
<smiles>COc1ccc(B2OCC(C)(C)CO2)cc1</smiles>

2-(4-methoxyphenyl)-5,5-dimethyl-1,3,2-dioxaborinane (19b). Method A was followed and yielded a white solid (406 mg, 93\%). ${ }^{1} \mathrm{H}$ NMR (500 MHz, $\left.\mathrm{CDCl}_{3}\right) \delta 7.74$ (d, $\left.J=8.5 \mathrm{~Hz}, 2 \mathrm{H}\right), 6.89$ (d, J = 8.6 Hz, 2H), $3.82(\mathrm{~s}, 3 \mathrm{H}), 3.75$ (s, 4H), 1.02 (s, 6H). ${ }^{13} \mathrm{C}$ NMR (126 MHz, $\left.\mathrm{CDCl}_{3}\right) \delta 161.89,135.65,113.29,72.41,55.20,32.05,22.08$. HRMS (positive ion GC-APCl) calcd. for $\mathrm{C}_{12} \mathrm{H}_{17} \mathrm{BO}_{3}[\mathrm{M}+] \mathrm{m} / z$ 220.1271. Found 220.1277 .

VIII. Procedure for catalytic reactions with fluoroalkyl anhydrides and fluoride salts (Figure 8 in manuscript)

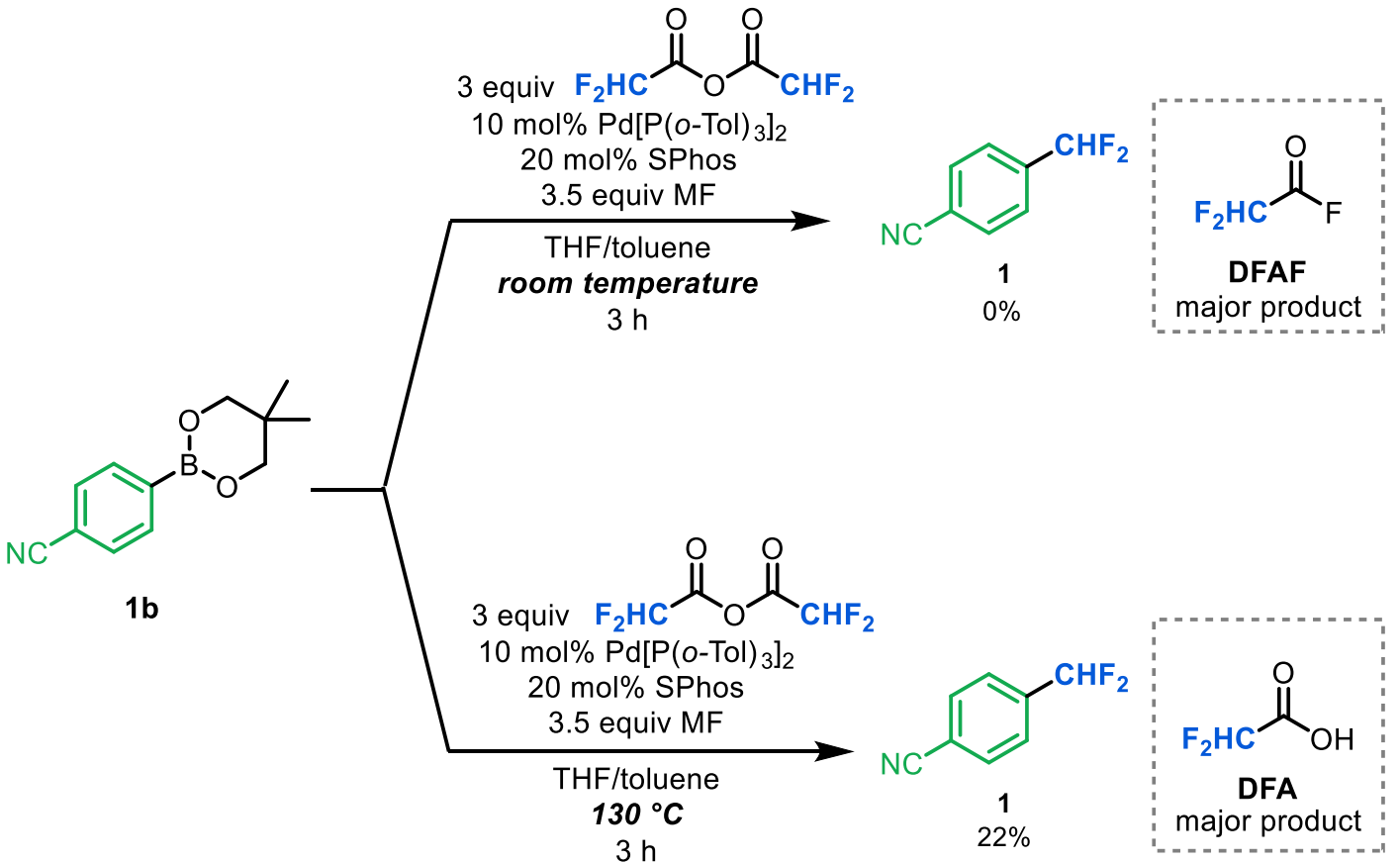

General procedure for the catalytic reaction with DFAAn and fluoride salts: $\mathrm{Pd}\left[\mathrm{P}(0-\mathrm{Tol})_{3}\right]_{2}(4.1 \mathrm{mg}, 0.005 \mathrm{mmol}$, 0.1 equiv, $3.6 \mathrm{mg}$ ) and SPhos ( $4.1 \mathrm{mg}, 0.01 \mathrm{mmol}, 0.2$ equiv) were combined in THF ( $0.15 \mathrm{~mL})$. The yellow suspension was stirred vigorously in a tall $10 \mathrm{~mL}$ vial for $15 \mathrm{~min}$. To this solution was added a toluene-solution of DFAAn $(0.2 \mathrm{~mL}$, $0.75 \mathrm{M}, 0.15 \mathrm{mmol}, 3$ equiv), then $\mathbf{1 b}$ (10.8 $\mathrm{mg}, 0.05 \mathrm{mmol}, 1$ equiv), and finally CsF, NMe4F, or NBu4F (0.175 mmol, 3.5 equiv). The vial was sealed with a Teflon-lined screw cap with a septum, removed from the glovebox, and heated to the appropriate temperature for $3 \mathrm{~h}$. After $3 \mathrm{~h}$, the reaction mixture was allowed to cool to room temperature, and then 4-fluorotoluene (25 $\mathrm{LL}, 2.0 \mathrm{M}$ in DCM, 1.0 equiv) was added as an internal standard, followed by dichloromethane $(1.0 \mathrm{~mL})$. The mixture was filtered through a plug of celite, and an aliquot of the solution was transferred to an NMR tube and analyzed by ${ }^{19} \mathrm{~F}$ NMR spectroscopy to determine the yield of $\mathbf{1}$ as well as the identity of major by-products.

Conducting the reaction at room temperature with 3 equiv of DFAAn and 3.6 equiv of CsF produced no observable quantity of 1. However, in the crude ${ }^{19} \mathrm{~F}$ NMR spectra of these reactions, DFAF was observed as a major side product. In the reactions with $\mathrm{NMe}_{4} \mathrm{~F}$ or $\mathrm{NBu}_{4} \mathrm{~F}$, DFAF was not observed, and DFA was a major side product. 
Reactions conducted at $130{ }^{\circ} \mathrm{C}$ using 3 equiv of DFAAn and 3.6 equiv CsF produced modest but variable yields of 1 (17-31\%). The range of $17-31 \%$ represents four reactions set up under identical conditions, with yields of $15 \%, 17 \%$, $24 \%$, and $31 \%$, respectively, emphasizing the poor reproducibility of this transformation. Using equimolar amounts of CsF to DFAAn under otherwise analogous conditions resulted in significantly lower yields of 1 (4-9\%). Reactions conducted using $\mathrm{NMe}_{4} \mathrm{~F}$ or $\mathrm{NBu}_{4} \mathrm{~F}$ produced no observable quantity of 1 or DFAF in these experiments, as determined by ${ }^{19} \mathrm{~F}$ NMR spectroscopy.

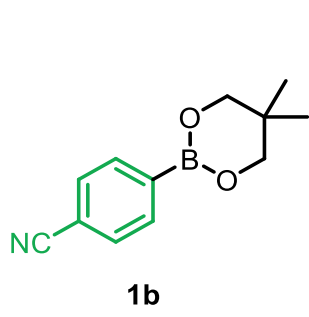

$1 \mathrm{~b}$

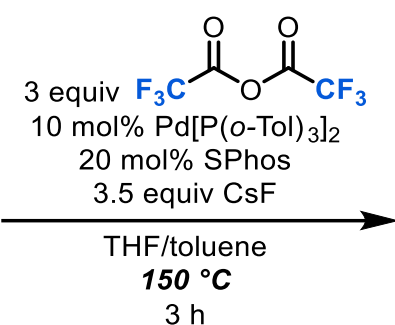

$3 \mathrm{~h}$
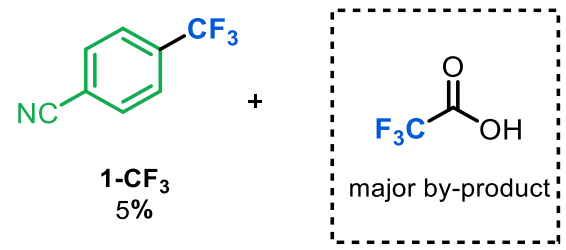

General procedure for the catalytic reaction with TFAAn and CsF: $\mathrm{Pd}\left[\mathrm{P}(0-\mathrm{Tol})_{3}\right]_{2}(4.1 \mathrm{mg}, 0.005 \mathrm{mmol}, 0.1$ equiv, $3.6 \mathrm{mg}$ ) and SPhos (4.1 mg, $0.01 \mathrm{mmol}, 0.2$ equiv) were combined in THF $(0.15 \mathrm{~mL})$. The yellow suspension was stirred vigorously in a tall $10 \mathrm{~mL}$ vial for $15 \mathrm{~min}$. To this solution was added a toluene-solution of TFAAn $(0.2 \mathrm{~mL}, 0.75$ M, $0.15 \mathrm{mmol}, 3$ equiv), then $\mathbf{1 b}$ (10.8 mg, $0.05 \mathrm{mmol}, 1$ equiv), and finally CsF, (26.6 mg, $0.175 \mathrm{mmol}, 3.5$ equiv). The vial was sealed with a Teflon-lined screw cap with a septum, removed from the glovebox, and heated to the appropriate temperature for $3 \mathrm{~h}$. After $3 \mathrm{~h}$, the reaction mixture was allowed to cool to room temperature, and then 4-fluorotoluene (25 $\mu \mathrm{L}, 2.0 \mathrm{M}$ in DCM, 1.0 equiv) was added as an internal standard, followed by dichloromethane $(1.0 \mathrm{~mL})$. The mixture was filtered through a plug of celite, and an aliquot of the solution was transferred to an NMR tube and analyzed by ${ }^{19} \mathrm{~F}$ NMR spectroscopy to determine the yield of 4-trifluoromethylbenzonitrile, 1-CF 3 . Spiking in an authentic sample of 1$\mathrm{CF}_{3}$ to the crude reaction mixture confirmed its presence in the crude reaction mixture. The associated ${ }^{19} \mathrm{~F}$ NMR spectra are shown below in Figure S15. 

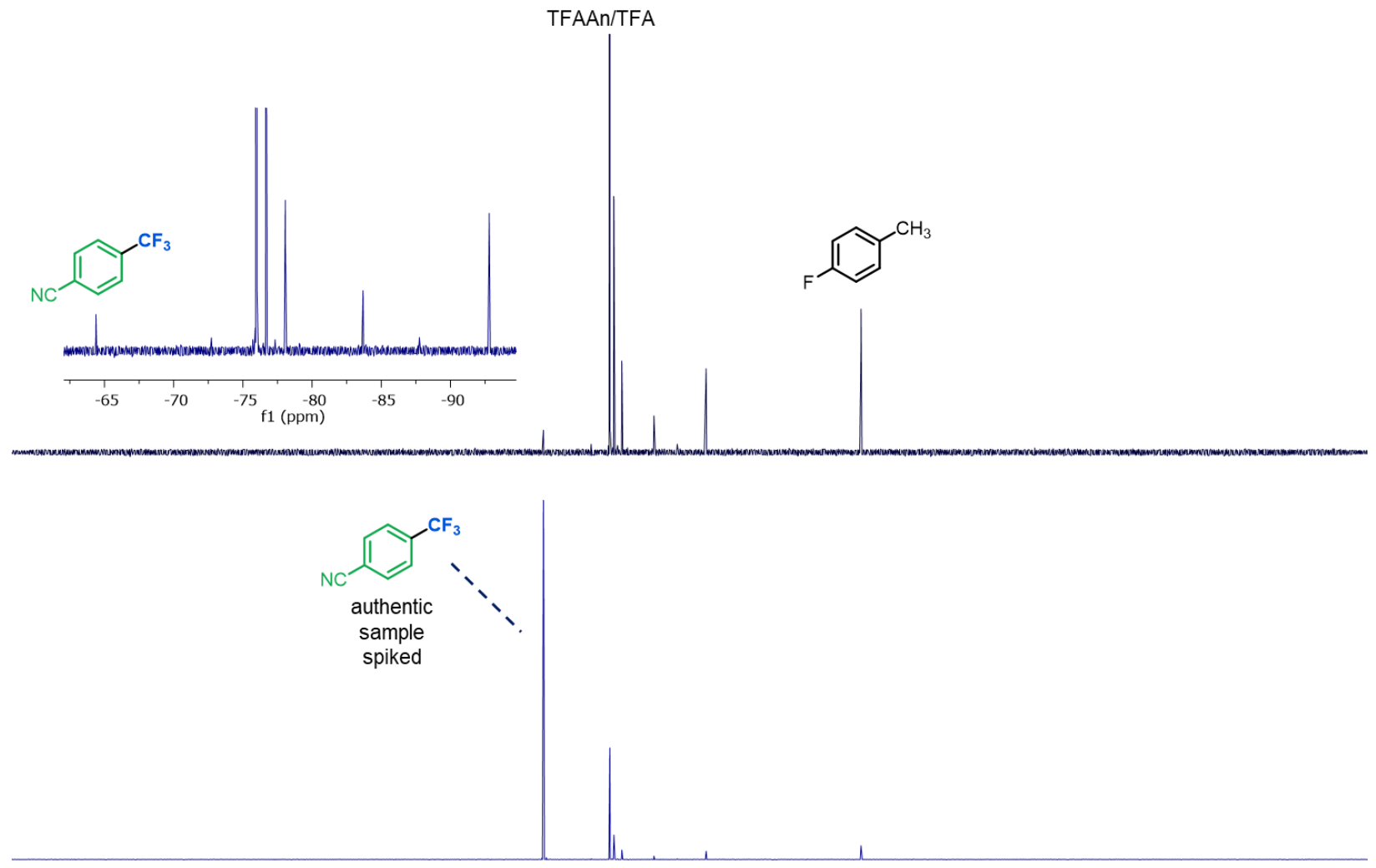

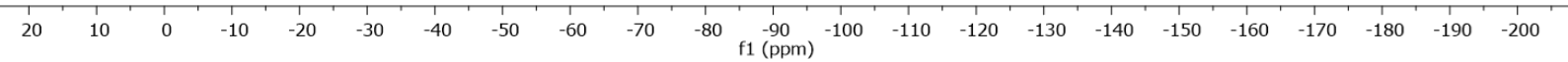

Figure S15. (Top) ${ }^{19} \mathrm{~F}$ NMR of crude reaction with 4-fluorotoluene internal standard showing 4trifluoromethylbenzonitrile, $\mathbf{1}-\mathbf{C F}_{\mathbf{3}}$ and (bottom) ${ }^{19} \mathrm{~F}$ NMR of crude reaction after spiking in an authentic sample of 1-CF 3.
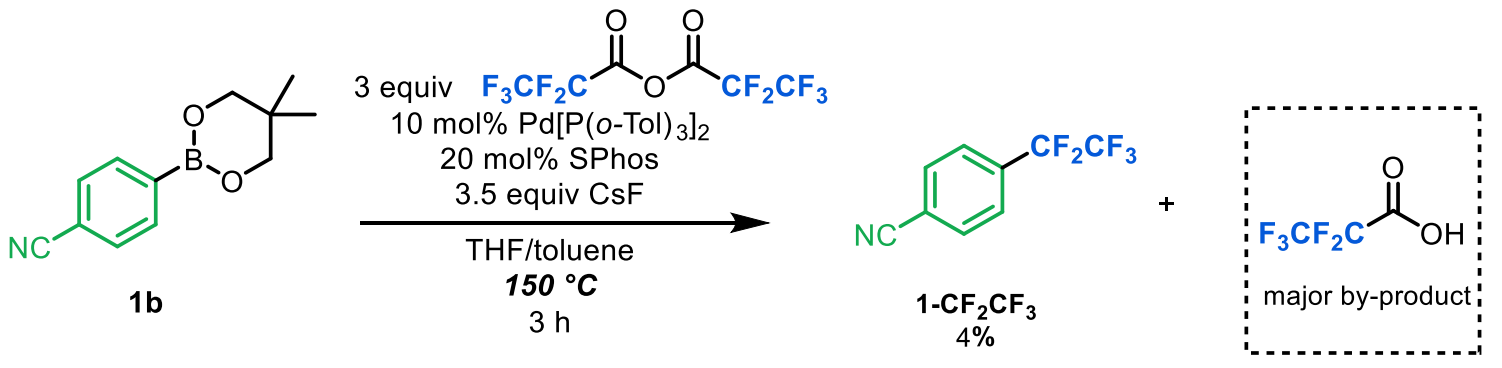

General procedure for the catalytic reaction with PFPAn and CsF: $\mathrm{Pd}\left[\mathrm{P}(\mathrm{O}-\mathrm{Tol})_{3}\right]_{2}(4.1 \mathrm{mg}, 0.005 \mathrm{mmol}, 0.1 \mathrm{equiv}$, $3.6 \mathrm{mg})$ and SPhos $(4.1 \mathrm{mg}, 0.01 \mathrm{mmol}, 0.2$ equiv) were combined in THF $(0.15 \mathrm{~mL})$ and toluene $(0.2 \mathrm{~mL})$. The yellow suspension was stirred vigorously in a tall $10 \mathrm{~mL}$ vial for $15 \mathrm{~min}$. To this solution was added a PFPAn (46.5 mg, 0.15 mmol, 3 equiv), then $\mathbf{1 b}$ (10.8 mg, $0.05 \mathrm{mmol}, 1$ equiv), and finally $\mathrm{CsF},(26.6 \mathrm{mg}, 0.175 \mathrm{mmol}, 3.5$ equiv). The vial was sealed with a Teflon-lined screw cap with a septum, removed from the glovebox, and heated to the appropriate temperature for $3 \mathrm{~h}$. After $3 \mathrm{~h}$, the reaction mixture was allowed to cool to room temperature, and then 4-fluorotoluene (25 $\mu \mathrm{L}, 2.0 \mathrm{M}$ in DCM, 1.0 equiv) was added as an internal standard, followed by dichloromethane (1.0 mL). The mixture was filtered through a plug of celite, and an aliquot of the solution was transferred to an NMR tube and analyzed by ${ }^{19} \mathrm{~F}$ NMR spectroscopy (Figure S16) to determine the yield of $\mathbf{1 - C F} \mathbf{C F}_{\mathbf{3}}$. Spectral data for this product in this reaction $\left({ }^{19} \mathrm{~F}\right.$ 
NMR: $-85.51 \mathrm{ppm}(\mathrm{s}, 3 \mathrm{~F}),-116.55 \mathrm{ppm}(\mathrm{s}, 2 \mathrm{~F}))$ are consistent with our previous report ${ }^{7}$ and other reports ${ }^{8}$ in the literature. Pentafluoropropionic acid (PFPA) was observed (55\%) in the crude reaction.

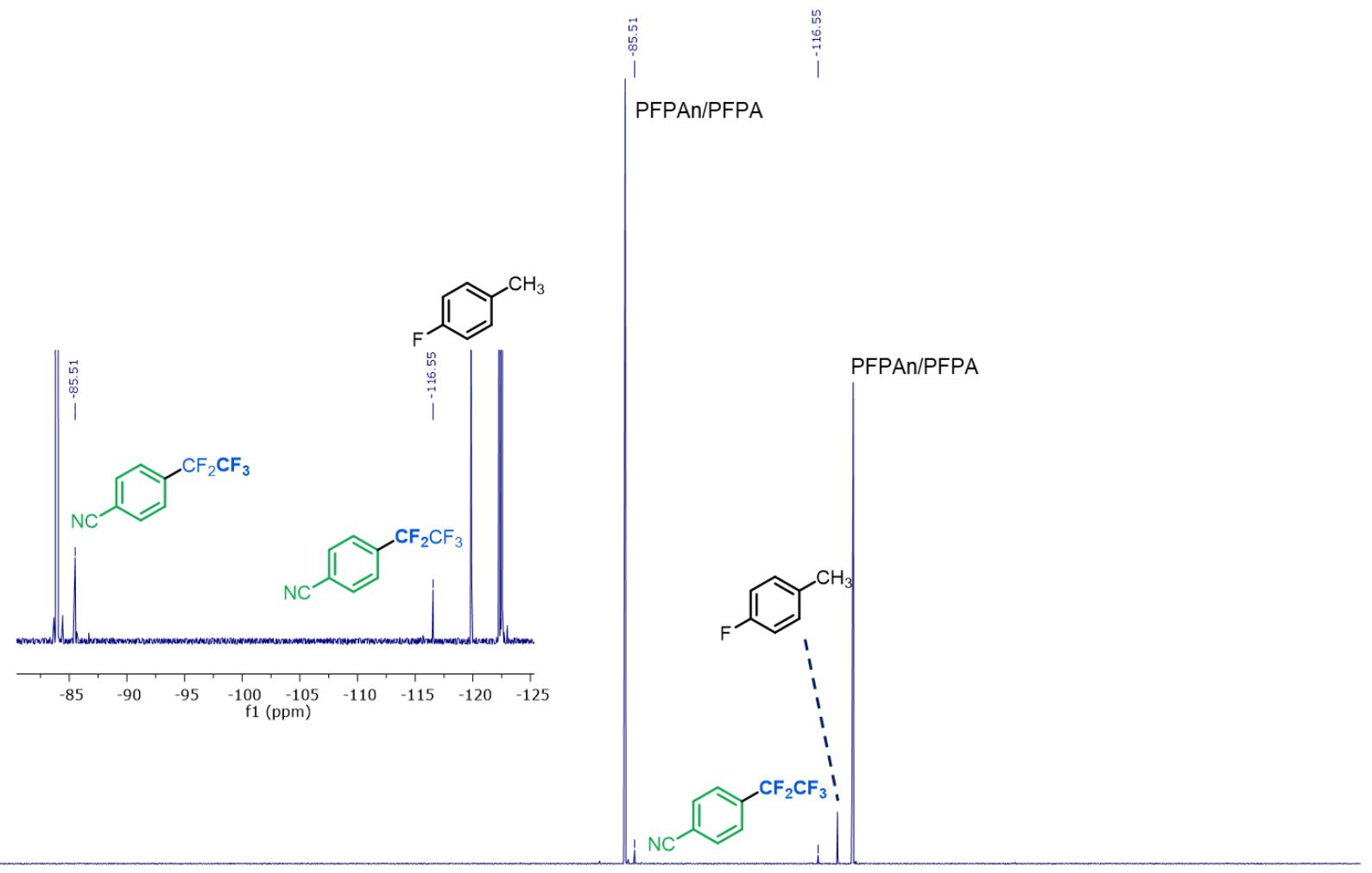

$20 \quad 10$

$\begin{array}{lll}-10 & -20 & -30\end{array}$

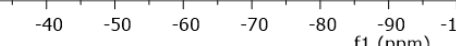

Figure S16. ${ }^{19} \mathrm{~F}$ NMR of crude reaction with 4-fluorotoluene internal standard indicating formation of $1-\mathrm{CF}_{2} \mathrm{CF}_{3}$.

\section{Synthesis of DFAF solution in THF}

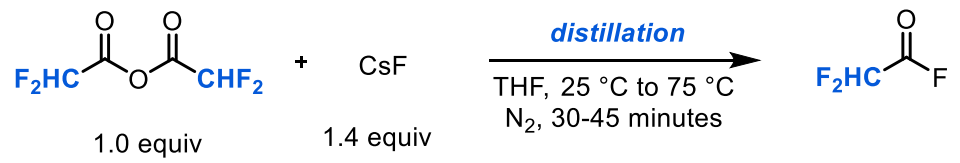

General procedure for the distillation of difluoroacetyl fluoride. A $20 \mathrm{~mL}$ vial containing THF $(7 \mathrm{~mL})$ was placed in the freezer at $-36{ }^{\circ} \mathrm{C}$ and cooled for $15 \mathrm{~min}$. In a $4 \mathrm{~mL}$ vial, a solution of difluoroacetic anhydride $(4.35 \mathrm{~g}, 25 \mathrm{mmol}, 1.0$ equiv) in tetrahydrofuran $(1 \mathrm{~mL})$ was prepared and cooled to $-36{ }^{\circ} \mathrm{C}$ in the glovebox freezer for $15 \mathrm{~min}$. While cooling, solid cesium fluoride ( $5.32 \mathrm{~g}, 35 \mathrm{mmol}, 1.4$ equiv) was added to a $25 \mathrm{~mL}$ round bottom flask equipped with a mediumsized stirbar. Cooled THF $(5 \mathrm{~mL})$ was added to the reaction flask. The cooled solution of anhydride in THF was then added to the flask containing CsF. The flask was quickly sealed with a rubber septum, removed from the glovebox, and allowed to stir at room temperature for $15 \mathrm{~min}$. A short-path distillation apparatus equipped with nitrogen flow, water circulation, and a thermoprobe was fitted to a $25 \mathrm{~mL}$ round bottom collection flask cooled to $0 \stackrel{\circ}{\circ} \mathrm{C}$ in an ice water bath. 
The reaction flask was quickly connected to the distillation apparatus and heated from $25{ }^{\circ} \mathrm{C}$ to $80{ }^{\circ} \mathrm{C}$ in a water bath over a period of 30-45 min. The distillation was determined complete when minimal solvent remained in the reaction flask, the temperature of the gas in the apparatus as determined by the thermoprobe dropped below $45{ }^{\circ} \mathrm{C}$, and condensation into the collection flask slowed dramatically. Once complete, the collection flask containing the product in tetrahydrofuran was quickly sealed with a rubber septum, wrapped securely with black electrical tape, and shortcycled into the glovebox. In a $20 \mathrm{~mL}$ vial, trifluoromethoxybenzene (54 mg, $0.33 \mathrm{mmol}, 1$ equiv in $\mathrm{F}$ ) was weighed as an internal standard, and a portion of the DFAF solution was added via syringe to the vial with total volume recorded. The trifluoromethoxybenzene was treated as approximately $0.05 \mathrm{~mL}$ in volume. After determining the total volume to be $5.4 \mathrm{~mL}$ and ensuring homogeneity, a sample of this solution was transferred to a screw cap NMR tube, diluted with $0.5 \mathrm{~mL}$ tetrahydrofuran, and analyzed via ${ }^{19} \mathrm{~F}$ NMR spectroscopy. The bulk solution was sealed with a Teflon-lined screw cap and stored in the glovebox freezer. The spectrum is shown in Figure S19 with DFAF characterized in situ. Trace difluoroacetic acid is observed in all cases. The concentration of DFAF was calculated as mmol DFAF divided by the volume $(\mathrm{mL})$ of solution as determined by ${ }^{19} \mathrm{~F}$ NMR spectroscopy (Figure S17). A sample calculcation is shown under Figure S12. In some cases, 4-fluorotoluene $(110 \mathrm{mg}, 1 \mathrm{mmol}$, treated as $0.11 \mathrm{~mL}$ in volume) or fluorobenzene (96 mg, $1 \mathrm{mmol}$, treated at $0.095 \mathrm{~mL}$ in volume) was used as the internal standard to assess the yield from DFAF synthesis.

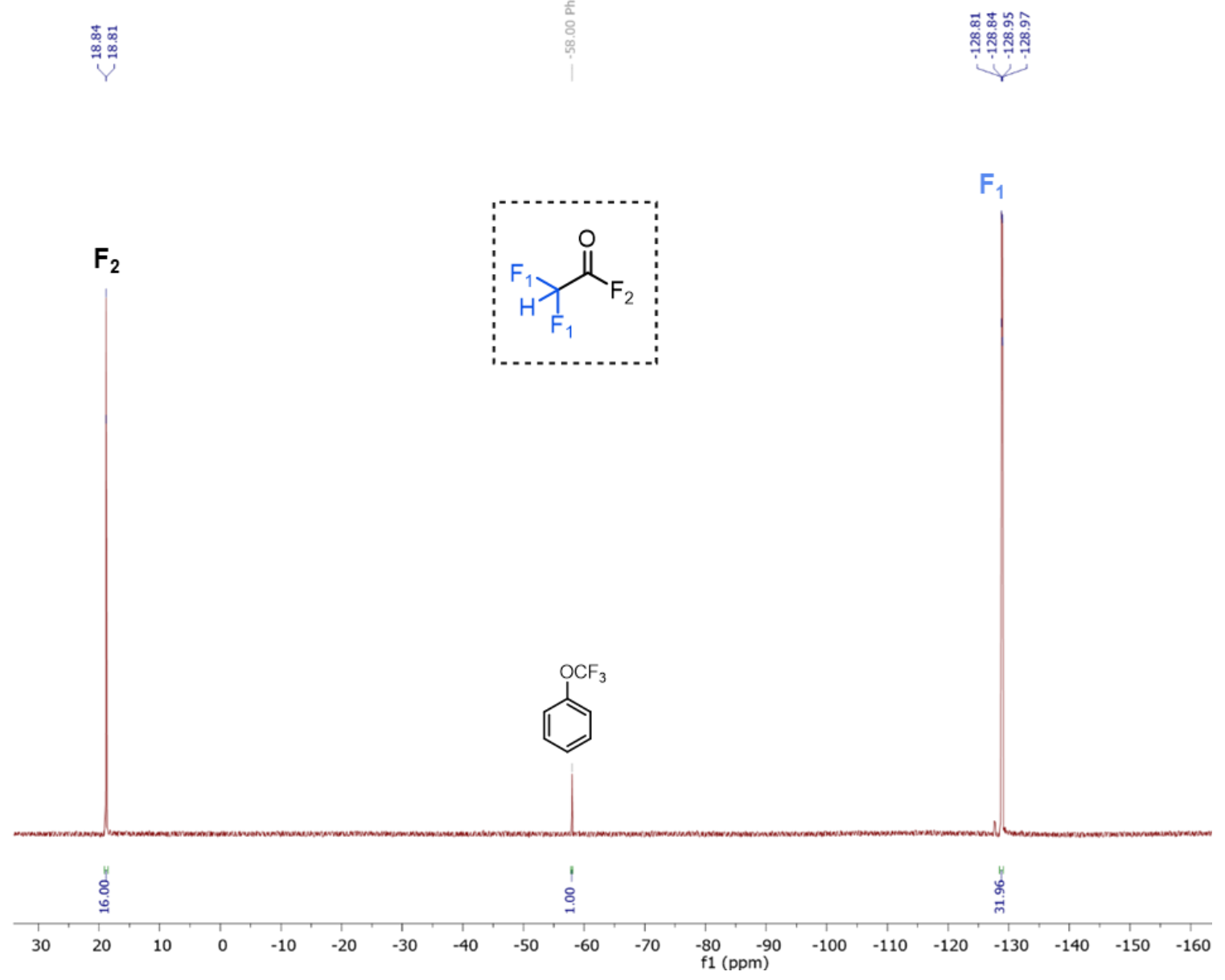

Figure S17. Representative ${ }^{19} \mathrm{~F}$ NMR spectrum obtained after synthesis and distillation of DFAF containing $0.33 \mathrm{mmol}$ of trifluoromethoxybenzene internal standard. ${ }^{19} \mathrm{~F}$ NMR $(377 \mathrm{MHz}$, THF) $\delta 18.82(\mathrm{~m}),-128.89$ (dd, $J=51.9,8.9 \mathrm{~Hz})$. 
Sample calculation of DFAF concentration:

$$
\begin{gathered}
{[16.00+(31.96 / 2)] / 2=15.99 \mathrm{mmol} \text { DFAF }} \\
15.99 \mathrm{mmol} / 5.4 \mathrm{~mL}=2.96 \mathrm{M} \\
15.99 \mathrm{mmol} / 25 \mathrm{mmol}=64 \% \text { yield }
\end{gathered}
$$

THF was identified to be the most suitable reaction solvent and distillation solvent due to the relatively low boiling point of THF and the high solubility of CsF in THF. While a higher boiling solvent, such as mesitylene or xylenes, could in principle enable us to raise the temperature of the catalytic reaction, the poor solubility of $\mathrm{CsF}$ in these solvents limited the acid fluoride generation step in thees media. Further, use of aromatic sovlents, such as toluene, introduces additional challenges in the co-distillation of low boiling DFAF in these high boiling solvents.

\section{Optimization for catalytic aryl difluoromethylation with DFAF}<smiles>CC1(C)COB(c2ccc(C#N)cc2)OC1</smiles>

$1 \mathrm{~b}$

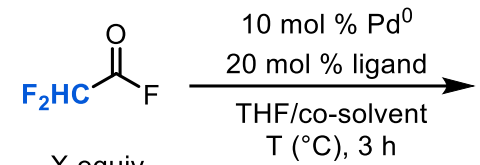

$X$ equiv
$\mathrm{T}\left({ }^{\circ} \mathrm{C}\right), 3 \mathrm{~h}$<smiles>N#Cc1ccc(C(F)F)cc1</smiles>

1

General procedure for the optimization of catalytic decarbonylative aryl difluoromethylation: $\mathrm{A} \mathrm{Pd}^{0}$ source ( $0.005 \mathrm{mmol}, 0.1$ equiv) was dissolved with a phosphine ligand $(0.01 \mathrm{mmol}, 0.2$ equiv) in $0.2 \mathrm{~mL}$ of anhydrous cosolvent and $0.05 \mathrm{~mL}$ THF. The yellow suspension was stirred in a tall $10 \mathrm{~mL}$ vial until homogenous, then $\mathbf{1 b}(10.8 \mathrm{mg}$, $0.05 \mathrm{mmol}, 1$ equiv) was added. To the resulting mixture was added a cold $\left(-36^{\circ} \mathrm{C}\right)$ solution of DFAF $(0.085 \mathrm{~mL}, 0.25$ $\mathrm{mmol}, 2.96 \mathrm{M}$ ) in anhydrous THF. The reaction mixture was then diluted with THF to a total volume of $0.35 \mathrm{~mL}$. The vial was sealed with a Teflon-lined screw cap with a septum (Figure S18), removed from the glovebox, and heated to a given temperature for $3 \mathrm{~h}$. After $3 \mathrm{~h}$, the reaction mixture was allowed to cool to room temperature. To it was added 4-fluorotoluene ( $25 \mu \mathrm{L}, 2.0 \mathrm{M}$ in DCM, 1.0 equiv) as an internal standard, followed by dichloromethane (1.0 mL). An aliquot of the solution was transferred to an NMR tube and analyzed by ${ }^{19} \mathrm{~F}$ NMR spectroscopy. Yields reported are an average of three runs.

Figure S18. Reaction solution in tall $10 \mathrm{~mL}$ vial before heating in THF/toluene.

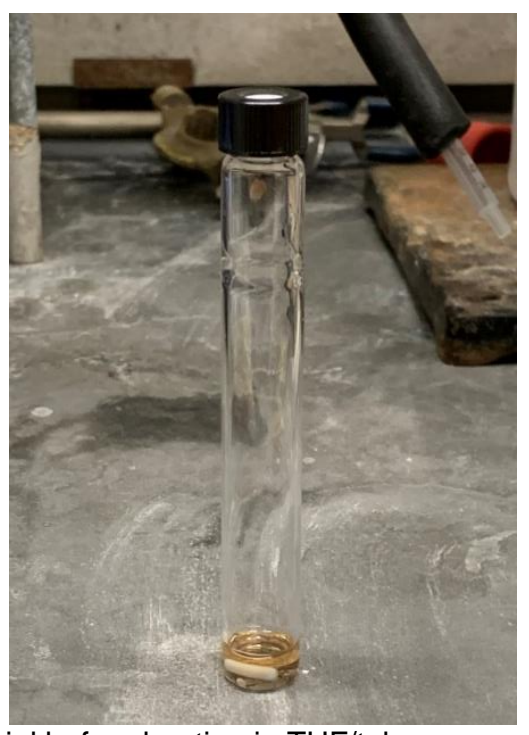




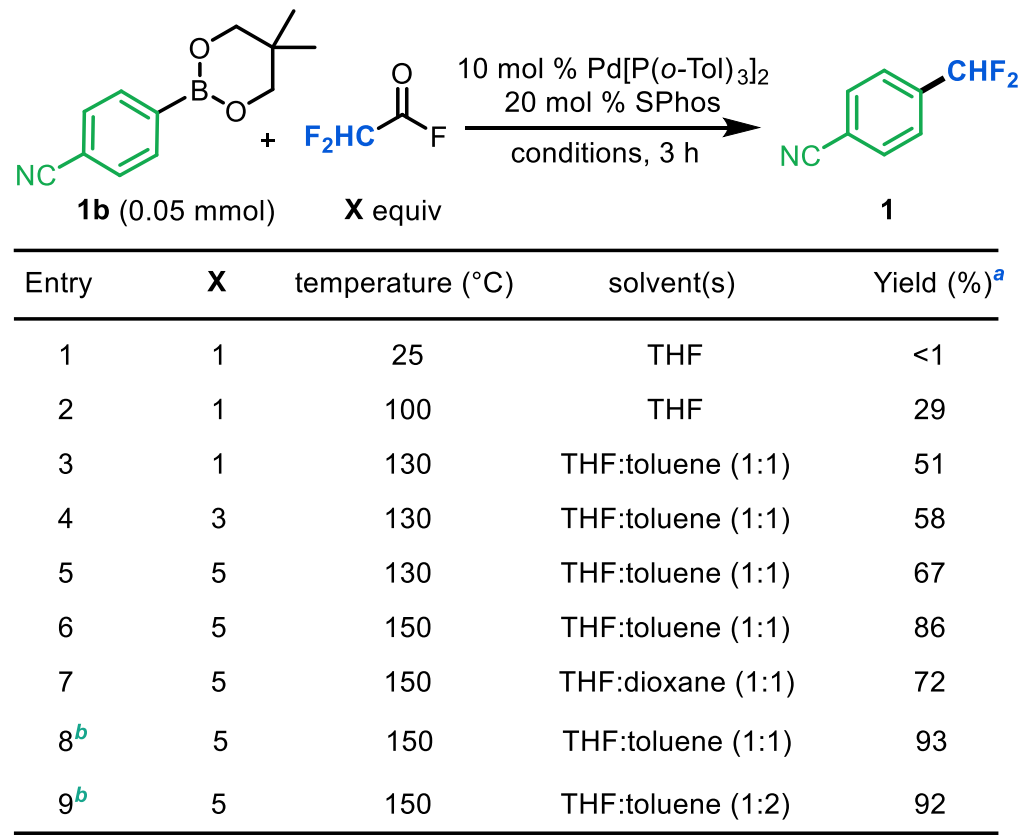

${ }^{a}$ Yields determined by ${ }^{19} \mathrm{~F}$ NMR with internal standard

${ }^{b}$ Reaction was run for $5 \mathrm{~h}$

Table S1. Optimization of reaction temperature, equivalents, and solvent, and time for catalytic decarbonylative difluoromethylation of neopentyl boronate ester $\mathbf{1 b}$.

\begin{tabular}{|c|c|c|c|}
\hline $1 \mathrm{~b}(0.05 \mathrm{mmol})$ & $+{ }_{5}{ }^{2} \mathrm{HC}_{\mathrm{F}}$ & $\begin{array}{l}\stackrel{\mathrm{ol} \% \mathrm{Pd}\left[\mathrm{P}(\mathrm{o}-\mathrm{Tol})_{3}\right]_{2}}{0 \mathrm{~mol} \% \text { SPhos }} \underset{\mathrm{T}}{\stackrel{\text { THF/toluene }}{150{ }^{\circ} \mathrm{C}, 3 \mathrm{~h}}} \text { NC }\end{array}$ & 1 \\
\hline Entry & \multicolumn{2}{|c|}{ Change of reaction conditions } & Yield $(\%)^{a}$ \\
\hline 1 & \multicolumn{2}{|l|}{ none } & 86 \\
\hline 2 & \multicolumn{2}{|c|}{ RuPhos instead of SPhos } & 76 \\
\hline 3 & \multicolumn{2}{|c|}{ DavePhos instead of SPhos } & 78 \\
\hline 4 & \multicolumn{2}{|c|}{ XantPhos instead of SPhos } & $<1$ \\
\hline 5 & \multicolumn{2}{|c|}{ BrettPhos instead of SPhos } & 36 \\
\hline 6 & \multicolumn{2}{|c|}{$\mathrm{Pd}(\mathrm{dba})_{2}$ instead of $\mathrm{Pd}\left[\mathrm{P}(\mathrm{oTol})_{3}\right]_{2}$} & 68 \\
\hline 7 & \multicolumn{2}{|c|}{$4-\mathrm{CNPhB}(\mathrm{OH})_{2}$ instead of $1 \mathrm{a}$} & $<1$ \\
\hline 8 & \multicolumn{2}{|c|}{ 4-CNPhBpin instead of $1 a$} & 29 \\
\hline 9 & \multicolumn{2}{|c|}{$10 \mathrm{~mol} \% \mathrm{Pd}\left[\mathrm{P}(\mathrm{oTol})_{3}\right]_{2} / 10 \mathrm{~mol} \%$ SPhos } & 12 \\
\hline 10 & \multicolumn{2}{|c|}{$5 \mathrm{~mol} \% \mathrm{Pd}\left[\mathrm{P}(\mathrm{oTol})_{3}\right]_{2} / 10 \mathrm{~mol} \%$ SPhos } & 38 \\
\hline 12 & \multicolumn{2}{|l|}{ no SPhos } & $<1$ \\
\hline 13 & \multicolumn{2}{|c|}{ no $\mathrm{Pd}\left[\mathrm{P}(\mathrm{o}-\mathrm{Tol})_{3}\right]_{2}$} & $<1$ \\
\hline
\end{tabular}

${ }^{a}$ Yields determined by ${ }^{19} \mathrm{~F}$ NMR with internal standard

Table S2. Impact of catalyst, nucleophile, and ligand loading on reaction yields. 


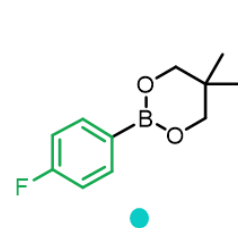

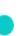

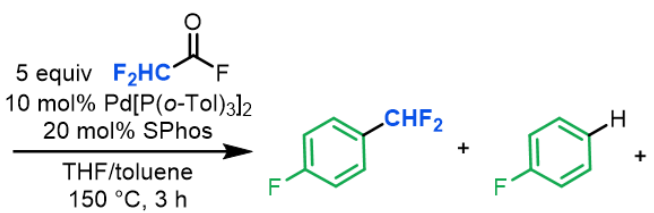

$17 \%$
$14 \%$

C

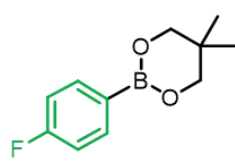

$43 \%$ remaining

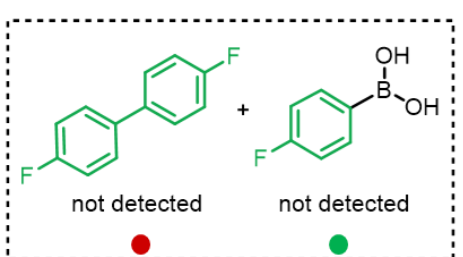

Procedure for determining mass balance of catalytic reaction using 2-(4-fluorophenyl)-5,5-dimethyl-1,3,2dioxaborinane. In a 4-mL vial with stirbar, $\mathrm{Pd}[\mathrm{P}(\mathrm{o}-\mathrm{Tol}) 3]_{2}(21.5 \mathrm{mg}, 0.03 \mathrm{mmol}, 0.6$ equiv) and SPhos $(24.6 \mathrm{mg}, 0.06$ $\mathrm{mmol}, 1.2$ equiv) were combined with $1.2 \mathrm{~mL}$ toluene and $0.3 \mathrm{~mL}$ THF. The mixture was stirred for fifteen minutes. In each of five tall $10 \mathrm{~mL}$ vials equipped with a stir bar, 2-(4-fluorophenyl)-5,5-dimethyl-1,3,2-dioxaborinane (10 mg, 0.05 $\mathrm{mmol}, 1.0$ equiv) was added. To each vial containing substrate $20 \mathrm{~b}$ was added an aliquot $(0.25 \mathrm{~mL})$ of the $\mathrm{Pd} / \mathrm{SPhos}$ mixture. A THF solution of difluoroacetyl fluoride $(0.095 \mathrm{~mL}, 0.25 \mathrm{mmol}, 5$ equiv) was added via syringe to each vial, and the vials were sealed with Teflon-lined screw caps. The vials were removed from the glovebox and heated at 150 ${ }^{\circ} \mathrm{C}$ for $3 \mathrm{~h}$. The reaction mixtures were allowed to cool to room temperature and then were combined. To the combined reaction mixture was added 4-fluorotoluene ( $125 \mu \mathrm{L}, 2.0 \mathrm{M}$ in DCM, 5.0 equiv) as an internal standard. An aliquot (0.4 $\mathrm{mL}$ ) of the solution was transferred to an NMR tube and analyzed via ${ }^{19} \mathrm{~F}$ NMR spectroscopy (Figure S19). The crude NMR yield of 1 -(difluoromethyl)-4-fluorobenzene after $3 \mathrm{~h}$ was $17 \%$ as determined by ${ }^{19} \mathrm{~F}$ NMR. After initial analysis, five additional NMR samples were prepared $(0.4 \mathrm{~mL}$ each), and the following authentic standards were spiked in: 4fluorophenyl boronic acid, 2-(4-fluorophenyl)-5,5-dimethyl-1,3,2-dioxaborinane, 4-fluorobenzene and 4,4 'difluorobiphenyl. Then, ${ }^{19} \mathrm{~F}$ NMR analysis was conducted and the associated spectra are shown below in Figure S20.

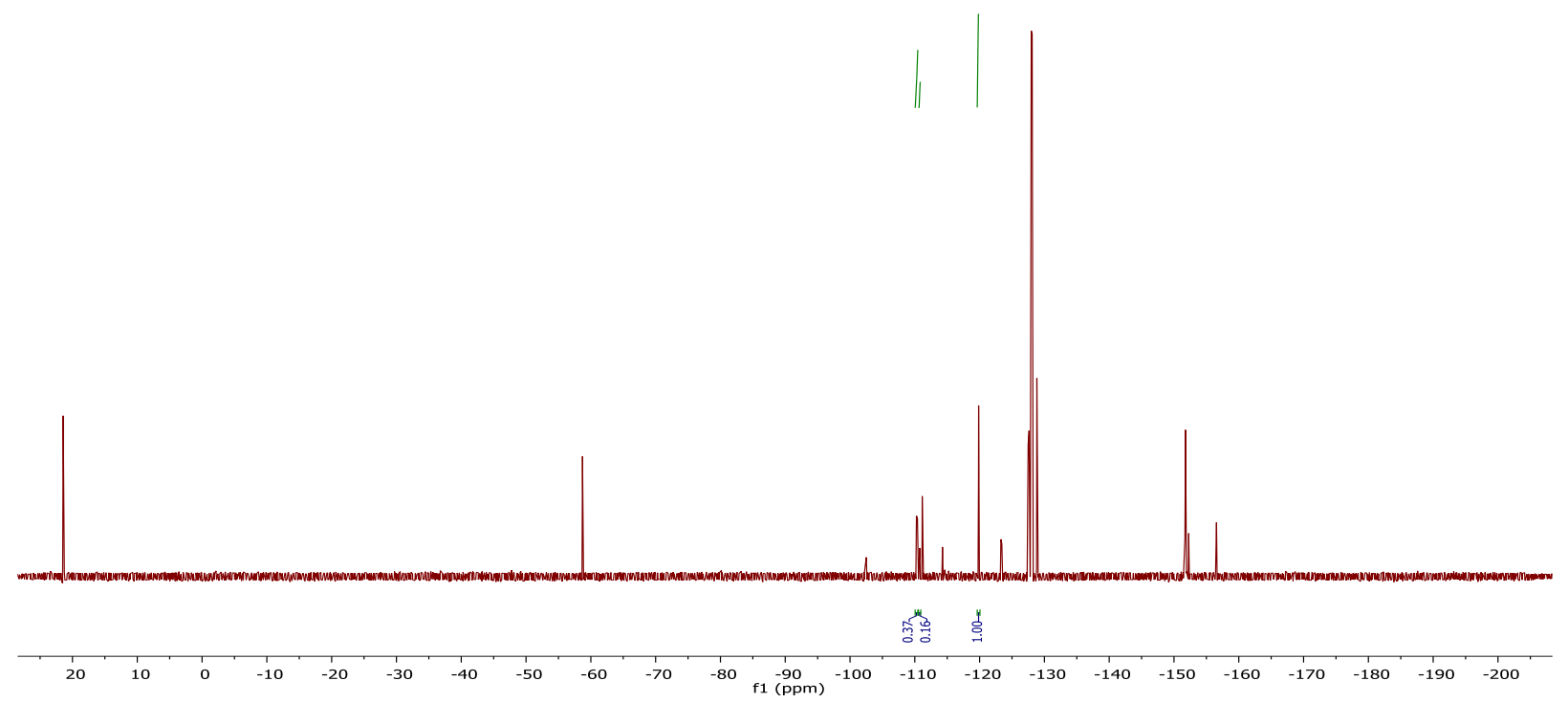

Figure S19. ${ }^{19} \mathrm{~F}$ NMR spectrum obtained from crude reaction of 2-(4-fluorophenyl)-5,5-dimethyl-1,3,2-dioxaborinane under optimized conditions. Reaction was ran for $3 \mathrm{~h}$. 
A. Crude reaction

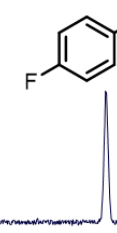

B. $[\mathrm{A}]+4$-fluorophenylboronic acid

B.

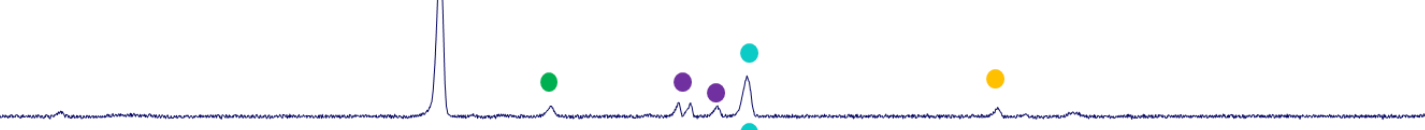

C. $[\mathrm{A}]+2$-(4-fluorophenyl)-5,5-dimethyl-1,3,2-dioxaborinane

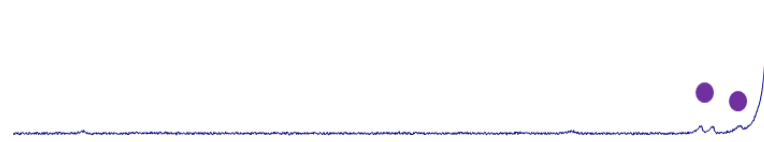

D. $[$ A $]+$ fluorobenzene $+4,4$ '-difluorobiphenyl

D

E. $[$ A $]+4,4$ '-difluorobiphenyl

10

$\Lambda$

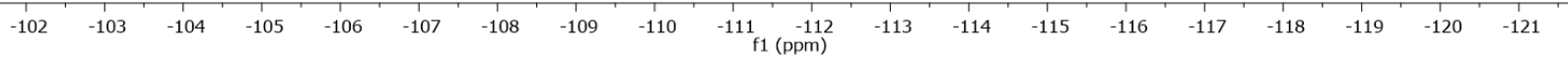

Figure S20. ${ }^{19} \mathrm{~F}$ NMR spectra obtained from spiking authentic samples into the crude reaction of 2-(4-fluorophenyl)5,5-dimethyl-1,3,2-dioxaborinane.

While the mass balance of the reaction cannot be totally accounted for, spiking experiments revealed the presence of $14 \%$ of 4 -fluorobenzene and $43 \%$ of 2 -(4-fluorophenyl)-5,5-dimethyl-1,3,2-dioxaborinane remaining. Similar to the stoichiometric transmetalation experiment using 2-(4-fluorophenyl)-5,5-dimethyl-1,3,2-dioxaborinane, 4-fluorophenyl boronic acid and 4,4'difluorobiphenyl were not observed.<smiles>CC1(C)COB(c2ccc(C#N)cc2)OC1</smiles>

$1 \mathrm{~b}$
5 equiv DFAF

$10 \mathrm{~mol} \% \mathrm{Pd}\left[\mathrm{P}(\mathrm{oTol})_{3}\right]_{2}$

$20 \mathrm{~mol} \%$ SPhos

$20 \mathrm{~mol} \%$ DFAAn

$20 \mathrm{~mol} \%$ equiv $\mathrm{CsF}$

THF/toluene

$150^{\circ} \mathrm{C}$

$3 \mathrm{~h}$

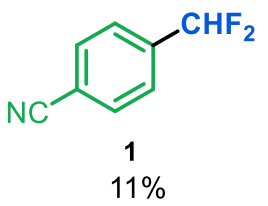

$11 \%$

Procedure generating $\mathrm{CsOCOCHF}_{2}$ in the optimized reaction. In a tall $10 \mathrm{~mL}$ vial equipped with a stir bar, $\mathrm{Pd}[\mathrm{P}(\mathrm{o}-$ Tol) 3$]_{2}$ ( $3.6 \mathrm{mg}, 0.005 \mathrm{mmol}, 0.1$ equiv) and SPhos ( $4.2 \mathrm{mg}, 0.01 \mathrm{mmol}, 0.2$ equiv) were combined in toluene ( $\left.0.2 \mathrm{~mL}\right)$ and THF $(0.05 \mathrm{~mL})$, and the resulting mixture was stirred vigorously for fifteen minutes at room temperature. A THF solution of difluoroacetyl fluoride $(0.25 \mathrm{mmol}, 5$ equiv) was added via syringe. To this solution was added aryl neopentyl 
boronate ester 1b-19b (0.05 mmol, 1.0 equiv), then difluoroacetic anhydride ( $1.7 \mathrm{mg}, 0.01 \mathrm{mmol}, 0.2$ equiv), and CsF ( $1.5 \mathrm{mg}, 0.01 \mathrm{mmol}, 0.2$ equiv). The vial was sealed with a Teflon-lined screw cap, removed from the glovebox, and heated at $150 \stackrel{\circ}{C}$ for $3 \mathrm{~h}$. The reaction mixture was allowed to cool to room temperature. To it was added 4-fluorotoluene (25 $\mu \mathrm{L}, 2.0 \mathrm{M}$ in DCM, 1.0 equiv) as an internal standard, followed by dichloromethane (1.0 mL). An aliquot of the solution was transferred to an NMR tube and analyzed via ${ }^{19} \mathrm{~F}$ NMR spectroscopy. The yield was determined to be $11 \%$ after $3 \mathrm{~h}$ compared to $86 \%$ under standard conditions at $3 \mathrm{~h}$ (see Tables S1 and S2).

\section{Catalysis procedure}

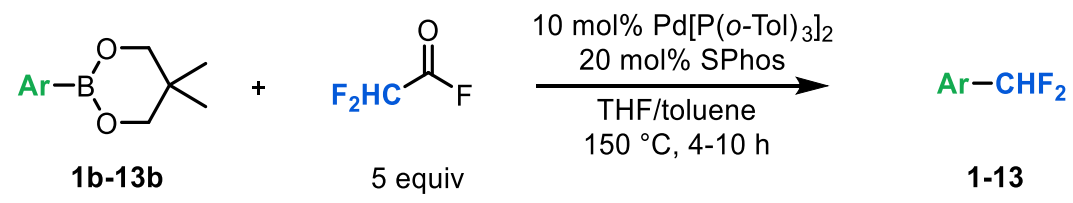

General procedure for the Pd-catalyzed decarbonylative difluoromethylation of aryl neopentyl boronate esters with difluoroacetyl fluoride. In a tall $10 \mathrm{~mL}$ vial equipped with a stir bar, $\mathrm{Pd}\left[\mathrm{P}(0-\mathrm{Tol})_{3}\right]_{2}(3.6 \mathrm{mg}, 0.005 \mathrm{mmol}, 0.1$ equiv) and SPhos (4.2 mg, $0.01 \mathrm{mmol}, 0.2$ equiv) were combined in toluene ( 0.2 mL) and THF (0.05 mL), and the resulting mixture was stirred vigorously for fifteen minutes at room temperature. A THF solution of difluoroacetyl fluoride ( $0.25 \mathrm{mmol}, 5$ equiv) was added via syringe, and the vial was sealed with a Teflon-lined screw cap and shaken gently to ensure homogeneity (total $0.35 \mathrm{~mL}$ volume). To this solution was added aryl neopentyl boronate ester $\mathbf{1 b}-\mathbf{1 9 b}(0.05$ mmol, 1.0 equiv). The vial was sealed with a Teflon-lined screw cap, removed from the glovebox, and heated at 150 ${ }^{\circ} \mathrm{C}$ for $4-10 \mathrm{~h}$. The reaction mixture was allowed to cool to room temperature. To it was added 4-fluorotoluene (25 $\mu \mathrm{L}$, 2.0 $\mathrm{M}$ in DCM, 1.0 equiv) as an internal standard, followed by dichloromethane $(1.0 \mathrm{~mL})$. An aliquot of the solution was transferred to an NMR tube and analyzed via ${ }^{19} \mathrm{~F}$ NMR spectroscopy.

These reactions were observed to be highly sensitive to the purity of all components as well as the reaction vessel used. Efforts to scale the reaction using reaction vials, Schlenk glassware, pressure tubes, and microwave tubes of various volumes resulted in significantly diminished yields. For isolation of products 1-13, six reactions were conducted in parallel to total $0.3 \mathrm{mmol}$ scale. After the reaction time, the reaction mixtures were allowed to cool to room temperature and diluted with $\mathrm{DCM}$ and $\mathrm{Et}_{2} \mathrm{O}$. The mixture was filtered through a pad of silica and concentrated in vacuo. The crude material was then purified via silica gel chromatography using a gradient elution with solvent mixture $A / B$ (\%); $A=15 \%$ chloroform in diethyl ether and $B=$ hexanes, unless otherwise stated. Fractions containing product were collected and carefully concentrated in vacuo to yield pure difluoromethyl arene product.<smiles>N#Cc1ccc(C(F)F)cc1</smiles>

4-(difluoromethyl)benzonitrile (1). Reaction was conducted for isolation scale (6 reactions in parallel, $0.05 \mathrm{mmol}$ scale each) using substrate 1b. Reactions were run for $5 \mathrm{~h}$. Reactions were carefully concentrated to due to the volatity of the product. Purification by flash chromatography on silica gel (0-10\% A/B; B = pentanes) afforded the product as a low-melting white solid (35 mg, 77\% yield). ${ }^{1} \mathrm{H}$ NMR (500 MHz, CDCl $\left.)_{3}\right) \delta .77$ (d, J= $\left.7.9 \mathrm{~Hz}, 2 \mathrm{H}\right), 7.64$ (d, J=7.9 Hz, 2H), 6.69 (t, $J=55.8 \mathrm{~Hz}, 1 \mathrm{H}) .{ }^{19} \mathrm{~F}$ NMR (471 MHz, CDCl $) \delta-113.26(\mathrm{~d}, J=55.8 \mathrm{~Hz}) .{ }^{13} \mathrm{C} \mathrm{NMR}\left(176 \mathrm{MHz}, \mathrm{CDCl}_{3}\right) \delta$ 
138.69 (t, $J=22.9 \mathrm{~Hz}), 132.73,126.54(\mathrm{t}, J=6.1 \mathrm{~Hz}), 118.02,114.93(\mathrm{t}, J=2.0 \mathrm{~Hz}), 113.45(\mathrm{t}, J=240.7 \mathrm{~Hz})$. HRMS (positive ion GC-APCl) calcd. for $\mathrm{C}_{8} \mathrm{H}_{5} \mathrm{~F}_{2} \mathrm{~N}[\mathrm{M}+\mathrm{H}] \mathrm{m} / \mathrm{z}$ 154.0463. Found 154.0457.<smiles>Cc1cc(C(F)F)ccc1C#N</smiles>

4-(difluoromethyl)-2-methylbenzonitrile (2). Reaction was conducted for isolation scale ( 6 reactions in parallel, 0.05 $\mathrm{mmol}$ scale each) using substrate $\mathbf{2 b}$. Reactions were run for $5 \mathrm{~h}$. Purification by flash chromatography on silica gel (0$10 \% \mathrm{~A} / \mathrm{B} ; \mathrm{B}=$ pentanes) afforded the purified product as a colorless oil (34 mg, $68 \%$ yield). ${ }^{1} \mathrm{H}$ NMR $\left(500 \mathrm{MHz}, \mathrm{CDCl}_{3}\right)$ $\delta 7.69(\mathrm{~d}, J=8.0 \mathrm{~Hz}, 1 \mathrm{H}), 7.47(\mathrm{~s}, 1 \mathrm{H}), 7.42(\mathrm{~d}, J=8.0 \mathrm{~Hz}, 1 \mathrm{H}), 6.64(\mathrm{t}, J=55.9 \mathrm{~Hz}, 1 \mathrm{H}), 2.60(\mathrm{~s}, 3 \mathrm{H}) .{ }^{19} \mathrm{~F} \mathrm{NMR}(377$ $\left.\mathrm{MHz}, \mathrm{CDCl}_{3}\right) \delta-113.12(\mathrm{~d}, J=55.9 \mathrm{~Hz}) \cdot{ }^{13} \mathrm{C} \mathrm{NMR}\left(126 \mathrm{MHz}, \mathrm{CDCl}_{3}\right) \delta 142.90,138.48(\mathrm{t}, J=22.6 \mathrm{~Hz}), 133.09,127.46$ (t, $J=6.1 \mathrm{~Hz}$ ), 123.59 (t, $J=6.1 \mathrm{~Hz}$ ), 117.36, $115.26(\mathrm{t}, J=2.1 \mathrm{~Hz}$ ), 113.58 (t, $J=240.3 \mathrm{~Hz}$ ), 20.65. HRMS (positive ion GC-APCl) calcd. for $\mathrm{C}_{9} \mathrm{H}_{7} \mathrm{~F}_{2} \mathrm{~N}[\mathrm{M}+\mathrm{H}] \mathrm{m} / z$ 168.0619. Found 168.0623 .<smiles>O=C(c1ccccc1)c1ccc(C(F)F)cc1</smiles>

(4-(difluoromethyl)phenyl)(phenyl)methanone (3). Reaction was conducted for isolation scale (6 reactions in parallel, $0.05 \mathrm{mmol}$ scale each) using substrate $\mathbf{3 b}$. Reactions were run for $8 \mathrm{~h}$. Purification by flash chromatography on silica gel (0-10\% A/B) afforded the purified product as a white solid (36 mg, $51 \%$ yield). ${ }^{1} \mathrm{H} \mathrm{NMR}\left(500 \mathrm{MHz}, \mathrm{CDCl}_{3}\right)$ $\delta 7.88(\mathrm{~d}, J=7.0 \mathrm{~Hz}, 2 \mathrm{H}), 7.81(\mathrm{~d}, J=7.7 \mathrm{~Hz}, 2 \mathrm{H}), 7.71-7.59$ (multiple peaks, 3H), $7.51(\mathrm{t}, J=6.9 \mathrm{~Hz}, 2 \mathrm{H}), 6.73(\mathrm{t}, J=$ $56.1 \mathrm{~Hz}, 1 \mathrm{H}) .{ }^{19} \mathrm{~F}$ NMR $\left(471 \mathrm{MHz}, \mathrm{CDCl}_{3}\right) \delta-112.12(\mathrm{~d}, J=56.1 \mathrm{~Hz}) .{ }^{13} \mathrm{C}$ NMR $\left(176 \mathrm{MHz}, \mathrm{CDCl}_{3}\right) \delta$ 196.04, 139.88, $137.95(\mathrm{t}, J=22.5 \mathrm{~Hz}), 137.17,133.02,130.37,130.23,114.18$ (t, $J=239.7 \mathrm{~Hz}$ ). HRMS (positive ion GC-APCl) calcd. for $\mathrm{C}_{14} \mathrm{H}_{10} \mathrm{~F}_{2} \mathrm{O}[\mathrm{M}+\mathrm{H}] \mathrm{m} / \mathrm{z} 233.0772$. Found 233.0777.<smiles>CCCC(=O)c1ccc(C(F)F)cc1</smiles>

1-(4-(difluoromethyl)phenyl)butan-1-one (4). Reaction was conducted for isolation scale (6 reactions in parallel, 0.05 mmol scale each) using substrate $4 \mathrm{~b}$ and $15 \mathrm{~mol} \% \mathrm{Pd}\left[\mathrm{P}(\mathrm{o}-\mathrm{Tol})_{3}\right]_{2}$ and $30 \mathrm{~mol} \% \mathrm{SPhos}$. Reactions were run for $10 \mathrm{~h}$. Purification by flash chromatography on silica gel $(0-10 \% \mathrm{~A} / \mathrm{B})$ afforded the purified product as a white solid $(30 \mathrm{mg}$, $50 \%$ yield). Small amounts of grease were present in the purified product but could not be successfully removed via washing with HPLC-grade hexanes. Under the optimized conditions (Entry 1, Table S2), the ${ }^{19} \mathrm{~F}$ NMR yield of product 4 as determined with 4-fluorotoluene internal standard is $37 \%$ after $3 \mathrm{~h} .{ }^{1} \mathrm{H} \mathrm{NMR}\left(500 \mathrm{MHz}, \mathrm{CDCl}_{3}\right) \delta 8.03(\mathrm{~d}, J=8.2$ $\mathrm{Hz}, 2 \mathrm{H}), 7.60(\mathrm{~d}, J=8.1 \mathrm{~Hz}, 2 \mathrm{H}), 6.69(\mathrm{t}, J=56.1 \mathrm{~Hz}, 1 \mathrm{H}), 2.96(\mathrm{t}, J=7.3 \mathrm{~Hz}, 2 \mathrm{H}), 1.78(\mathrm{~m}, 2 \mathrm{H}), 1.01(\mathrm{t}, J=7.4 \mathrm{~Hz}$, $3 \mathrm{H}) .{ }^{19} \mathrm{~F}$ NMR $\left(471 \mathrm{MHz}, \mathrm{CDCl}_{3}\right) \delta-112.52(\mathrm{~d}, J=56.1 \mathrm{~Hz}) .{ }^{13} \mathrm{C} \mathrm{NMR}\left(176 \mathrm{MHz}, \mathrm{CDCl}_{3}\right) \delta 199.79,139.05,138.41(\mathrm{t}$, $J=22.4 \mathrm{~Hz}$ ), 128.50, $126.00(\mathrm{t}, J=6.0 \mathrm{~Hz}), 114.14(\mathrm{t}, J=239.7 \mathrm{~Hz}), 40.88,17.77,13.97$. HRMS (positive ion GCAPCl) calcd. for $\mathrm{C}_{11} \mathrm{H}_{12} \mathrm{~F}_{2} \mathrm{O}[\mathrm{M}+\mathrm{H}] \mathrm{m} / \mathrm{z}$ 199.0929. Found 199.0931 . 
<smiles>O=C1c2ccccc2C(=O)c2cc(C(F)F)ccc21</smiles>

2-(difluoromethyl)anthracene-9,10-dione (5). Reaction was conducted for isolation scale (6 reactions in parallel, 0.05 $\mathrm{mmol}$ scale each) using substrate $\mathbf{5 b}$. Reactions were run for $6 \mathrm{~h}$. Purification by flash chromatography on silica gel (0$10 \% \mathrm{~A} / \mathrm{B}$ ) afforded the purified product as a pale yellow solid ( $55 \mathrm{mg}, 72 \%$ yield). Small amounts of grease were present in the purified product but could not be successfully removed via washing with HPLC-grade hexanes. ${ }^{1} \mathrm{H}$ NMR (500 $\mathrm{MHz}, \mathrm{CDCl}_{3}$ ) $\delta$ 8.46-8.37 (multiple peaks, 2H), 8.32 (dt, $J=6.0,3.1 \mathrm{~Hz}, 2 \mathrm{H}$ ), $7.94(\mathrm{~d}, J=8.0 \mathrm{~Hz}, 1 \mathrm{H}$ ), 7.83 (dt, $J=5.7$, $2.4 \mathrm{~Hz}, 2 \mathrm{H}), 6.79(\mathrm{t}, J=55.8 \mathrm{~Hz}, 1 \mathrm{H}) .{ }^{19} \mathrm{~F}$ NMR $\left(377 \mathrm{MHz}, \mathrm{CDCl}_{3}\right) \delta-112.97(\mathrm{~d}, J=55.8 \mathrm{~Hz}) .{ }^{13} \mathrm{C} \mathrm{NMR}(176 \mathrm{MHz}$, $\left.\mathrm{CDCl}_{3}\right) \delta 182.51,182.38,139.87$ (t, $\left.J=23.0 \mathrm{~Hz}\right), 135.04$ (t, $\left.J=1.7 \mathrm{~Hz}\right), 134.60,133.94,133.45,133.44,130.90$ (t, $J=$ $5.6 \mathrm{~Hz}$ ), 128.12, 127.57, 127.55, 124.97 (t, $J=6.4 \mathrm{~Hz}$ ), 113.60 (t, $J=240.8 \mathrm{~Hz}$ ). HRMS (positive ion GC-APCI) calcd. for $\mathrm{C}_{15} \mathrm{H}_{8} \mathrm{~F}_{2} \mathrm{O}_{2}[\mathrm{M}+\mathrm{H}] \mathrm{m} / \mathrm{z} 259.0565$. Found 259.0571 .<smiles>CCOC(=O)c1ccc(C(F)F)cc1</smiles>

ethyl 4-(difluoromethyl)benzoate (6). Reaction was conducted for isolation scale ( 6 reactions in parallel, $0.05 \mathrm{mmol}$ scale each) using substrate $6 \mathrm{~b}$. Reactions were run for $6 \mathrm{~h}$. Reaction was carefully concentrated to due to volatity of product. Purification by flash chromatography on silica gel $(0-20 \% \mathrm{~A} / \mathrm{B} ; \mathrm{B}=$ pentanes) afforded the purified product as a white solid (35 mg, $58 \%$ yield). ${ }^{1} \mathrm{H} \mathrm{NMR}\left(500 \mathrm{MHz}, \mathrm{CDCl}_{3}\right) \delta 8.13$ (d, J=7.9 Hz, 2H), 7.59 (d, J = 7.9 Hz, 2H), 6.69 (t, $J=55.8 \mathrm{~Hz}, 1 \mathrm{H}), 4.41$ (q, $J=7.1,2 \mathrm{H}), 1.41$ (t $J=7.1,3 \mathrm{H}) .{ }^{19} \mathrm{~F} \mathrm{NMR}\left(471 \mathrm{MHz}, \mathrm{CDCl}_{3}\right) \delta-112.27$ (d, $\left.J=55.8 \mathrm{~Hz}\right)$. ${ }^{13} \mathrm{C}$ NMR $\left(176 \mathrm{MHz}, \mathrm{CDCl}_{3}\right) \delta 165.88,138.47$ (t, $\left.J=22.4 \mathrm{~Hz}\right), 132.81$ (t, $\left.J=2.0 \mathrm{~Hz}\right), 130.03,125.71$ (t, $\left.J=6.0 \mathrm{~Hz}\right)$, $114.16\left(t, J=239.6 \mathrm{~Hz}\right.$ ), 61.47, 14.39. HRMS (positive ion GC-APCl) calcd. for $\mathrm{C}_{10} \mathrm{H}_{10} \mathrm{~F}_{2} \mathrm{O}_{2}[\mathrm{M}+\mathrm{H}] \mathrm{m} / \mathrm{z} 201.0722$. Found 201.0727.<smiles>COC(=O)c1ccc(C(F)F)cc1</smiles>

methyl 4-(difluoromethyl)benzoate (7). Reaction was conducted for isolation scale ( 6 reactions in parallel, $0.05 \mathrm{mmol}$ scale each) using substrate $\mathbf{7 b}$. Reactions were run for $6 \mathrm{~h}$. Reactions were carefully concentrated to due to the volatity of the product. Purification by flash chromatography on silica gel $(0-20 \% \mathrm{~A} / \mathrm{B} ; \mathrm{B}=$ pentanes $)$ afforded the purified product as a white solid (27 mg, 49\% yield). ${ }^{1} \mathrm{H}$ NMR $\left(500 \mathrm{MHz}, \mathrm{CDCl}_{3}\right) \delta 8.13(\mathrm{~d}, J=7.9 \mathrm{~Hz}, 2 \mathrm{H}), 7.59$ (d, J = 7.9 Hz, $2 \mathrm{H}), 6.69(\mathrm{t}, J=56.1 \mathrm{~Hz}, 1 \mathrm{H}), 3.95(\mathrm{~s}, 3 \mathrm{H}) .{ }^{19} \mathrm{~F} \mathrm{NMR}\left(471 \mathrm{MHz}, \mathrm{CDCl}_{3}\right) \delta-112.36$ (d, $\left.J=56.1 \mathrm{~Hz}\right) .{ }^{13} \mathrm{C} \mathrm{NMR}(176 \mathrm{MHz}$, $\left.\mathrm{CDCl}_{3}\right) \delta$ 166.37, 138.59 (t, $\left.J=22.4 \mathrm{~Hz}\right), 132.46,130.09,125.77$ (t, $\left.J=6.0 \mathrm{~Hz}\right), 114.14(\mathrm{t}, J=239.8 \mathrm{~Hz}), 52.52$. HRMS (positive ion GC-APCl) calcd. for $\mathrm{C}_{9} \mathrm{H}_{8} \mathrm{~F}_{2} \mathrm{O}_{2}[\mathrm{M}+\mathrm{H}] \mathrm{m} / \mathrm{z}$ 187.0565. Found 187.0569 . 
<smiles>CCOC(=O)c1cc(C(=O)OCC)cc(C(F)F)c1</smiles>

diethyl 5-(difluoromethyl)isophthalate (8). Reaction was conducted for isolation scale ( 6 reactions in parallel, 0.05 $\mathrm{mmol}$ scale each) using substrate $\mathbf{8 b}$. Reactions were run for $6 \mathrm{~h}$. Purification by flash chromatography on silica gel (0$10 \% \mathrm{~A} / \mathrm{B}$ ) afforded the purified product as a white solid (41 mg, $51 \%$ yield). ${ }^{1} \mathrm{H}$ NMR $\left(401 \mathrm{MHz}, \mathrm{CDCl}_{3}\right) \delta 8.78(\mathrm{~s}, 1 \mathrm{H})$, 8.48-8.07 (multiple peaks, 2H), $6.73(\mathrm{t}, J=55.4 \mathrm{~Hz}, 1 \mathrm{H}), 4.43(\mathrm{q}, J=7.1 \mathrm{~Hz}, 4 \mathrm{H}), 1.42(\mathrm{t}, J=7.1 \mathrm{~Hz}, 6 \mathrm{H}) .{ }^{19} \mathrm{~F} \mathrm{NMR}$ (377 MHz, CDCl 3 ) $\delta-111.73$ (d, $J=55.4 \mathrm{~Hz}$ ). $\left.{ }^{13} \mathrm{C} \mathrm{NMR} \mathrm{(176} \mathrm{MHz,} \mathrm{CDCl} 3\right) \delta 165.05,135.34$ (t, $\left.J=23.3 \mathrm{~Hz}\right), 132.77$ (t, $J=1.7 \mathrm{~Hz}$ ), 131.89, $130.86(\mathrm{t}, J=6.0 \mathrm{~Hz}), 113.69(\mathrm{t}, J=240.3 \mathrm{~Hz}), 61.89,14.43$. HRMS (positive ion GC-APCl) calcd. for $\mathrm{C}_{13} \mathrm{H}_{14} \mathrm{~F}_{2} \mathrm{O}_{4}[\mathrm{M}+\mathrm{H}] \mathrm{m} / \mathrm{z} 273.0933$. Found 273.0935 .

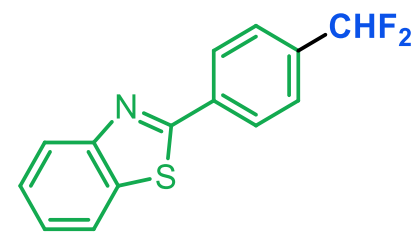

2-(4-(difluoromethyl)phenyl)benzo[d]thiazole (9). Reaction was conducted for isolation scale (6 reactions in parallel, $0.05 \mathrm{mmol}$ scale each) using substrate $9 \mathrm{~b}$. Reactions were run for $8 \mathrm{~h}$. Purification by flash chromatography on silica gel $(0-10 \% \mathrm{~A} / \mathrm{B})$ afforded the purified product as a white solid $(36 \mathrm{mg}, 46 \%$ yield). Small amounts of grease were present in the purified product but could not be successfully removed via washing with HPLC-grade hexanes. ${ }^{1} \mathrm{H}$ NMR $\left(401 \mathrm{MHz}, \mathrm{CDCl}_{3}\right) \delta 8.19(\mathrm{~d}, J=8.2 \mathrm{~Hz}, 2 \mathrm{H}), 8.10(\mathrm{~d}, J=8.2 \mathrm{~Hz}, 1 \mathrm{H}), 7.93(\mathrm{~d}, J=7.9 \mathrm{~Hz}, 1 \mathrm{H}), 7.65(\mathrm{~d}, J=8.2 \mathrm{~Hz}, 2 \mathrm{H})$, 7.52 (ddd, $J=8.4,7.2,1.3 \mathrm{~Hz}, 1 \mathrm{H}$ ), 7.42 (ddd, $J=8.3,7.2,1.2 \mathrm{~Hz}, 1 \mathrm{H}), 6.72(\mathrm{t}, J=56.2 \mathrm{~Hz}, 1 \mathrm{H}) .{ }^{19} \mathrm{~F} \mathrm{NMR}(377 \mathrm{MHz}$, $\left.\mathrm{CDCl}_{3}\right) \delta-111.85(\mathrm{~d}, J=56.2 \mathrm{~Hz}) .{ }^{13} \mathrm{C} \mathrm{NMR}\left(176 \mathrm{MHz}, \mathrm{CDCl}_{3}\right) \delta 166.80,154.22,136.68(\mathrm{t}, J=22.5 \mathrm{~Hz}), 135.94$, 135.31, 127.97, 126.71, 126.45 (t, $J=6.1 \mathrm{~Hz}$ ), 125.76, 123.66, 121.86, 114.32 (t, $J=239.4 \mathrm{~Hz}$ ). HRMS (positive ion GC-APCl) calcd. for $\mathrm{C}_{14} \mathrm{H}_{9} \mathrm{~F}_{2} \mathrm{NS}[\mathrm{M}+\mathrm{H}] \mathrm{m} / \mathrm{z} 262.0497$. Found 262.0503.<smiles>Cc1nc(-c2ccc(C(F)F)cc2)no1</smiles>

3-(4-(difluoromethyl)phenyl)-5-methyl-1,2,4-oxadiazole (10). Reaction was conducted for isolation scale (6 reactions in parallel, $0.05 \mathrm{mmol}$ scale each) using substrate 10b. Reactions were run for $10 \mathrm{~h}$. Purification by flash chromatography on silica gel $(0-10 \% \mathrm{~A} / \mathrm{B})$ afforded the purified product as a white solid $\left(10 \mathrm{mg}, 15 \%\right.$ yield). ${ }^{1} \mathrm{H}$ NMR $\left(500 \mathrm{MHz}, \mathrm{CDCl}_{3}\right) \delta 8.16(\mathrm{~d}, J=8.0 \mathrm{~Hz}, 2 \mathrm{H}), 7.63(\mathrm{~d}, J=8.1 \mathrm{~Hz}, 2 \mathrm{H}), 6.70(\mathrm{t}, J=56.2 \mathrm{~Hz}, 1 \mathrm{H}), 2.67(\mathrm{~s}, 3 \mathrm{H}) .{ }^{19} \mathrm{~F} \mathrm{NMR}$ $\left(471 \mathrm{MHz}, \mathrm{CDCl}_{3}\right) \delta-111.78(\mathrm{~d}, J=56.2 \mathrm{~Hz}) .{ }^{13} \mathrm{C} \mathrm{NMR}\left(176 \mathrm{MHz}, \mathrm{CDCl}_{3}\right) \delta 177.02,167.85,136.96(\mathrm{t}, J=22.5 \mathrm{~Hz})$, 129.30 (t, $J=1.8 \mathrm{~Hz}$ ), 127.83, 126.27 (t, $J=6.1 \mathrm{~Hz}$ ), 114.30 (t, $J=239.5 \mathrm{~Hz}$ ), 12.56. HRMS (positive ion GC-APCI) calcd. for $\mathrm{C}_{10} \mathrm{H}_{8} \mathrm{~F}_{2} \mathrm{~N}_{2} \mathrm{O}[\mathrm{M}+\mathrm{H}] \mathrm{m} / \mathrm{z} 211.0677$. Found 211.0680 . 
<smiles>CC(C)S(=O)(=O)c1ccc(C(F)F)cc1</smiles>

1-(difluoromethyl)-4-(isopropylsulfonyl)benzene (11). Reaction was conducted for isolation scale (6 reactions in parallel, $0.05 \mathrm{mmol}$ scale each) using substrate 11b. Reactions were run for $6 \mathrm{~h}$. Purification by flash chromatography on silica gel (0-20\% A/B) afforded the purified product as a white solid (41 mg, $58 \%$ yield). $\left.{ }^{1} \mathrm{H} \mathrm{NMR} \mathrm{(500} \mathrm{MHz,} \mathrm{CDCl}_{3}\right)$ $\delta 7.99(\mathrm{~d}, J=8.1,2 \mathrm{H}), 7.72(\mathrm{~d}, J=8.1 \mathrm{~Hz}, 2 \mathrm{H}), 6.73(\mathrm{t}, J=55.9 \mathrm{~Hz}, 1 \mathrm{H}), 3.21$ (hept, $J=6.8 \mathrm{~Hz}, 1 \mathrm{H}), 1.31$ (d, $J=6.8$ $\mathrm{Hz}, 6 \mathrm{H}) .{ }^{19} \mathrm{~F}$ NMR $\left(471 \mathrm{MHz}, \mathrm{CDCl}_{3}\right) \delta-113.19$ (d, $\left.J=55.9 \mathrm{~Hz}\right) .{ }^{13} \mathrm{C} \mathrm{NMR}\left(176 \mathrm{MHz}, \mathrm{CDCl}_{3}\right) \delta 139.57$ (t, $\left.J=1.7 \mathrm{~Hz}\right)$, $139.53(\mathrm{t}, J=22.7 \mathrm{~Hz}$ ), 129.75, 126.55 (t, $J=6.0 \mathrm{~Hz}$ ), 113.56 (t, $J=240.6 \mathrm{~Hz}$ ), 55.81, 15.80. HRMS (positive ion GCAPCl) calcd. for $\mathrm{C}_{10} \mathrm{H}_{12} \mathrm{~F}_{2} \mathrm{O}_{2} \mathrm{~S}[\mathrm{M}+\mathrm{H}] \mathrm{m} / \mathrm{z} 235.0599$. Found 235.0607 .<smiles>CN(C)S(=O)(=O)c1ccc(C(F)F)cc1</smiles>

4-(difluoromethyl)-N,N-dimethylbenzenesulfonamide (12). Reaction was conducted for isolation scale (6 reactions in parallel, $0.05 \mathrm{mmol}$ scale each) using substrate $\mathbf{1 2 b}$. Reactions were run for $6 \mathrm{~h}$. Purification by flash chromatography on silica gel (0-50\% A/B) afforded the purified product as a colorless oil (36 mg, $51 \%$ yield). ${ }^{1} \mathrm{H}$ NMR $\left(500 \mathrm{MHz}, \mathrm{CDCl}_{3}\right)$ $\delta 7.88(\mathrm{~d}, J=8.0 \mathrm{~Hz}, 2 \mathrm{H}), 7.70(\mathrm{~d}, J=8.0 \mathrm{~Hz}, 2 \mathrm{H}), 6.72(\mathrm{t}, J=55.9 \mathrm{~Hz}, 1 \mathrm{H}), 2.74(\mathrm{~s}, 6 \mathrm{H}) .{ }^{19} \mathrm{~F} \mathrm{NMR}\left(471 \mathrm{MHz}, \mathrm{CDCl}_{3}\right)$ $\delta-112.68(\mathrm{~d}, \mathrm{~J}=55.9 \mathrm{~Hz}) .{ }^{13} \mathrm{C} \mathrm{NMR}\left(176 \mathrm{MHz}, \mathrm{CDCl}_{3}\right) \delta 138.54(\mathrm{t}, J=22.8 \mathrm{~Hz}), 138.21(\mathrm{t}, J=2.0 \mathrm{~Hz}), 128.24,126.53$ (t, $J=6.0 \mathrm{~Hz}$ ), 113.67 (t, $J=240.3 \mathrm{~Hz}$ ), 37.97. HRMS (positive ion GC-APCl) calcd. for $\mathrm{C}_{9} \mathrm{H}_{11} \mathrm{~F}_{2} \mathrm{NO}_{2} \mathrm{~S}[\mathrm{M}+\mathrm{H}] \mathrm{m} / \mathrm{z}$ 236.0551. Found 236.0556.<smiles>CCCN(CCC)S(=O)(=O)c1ccc(C(F)F)cc1</smiles>

4-(difluoromethyl)-N,N-dipropylbenzenesulfonamide (13). Reaction was conducted for isolation scale (6 reactions in parallel, $0.05 \mathrm{mmol}$ scale each) using substrate 13b. Reactions were run for $6 \mathrm{~h}$. Purification by flash chromatography on silica gel (0-20\% A/B) afforded the purified product as a white solid (45 mg, $52 \%$ yield). $\left.{ }^{1} \mathrm{H} \mathrm{NMR} \mathrm{(500} \mathrm{MHz}, \mathrm{CDCl}_{3}\right)$ $\delta 7.90$ (d, $J=7.9 \mathrm{~Hz}, 2 \mathrm{H}), 7.65(\mathrm{~d}, J=7.9 \mathrm{~Hz}, 2 \mathrm{H}), 6.70(\mathrm{t}, J=56.0 \mathrm{~Hz}, 1 \mathrm{H}), 3.10$ (t $J=7.6,4 \mathrm{H}), 1.61-1.51(\mathrm{~m}, 4 \mathrm{H})$, $0.88(\mathrm{t}, J=7.4,6 \mathrm{H}) .{ }^{19} \mathrm{~F}$ NMR $\left(471 \mathrm{MHz}, \mathrm{CDCl}_{3}\right) \delta-112.51$ (d, $\left.J=56.0 \mathrm{~Hz}\right) .{ }^{13} \mathrm{C}$ NMR $\left(176 \mathrm{MHz}, \mathrm{CDCl}_{3}\right) \delta 142.60$, 137.90 (t, $J=22.7 \mathrm{~Hz}), 127.40,126.29(\mathrm{t}, J=6.0 \mathrm{~Hz}$ ), 113.57 (t, $J=240.2 \mathrm{~Hz}$ ), 49.98, 21.97, 11.12. HRMS (positive ion GC-APCl) calcd. for $\mathrm{C}_{13} \mathrm{H}_{19} \mathrm{~F}_{2} \mathrm{NO}_{2} \mathrm{~S}[\mathrm{M}+\mathrm{H}] \mathrm{m} / \mathrm{z} 292.1177$. Found 292.1182.

\section{Other substrates explored}

Fluorine- and fluoroalky-substituted ArBneo substrates $\mathbf{1 4 b}$-18b were also explored. ${ }^{19} \mathrm{~F}$ NMR spectroscopic analysis of the crude reaction mixtures implicates the formation of the $\mathrm{ArCHF}_{2}$ products 14-18. The ${ }^{19} \mathrm{~F}$ NMR chemical shifts that are assigned as $-\mathbf{C H F}_{2}$ resonance for each product are listed below, along with a ${ }^{19} \mathrm{~F}$ NMR yields (versus 4 fluorotoluene as an internal standard). None of these products were isolated due to their volatility. 
<smiles>CS(=O)(=O)c1cc(C(F)F)cc(C(F)(F)F)c1</smiles>

1-(difluoromethyl)-3-(methylsulfonyl)-5-(trifluoromethyl)benzene (14). The reaction was conducted as a single run using $14 \mathrm{~b}$, and the yield of 14 was determined by ${ }^{19} \mathrm{~F}$ NMR spectroscopy with 4-fluorotoluene as an internal standard. Reaction time: $4 \mathrm{~h}$; yield: $65 \% .{ }^{19} \mathrm{~F}$ NMR $(377 \mathrm{MHz}) \delta-113.77$ (d, $\left.J=56.4 \mathrm{~Hz}\right)$.<smiles>FC(F)c1cc(C(F)(F)F)cc(C(F)(F)F)c1</smiles>

1-(difluoromethyl)-3,5-bis(trifluoromethyl)benzene (15). The reaction was conducted as a single run using $\mathbf{1 5 b}$, and the yield of 15 was determined by ${ }^{19} \mathrm{~F}$ NMR spectroscopy with 4-fluorotoluene as an internal standard. Reaction time: $4 \mathrm{~h}$; yield: $94 \%$. A second trial using substrate $15 \mathrm{~b}$ yielded $86 \%$ of $15 .{ }^{19} \mathrm{~F}$ NMR $(471 \mathrm{MHz}) \delta-113.64(\mathrm{~d}, J=55.5 \mathrm{~Hz})$.<smiles>FC(F)c1ccc(C(F)(F)F)cc1</smiles>

1-(difluoromethyl)-4-(trifluoromethyl)benzene (16). The reaction was conducted as a single run using $16 \mathrm{~b}$, and the yield of $\mathbf{1 6}$ was determined by ${ }^{19} \mathrm{~F}$ NMR spectroscopy with trifluoromethoxybenzene as an internal standard. Reaction time: $4 \mathrm{~h}$; yield: $58 \%$. A second trial using substrate $16 \mathrm{~b}$ yielded $50 \%$ of $16 .{ }^{19} \mathrm{~F}$ NMR $(471 \mathrm{MHz}) \delta-113.13(\mathrm{~d}, J=56.1$ $\mathrm{Hz})$.<smiles>Fc1ccc(C(F)F)cc1F</smiles>

1-(difluoromethyl)-4-(trifluoromethyl)benzene (17). The reaction was conducted as a single run using $\mathbf{1 7 b}$, and the yield of $\mathbf{1 7}$ was determined by ${ }^{19} \mathrm{~F}$ NMR trifluoromethoxybenzene as an internal standard. Reaction time: $4 \mathrm{~h}$; yield: $60 \% .{ }^{19} \mathrm{~F}$ NMR $(377 \mathrm{MHz}) \delta-110.39(\mathrm{~d}, J=55.9 \mathrm{~Hz})$.<smiles>FC(F)c1ccc(OC(F)(F)F)cc1</smiles>

1-(difluoromethyl)-4-(trifluoromethyl)benzene (18). The reaction was conducted as a single run using $\mathbf{1 8 b}$, and the yield of $\mathbf{1 8}$ was determined ${ }^{19} \mathrm{~F}$ NMR spectroscopy with 4-fluorotoluene as an internal standard. Reaction time: $4 \mathrm{~h}$; yield: $69 \% .{ }^{19} \mathrm{~F}$ NMR $(471 \mathrm{MHz}) \delta-117.08(\mathrm{~d}, J=55.6 \mathrm{~Hz})$. 

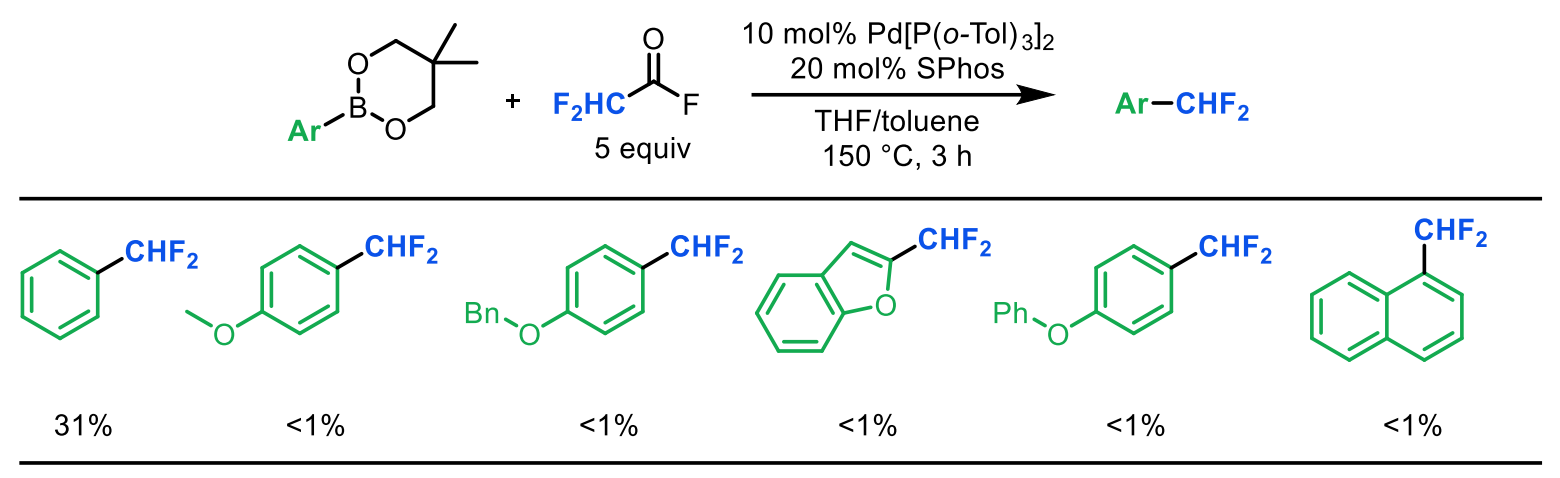

Table S3. Other substrates explored for palladium-catalyzed difluoromethylation using difluoroacetyl fluoride.

\section{Computational Methods}

A parallel molecular mechanics ( $M M)$ and the advanced quantum mechanical (QM) calculations of complexes, intermediates, transition states and products were carried out using Jaguar programs, as implemented in Schrödinger Material Suite $2019-1^{9}$ as well as Gaussian software. ${ }^{10}$ The MM based conformational search was carried out on the geometry of the pre-complexes and final products to obtain a preliminary insight into the different possible conformers. Top unique conformers were selected and were further optimized applying density functional theory (DFT) calculations. The geometry optimizations of all the structures were performed using the M06 functional with the combined LANL2DZ basis set for $\mathrm{Pd}$, and $\mathrm{P}$ atoms, and $6-311 \mathrm{G}^{* *}$ is selected for $\mathrm{C}, \mathrm{H}, \mathrm{O}$ and $\mathrm{F}$ atoms. The polarization functions of $\mathrm{Pd}(\zeta \mathrm{f})$ $=1.472,14$, and $\mathrm{P}(\zeta \mathrm{d})=0.340$ were also included. ${ }^{11}$ The optimized geometries were further confirmed by frequency calculations at the same level of theory as minima (zero imaginary frequencies) or transition states (one imaginary frequency). The thermochemical quantities were analyzed at both $298 \mathrm{~K}$ and $363 \mathrm{~K}$ (the experimental temperatures), and the intrinsic reaction coordinate ${ }^{12}$ (IRC) was applied to obtain the minima of products and the starting materials on either side of each optimized transition state in gas phase. The energies were further corrected with BPV86 functional using larger basis sets and different solvation models using the self-consistent reaction field (SCRF) method with the conductor-like polarizable (CPCM) model and UAHF radii ${ }^{13}$ applying the default solvent parameters for THF (the applied experimental solvent) using Gaussian 09 package on Compute Canada systems and Great Lakes implemented at University of Michigan. The applied methods were chosen based on balancing computational time and accuracy to properly treat the key dispersion interactions. The structural visualizations were carried out using GaussView v5.0.8.4. To analyze in detail the electronic and structural perspectives, natural bond orbital analysis (NBO) using the same level of theory as solvation models as well as non-covalent interaction $(\mathrm{NCl})$ analysis was performed. ${ }^{14}$ We limited calculations to the $\mathrm{C}-\mathrm{C}$ bond cleavage/carbonyl reorientation process, which is a key step in the potential energy surface for the carbonyl de-insertion reaction. Optimal structures of intermediates in the decarbonylation process were found via conformational sampling of difluoroacetic anhydride and trifluoroacetic anhydride complexes. The most promising conformers were further optimized by the M06 functional with the combined LANL2DZ basis set for Pd, and $\mathrm{P}$ atoms, and $6-311 \mathrm{G}(\mathrm{d}, \mathrm{p})$ for $\mathrm{C}, \mathrm{H}, \mathrm{O}$ and $\mathrm{F}$ atoms for further structural and electronic analysis (distortion interactions, non-covalent interactions, electrostatic potential surfaces). To account for the entropic contributions in the activation free energy barrier, we also computationally analyzed the temperature-dependent activation barrier of decarbonylation process at a high experimental temperature $(363 \mathrm{~K})$. The same trends are observed at this higher temperature and qualitatively reflected the experimental findings. 


\section{Computational Data and Discussion}

\section{A. Molecular Mechanics (MM)-based conformational analysis}

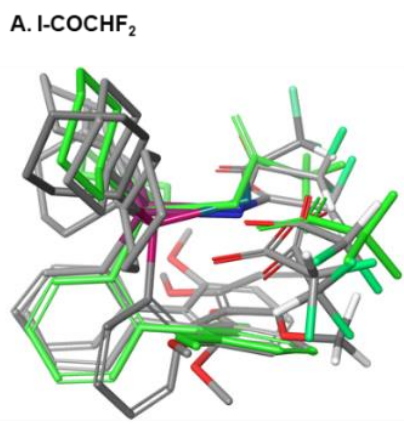

C. I- $-\mathrm{COCF}_{3}$

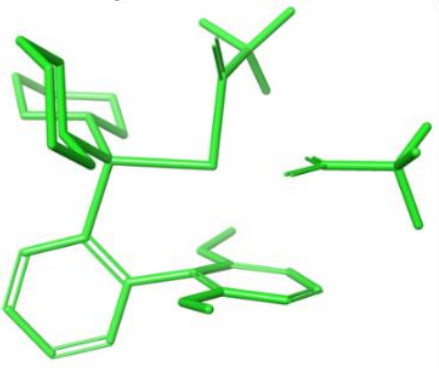

B. $\mathrm{TS} 1-\mathrm{CHF}_{2}$

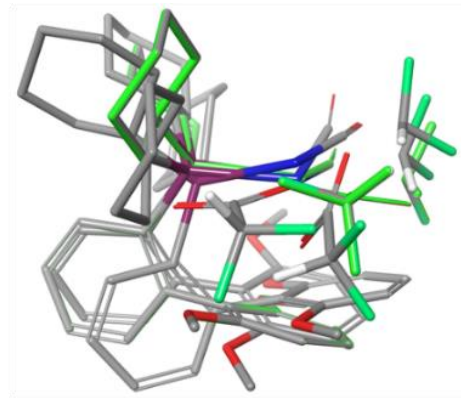

D. TS1-CF

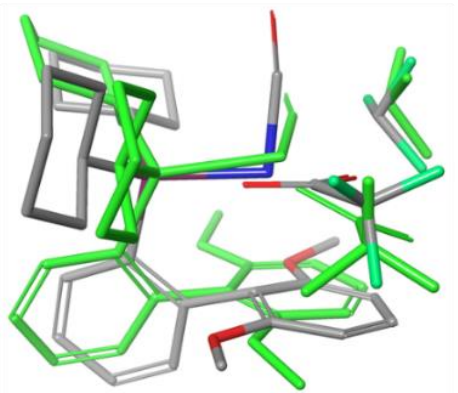

Figure S21. The superimposed conformers of $\mathbf{I}-\mathbf{C O C H F}_{2}$ and $\mathbf{I}-\mathbf{C O C F}_{3}$ and transition state derived complexes, TS1$\mathbf{C H F}_{2}$ and $\mathbf{T S}_{1}-\mathbf{C F}_{3}$, determined to be within $10 \mathrm{kcal} / \mathrm{mol}$ of the global minimum. The lowest energy conformer in each case is shown in green.

MM-based conformational analyses suggest that $\mathbf{I}_{-} \mathbf{C O C F}_{3}$ (Figure S21, C) exists within a narrower conformational range than $\mathrm{I}_{-} \mathrm{COCHF}_{2}$. Few optimized conformers of $\mathrm{I}_{-} \mathbf{C O C F}_{3}$ were found $2-10 \mathrm{kcal} / \mathrm{mol}$ above the global minimum with low conformational diversity (as indicated by the green conformer of I-COCHF 2 (Fig. S21, C), that is nearly conformationally indistinct and overlapped with a second conformer in gray. For I-COCHF 2 , a large mixture of thermally accessible conformational families is present and could be reactive under the applied conditions (Fig. S21, A). We propose that this larger conformational diversity near the energetic minimum relates to the presence of an acidic

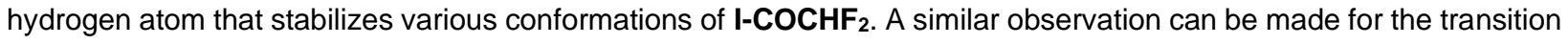
states TS1-R $\mathbf{R}_{\mathbf{F}}$ (Figure S21, B and D), in which a greater number of low energy conformations are present for $\mathbf{T S}^{-\mathbf{C H F}_{2}}$ compared to $\mathbf{T S 1}_{-} \mathbf{C F}_{3}$. From the DFT-based optimized conformers, the two lowest energy conformers (I-CORF A and B and their associated transition states) were selected for further computational analysis.

Energetics were calculated only for the 1,1-de-insertion reaction of I-CORF to form (CO)Pd-RF proceeding through TS1$\mathbf{R}_{\mathbf{F}}$ as this is proposed to be the more demanding step for the decarbonylation process (rather than the release of $\mathrm{CO}$ ). This in agreement with our stoichiometric results, in which we do not observe intermediate (CO)Pd-RF for either - $\mathrm{CF}_{3}$ or $-\mathrm{CHF}_{2}$. 
A.
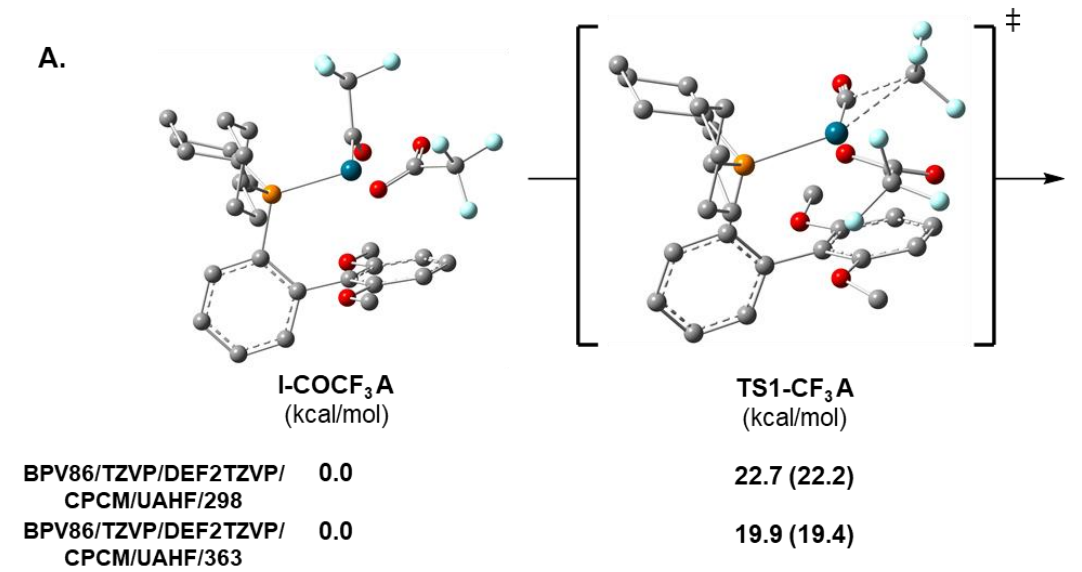

22.7 (22.2)

19.9 (19.4)

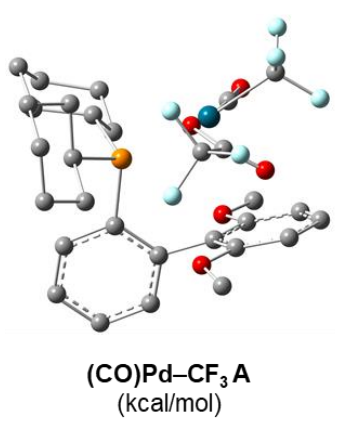

1.3 (1.4)

$-1.6(-1.4)$

B.
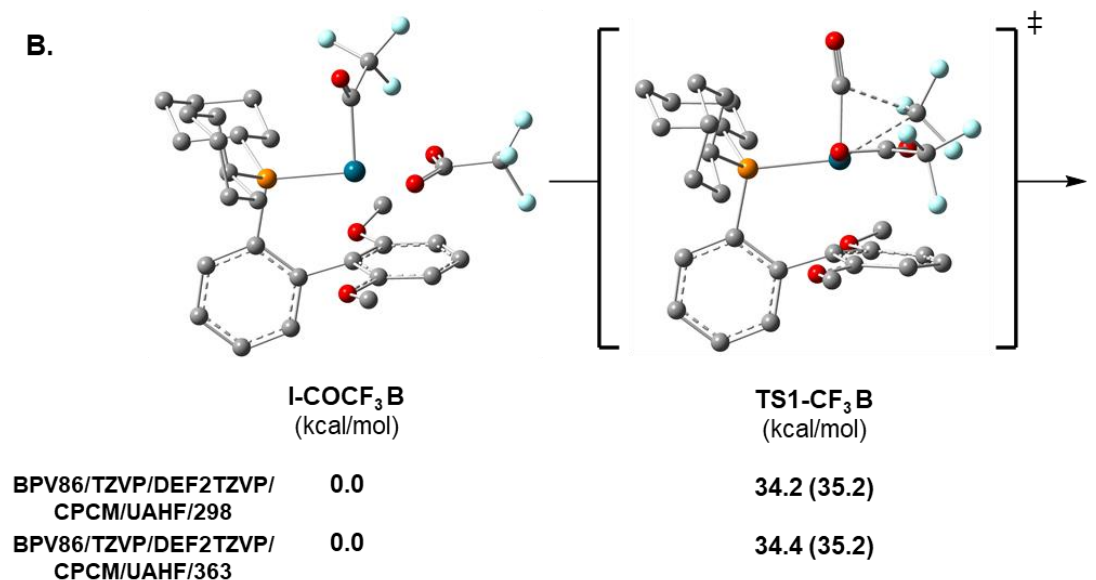

34.2 (35.2)

$34.4(35.2)$

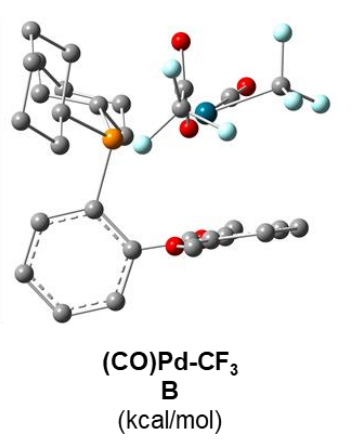

$8.5(5.3)$

$9.0(5.2)$

Figure S22. The DFT-based optimized geometries of the optimized $\mathbf{C F}_{3}$-containing reactant complexes $\left(\mathbf{I}-\mathbf{C O C F}_{3} \mathbf{A}\right.$ and $\mathbf{B}$ ), transition states $\left(\mathbf{T S} \mathbf{1}-\mathbf{C F}_{3} \mathbf{A}\right.$ and $\left.\mathbf{B}\right)$, and intermediates $(\mathbf{C O}) \mathbf{P d}-\mathbf{C F}_{3} \mathbf{A}$ and $\mathbf{B}$ are shown above with energy values. The activation free energies for the $\mathrm{C}_{(\mathrm{CO})}-\mathrm{CF}_{3}$ bond cleavage, and subsequent CO-reorientation process are presented. The evaluation of the effect of functional, basis set and solvation models on the energetic trends at both $298 \mathrm{~K}$ and $363 \mathrm{~K}$ are shown. Enthalpic contributions to the free energy values shown in parentheses.

The energetics shown above in Figure S22 are reflective of the experimental findings, in which elevated temperatures are required for the decarbonylation of I-COCF 3 to form II-CF 3 . Going forward, the energetic values corresponding to I$\mathbf{C O C F}_{3} \mathbf{A}, \mathbf{T S} 1-\mathbf{C F}_{3} \mathbf{A}$, and (CO)Pd-CF 3 were selected for further discussion. 
A.
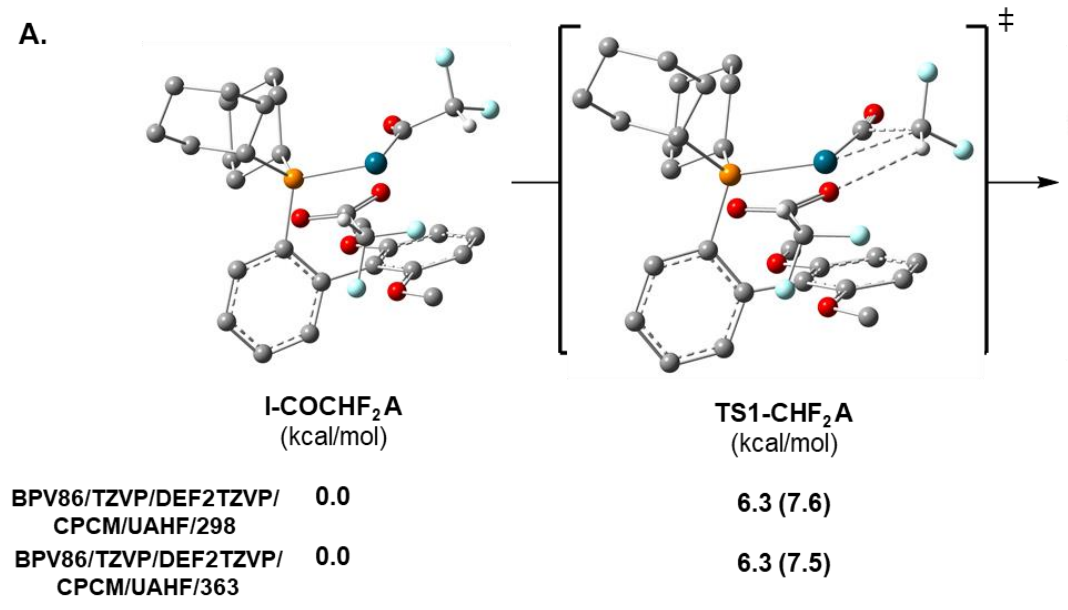

cal/mol)

$6.3(7.6)$

$6.3(7.5)$

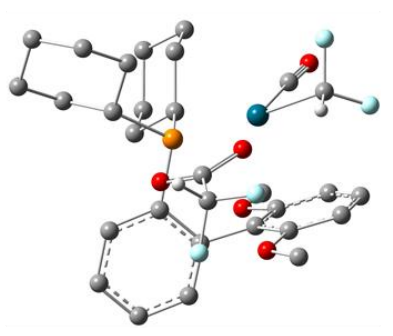
$\underset{\mathrm{A}}{\text { (CO)Pd}-\mathrm{CHF}_{2}}$
$(\mathrm{kcal} / \mathrm{mol})$

$-8.5(-7.2)$

$-8.6(-7.1)$

B.
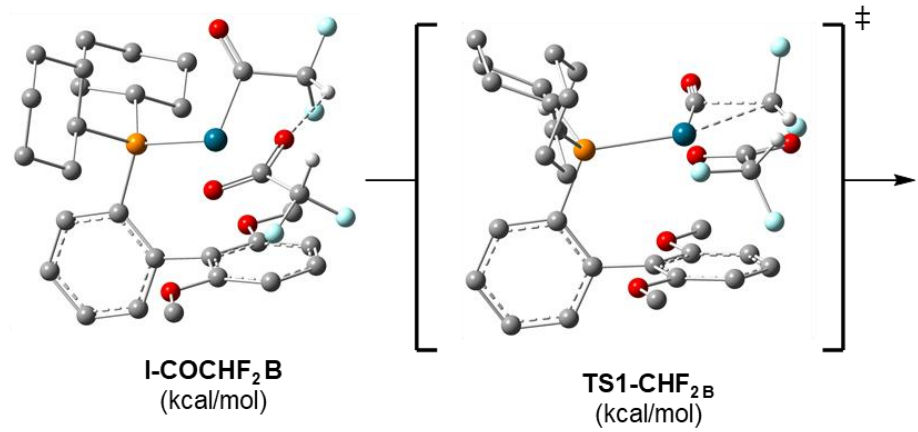

$9.3(14.5)$

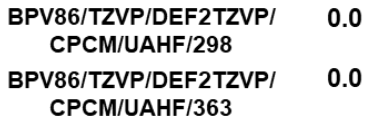

13.4 (17.5)

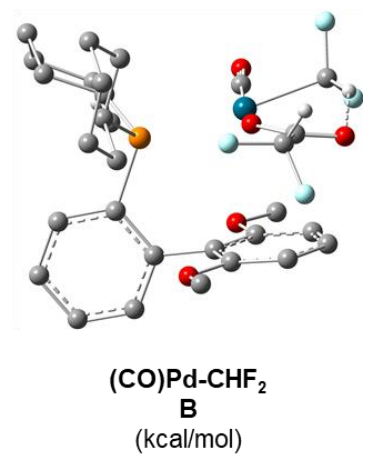

$1.3(5.2)$

$5.4(8.4)$

Figure S23. The DFT-based optimized geometries of the $\mathbf{C H F}_{2}$-containing reactant complexes (I-COCHF $\mathbf{A}$ and $\mathbf{B}$ ), transition states ( $\mathbf{T S} \mathbf{1}-\mathbf{C H F}_{2} \mathbf{A}$ and $\mathbf{B}$ ), and intermediates $(\mathbf{C O}) \mathbf{P d}-\mathbf{C H F}_{2} \mathbf{A}$ and $\mathbf{B}$ are shown above with energy values. The activation free energies for the $\mathrm{C}_{(\mathrm{CO})}-\mathrm{CF}_{3}$ bond cleavage, and subsequent $\mathrm{CO}$-reorientation process are presented. The evaluation of the effect of functional, basis set and solvation models on the energetic trends at both $298 \mathrm{~K}$ and 363 $\mathrm{K}$ are shown. Enthalpic contributions to the free energy values shown are in parentheses.

The energetics shown above in Figure S23 are reflective of the experimental findings, in which the decarbonylation of $\mathrm{I}_{-} \mathrm{COCHF}_{2}$ to form II-CHF 2 proceeds at room temperature. Going forward, the energetic values corresponding to I$\mathbf{C O C H F}_{2} \mathbf{A}, \mathbf{T S} 1-\mathrm{CHF}_{2} \mathbf{A}$, and (CO)Pd-CHF 2 were selected for further discussion. 
A

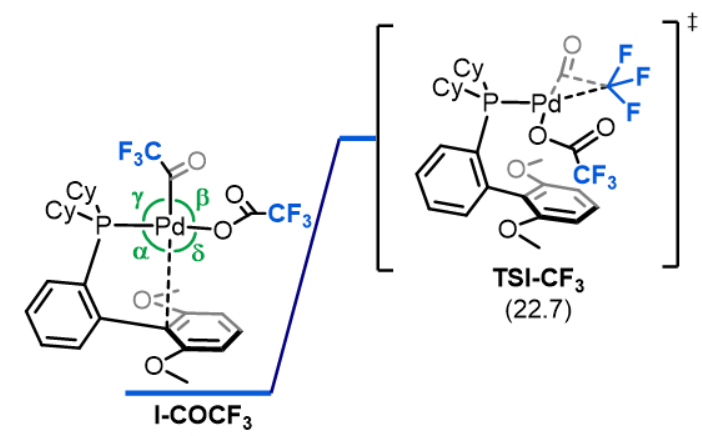

(0.0)

$\mathrm{I}-\mathrm{COCF}_{3} \mathrm{~A}$

\begin{tabular}{|c|c|}
\hline $\begin{array}{r}\mathrm{Pd} \ldots \mathrm{C}_{\mathrm{Ar}}= \\
\mathrm{Pd} \ldots \mathrm{C}_{\mathrm{OCH}_{3}}(\text { back })= \\
\mathrm{Pd} \ldots \mathrm{C}_{\mathrm{OCH}_{3}}(\text { front })= \\
\mathrm{Pd} \ldots \mathrm{OCH}_{3}(\text { back })= \\
\mathrm{Pd} . . \mathrm{OCH}_{3}(\text { front })=\end{array}$ & $\begin{array}{l}3.16 \AA \\
3.40 \AA \\
3.26 \AA \\
4.05 \AA \\
3.82 \AA\end{array}$ \\
\hline $\begin{array}{r}\mathrm{CF}_{3} \ldots \mathrm{Pd}= \\
\mathrm{CF}_{3} \ldots \mathrm{C}=\mathrm{O}= \\
\mathrm{Pd} \ldots \mathrm{C}=\mathrm{O}=\end{array}$ & $\begin{array}{l}2.94 \AA \\
1.56 \AA \\
1.94 \AA\end{array}$ \\
\hline$\alpha=$ & $\begin{array}{r}70.6^{\circ} \\
97.5^{\circ} \\
91.4^{\circ} \\
114.2^{\circ}\end{array}$ \\
\hline
\end{tabular}

TS1- $\mathrm{CF}_{3} \mathrm{~A}$

$3.31 \AA$
$3.73 \AA$
$3.18 \AA$
$4.47 \AA$
$3.57 \AA$
$2.50 \AA$
$2.03 \AA$
$1.85 \AA$
$67.3^{\circ}$
$123.6^{\circ}$
$104.0^{\circ}$
$95.3^{\circ}$

$95.3^{\circ}$
$\Delta\left(\mathrm{TS} 1-\mathrm{CF}_{3} \mathrm{~A}-\mathrm{I}-\mathrm{COCF}_{3}\right)$

$+0.15 \AA$

$+0.33 \AA$

$-0.08 \AA$

$+0.42 \AA$

$-0.25 \AA$

$-0.44 \AA$

$+0.47 \AA$

$-0.09 \AA$

$-3.3^{\circ}$

$+26.1^{\circ}$

$+12.6^{\circ}$

$-18.9^{\circ}$

B

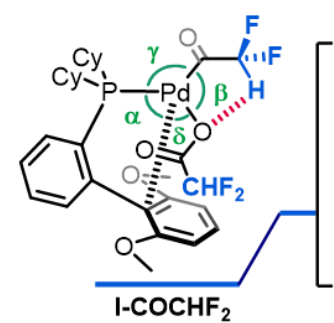

(0.0)

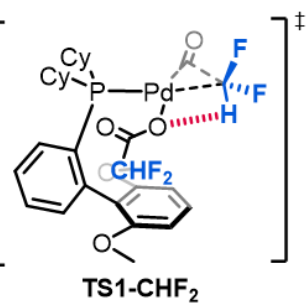

(6.3)

$\mathrm{I}-\mathrm{COCHF}_{2} \mathrm{~A}$

TS1-CHF ${ }_{2} \mathrm{~A} \quad \Delta\left(\mathrm{TS}_{1}-\mathrm{CHF}_{2} \mathrm{~A}-\mathrm{I}-\mathrm{COCHF}{ }_{2}\right)$

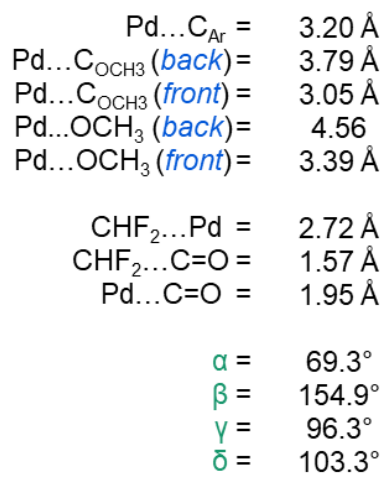

$3.29 \AA$

$3.85 \AA$

$3.10 \AA$

$4.67 \AA$

$3.45 \AA$

$2.40 \AA$

$1.91 \AA$

$1.86 \AA$

$66.3^{\circ}$

$148.8^{\circ}$

$105.5^{\circ}$

$101.1^{\circ}$
$+0.09 \AA$

$+0.06 \AA$

$+0.05 \AA$

$+0.12 \AA$

$+0.06 \AA$

$-0.32 \AA$

$+0.34 \AA$

$-0.09 \AA$

$\alpha=-3.0^{\circ}$

$\beta=-6.1^{\circ}$

$\gamma=+9.2^{\circ}$

$\overline{0}=-2.2^{\circ}$

Figure S24. The calculated bond lengths, distances, and angles for intermediates (A) I-COCF 3 and transition state $\mathbf{T S} 1-\mathbf{C F}_{3}$ and $(\mathrm{B}) \mathbf{I}-\mathbf{C O C H F}_{2}$ and $\mathbf{T S}-\mathbf{C H F}_{2}$. Angles $\alpha, B, \gamma$, and $\delta$ are defined by the three atoms involved and are conserved in both structures (e.g., $B$ is defined as the angle between the two fluoroalkyl ligands with Pd as the vertex in both structures). 
The data above highlight specific bond lengths, distances, and angles which show that the optimized conformer of I$\mathbf{C O C H F}_{2}$ is greatly distorted away from the expected square planar geometry. Comparatively, the ground state geometry of $\mathrm{I}_{-} \mathrm{COCF}_{3}$ shows angles much closer to a typical Pd" square planar complex. Given that carbonyl deinsertion at $\mathrm{Pd}^{\prime \prime}$ is proposed to occur via three-coordinate $\mathrm{Pd}$ complexes ${ }^{15}$, we propose that the distortion of the coordination geometry at I-COCHF 2 contributes to a barrier-lowering effect to proceed through $\mathbf{T S} \mathbf{1}-\mathbf{C H F}_{2}$.

\section{B. Analysis of dispersive repulsive electrostatic interactions}

Differential electrostatic potential maps visualized electrostatic charge distribution differences between these complexes. For $\mathrm{CF}_{3}$-derived skeletons, the plotted electrostatic potential surfaces of the complexes show greater and closer proximity of the strongly negatively polarized groups in the $\mathrm{CF}_{3}$-substituted complexes in comparison to the analogous $-\mathrm{CHF}_{2}$ complexes. Specifically, these dispersive, repulsive electrostatic interactions are more pronounced for the transition states than for the reactants in $\mathrm{CF}_{3}$-derived complexes resulting in a higher activation barrier for 1,1de-insertion via $\mathbf{T S} \mathbf{-} \mathbf{C F}_{3}$.

A.

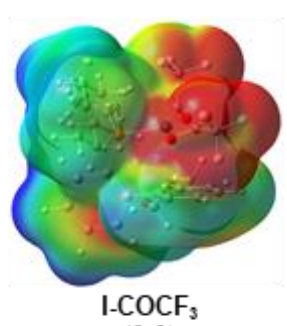

$(0.0)$

B.

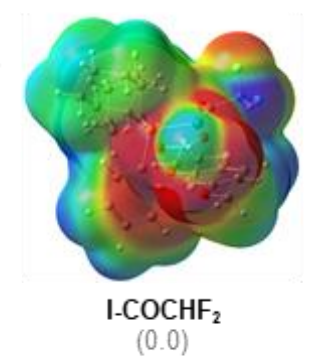

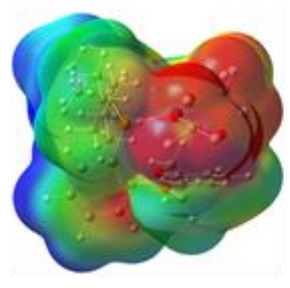

$\mathrm{TS}_{1}-\mathrm{CF}_{3}$

(22.7)

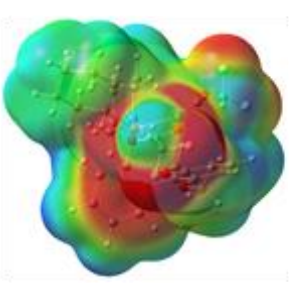

TS1-CHF (6.3)

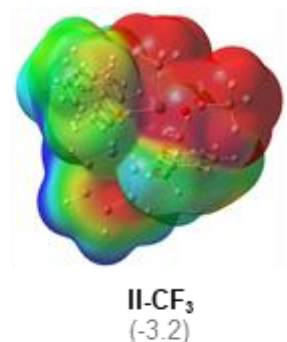

$(-3.2)$

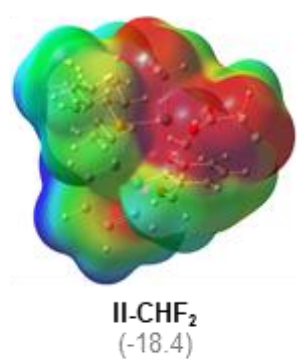

Figure S25. The electrostatic potential surfaces of the (A) trifluoromethyl and (B) difluoromethyl complexes, transition states and final decarbonylated products with surface views. Red regions are negative and blue regions are positive.

Our calculations show the existence of several stabilizing non-covalent interactions and weakly attractive bonding interactions in $\mathrm{CHF}_{2}$-derived complexes, such as London dispersion forces and weak attractive van der Waals interactions that stabilize $\mathbf{T S 1}-\mathbf{C H F}_{2}$ compared to $\mathbf{T S 1}-\mathbf{C F}_{3}$. Accordingly, second sphere components in these complexes, such as the cyclohexyl rings and methoxy groups of SPhos, synergistically benefit from their mutual interactions with $\mathrm{CHF}_{2}$. These non-covalent and donor-acceptor stabilizing interactions contribute to the distinct conformation of $\mathrm{CHF}_{2}$ derived complexes, producing a barrier-lowering effect for carbonyl de-insertion. In contrast, $\mathbf{T S}^{-\mathbf{C F}_{3}}$ lacks the stabilizing electrostatic interaction with the same degree and features fewer attractive interactions. 
A.

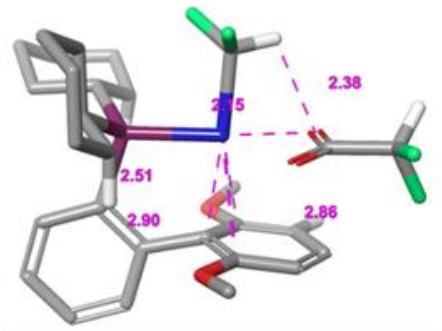

II- $\mathrm{CHF}_{2}$

$\Delta G(T H F)=-7.5$ to $-18.4 \mathrm{Kcal} / \mathrm{mol}$

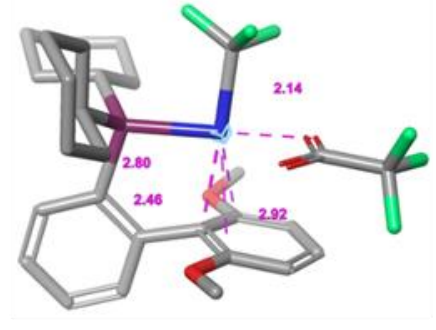

$\mathrm{II}-\mathrm{CF}_{3}$

$\Delta G(T H F)=-3.2$ to $3.4 \mathrm{Kcal} / \mathrm{mol}$

B.
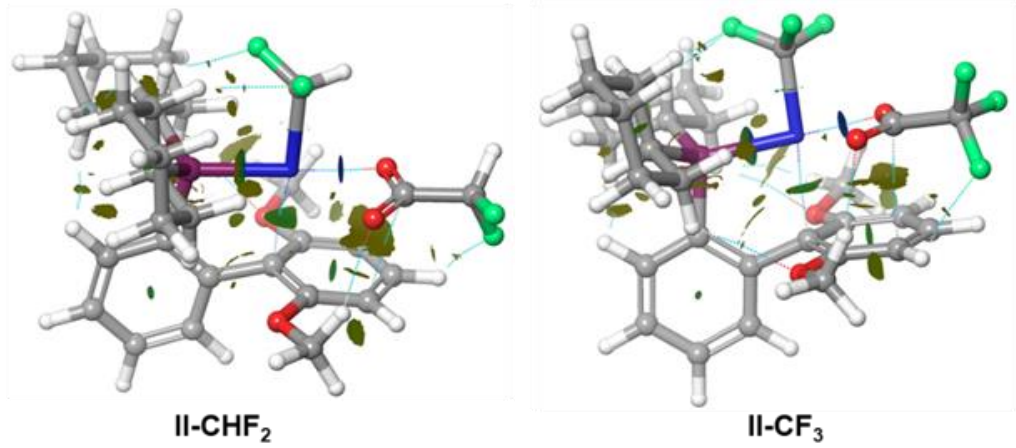

Figure S26. (A) The DFT-based optimized II-CHF 2 and II-CF 3 conformers with change in free energies shown relative to $\mathrm{I}-\mathrm{COCHF}_{2}$ and $\mathbf{I}-\mathrm{COCF}_{3}$, respectively. (B) the calculated $\mathrm{NCl}$ gradient iso-surfaces with $\mathrm{s}=0.3$ au representing the attractive non-covalent interactions, colored according to the values of $\operatorname{sign}\left(\lambda^{2}\right) \rho$ between -0.5 to $0.5 \mathrm{au}$. In this coloring system, green and yellow iso-surfaces are related to weakly attractive and weakly repulsive interactions respectively; blue boundaries show attractive interactions; and red boundaries show repulsive interactions. Highly favorable interactions are shown as disks of purple color.

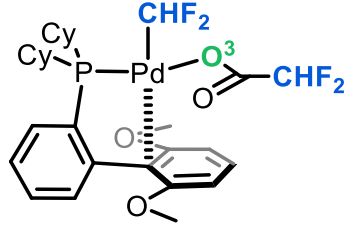

$\mathrm{II}-\mathrm{CHF}_{2}$

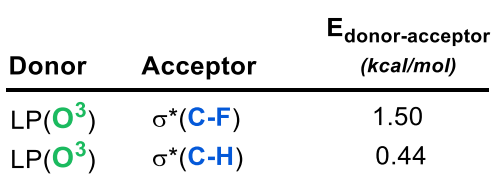

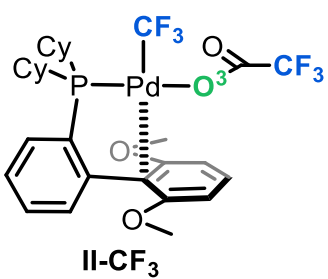

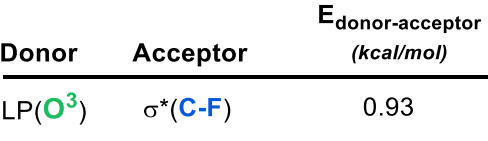

Figure S27. The sum of predicted NBO derived donor-acceptor orbital interactions for (A) II-CHF 2 and (B) II-CF . The

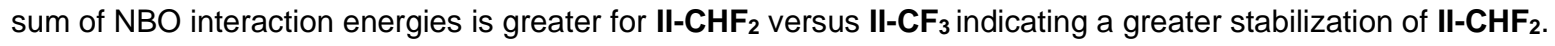

The combined computational data above reveal that a series attractive interactions (orbital interaction, attractive electrostatic interactions, and non-covalent interactions) were highly influential to the observed decarbonylative reactivity as shown by our combined application of quantum mechanical techniques such as natural bond orbital (NBO) analysis, non-covalent interactions $(\mathrm{NCl})$ index analysis, and the molecular electrostatic potential (MEP) surface maps. 
According to our study, the structural, energetic, and electronic parameters within the optimized geometries of $\mathrm{CF}_{3}$ and $\mathrm{CHF}_{2}$-bearing complexes highlighted the presence of several attractive interactions comprised of 1) the orbital interaction that accounts for charge transfer (i.e., donor-acceptor interactions); 2) a series of weakly attractive noncovalent bonding interactions such as induced dipole-induced dipole (London dispersion forces) interactions; and 3) attractive electrostatic interaction that accounts for the electrostatic charge distribution to recognize the reactive sites with positive and negative electron density.

\section{References}

1. (a) Maleckis, A.; Sanford, M. S. Catalytic cycle for palladium-catalyzed decarbonylative trifluoromethylation using trilfuoroacetic esters as the $\mathrm{CF}_{3}$ source. Organometallics 2014, 33, 2653-2660; (b) See, Y. Y., MoralesColon, M. T.; Bland, D. C.; Sanford, M. S. Development of SNAr nucleophilic fluorination: a fruitful academiaindustry collaboration. Acc. Chem. Res. 2020, 53, 2372-2383.

2. Kaspi, A. W.; Yahav-Levi, A.; Goldberg, I.; Vigalok, A. Xenon difluoride induced aryl iodide reductive elimination: a simple access to difluoropalladium(II) complexes. Inorg. Chem. 2008, 47, 1, 5-7.

3. Fang, H.; Kaur, G.; Yan, J.; Wang, B. An efficient synthesis of sterically hindered arylboronic acids. Tet. Lett. 2005, 46, 1671-1674.

4. Matthew, C. S.; Glasspoosle, B. W.; Eisenberger, P.; Crudden, C. M. Synthesis of enantiomerically enriched triarylmethanes by enantiospecific Suzuki-Miyaura cross coupling reactions. J. Am. Chem. Soc. 2014, 136, 5828-5831.

5. Wrackmeyer, B. Carbon-13 NMR spectroscopy of boron compounds. Progress in NMR spectroscopy 1978, 12, 227-259.

6. Malapit, C. A.; Bour, J. R.; Laursen, S. R.; Sanford, M. S. Mechanism and scope of-catalyzed decarbonylative borylation of carboxylic acid fluorides. J. Am. Chem. Soc. 2019, 141, 17322-17330.

7. Ferguson, D. M.; Bour, J. R.; Canty, A. J. Kampf, J. W. Sanford, M. S. Stoichiometric and catalytic arylperfluoroalkyl coupling at tri-tert-butylphosphine palladium(II) complexes. J. Am. Chem. Soc. 2017, 139, 11662-11665.

8. Lishchynskyi, A.; Grushin, V. V. Cupration of $\mathrm{C}_{2} \mathrm{~F}_{5} \mathrm{H}$ : Isolation, structure, and synthetic applications of $\left[\mathrm{K}(\mathrm{DMF})_{2}\right]\left[(t-\mathrm{BuO}) \mathrm{Cu}\left(\mathrm{C}_{2} \mathrm{~F}_{5}\right)\right]$. Highly efficient pentafluoroethylation of unactivated aryl bromides. J. Am. Chem. Soc. 2013, 135, 12584.

9. a) Schrödinger Release 2019-2: MacroModel, Schrödinger, LLC, New York, NY, 2019. b) Schrödinger Release 2019-2: Maestro, Schrödinger, LLC, New York, NY, 2019.

10. Frisch, M. J.; Trucks, G. W.; Schlegel, H. B.; Scuseria, G. E.; Robb, M. A.; Cheeseman, J. R.; Scalmani, G.; Barone, V.; Mennucci, B.; Petersson, G. A.; Nakatsuji, H.; Caricato, M.; Li, X.; Hratchian, H. P.; Izmaylov, A. F.; Bloino, J.; Zhang, G.; Sonnenberg, J. L.; Hada, M.; Ehara, M.; Toyota, K.; Fukuda, R.; Hasegawa, J.; Ishida, M.; Nakajima, T.; Honda, Y.; Kitao, O.; Nakai, H.; Vreven, T.; Montgomery, J. A.; Peralta, Jr., J. E.; Ogliaro, F.; Bearpark, M.; Heyd, J. J.; Brothers, E.; Kudin, K. N.; Staroverov, V. N.; Kobayashi, R.; Normand, J.; Raghavachari, K.; Rendell, A.; Burant, J. C.; Iyengar, S. S.; Tomasi, J.; Cossi, M.; Rega, N.; Millam, J. M.; Klene, M.; Knox, J. E.; Cross, J. B.; Bakken, V.; Adamo, C.; Jaramillo, J.; Gomperts, R.; Stratmann, R. E.; Yazyev, O.; Austin, A. J.; Cammi, A. R.; Pomelli, C.; Ochterski, J. W.; Martin, R. L.; Morokuma, K.; Zakrzewski, V. G.; Voth, G. A.; Salvador, P.; Dannenberg, J. J.; Dapprich, S.; Daniels, A. D.; Farkas, Ö.; Foresman, J. B.; Ortiz, J. V.; Cioslowski, J.; Fox, D. J. Gaussian 09, Revision C.02; Gaussian, Inc.: Wallingford, CT, 2009. 
11. a) Roy, L. E.; Hay, P. J.; Martin, R. L. Revised Basis Sets for the LANL Effective Core Potentials. J. Chem. Theory Comput. 2008, 4, 1029-1031. b) Y. Zhao, D. G. Truhlar. Density Functionals with Broad Applicability in Chemistry. Acc. Chem. Res. 2008, 41, 157-167. c) S. Huzinaga, Gaussian Basis Sets for Molecular Calculations, Elsevier Science Pub. Co., Amsterdam, 1984. 15 P. J. Hay and W. R. Wadt, J. Chem. Phys., 1985, 82, 299-310. d) P. J. Hay and W. R. Wadt, Ab initio effective core potentials for molecular calculations. Potentials for the transition metal atoms Sc to Hg. J. Chem. Phys. 1985, 82, 270-283.

12. (a) Gonzalez, C.; Schlegel, H. B. An improved algorithm for reaction path following. J. Chem. Phys., 1989, 90, 2154-2161; (b) Gonzelez, C.; Schlegel, H. B. Reaction Path Following in Mass-Weighted Internal Coordinates. J. Phys. Chem., 1990, 94, 5523-5527.

13. (a) Barone, V.; Cossi, M. Quantum Calculation of Molecular Energies and Energy Gradients in Solution by a Conductor Solvent Model. J. Phys. Chem. A, 1998, 102, 1995-2001; (b) Cossi, M.; Rega, N.; Scalmani, G.; Barone, V. J. Energies, structures, and electronic properties of molecules in solution with the C-PCM solvation model. Comput. Chem., 2003, 24, 669-681.

14. (a) Reed, A. E.; Weinstock, R. B.; Weinhold, F. Natural population analysis. J. Chem. Phys., 1985, 83, 735746; (b) Reed, A. E.; Weinhold, F Natural localized molecular orbitals. J. Chem. Phys., 1985, 83, 1736-1740; (c) Reed, A. E.; Curtiss, L. A.; Weinhold, F. Intermolecular interactions from a natural bond orbital, donoracceptor viewpoint. Chem. Rev., 1988, 88, 899-926.

15. Ortuno, M. A.; Dereli, B.; Cramer, C. J. Mechanism of Pd-catalyzed decarbonylation of biomass derived hydrocinnamic acid to styrene following activation as an anhydride. Inorg. Chem. 2016, 55, 4124-4131.

\section{X-Ray Crystallography Data for II-CHF}

\section{Structure determination of II-CHF 2}

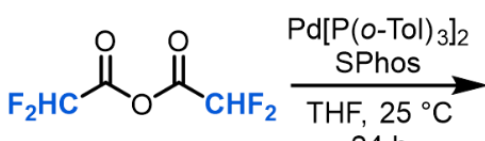

$24 \mathrm{~h}$
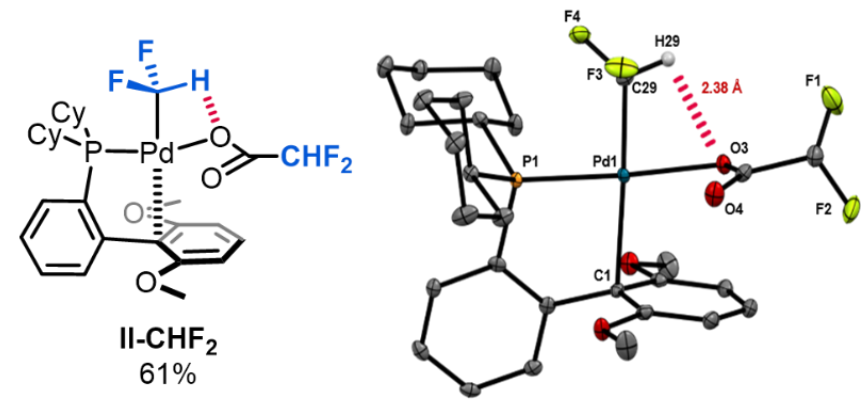

Yellow blocks of II-CHF 2 were grown via vapor diffusion of pentane/diethyl ether solution into tetrahydrofuran solution of the compound at $22^{\circ} \mathrm{C}$. A crystal of dimensions $0.22 \times 0.20 \times 0.16 \mathrm{~mm}$ was mounted on a Rigaku AFC10K Saturn 944+ CCD-based X-ray diffractometer equipped with a low temperature device and Micromax-007HF Cu-target microfocus rotating anode $(I=1.54187 \mathrm{~A})$ operated at $1.2 \mathrm{~kW}$ power $(40 \mathrm{kV}, 30 \mathrm{~mA})$. The X-ray intensities were measured at $85(1) \mathrm{K}$ with the detector placed at a distance $42.00 \mathrm{~mm}$ from the crystal. A total of 2028 images were collected with an oscillation width of $1.0^{\circ} \mathrm{in} \mathrm{w}$. The exposure times were $1 \mathrm{sec}$. for the low angle images, $3 \mathrm{sec}$. for high angle. Rigaku $d^{*}$ trek images were exported to CrysAlisPro for processing and corrected for absorption. The integration of the data yielded a total of 42225 reflections to a maximum $2 q$ value of $138.80^{\circ}$ of which 5201 were independent and 5166 were greater than $2 \mathrm{~s}(\mathrm{I})$. The final cell constants (Table S4) were based on the xyz centroids of 29274 reflections above $10 \mathrm{~s}(\mathrm{I})$. Analysis of the data showed negligible decay during data collection. The structure was solved and refined with 
the Bruker SHELXTL (version 2018/3) software package, using the space group P2(1)/c with Z = 4 for the formula C29H37O4F4PPd. All non-hydrogen atoms were refined anisotropically with the hydrogen atoms placed in idealized positions. The difluoroacetato group is rotationally disordered. Full matrix least-squares refinement based on F2 converged at $\mathrm{R} 1=0.0317$ and $w \mathrm{R} 2=0.0851$ [based on $\mathrm{I}>2$ sigma $(\mathrm{I})$ ], $\mathrm{R} 1=0.0319$ and $\mathrm{wR} 2=0.0853$ for all data. Additional details are presented in Table 4 and are given as Supporting Information in a CIF file. Acknowledgement is made for funding from NSF grant CHE-0840456 for X-ray instrumentation.

G.M. Sheldrick (2015) "Crystal structure refinement with SHELXL", Acta Cryst., C71, 3-8 (Open Access).

CrystalClear Expert 2.0 r16, Rigaku Americas and Rigaku Corporation (2014), Rigaku Americas, 9009, TX, USA 77381 5209, Rigaku Tokyo, 196-8666, Japan.

CrysAlisPro 1.171.38.41 (Rigaku Oxford Diffraction, 2015).

\begin{tabular}{|c|c|}
\hline Empirical formula & $\mathrm{C}_{29} \mathrm{H}_{37} \mathrm{~F}_{4} \mathrm{O}_{4} \mathrm{PPd}$ \\
\hline Formula weight & 662.95 \\
\hline Temperature & $85(2) \mathrm{K}$ \\
\hline Wavelength & $1.54184 \mathrm{~A}$ \\
\hline Crystal system & Monoclinic \\
\hline space group & $\mathrm{P} 2(1) / \mathrm{c}$ \\
\hline \multirow[t]{3}{*}{ Unit cell dimensions } & $a=9.68570(10) A \quad \alpha=90^{\circ}$ \\
\hline & $b=18.93400(10) A \quad B=91.4640(10)^{\circ}$ \\
\hline & $c=15.37910(10) A \quad Y=90^{\circ}$ \\
\hline Volume & $2819.44(4) A^{\wedge} 3$ \\
\hline $\mathbf{Z}$ & 4 \\
\hline Calculated density & $1.562 \mathrm{Mg} / \mathrm{m}^{\wedge} 3$ \\
\hline Absorption coefficient & $6.373 \mathrm{~mm}^{\wedge}-1$ \\
\hline$F(000)$ & 1360 \\
\hline Crystal size & $0.220 \times 0.200 \times 0.160 \mathrm{~mm}$ \\
\hline Theta range for data collection & 3.703 to $69.400 \mathrm{deg}$. \\
\hline Limiting indices & $-11<=\mathrm{h}<=11,-22<=\mathrm{k}<=22,-17<=\mathrm{k}<=18$ \\
\hline Reflections collected / unique & $42225 / 5201[R($ int $)=0.0734]$ \\
\hline Completeness to theta & $67.684(99.0 \%)$ \\
\hline Absorption correction & Semi-empirical from equivalents \\
\hline Max. and min. transmission & 1.00000 and 0.64949 \\
\hline Refinement method & Full-matrix least-squares on $\mathrm{F}^{2}$ \\
\hline Data / restraints / parameters & $5201 / 6 / 366$ \\
\hline Goodness-of-fit on F^2 & 1.054 \\
\hline Final $R$ indices $[\mid>2 \sigma(I)]$ & $\mathrm{R} 1=0.0317, \mathrm{wR} 2=0.0851$ \\
\hline $\mathbf{R}$ indices (all data) & $R 1=0.0319, w R 2=0.0853$ \\
\hline Largest diff. peak and hole & 0.799 and -0.744 e. $A^{-3}$ \\
\hline
\end{tabular}

Table S4. Addition details regarding crystals of II-CHF 2 . 


\section{XVII. ${ }^{1} \mathrm{H},{ }^{13} \mathrm{C},{ }^{19} \mathrm{~F}$ and ${ }^{31} \mathrm{P}$ NMR spectral data}

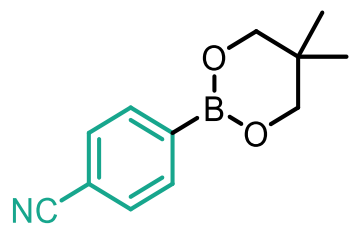

1b

${ }^{1} \mathrm{H}$ NMR
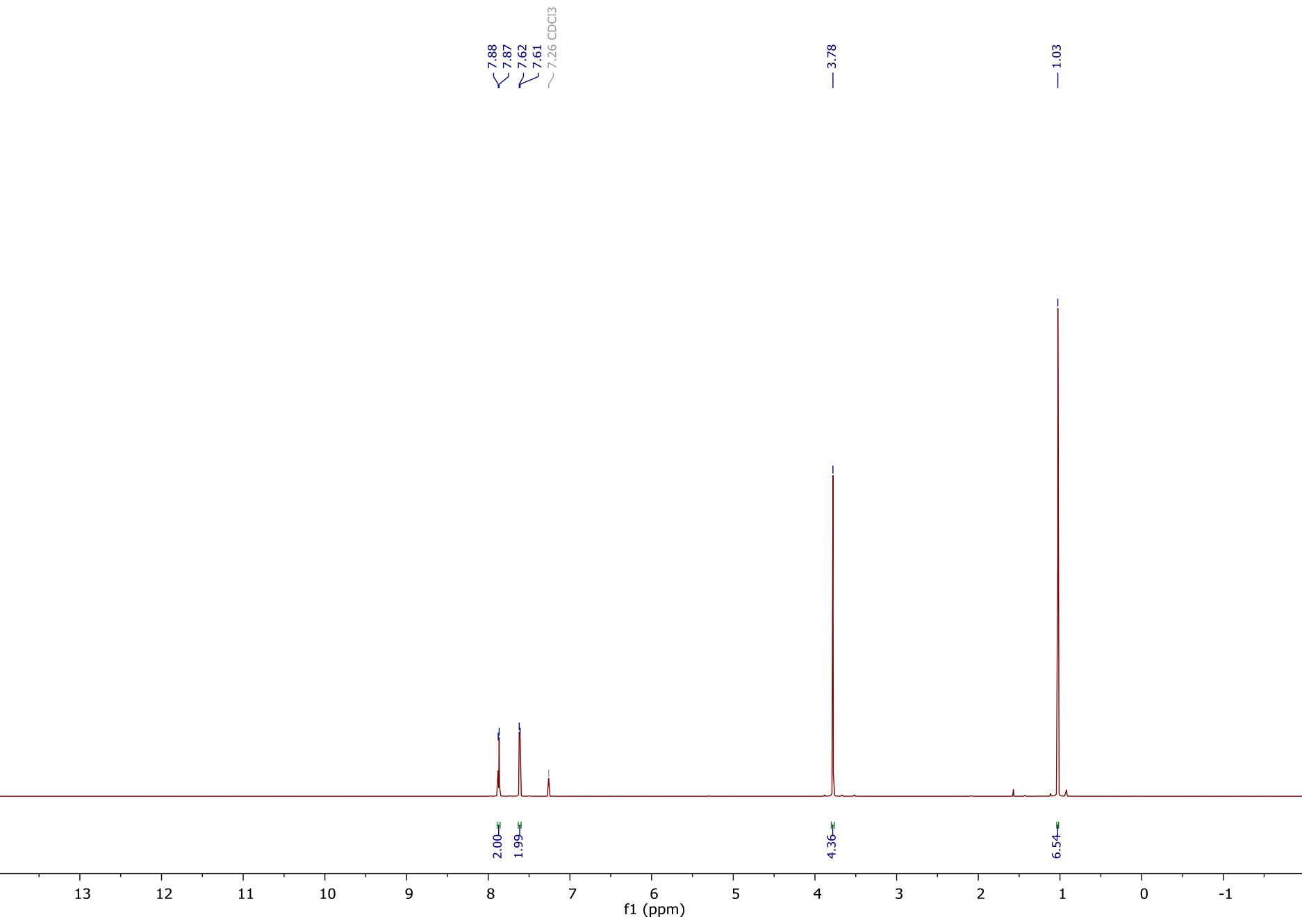


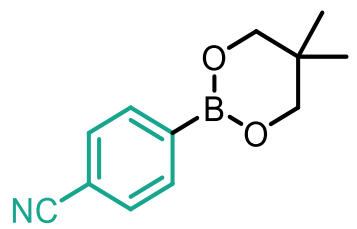

$1 b$

${ }^{13} \mathrm{C}$ NMR

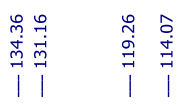

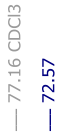

$\stackrel{\substack{0 \\ \text { in }}}{\stackrel{n}{N}}$

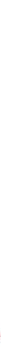

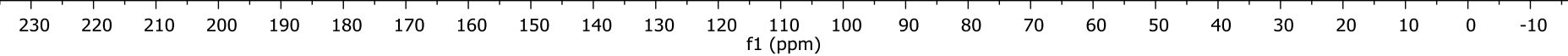


<smiles>CC1(C)OB(c2ccc(C#N)cc2)OC1(C)C</smiles>

$1 c$

${ }^{1} \mathrm{H}$ NMR

نَ 


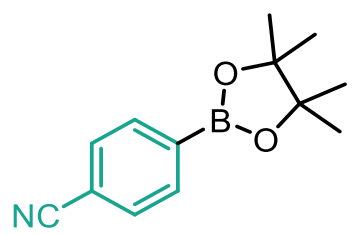

1c

${ }^{13} \mathrm{C}$ NMR

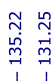

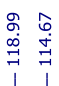

|

11

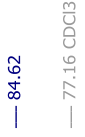

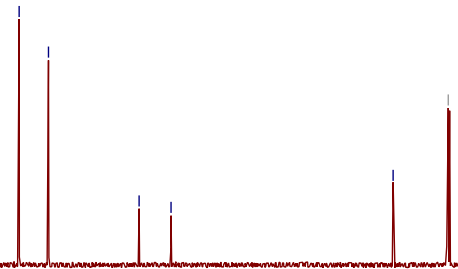

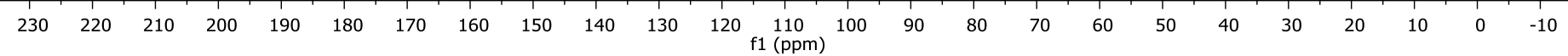


<smiles>Cc1cc(B2OCC(C)(C)CO2)ccc1C#N</smiles>

2b

${ }^{1} \mathrm{H}$ NMR

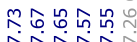

vil

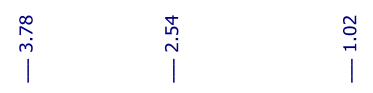


<smiles>Cc1cc(B2OCC(C)(C)CO2)ccc1C#N</smiles>

\section{$2 b$}

\section{${ }^{1} \mathrm{H}$ NMR}

|

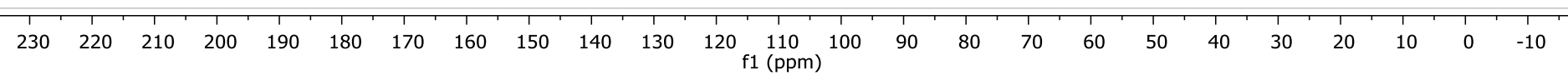


<smiles>CC1(C)COB(c2ccc(C(=O)c3ccccc3)cc2)OC1</smiles>

3b

${ }^{1} \mathrm{H}$ NMR

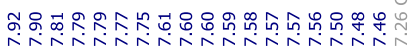

NiñN

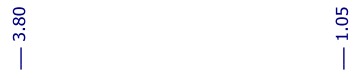

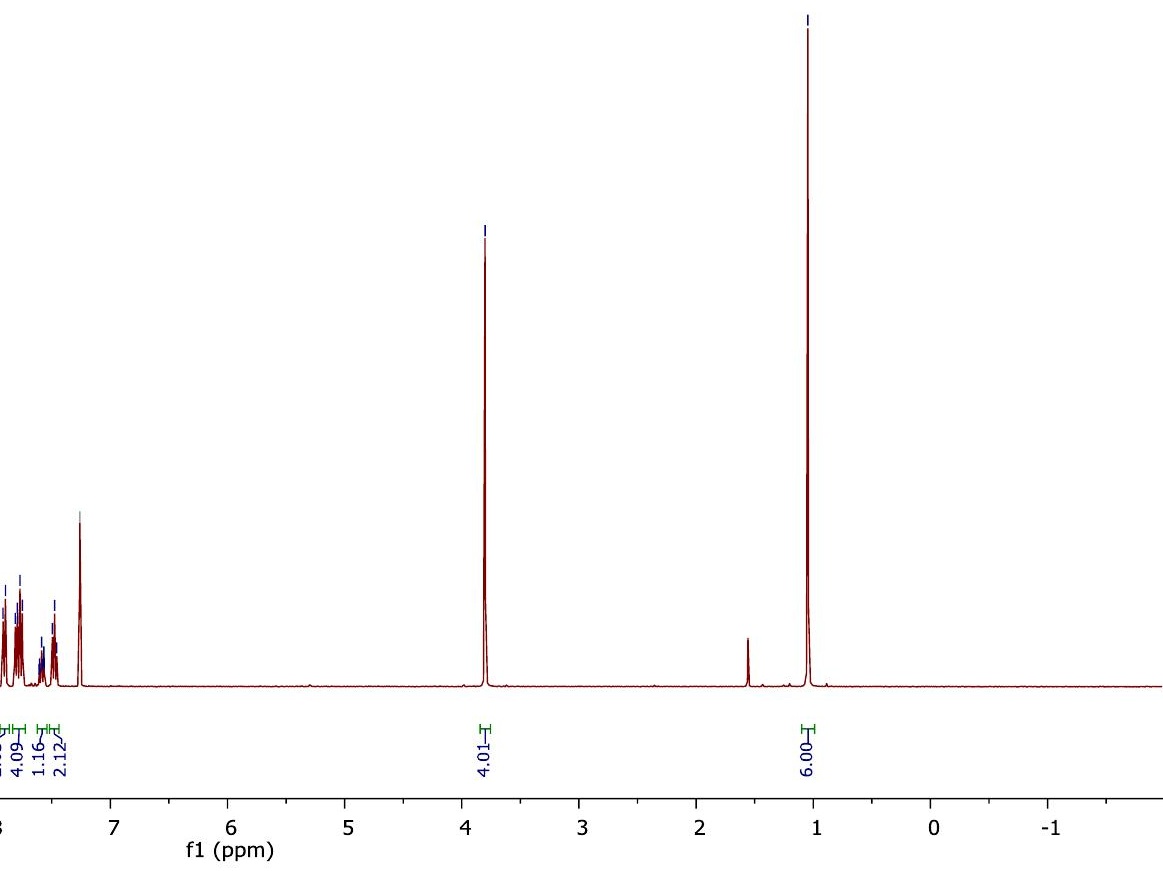


<smiles>CC1(C)COB(c2ccc(C(=O)c3ccccc3)cc2)OC1</smiles>

$3 b$

${ }^{1} \mathrm{H}$ NMR

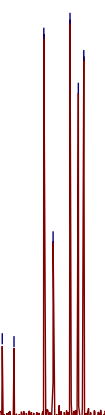

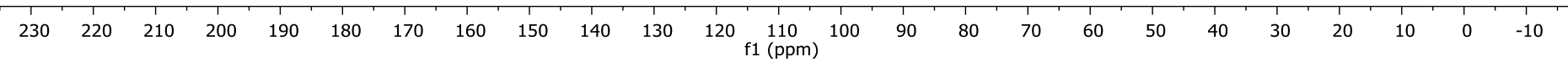




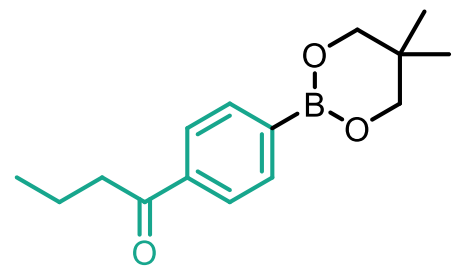

4b

${ }^{1} \mathrm{H}$ NMR
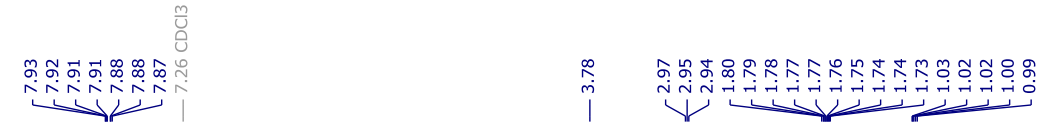

12

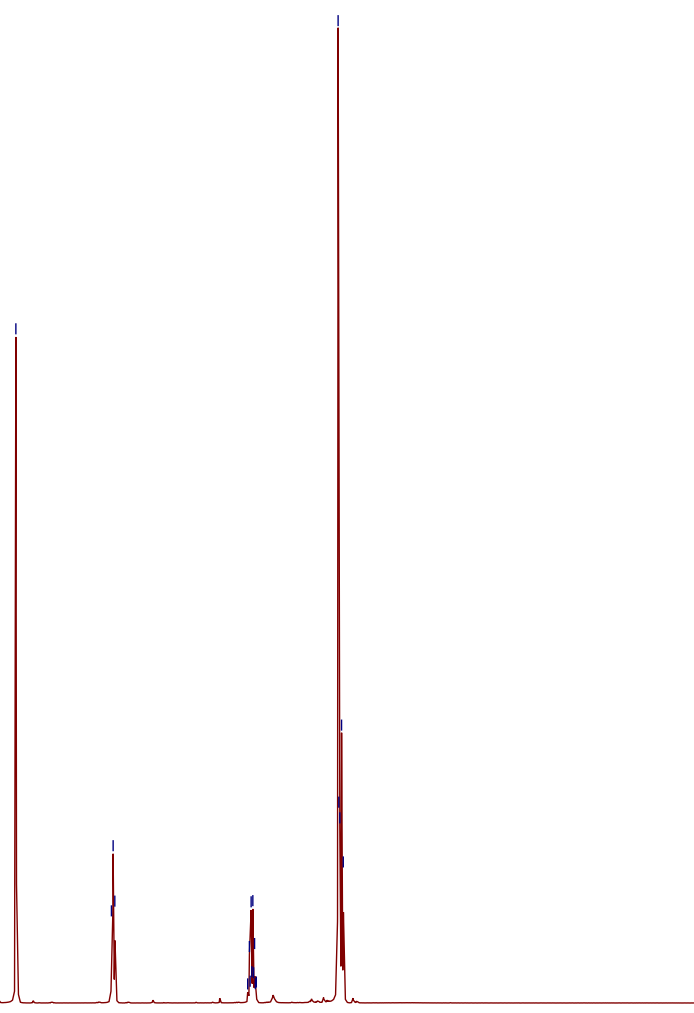

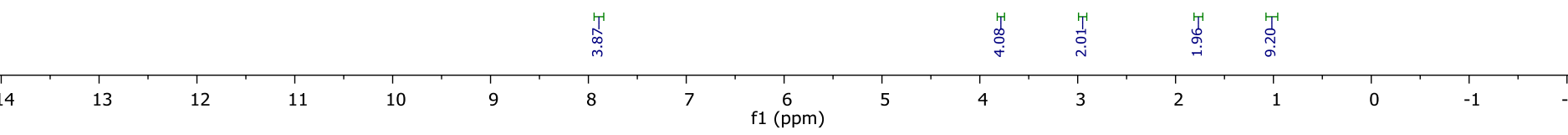


<smiles>CCCC(=O)c1ccc(B2OCC(C)(C)CO2)cc1</smiles>

4b

${ }^{1} \mathrm{H}$ NMR

$\stackrel{\circ}{\stackrel{1}{1}}$

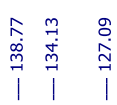

in

离

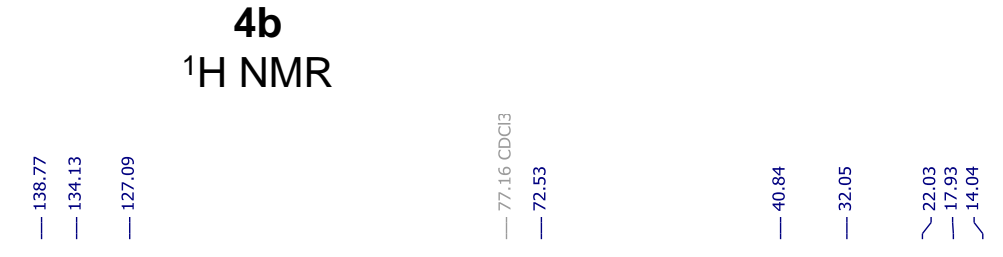

\begin{tabular}{|c|c|c|c|c|c|c|c|c|c|c|c|c|c|c|c|c|c|c|c|c|c|c|c|c|}
\hline 1 & 1 & 1 & 1 & 1 & 1 & 1 & 1 & 1 & 1 & 1 & 1 & 1 & 1 & 1 & 1 & 1 & 1 & 1 & 1 & 1 & 1 & 1 & 1 & \\
\hline 230 & 220 & 210 & 200 & 190 & 180 & 170 & 160 & 150 & 140 & 130 & 120 & $\begin{array}{c}110 \\
\mathrm{f} 1(\mathrm{ppm})\end{array}$ & 100 & 90 & 80 & 70 & 60 & 50 & 40 & 30 & 20 & 10 & 0 & -10 \\
\hline
\end{tabular}




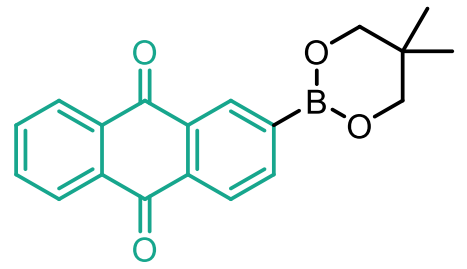

$5 b$

${ }^{1} \mathrm{H}$ NMR

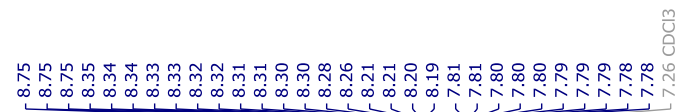

$\stackrel{\infty}{i}$

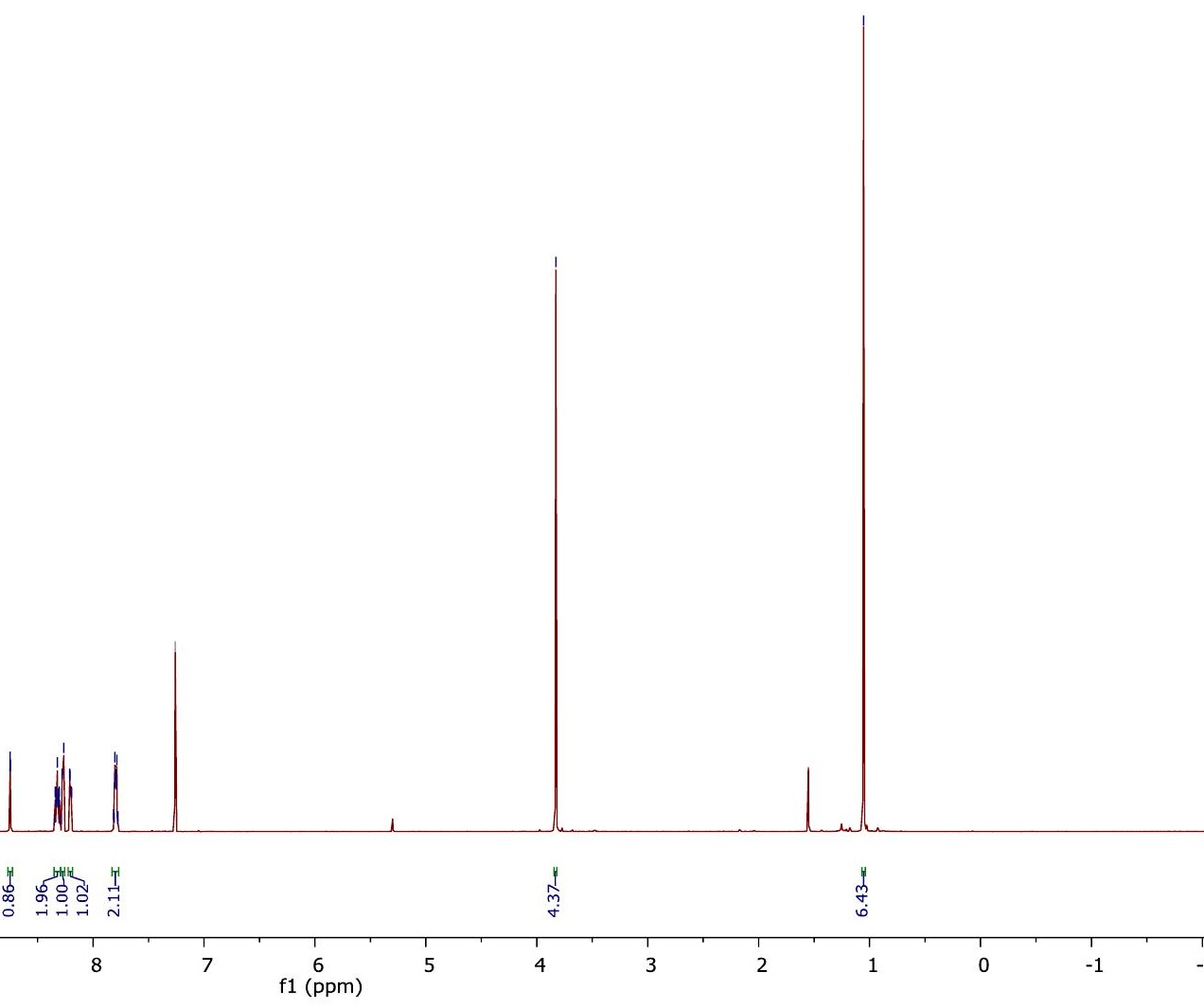


<smiles>CC1(C)COB(c2ccc3c(c2)C(=O)c2ccccc2C3=O)OC1</smiles>

$5 b$

${ }^{1} \mathrm{H}$ NMR

V)

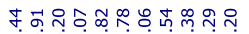

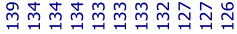

型

$\begin{array}{ll}1 & 1 \\ 0 & 0 \\ 0 \\ 0 \\ 0 \\ 0\end{array}$

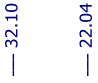

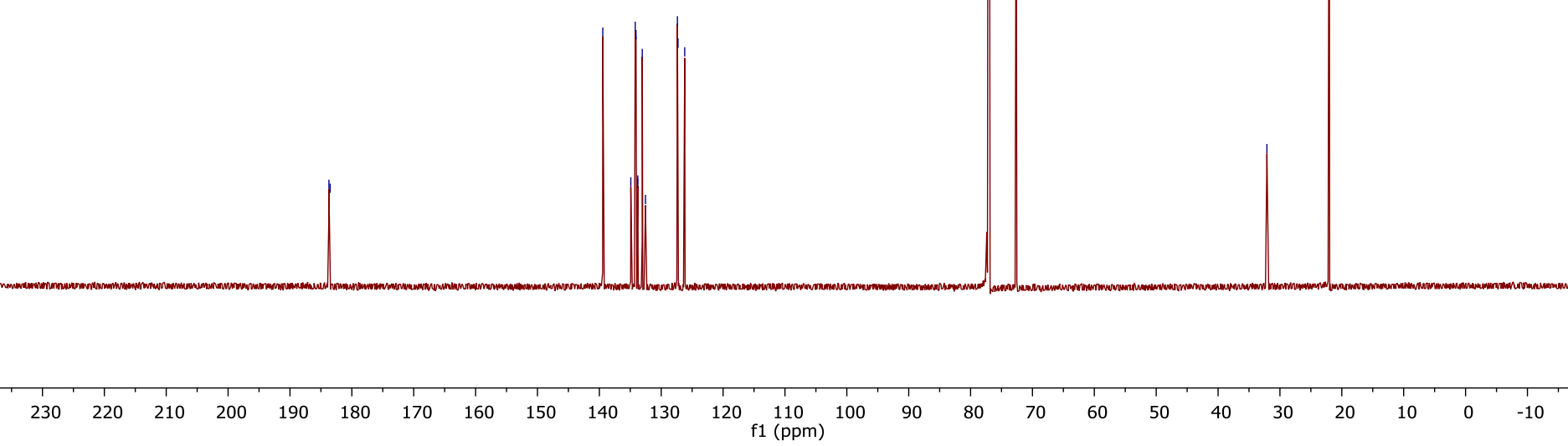


<smiles>CCOC(=O)c1ccc(B2OCC(C)(C)CO2)cc1</smiles>

$6 b$

${ }^{1} \mathrm{H}$ NMR

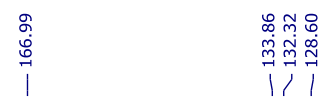

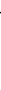


<smiles>COC(=O)c1ccc(B2OCC(C)(C)CO2)cc1</smiles>

7b

${ }^{1} \mathrm{H}$ NMR

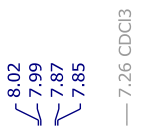

مَm

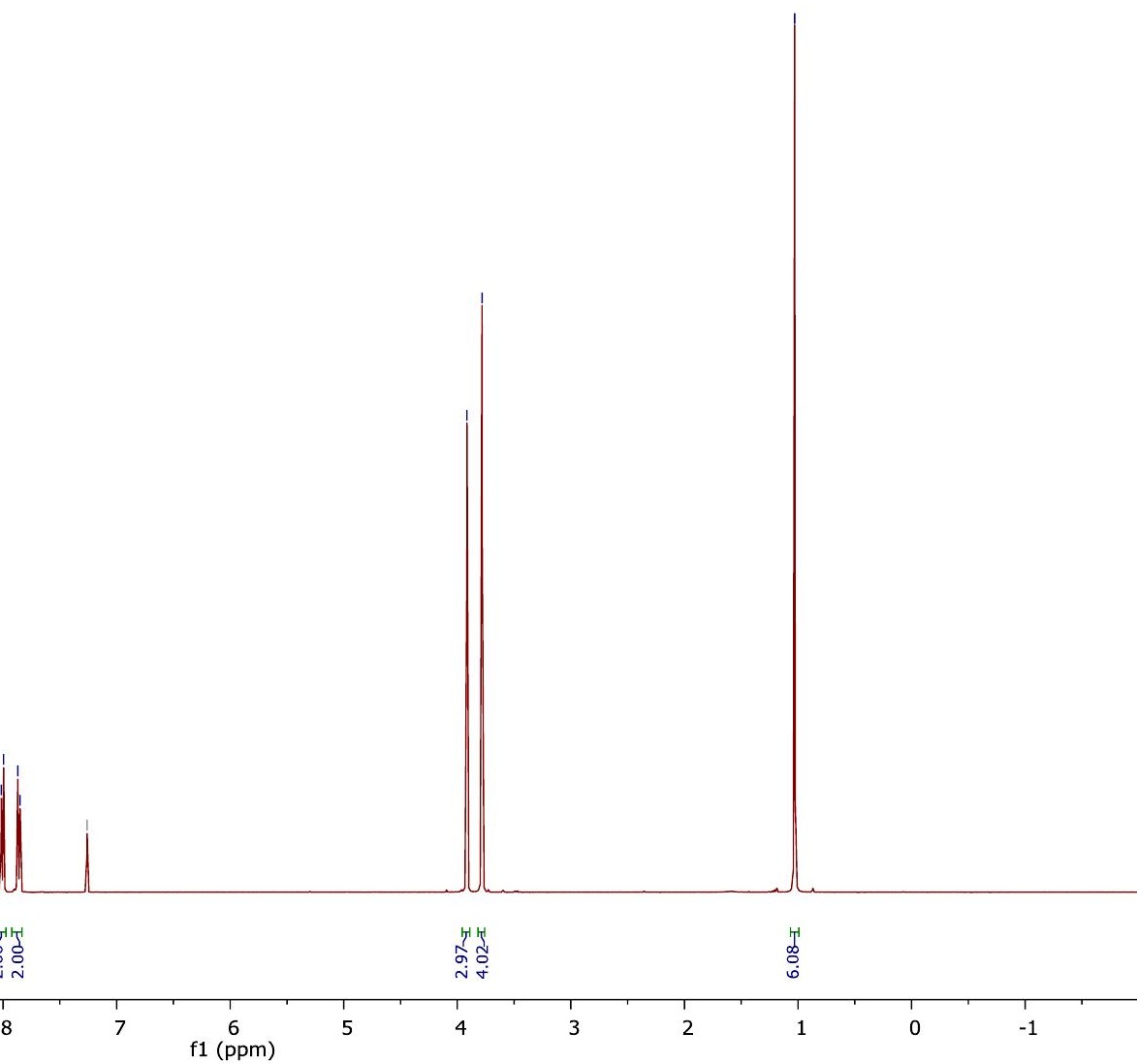


<smiles>COC(=O)c1ccc(B2OCC(C)(C)CO2)cc1</smiles>

$7 b$

${ }^{13} \mathrm{C}$ NMR

年

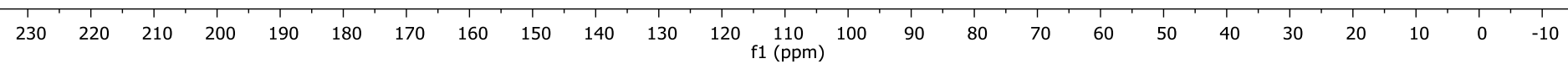


<smiles>CCOC(=O)c1cc(B2OCC(C)(C)CO2)cc(C(=O)OCC)c1</smiles>

$8 b$

${ }^{1} \mathrm{H}$ NMR

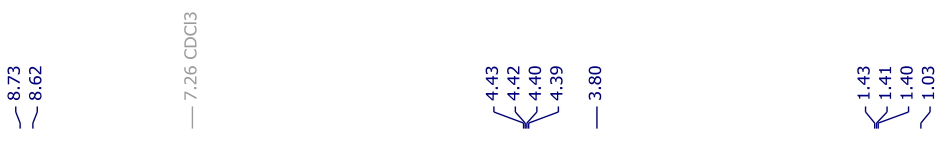


<smiles>CCOC(=O)c1cc(B2OCC(C)(C)CO2)cc(C(=O)OCC)c1</smiles>

\section{$8 b$}

${ }^{13} \mathrm{C}$ NMR

N

i

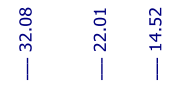
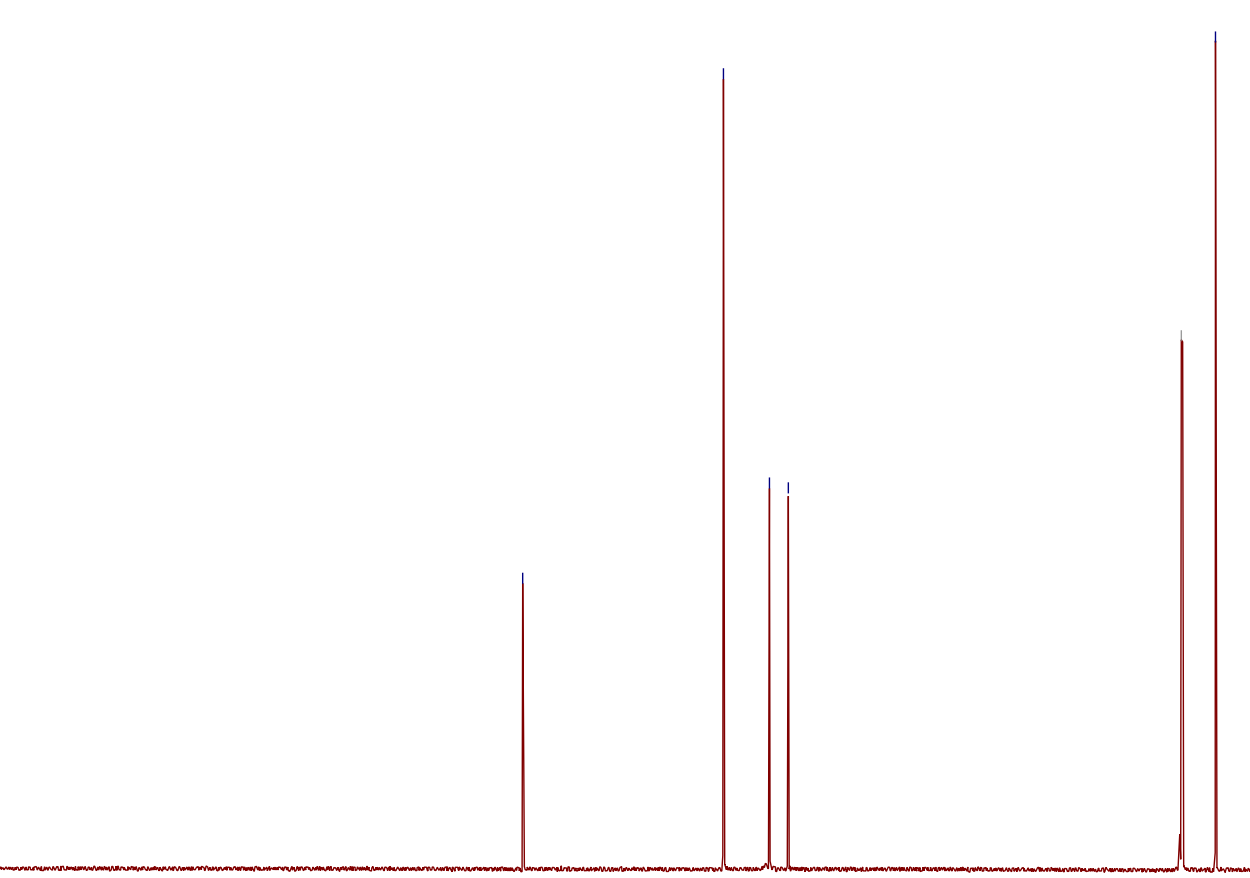

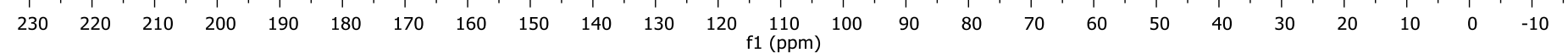



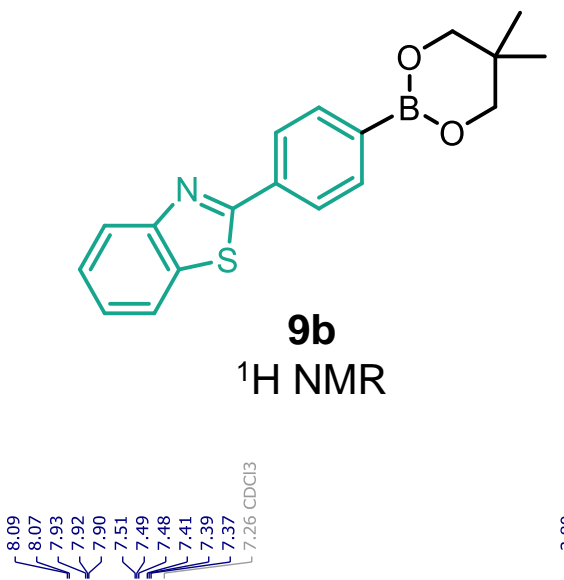

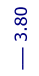
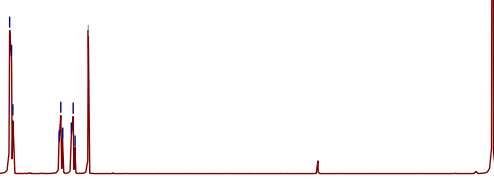

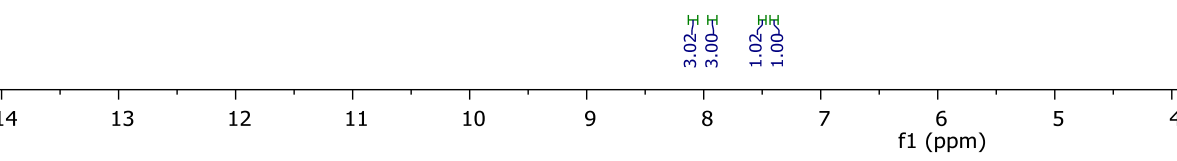




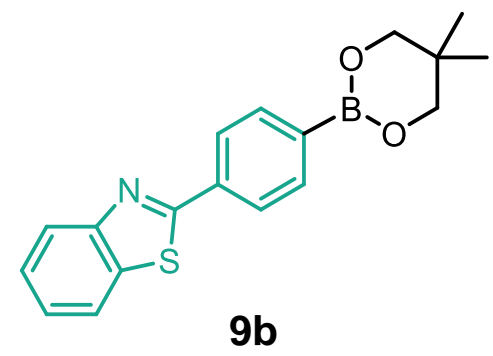

\section{${ }^{13} \mathrm{C}$ NMR}

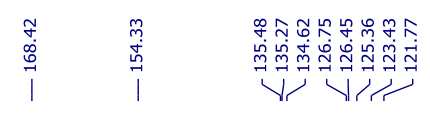

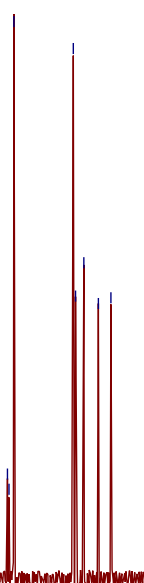

$\begin{array}{llllllllllllllllllllllllll}1 & 230 & 220 & 210 & 200 & 190 & 180 & 170 & 160 & 150 & 140 & 130 & 120 & \begin{array}{ll}110 \\ \mathrm{fppm})\end{array} & 100 & 90 & 80 & 70 & 60 & 50 & 40 & 30 & 20 & 10 & 0 & -10\end{array}$




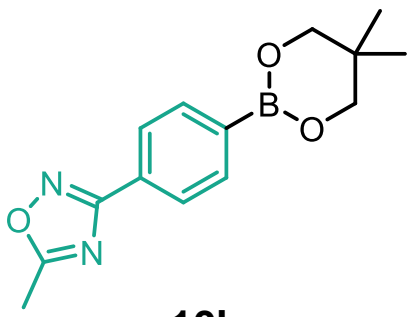

$10 b$

${ }^{1} \mathrm{H}$ NMR

権

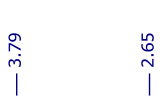

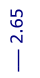
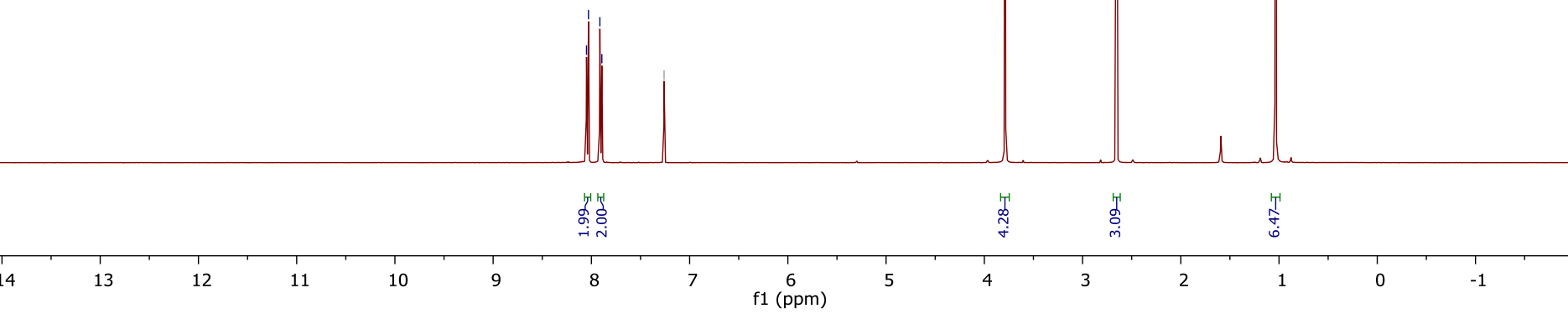


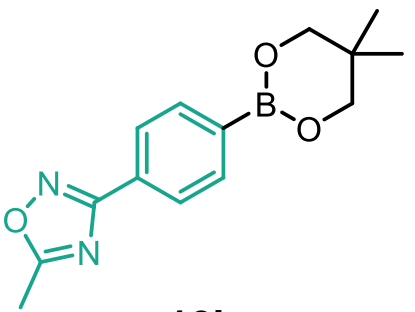

$10 \mathrm{~b}$

${ }^{13} \mathrm{C}$ NMR

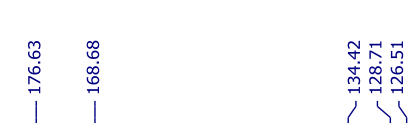

$\underset{\substack{0 \\ 0}}{\substack{0 \\ 0}}$

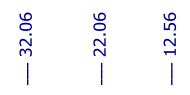

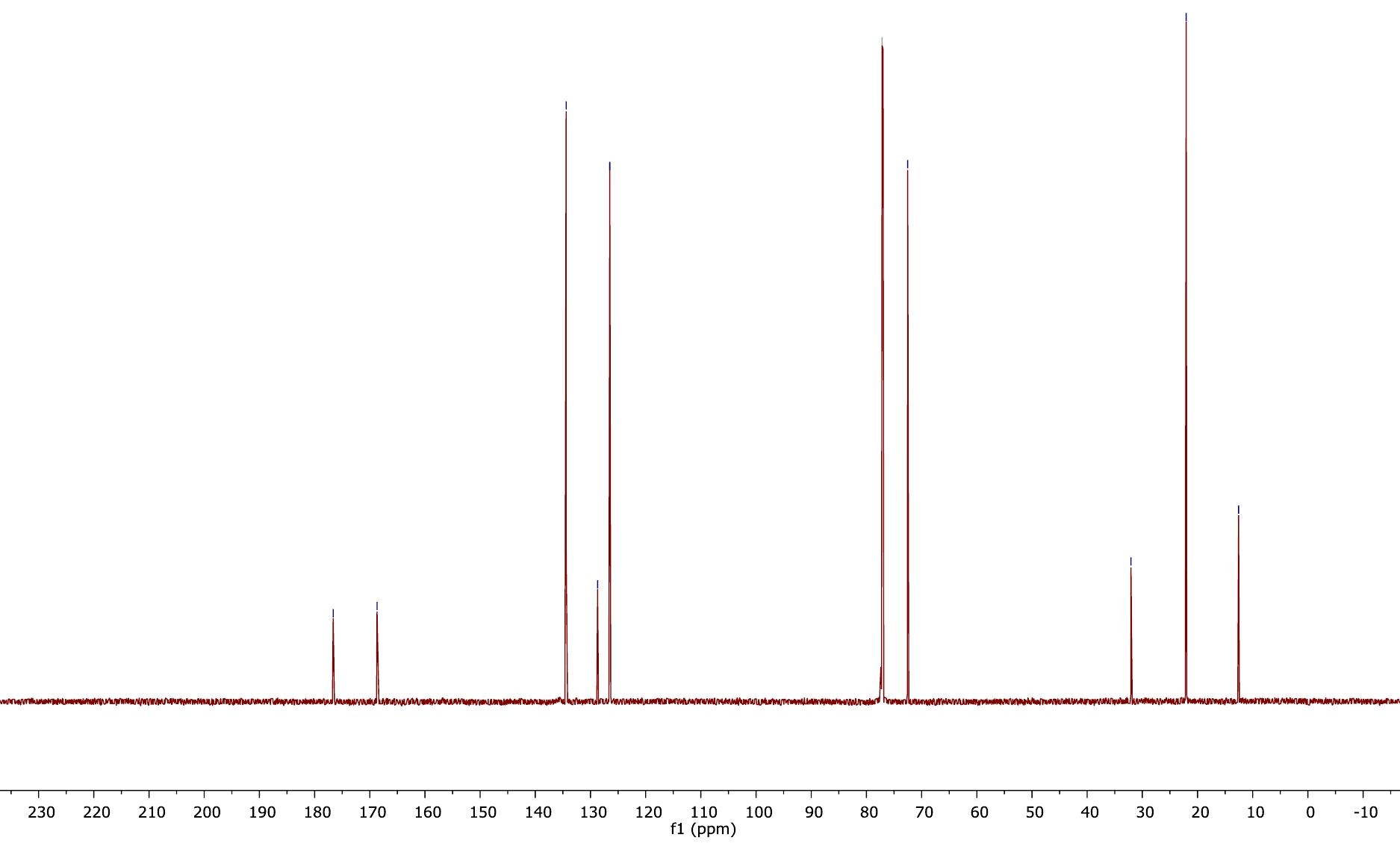




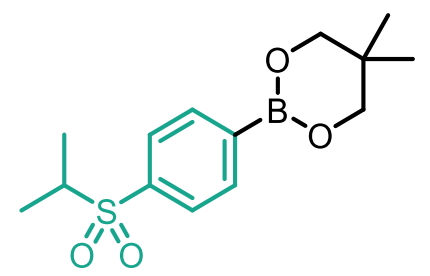

11b

${ }^{1} \mathrm{H}$ NMR

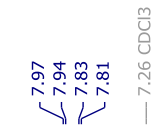

중욤ำำ

minmm

年

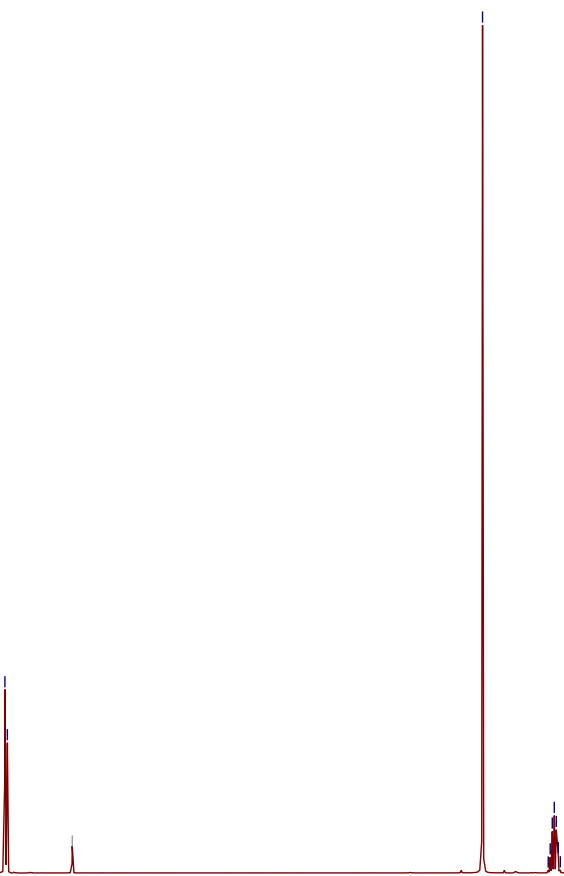

年览

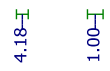

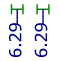

$\begin{array}{llll}12 & 11 & 10 & 9\end{array}$

8

$\begin{array}{cc}1 & 6 \\ & \mathrm{f} 1(\mathrm{ppm})\end{array}$




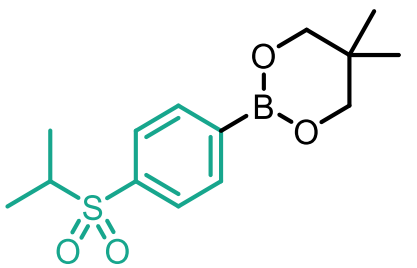

11b

${ }^{13} \mathrm{C}$ NMR

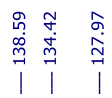

$m$
0
0
0

$$
\text { | }
$$

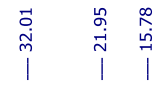

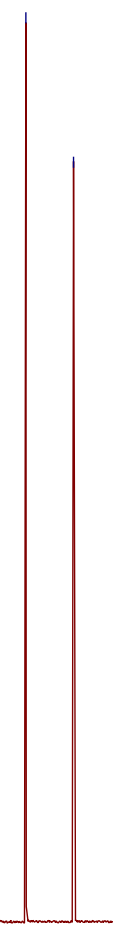

$\begin{array}{lllllllllllllllllllllllllll}230 & 220 & 210 & 200 & 190 & 180 & 170 & 160 & 150 & 140 & 130 & 120 & \begin{array}{c}110 \\ \mathrm{f} 1(\mathrm{ppm})\end{array} & 100 & 90 & 80 & 70 & 60 & 50 & 40 & 30 & 20 & 10 & 0 & -10\end{array}$




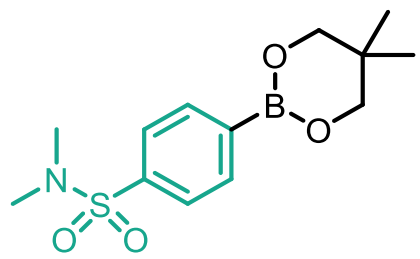

$12 b$

${ }^{1} \mathrm{H}$ NMR

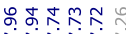

पर

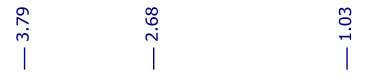

15


<smiles>CN(C)S(=O)(=O)c1ccc(B2OCC(C)(C)CO2)cc1</smiles>

$12 b$

${ }^{13} \mathrm{C}$ NMR

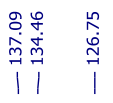

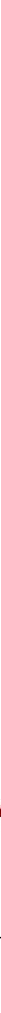




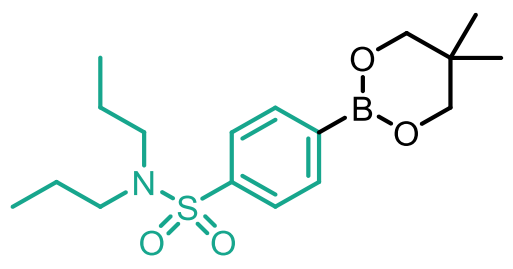

13b

${ }^{1} \mathrm{H}$ NMR

पा

|

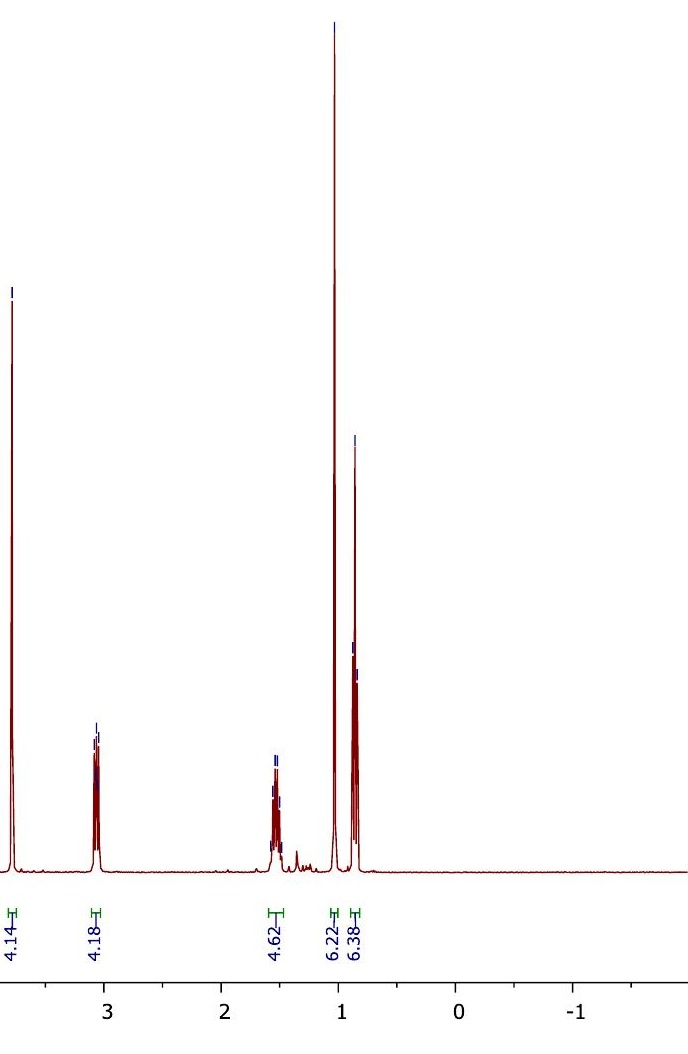


<smiles>CCCN(CCC)S(=O)(=O)c1ccc(B2OCC(C)(C)CO2)cc1</smiles>

13b

${ }^{13} \mathrm{C}$ NMR

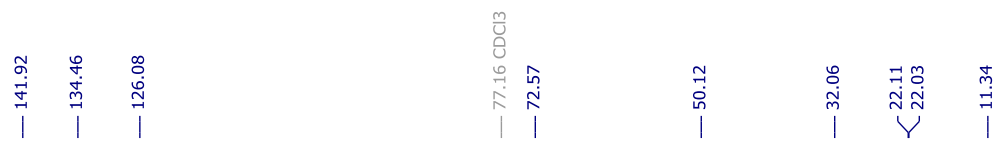


<smiles>CC1(C)COB(c2cc(C(F)(F)F)cc(S(C)(=O)=O)c2)OC1</smiles>

\section{$14 b$}

${ }^{13} \mathrm{C}$ NMR

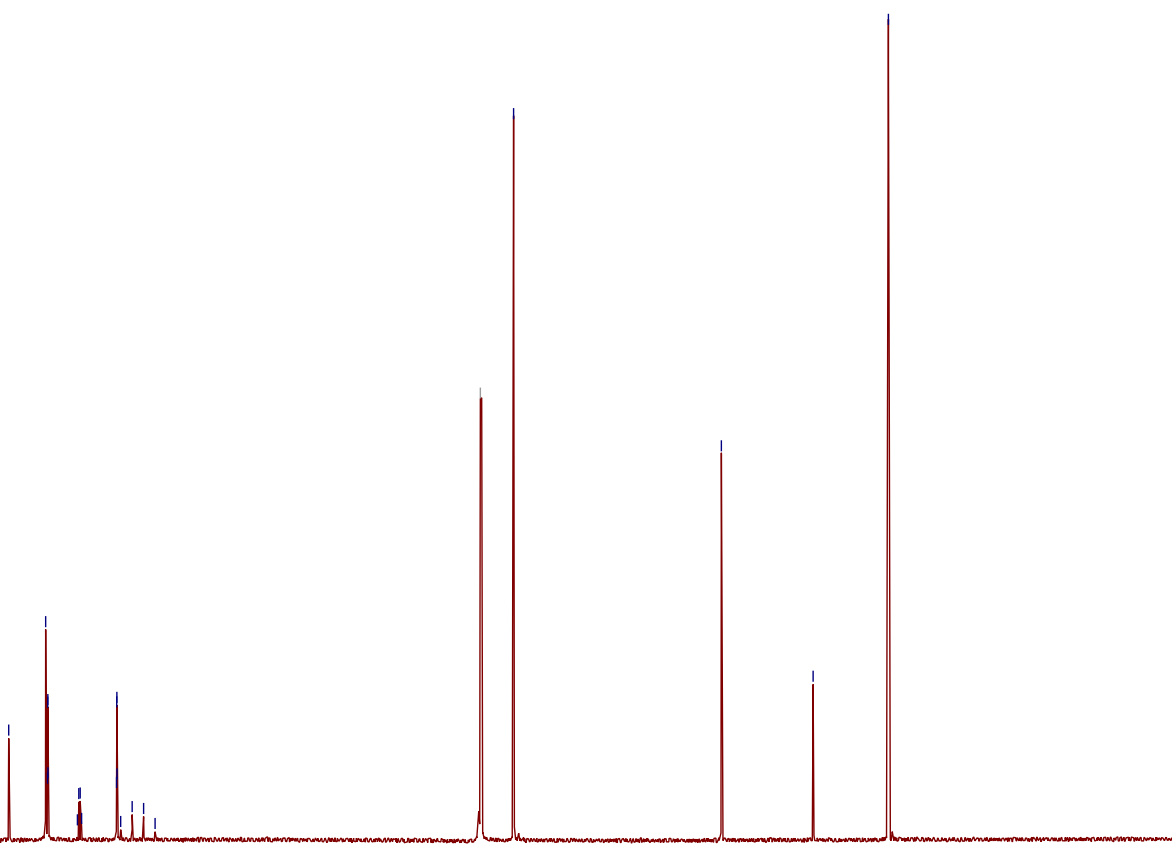

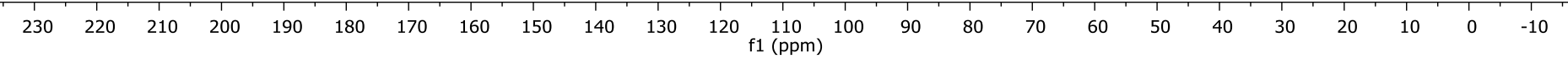




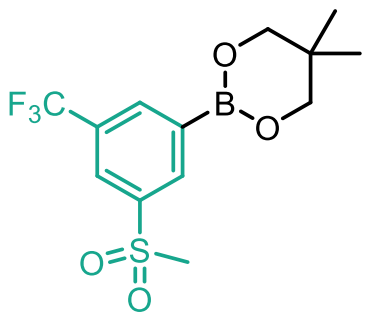

$14 b$

${ }^{19} \mathrm{~F}$ NMR

오ํ

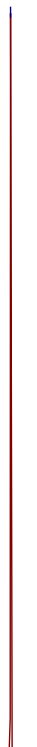

l 1

$\begin{array}{ll}10 & -20\end{array}$

$\begin{array}{llll} & & & 1 \\ -20 & -30 & -40 & -50\end{array}$

$-60$

$\begin{array}{ll}1 & -80 \\ -81 & -90\end{array}$ f1 (ppm) 


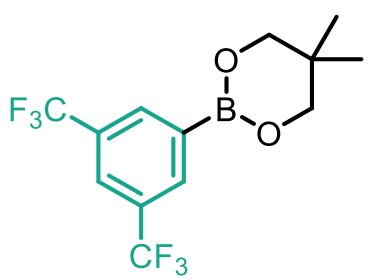

$15 b$

${ }^{1} \mathrm{H}$ NMR

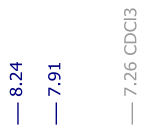
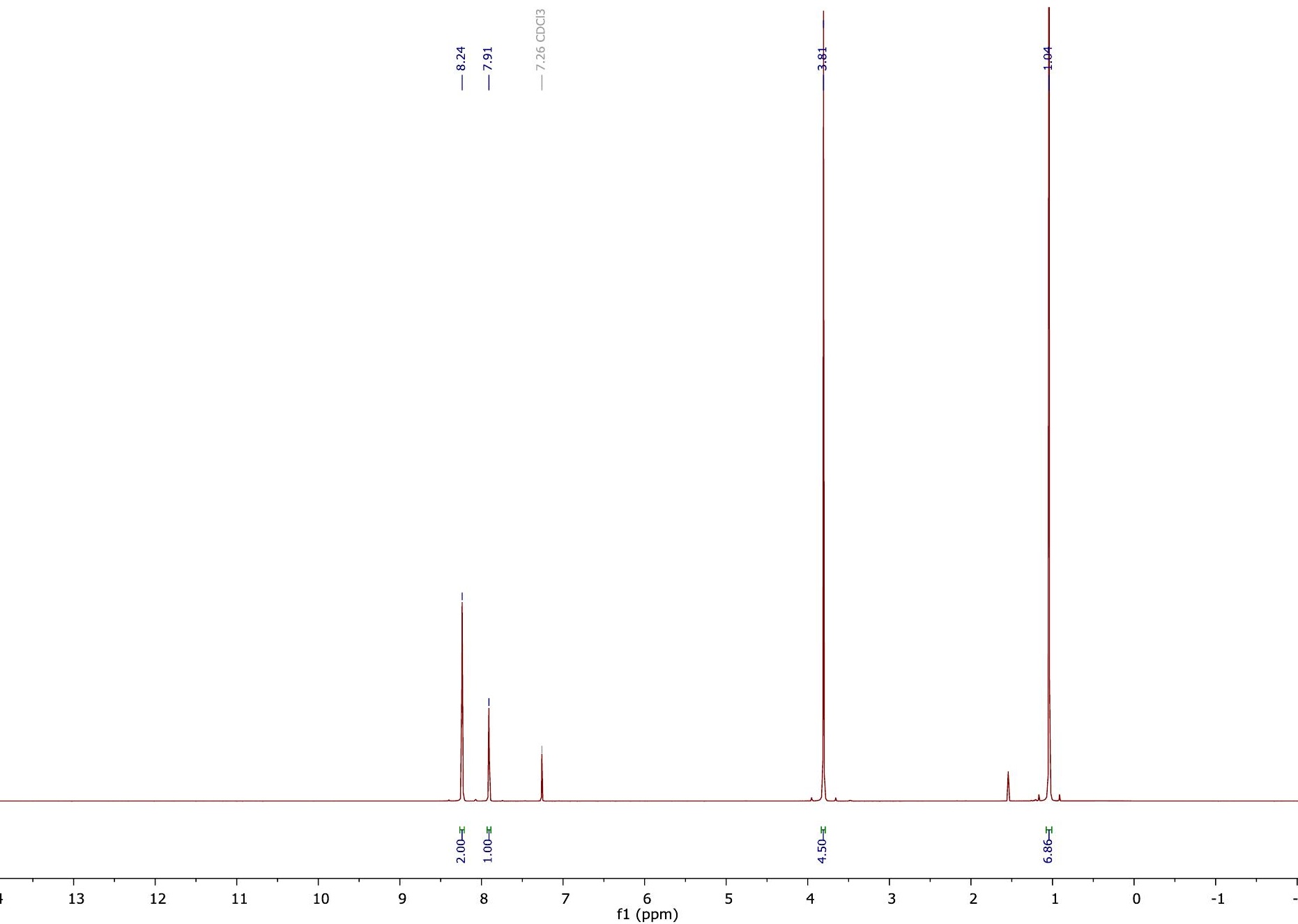
<smiles>CC1(C)COB(c2cc(C(F)(F)F)cc(C(F)(F)F)c2)OC1</smiles>

15b

${ }^{13} \mathrm{C}$ NMR

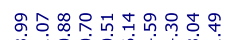

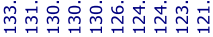

管

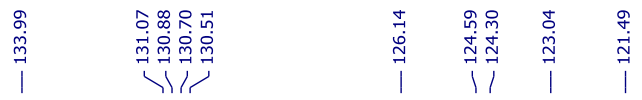

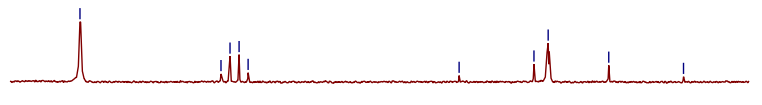

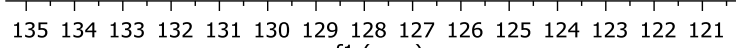
f1 (ppm)$$
\text { (ppm) }
$$

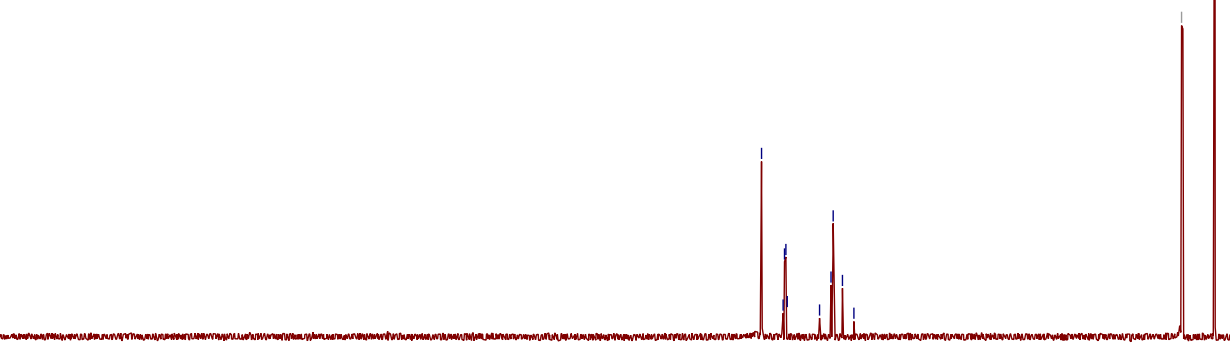

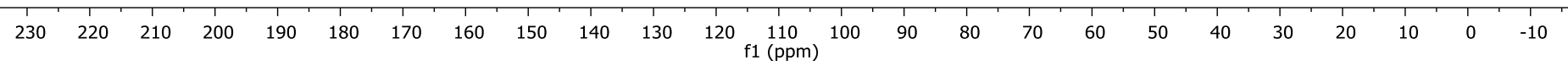


<smiles>CC1(C)COB(c2cc(C(F)(F)F)cc(C(F)(F)F)c2)OC1</smiles>

$15 b$

${ }^{19} \mathrm{~F}$ NMR

î

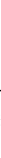




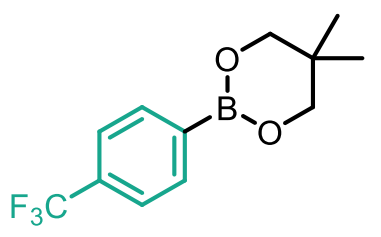

16b

${ }^{1} \mathrm{H}$ NMR

후옹ํํํํำ

VV

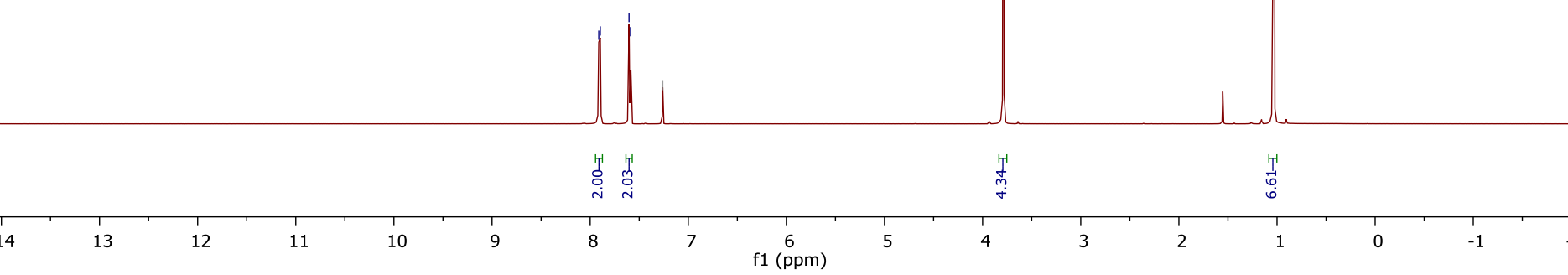


<smiles>CC1(C)COB(c2ccc(C(F)(F)F)cc2)OC1</smiles>

$16 b$

${ }^{13} \mathrm{C}$ NMR
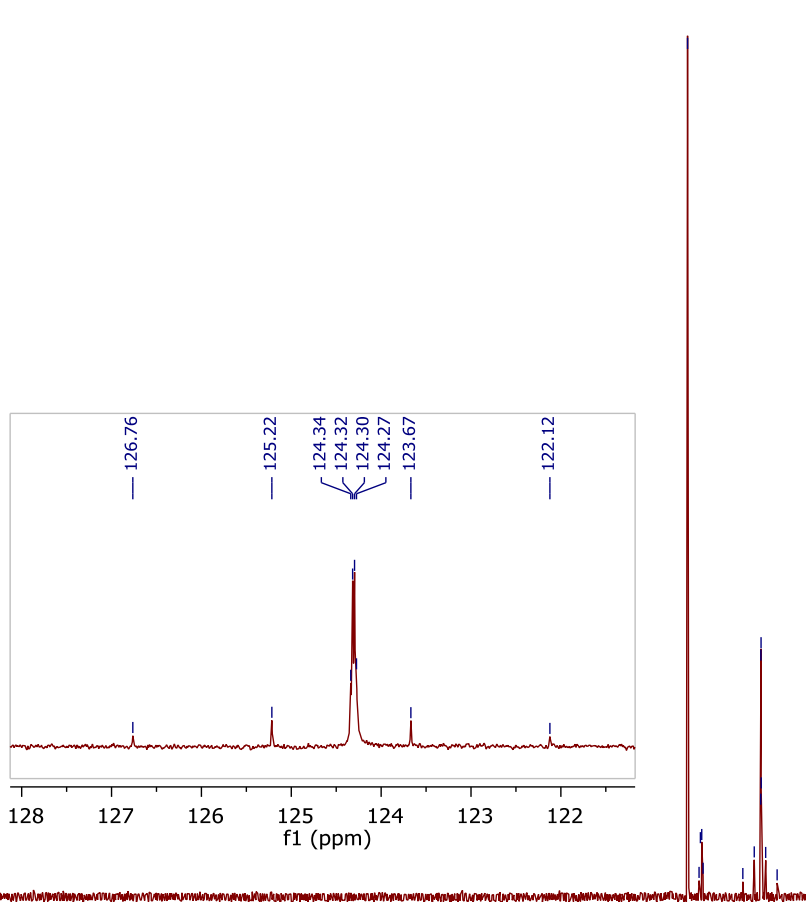

\begin{tabular}{|llllllllllllllllllllllllll}
$\mid$ & 230 & 220 & 210 & 200 & 190 & 180 & 170 & 160 & 150 & 140 & 130 & 120 & 110 & 100 & 90 & 80 & 70 & 60 & 50 & 40 & 30 & 20 & 10 & 0 & -10
\end{tabular}




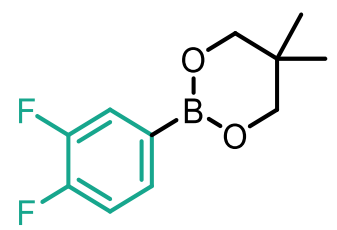

$17 b$

${ }^{1} \mathrm{H}$ NMR

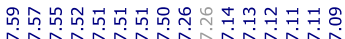

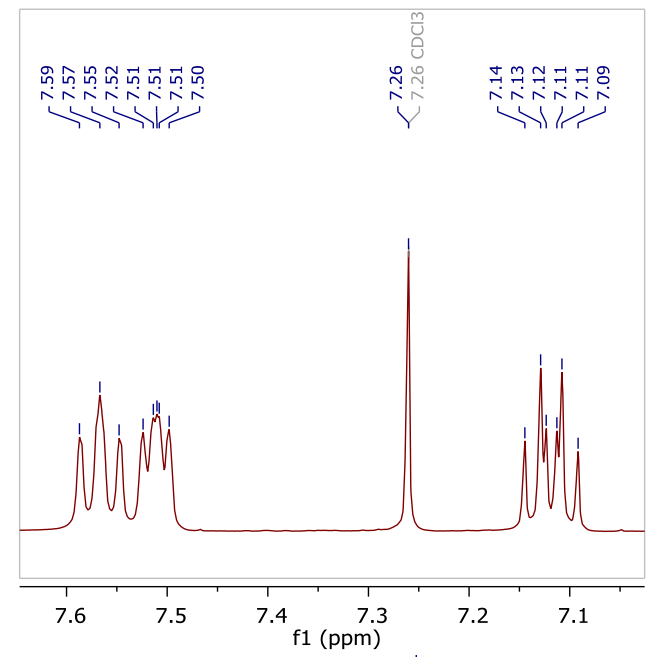

ii

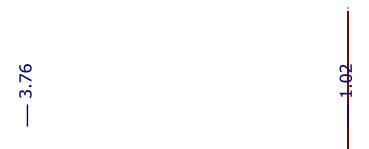

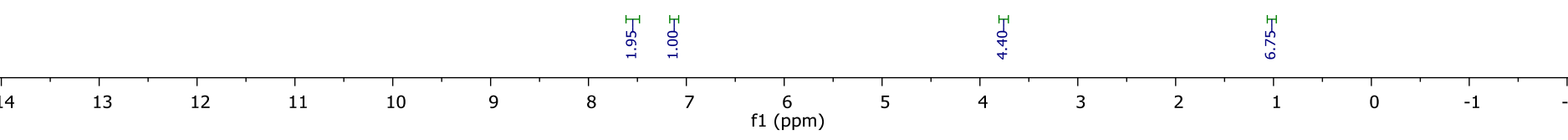


<smiles>CC1(C)COB(c2ccc(F)c(F)c2)OC1</smiles>

$17 \mathrm{~b}$

${ }^{13} \mathrm{C}$ NMR

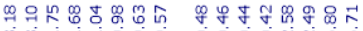

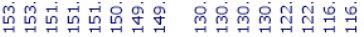

Y $Y$ 
<smiles>CC1(C)COB(c2ccc(F)c(F)c2)OC1</smiles>

$18 b$

${ }^{19} \mathrm{~F}$ NMR

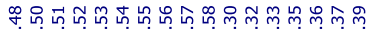

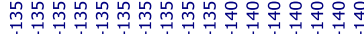

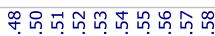

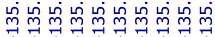

111111111

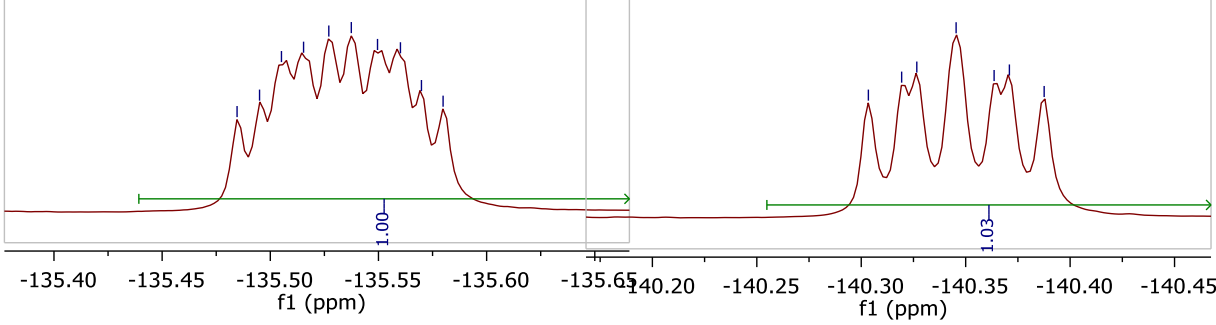

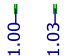

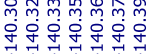

ijiji

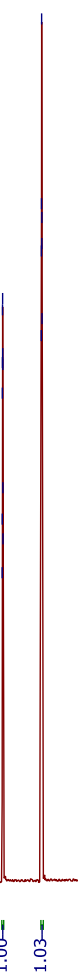

$20 \quad 10$

$10 \quad 0 \quad-10$

$-20 \quad-30$

$\begin{array}{llll}-30 & -40 & -50 & -60\end{array}$

$-60 \quad-70$
f1 (ppm)

\begin{tabular}{llllllll}
\hline & & & & & & \\
\hline & -150 & -160 & -170 & -180 & -190 & -2
\end{tabular}




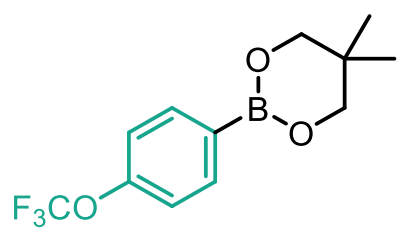

$19 b$

${ }^{1} \mathrm{H}$ NMR

㐫

我

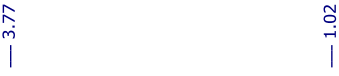

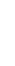


<smiles>CC1(C)COB(c2ccc(OC(F)(F)F)cc2)OC1</smiles>

\section{$19 b$}

${ }^{13} \mathrm{C}$ NMR

|

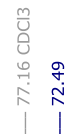

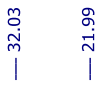

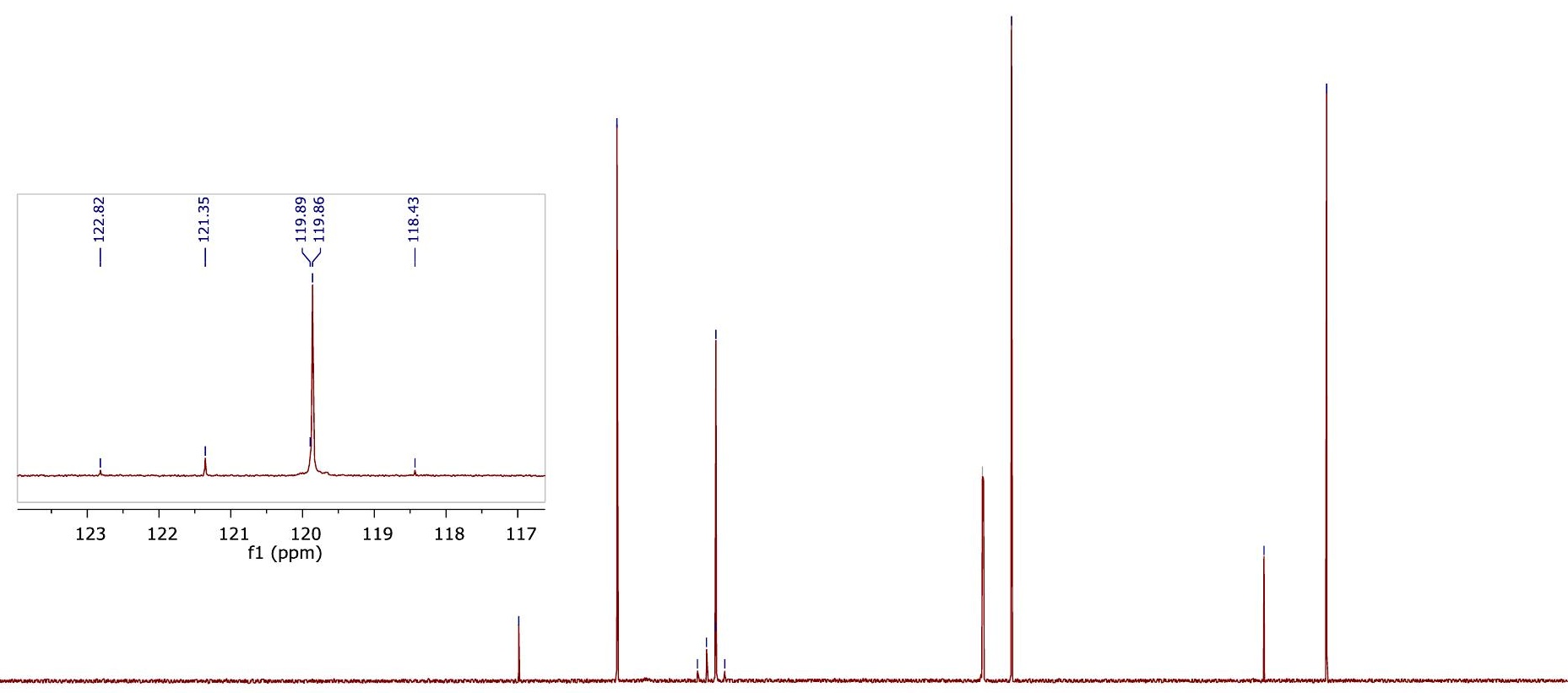

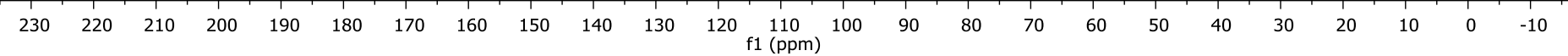




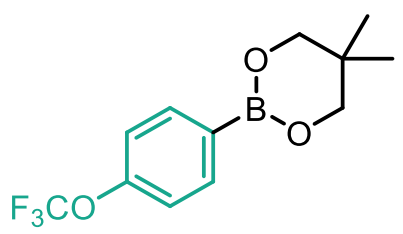

$19 b$

${ }^{19} \mathrm{~F}$ NMR

$\stackrel{\substack{\text { m } \\ \text { in } \\ i}}{i}$

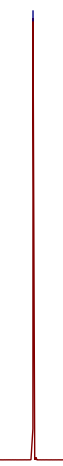

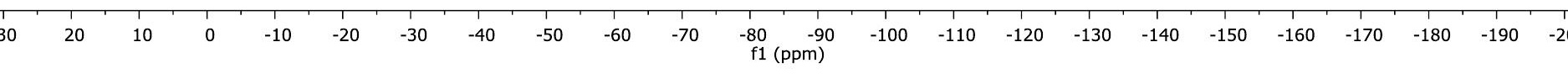




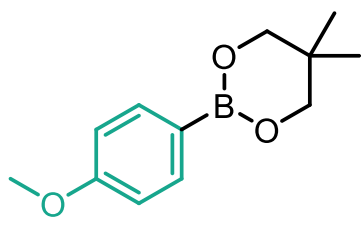

$19 b$

${ }^{1} \mathrm{H}$ NMR

岱

$\prod_{j}^{\infty}$

i

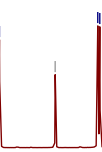

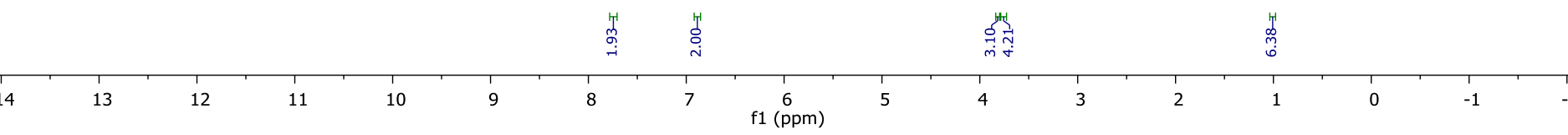


<smiles>COc1ccc(B2OCC(C)(C)CO2)cc1</smiles>

$19 b$

${ }^{13} \mathrm{C}$ NMR

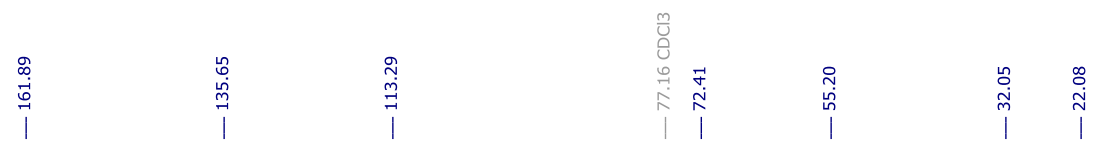

\begin{tabular}{|c|c|c|c|c|c|c|c|c|c|c|c|c|c|c|c|c|c|c|c|c|c|c|c|c|}
\hline 230 & 220 & 210 & 200 & 190 & 180 & 170 & 160 & 150 & 140 & 130 & 120 & $\begin{array}{c}110 \\
\mathrm{f} 1(\mathrm{ppm})\end{array}$ & 100 & 90 & 80 & 70 & 60 & 50 & 40 & 30 & 20 & 10 & 0 & -10 \\
\hline
\end{tabular}


<smiles>N#Cc1ccc(C(F)F)cc1</smiles>

\section{1}

${ }^{1} \mathrm{H}$ NMR

象

परे।

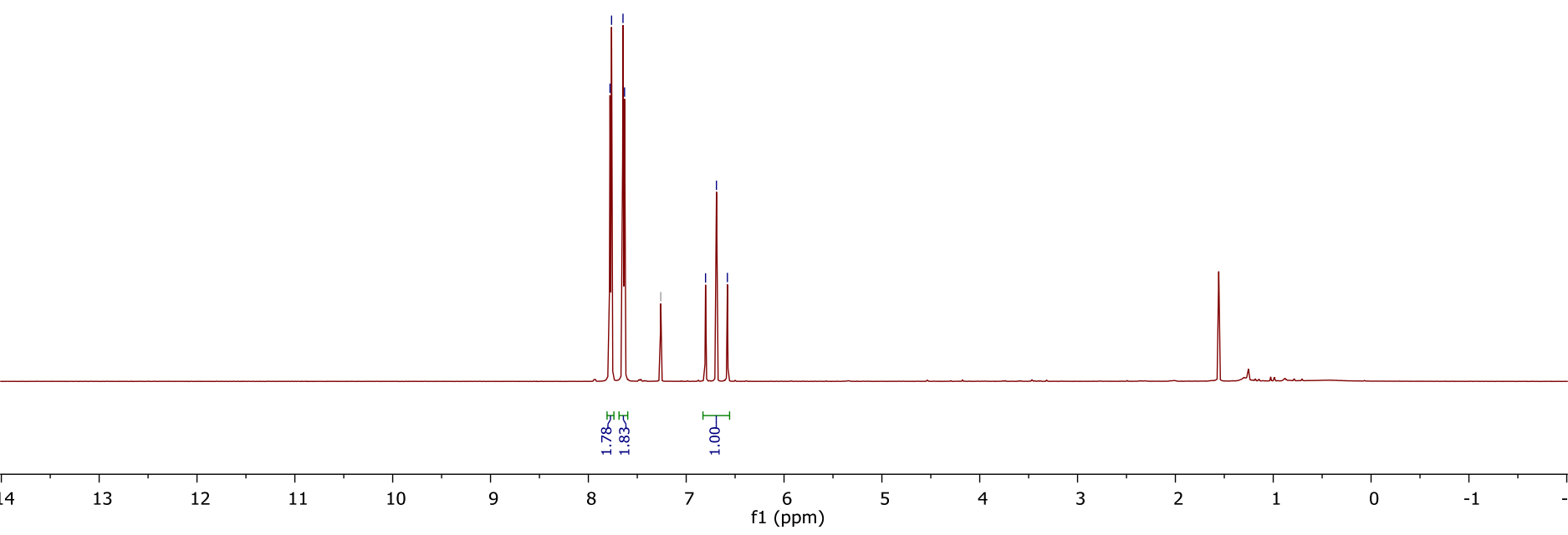


<smiles>N#Cc1ccc(C(F)F)cc1</smiles>

${ }^{13} \mathrm{C}$ NMR

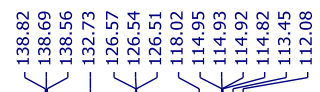

$\underbrace{\substack{\infty \\ \infty}}_{\substack{\infty \\ \infty}}$

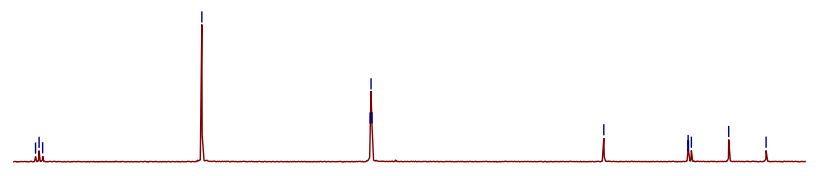

$\begin{array}{llllllllllllll}138 & 136 & 134 & 132 & 130 & 128 & 126 & 124 & 122 & 120 & 118 & 116 & 114 & 112\end{array}$ f1 (ppm)

\begin{tabular}{|c|c|c|c|c|c|c|c|c|c|c|c|c|c|c|c|c|c|c|c|c|c|c|c|c|}
\hline 230 & 220 & 210 & 200 & 190 & 180 & 170 & 160 & 150 & 140 & 130 & 120 & $\begin{array}{c}110 \\
\mathrm{f} 1(\mathrm{ppm})\end{array}$ & 100 & 90 & 80 & 70 & 60 & 50 & 40 & 30 & 20 & 10 & 0 & -10 \\
\hline
\end{tabular}


<smiles>N#Cc1ccc(C(F)F)cc1</smiles>

${ }^{19} \mathrm{~F}$ NMR

ำ 
<smiles>Cc1cc(C(F)F)ccc1C#N</smiles>

2

${ }^{1} \mathrm{H}$ NMR

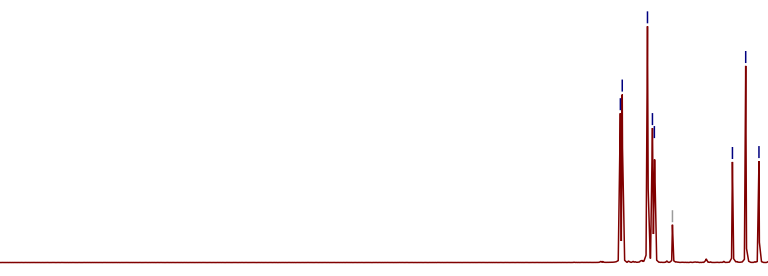

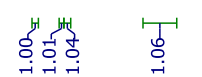

ले 
<smiles>Cc1cc(C(F)F)ccc1C#N</smiles>

\section{2}

${ }^{13} \mathrm{C}$ NMR

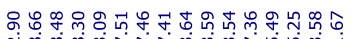

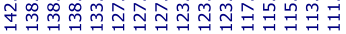

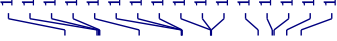
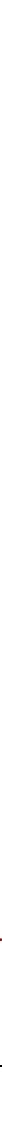
<smiles>Cc1cc(C(F)F)ccc1C#N</smiles>

2

${ }^{19} \mathrm{~F}$ NMR

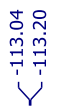

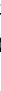




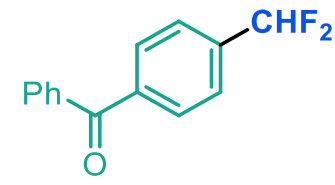

3

${ }^{1} \mathrm{H}$ NMR
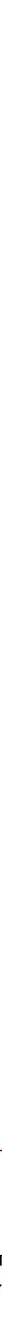
<smiles>O=C(c1ccccc1)c1ccc(C(F)F)cc1</smiles>

3

${ }^{13} \mathrm{C}$ NMR

\begin{tabular}{l}
\multirow{0}{0}{} \\
$\dot{0}$ \\
\multirow{7}{|}{}
\end{tabular}

$\infty$ ๓ ํำ

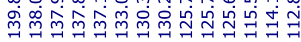

议以

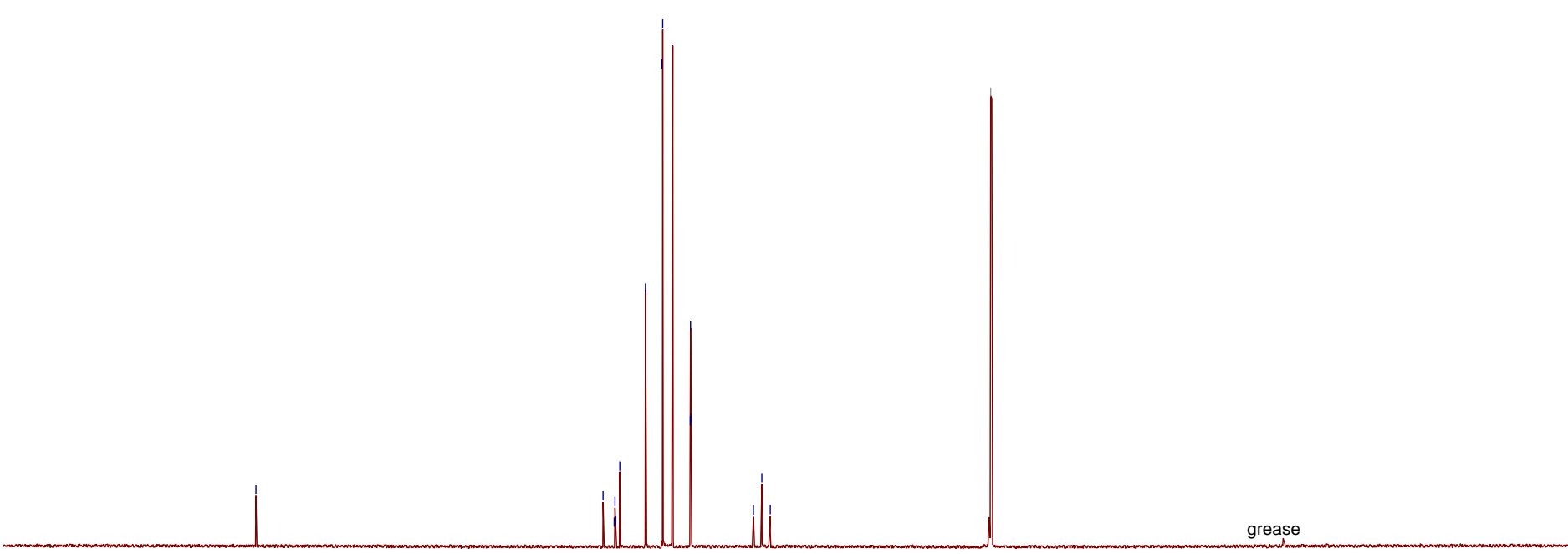


<smiles>O=C(c1ccccc1)c1ccc(C(F)F)cc1</smiles>

3

${ }^{19} \mathrm{~F}$ NMR

ن

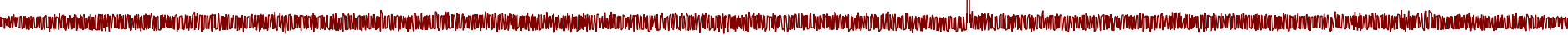


<smiles>CCCC(=O)c1ccc(C(F)F)cc1</smiles>

4

${ }^{1} \mathrm{H}$ NMR

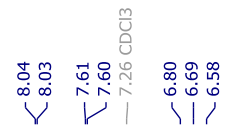

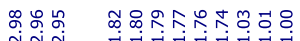

证 岛 
<smiles>CCCC(=O)c1ccc(C(F)F)cc1</smiles>

\section{4 \\ ${ }^{13} \mathrm{C}$ NMR}

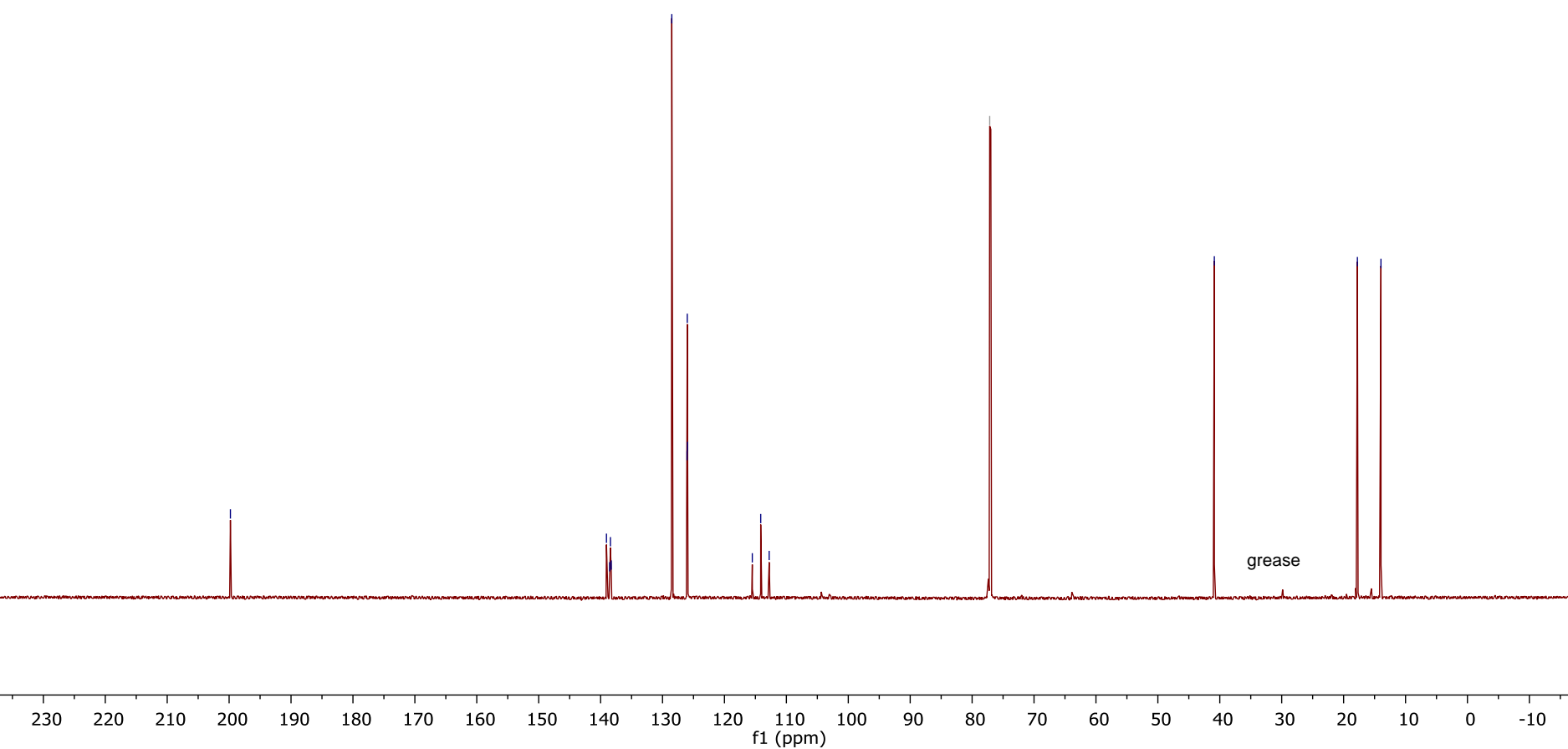


<smiles>CCCC(=O)c1ccc(C(F)F)cc1</smiles>

4

${ }^{19} \mathrm{~F}$ NMR

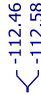

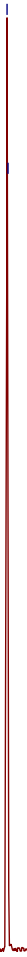

\begin{tabular}{|c|c|c|c|c|c|c|c|c|c|c|c|c|c|c|c|c|c|c|c|c|}
\hline 1 & 1 & $T$ & 1 & 1 & 1 & 1 & 1 & 1 & 1 & 1,1 & 1 & 1 & 1 & 1 & 1 & 1 & 1 & 1 & 1 & 1 \\
\hline 20 & 10 & 0 & -10 & -20 & -30 & -40 & -50 & -60 & -70 & $\begin{array}{cc}-80 & -90 \\
\mathrm{f1} & (\mathrm{ppm})\end{array}$ & -100 & -110 & -120 & -130 & -140 & -150 & -160 & -170 & -180 & -190 \\
\hline
\end{tabular}


<smiles>O=C1c2ccccc2C(=O)c2cc(C(F)F)ccc21</smiles>

5

${ }^{1} \mathrm{H}$ NMR
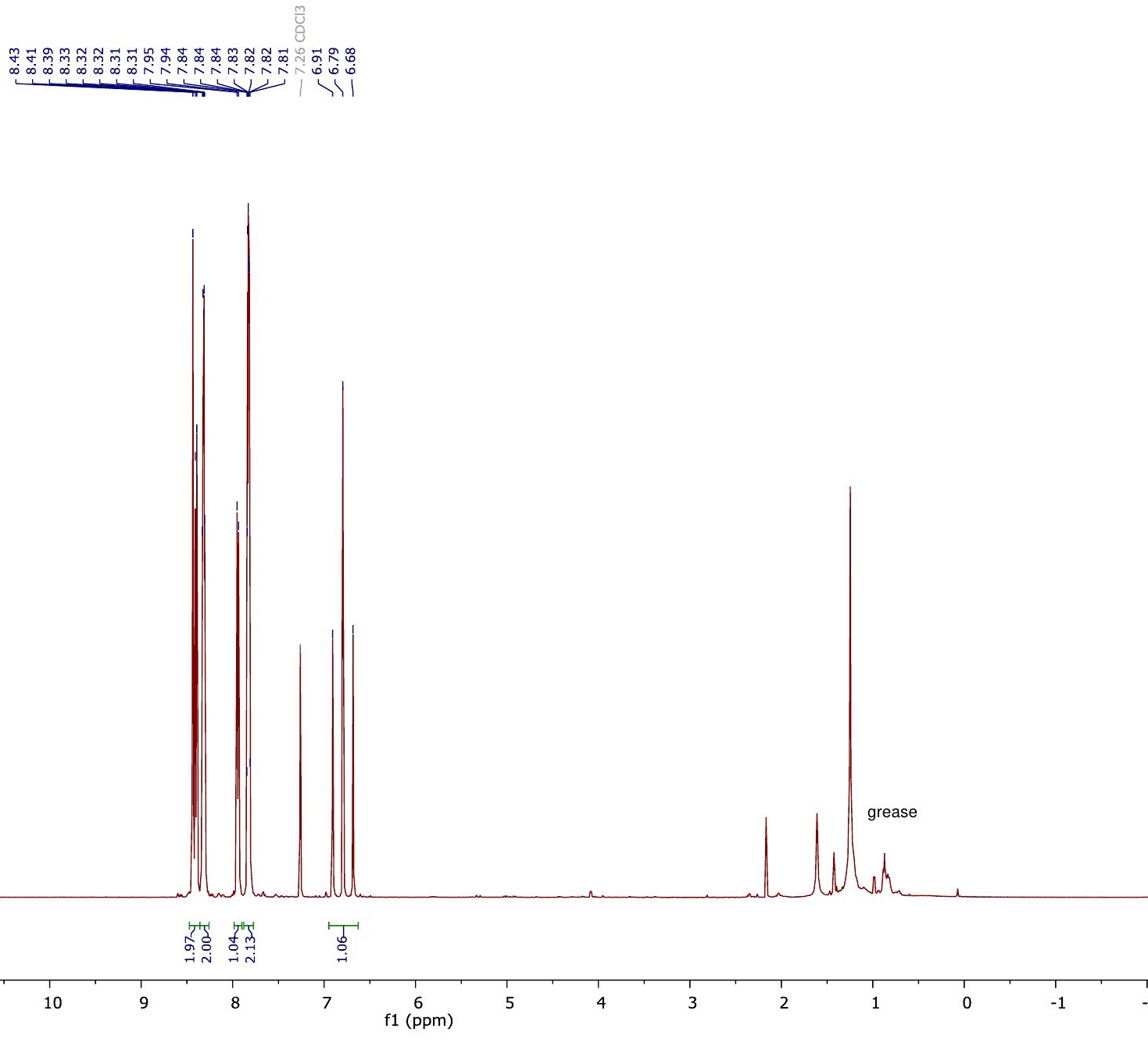
<smiles>O=C1c2ccccc2C(=O)c2cc(C(F)F)ccc21</smiles>

5

${ }^{13} \mathrm{C}$ NMR

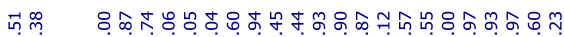

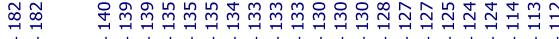

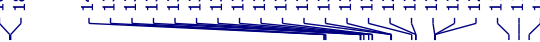

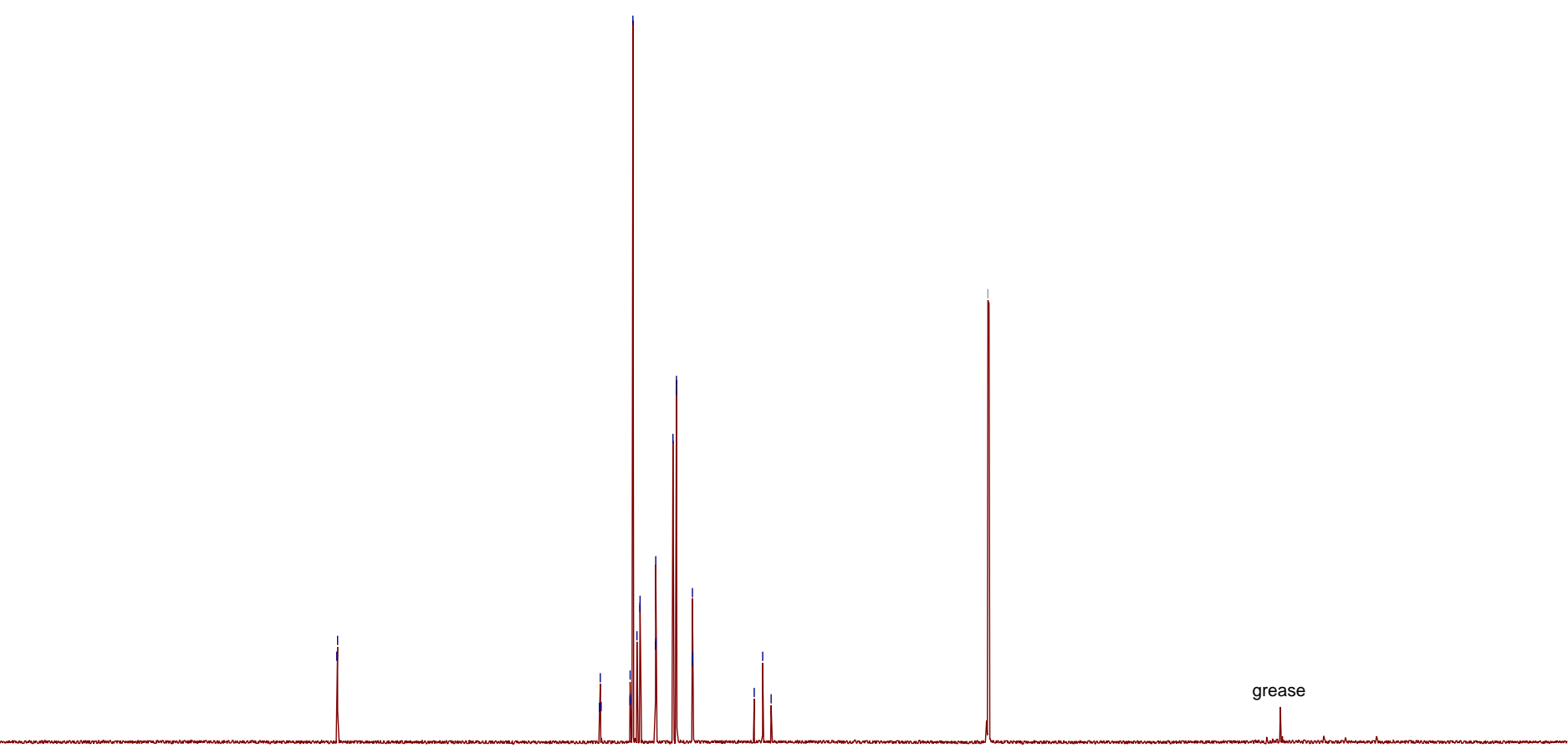

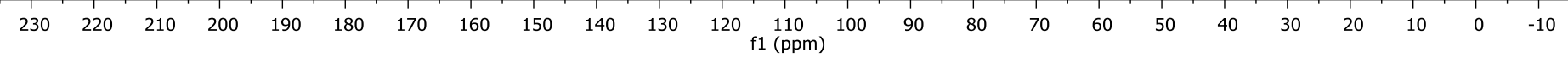


<smiles>O=C1c2ccccc2C(=O)c2cc(C(F)F)ccc21</smiles>

5

${ }^{19} \mathrm{~F}$ NMR

ن

\begin{tabular}{llllllllllllllllllllllllllllll}
\hline 30 & 20 & 10 & 0 & -10 & -20 & -30 & -40 & -50 & -60 & -70 & -80 & -90 & -100 & -110 & -120 & -130 & -140 & -150 & -160 & -170 & -180 & -190 & -200
\end{tabular}


<smiles>CCOC(=O)c1ccc(C(F)F)cc1</smiles>

6

${ }^{1} \mathrm{H}$ NMR

눙

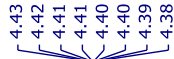

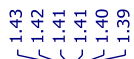

W

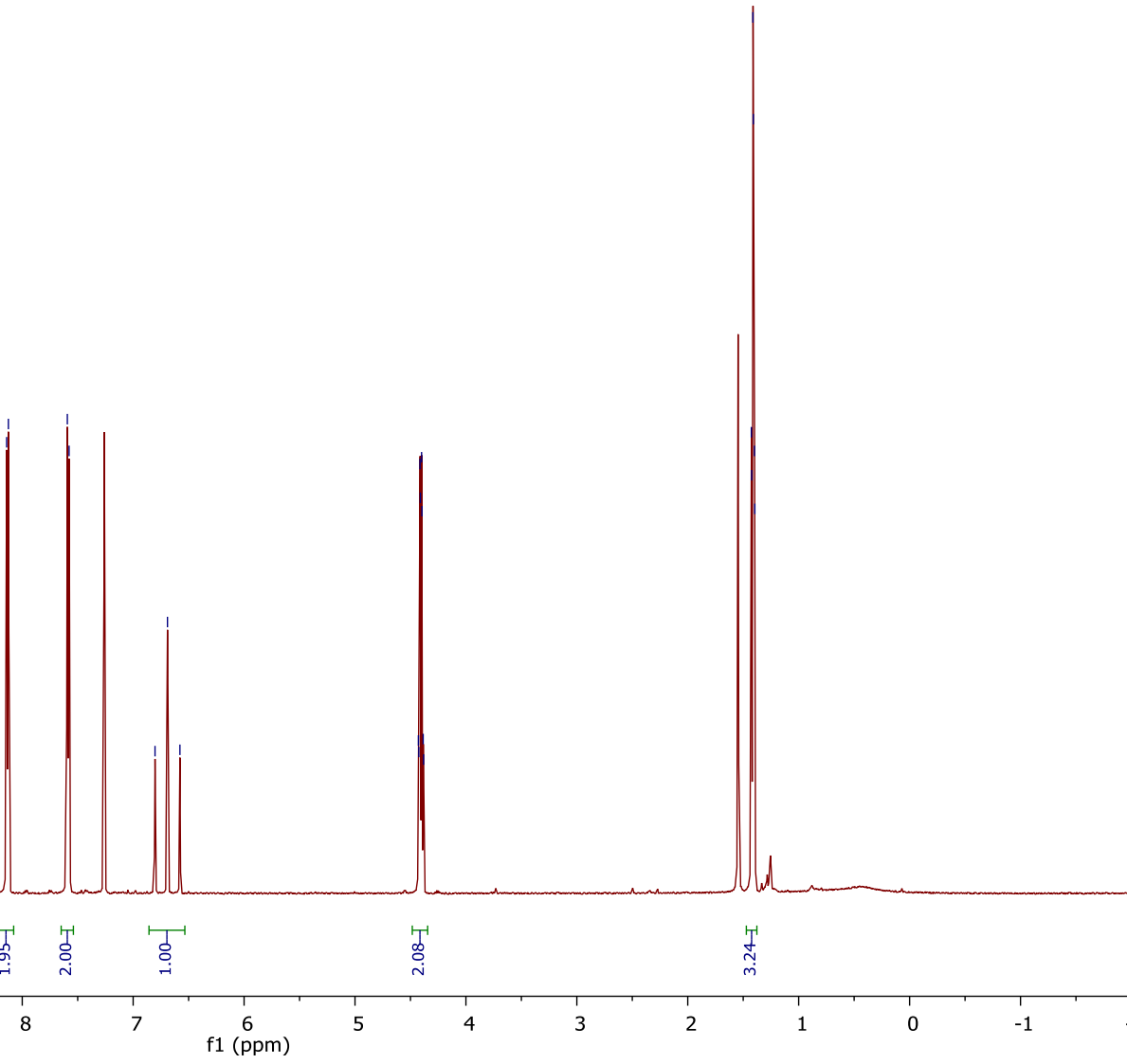


<smiles>CCOC(=O)c1ccc(C(F)F)cc1</smiles>

6 ${ }^{13} \mathrm{C}$ NMR
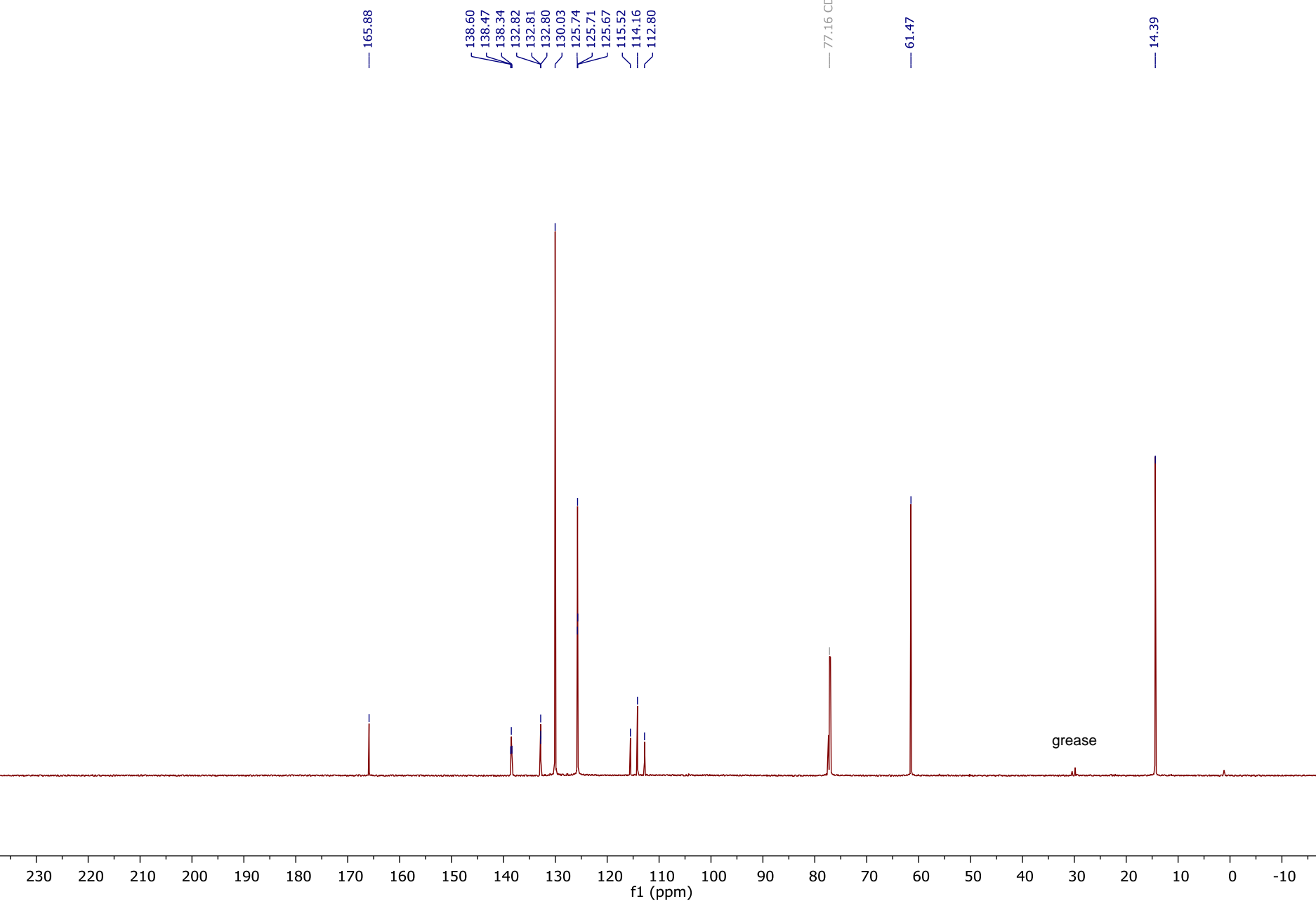
<smiles>CCOC(=O)c1ccc(C(F)F)cc1</smiles>

6

${ }^{19} \mathrm{~F}$ NMR

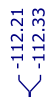

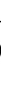


<smiles>COC(=O)c1ccc(C(F)F)cc1</smiles>

\section{7}

${ }^{1} \mathrm{H}$ NMR

V)

খั

grease

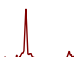

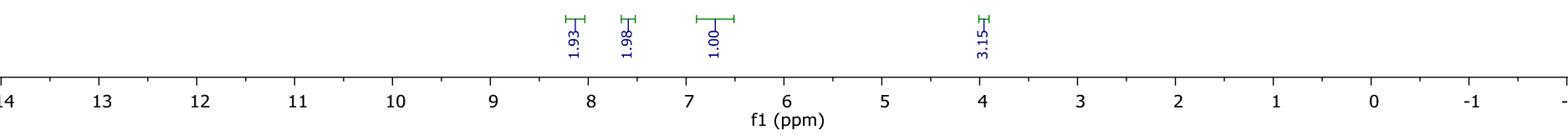


<smiles>COC(=O)c1ccc(C(F)F)cc1</smiles>

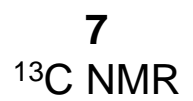

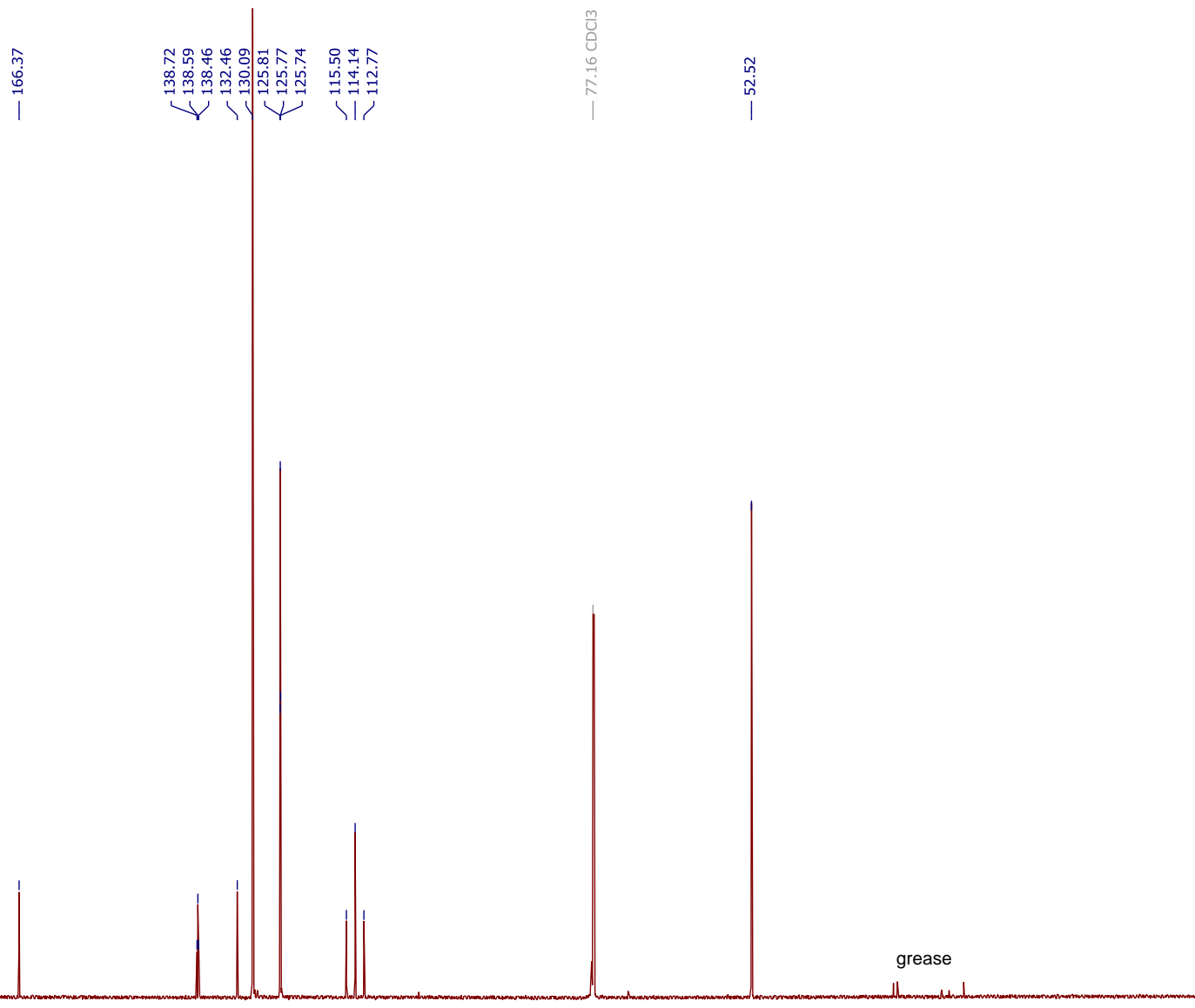

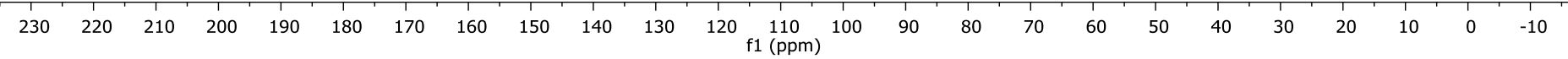


<smiles>COC(=O)c1ccc(C(F)F)cc1</smiles>

7 ${ }^{19} \mathrm{~F}$ NMR

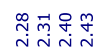

กี่ 7 구

范

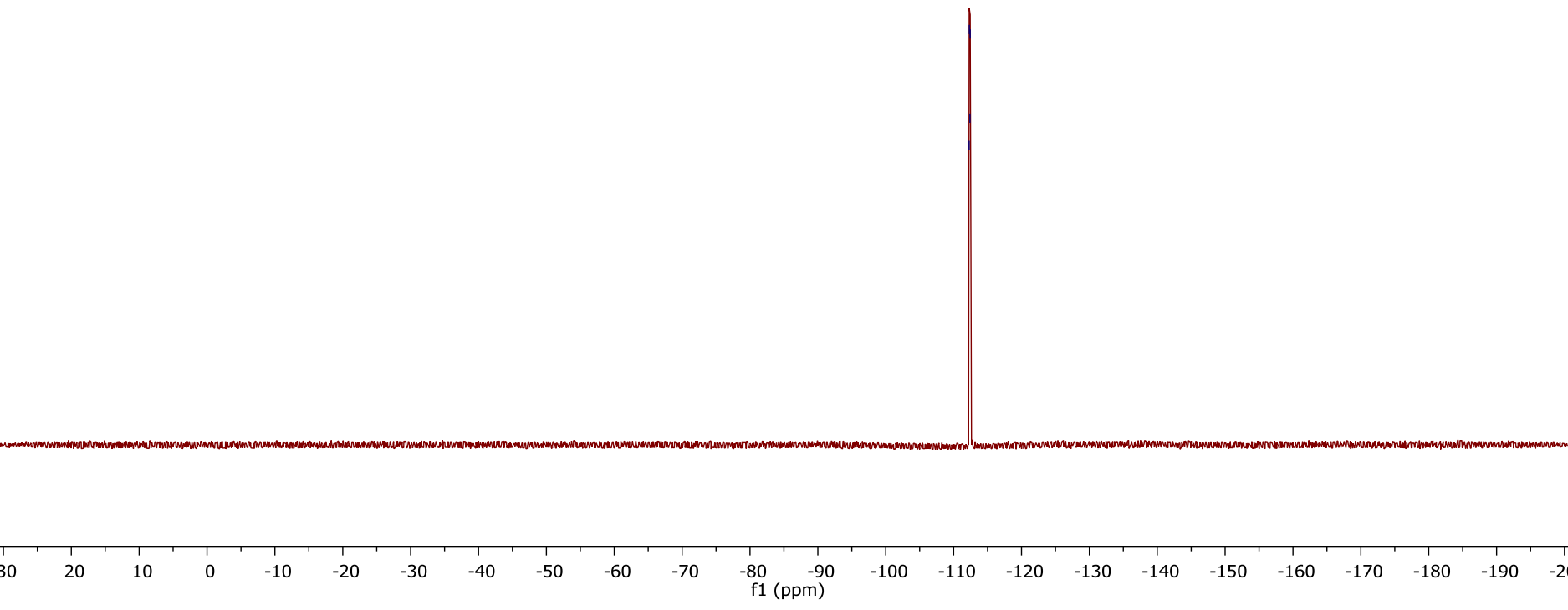


<smiles>CCOC(=O)c1cc(C(=O)OCC)cc(C(F)F)c1</smiles>

8

${ }^{1} \mathrm{H}$ NMR

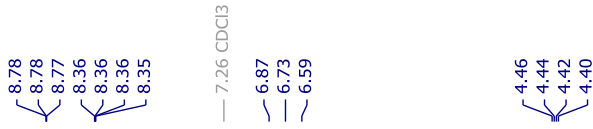

لإن

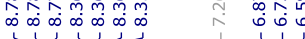

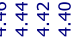


<smiles>CCOC(=O)c1cc(C(=O)OCC)cc(C(F)F)c1</smiles>

8

${ }^{13} \mathrm{C}$ NMR

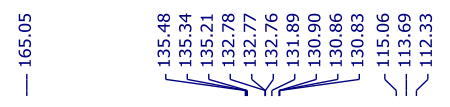

\begin{tabular}{|c|c|c|c|c|c|c|c|c|c|c|c|c|c|c|c|c|c|c|c|c|c|c|c|c|c|c|}
\hline 230 & 220 & 21 & & 200 & 190 & 180 & 170 & 160 & 150 & 140 & 130 & 120 & $\begin{array}{c}110 \\
\mathrm{f} 1(\mathrm{ppm})\end{array}$ & 100 & 90 & 80 & 70 & & 0 & 50 & 40 & 30 & 20 & 10 & 0 & -10 \\
\hline
\end{tabular}


<smiles>CCOC(=O)c1cc(C(=O)OCC)cc(C(F)F)c1</smiles>

8

${ }^{19} \mathrm{~F}$ NMR

ن

\begin{tabular}{llllllllllllllllllllllllllll}
\hline 30 & 20 & 10 & 0 & -10 & -20 & -30 & -40 & -50 & -60 & -70 & -80 & -90 & -100 & -110 & -120 & -130 & -140 & -150 & -160 & -170 & -180 & -190 & -200
\end{tabular}




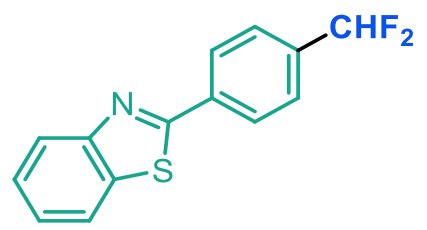

9

${ }^{1} \mathrm{H}$ NMR

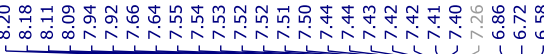
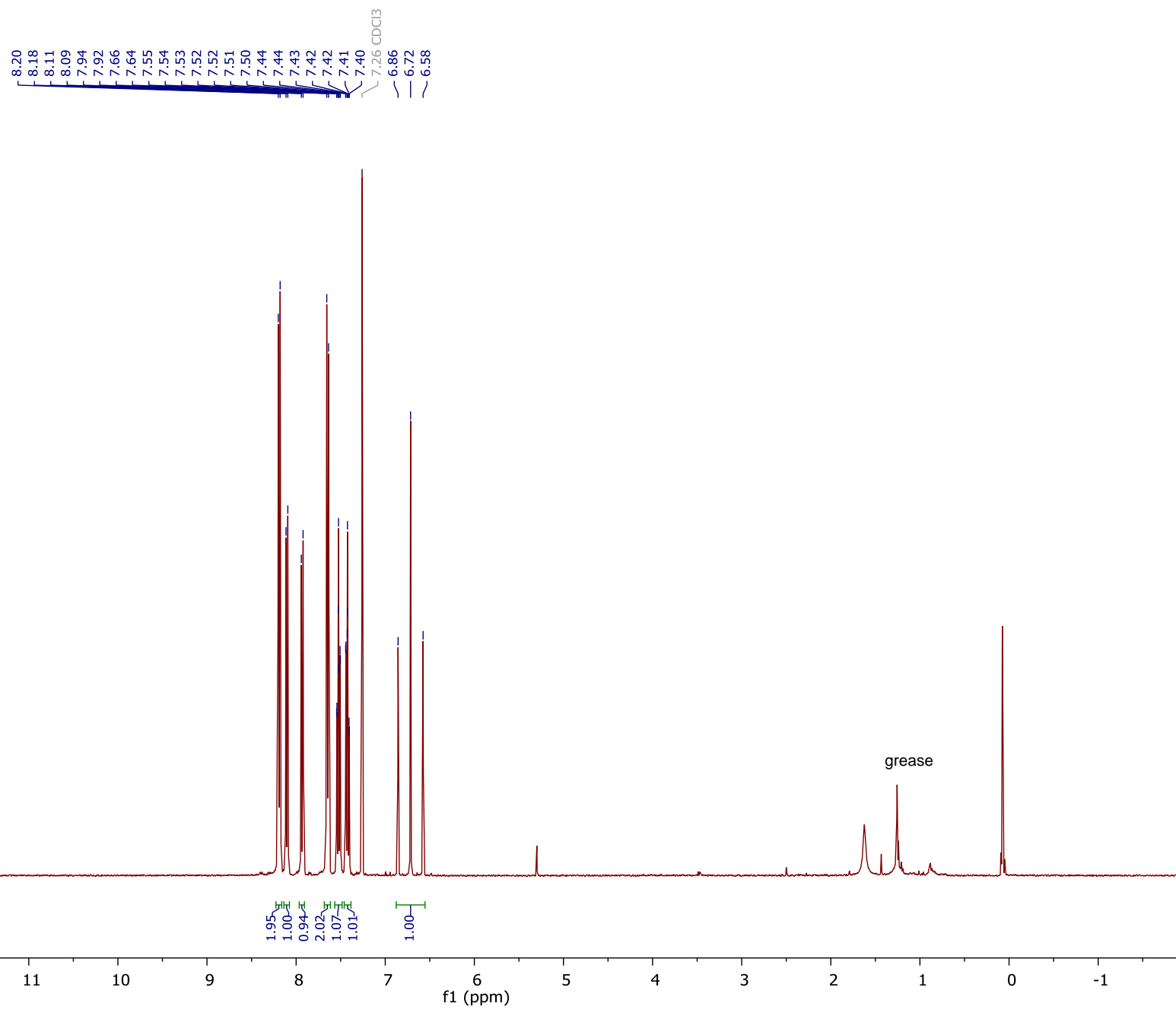
<smiles>FC(F)c1ccc(-c2nc3ccccc3s2)cc1</smiles>

9

${ }^{13} \mathrm{C}$ NMR
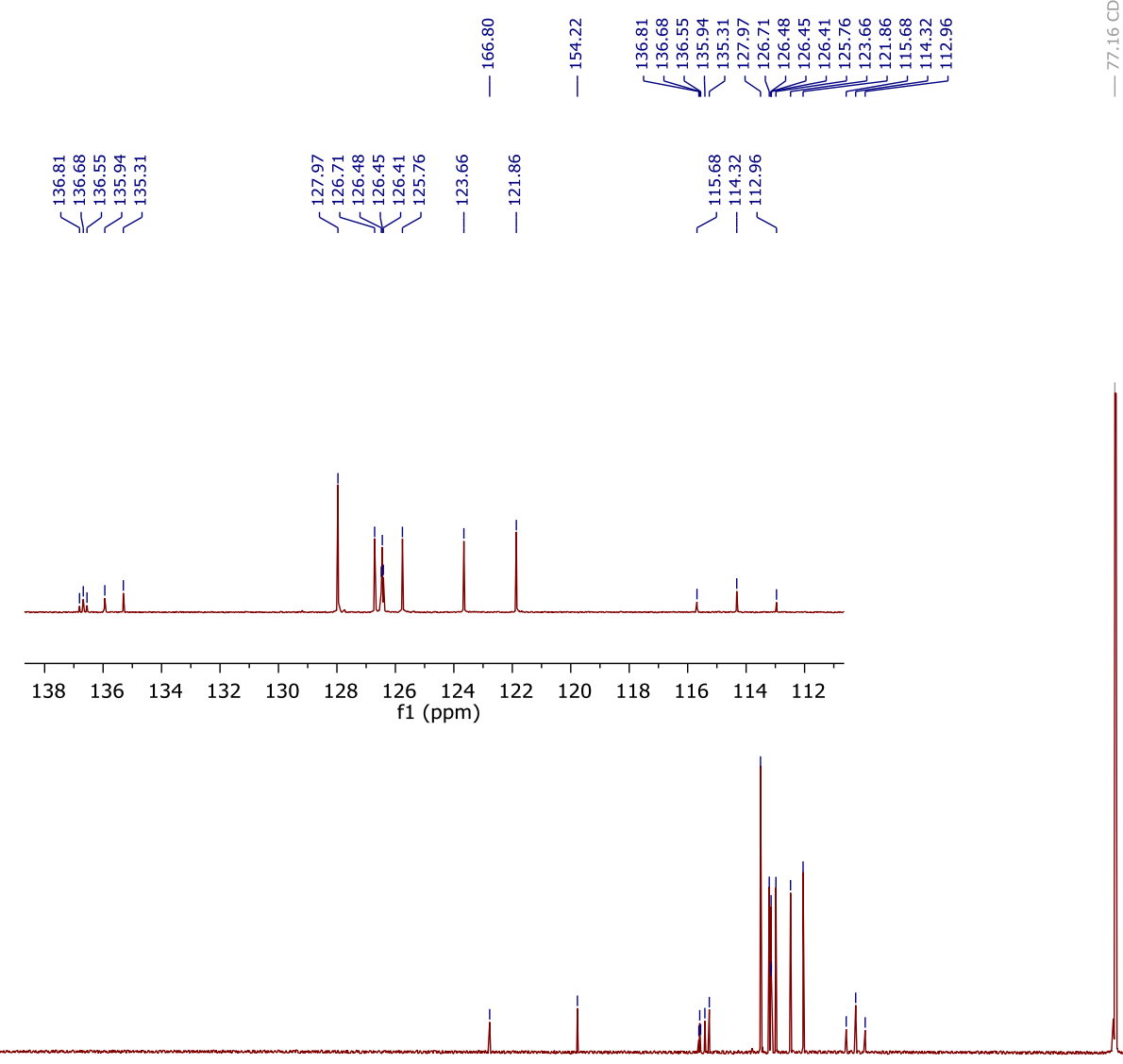

grease

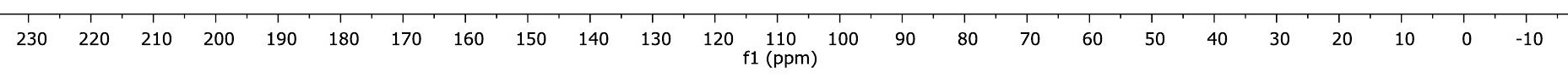




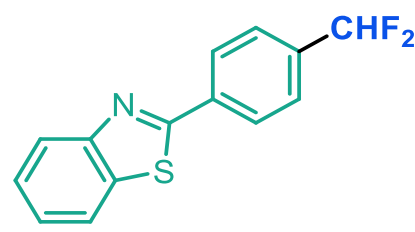

9

${ }^{19} \mathrm{~F}$ NMR

v

30

$20 \quad 10$

$-10,-20$

$-20-30 \quad-40$

$\begin{array}{lll}-50 & -60 & -70\end{array}$

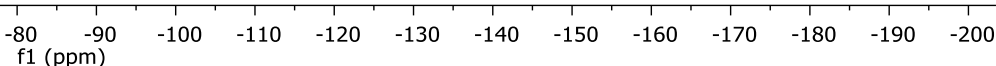




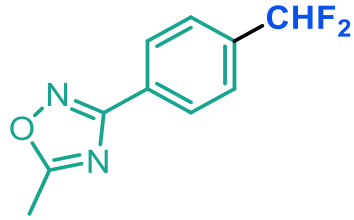

10

${ }^{1} \mathrm{H}$ NMR

V

T is is is is


<smiles>Cc1nc(-c2ccc(C(F)F)cc2)no1</smiles>

10

${ }^{13} \mathrm{C}$ NMR
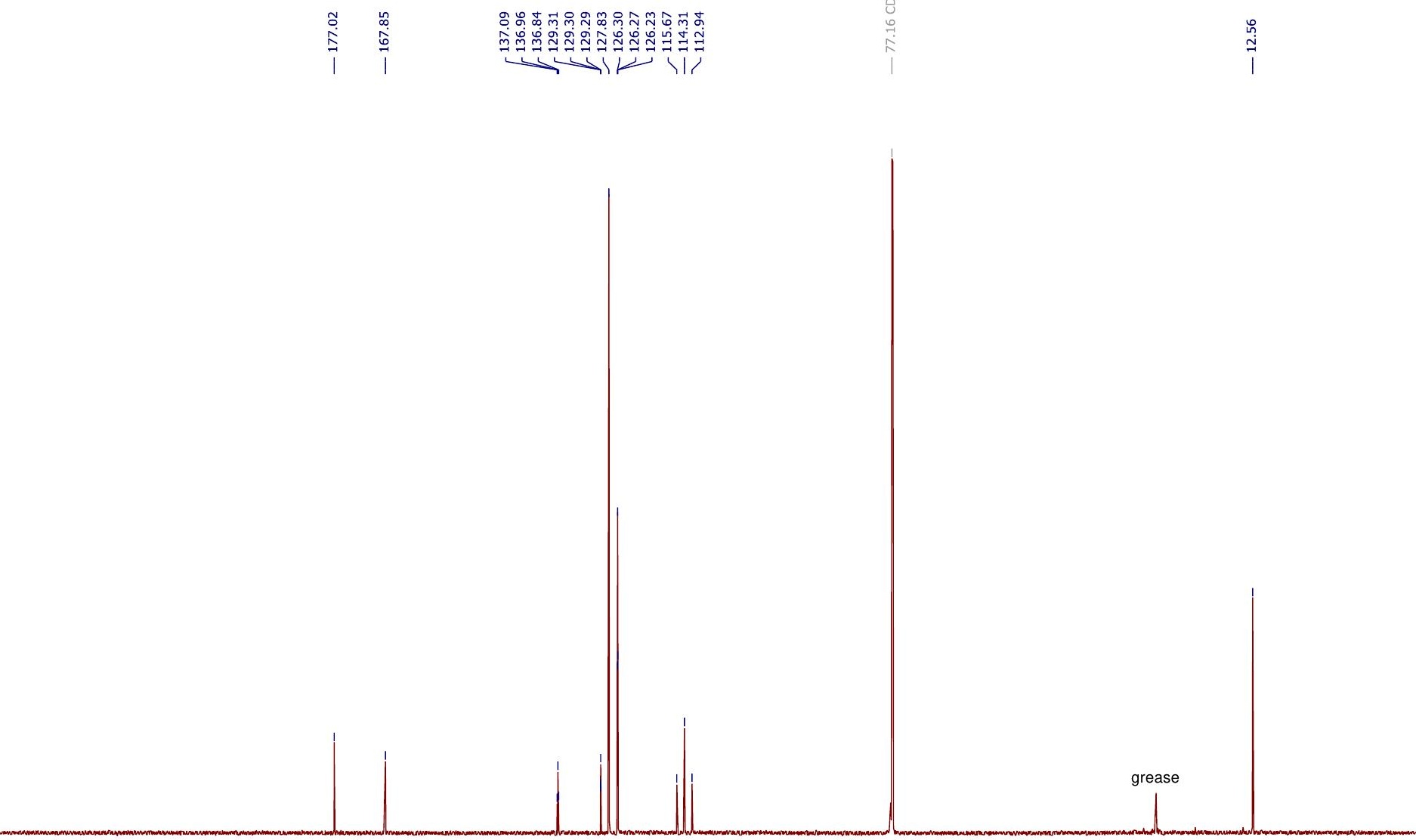

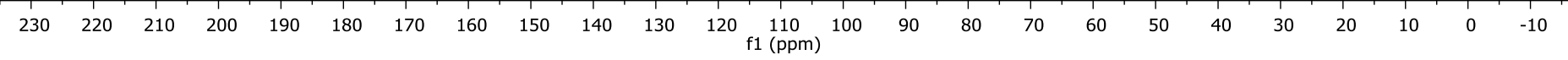




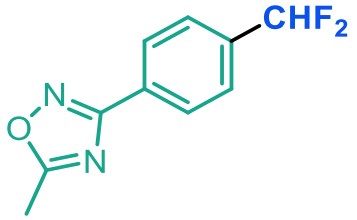

10

${ }^{19} \mathrm{~F}$ NMR

V

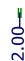

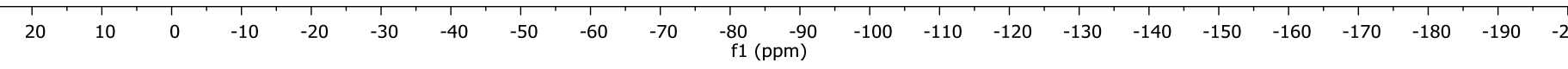


<smiles>CC(C)S(=O)(=O)c1ccc(C(F)F)cc1</smiles>

11

${ }^{1} \mathrm{H}$ NMR

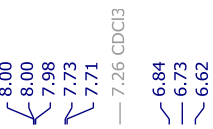

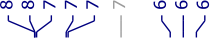

(1)
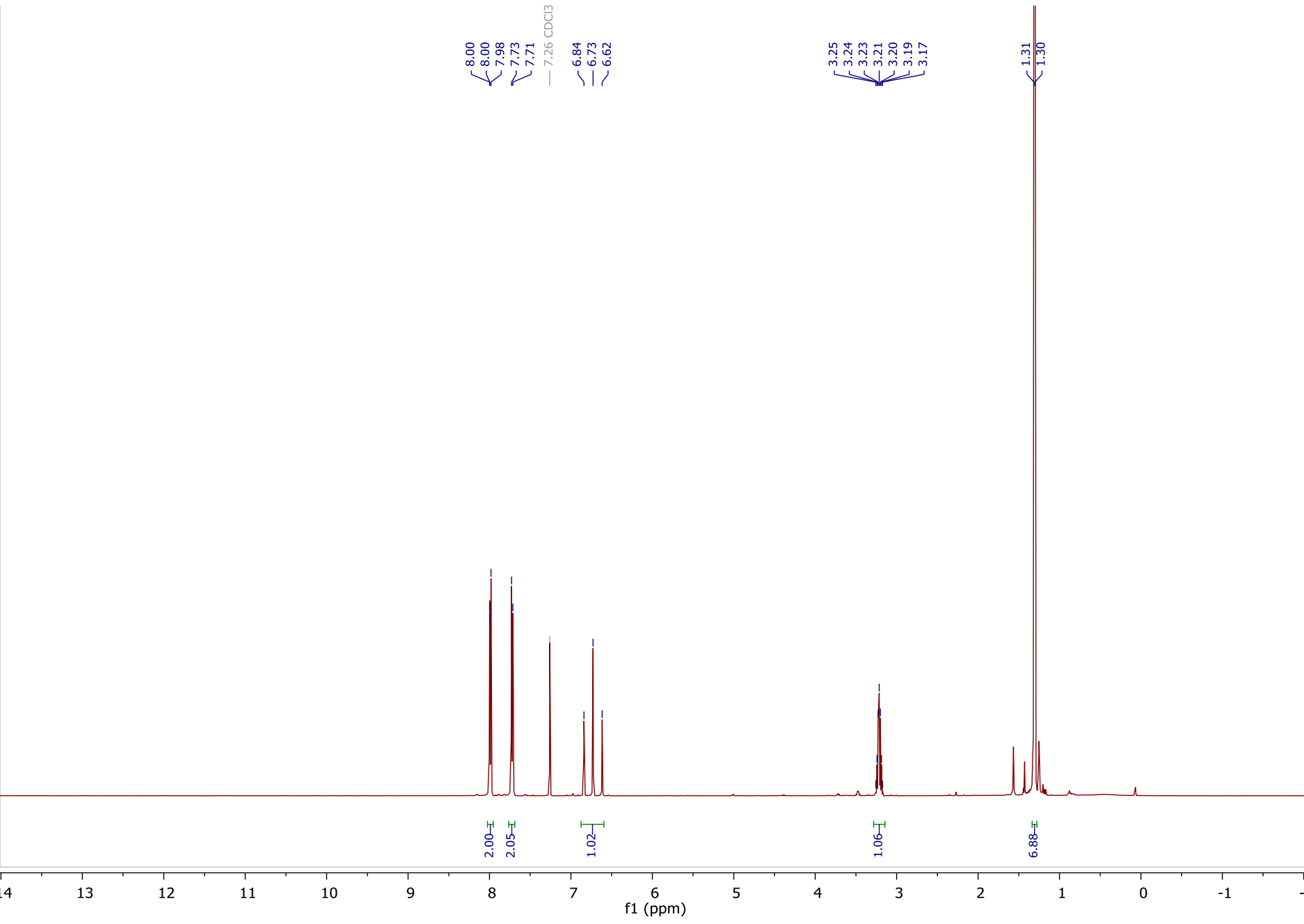
<smiles>CC(C)S(=O)(=O)c1ccc(C(F)F)cc1</smiles>

\section{1}

\section{${ }^{13} \mathrm{C}$ NMR}

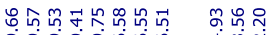

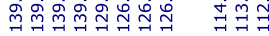

च

لvin

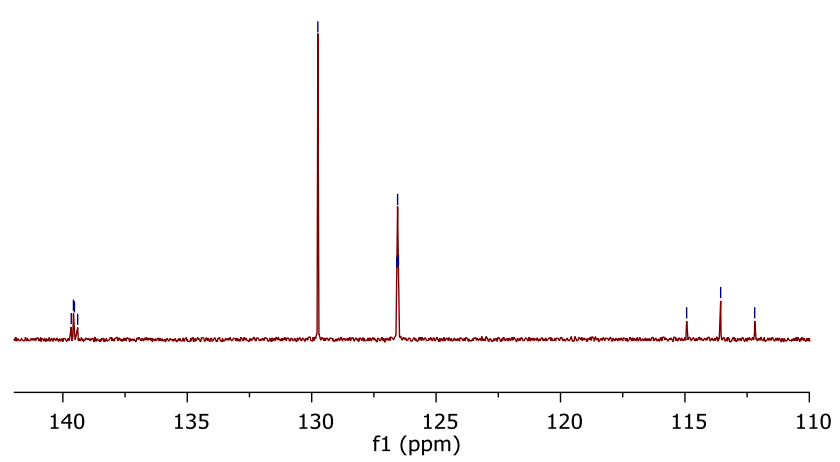

230

$230 \quad 220 \quad 210$

ఇำํำ

$\underset{7}{\exists} \underset{-1}{7}$ 


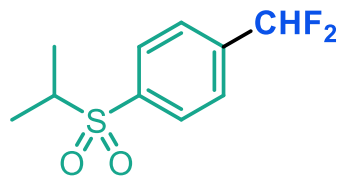

11

${ }^{19} \mathrm{~F}$ NMR

v

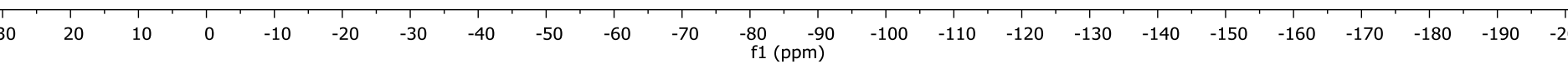




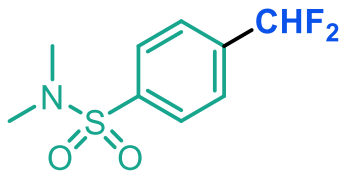

12

${ }^{1} \mathrm{H}$ NMR

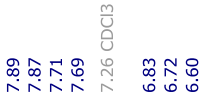

氙年

(12


<smiles>CN(C)S(=O)(=O)c1ccc(C(F)F)cc1</smiles>

12

${ }^{13} \mathrm{C}$ NMR
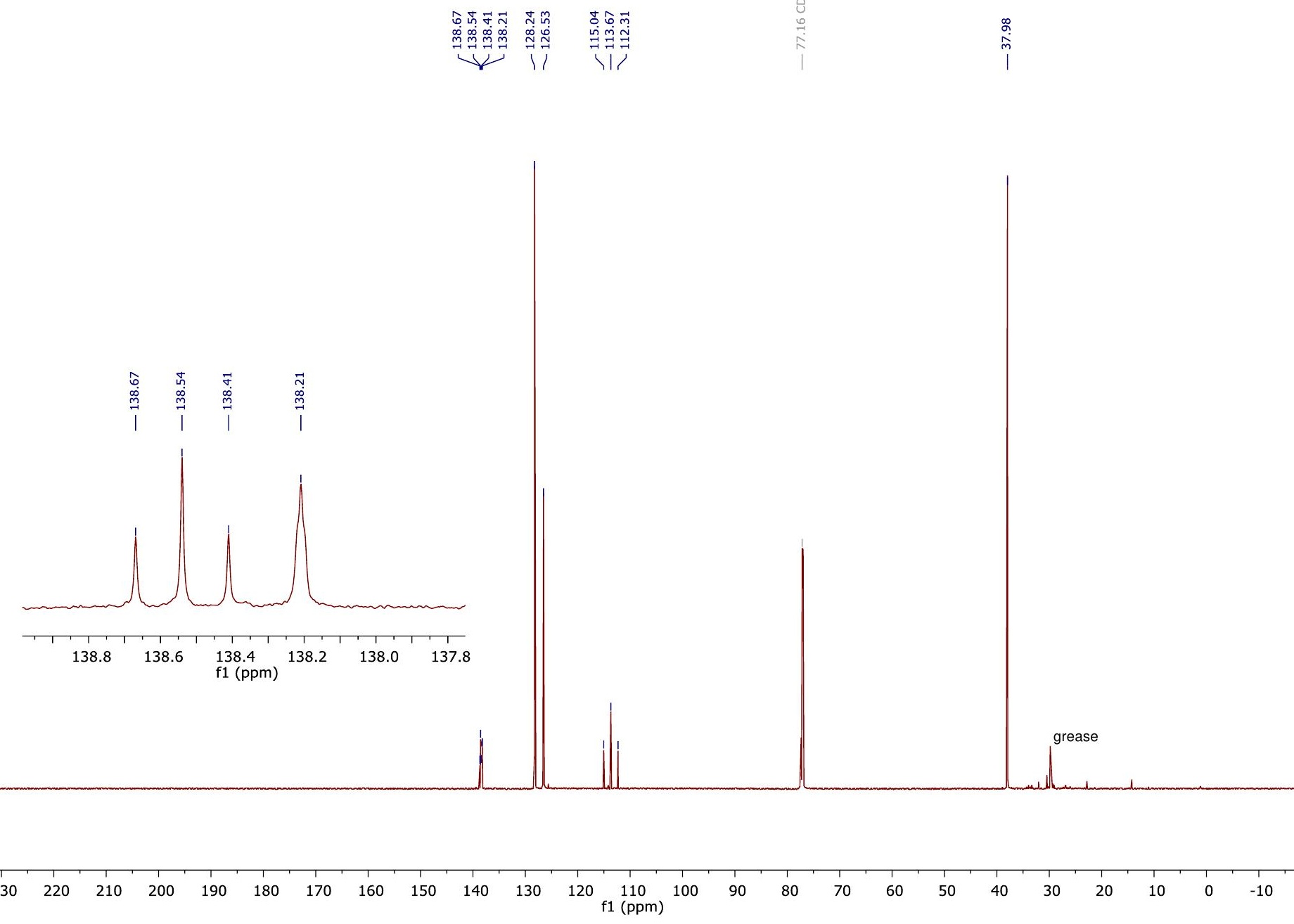


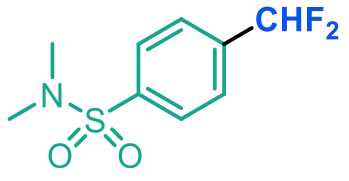

12

${ }^{19} \mathrm{~F}$ NMR

ن

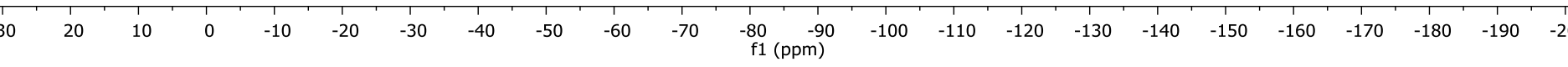


<smiles>CCCN(CCC)S(=O)(=O)c1ccc(C(F)F)cc1</smiles>

13

${ }^{1} \mathrm{H}$ NMR

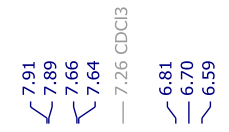

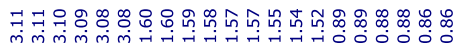
men

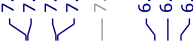
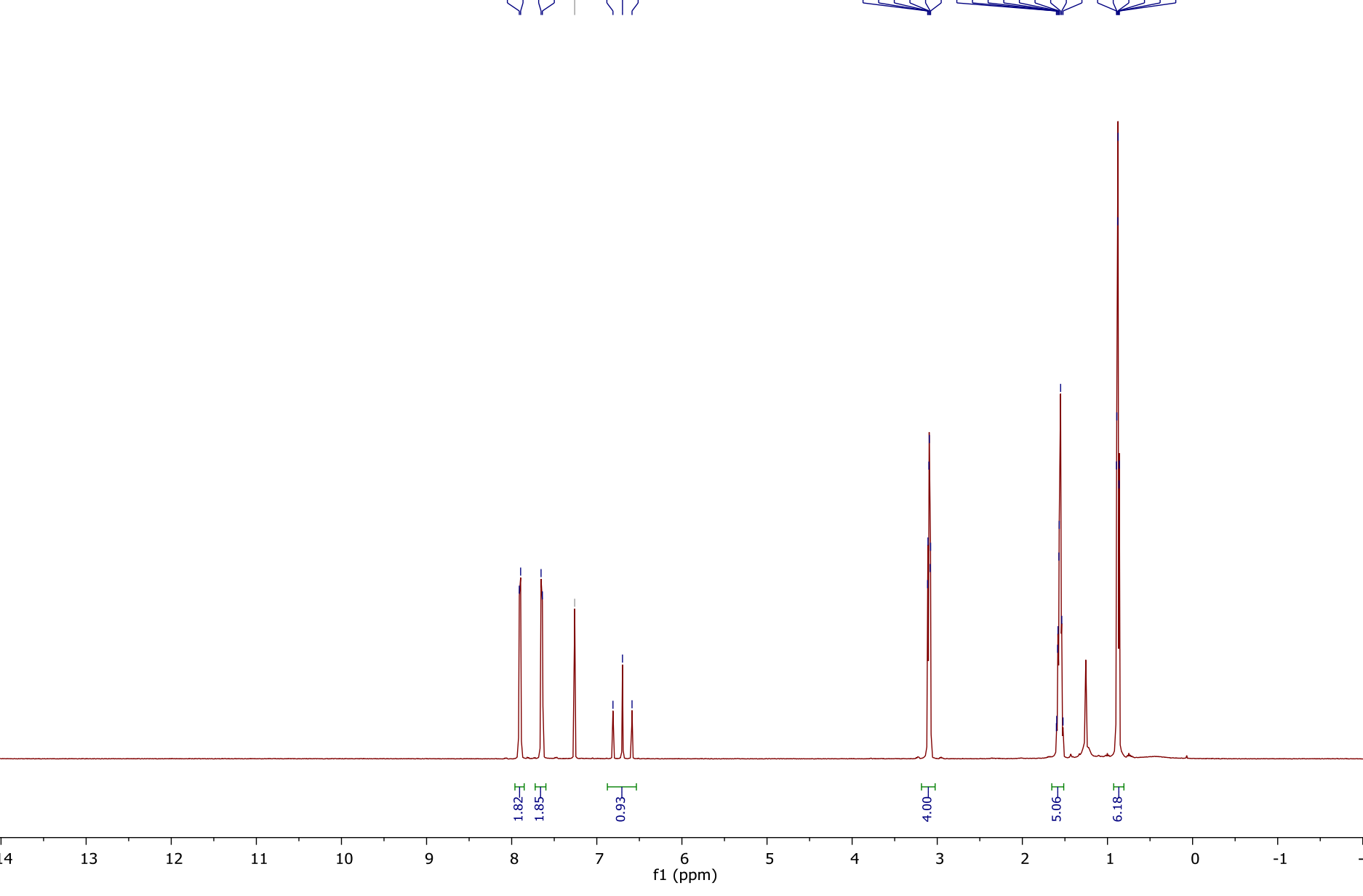
<smiles>CCCN(CCC)S(=O)(=O)c1ccc(C(F)F)cc1</smiles>

13

${ }^{13} \mathrm{C}$ NMR

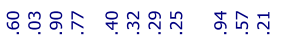

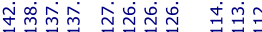

रे पर

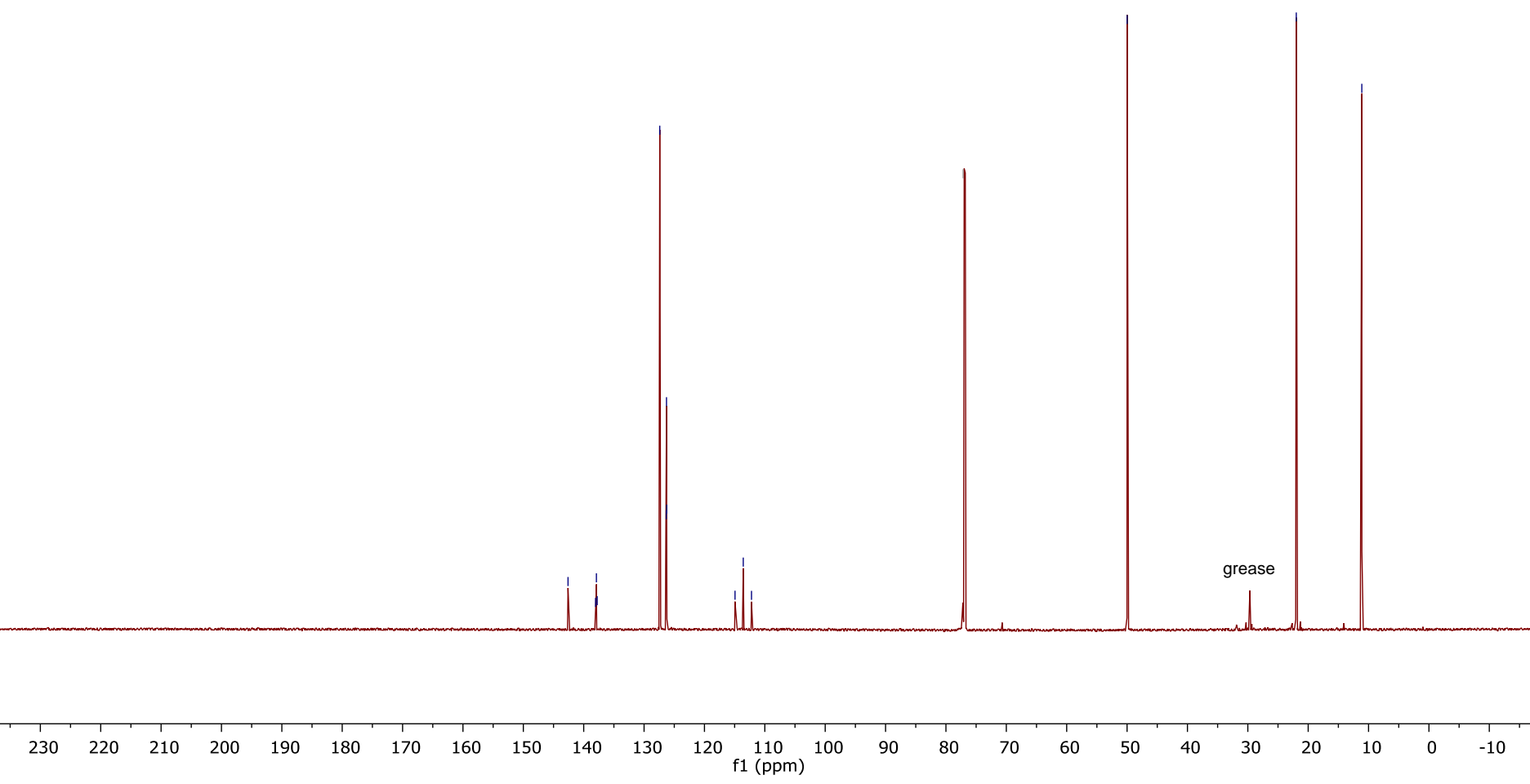




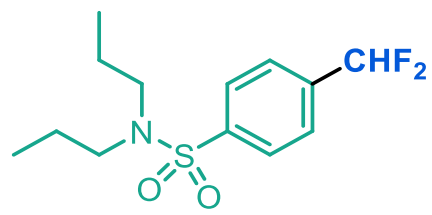

13

${ }^{19} \mathrm{~F}$ NMR

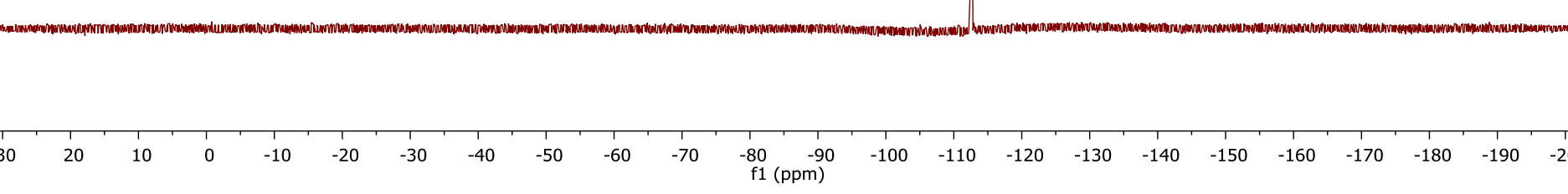



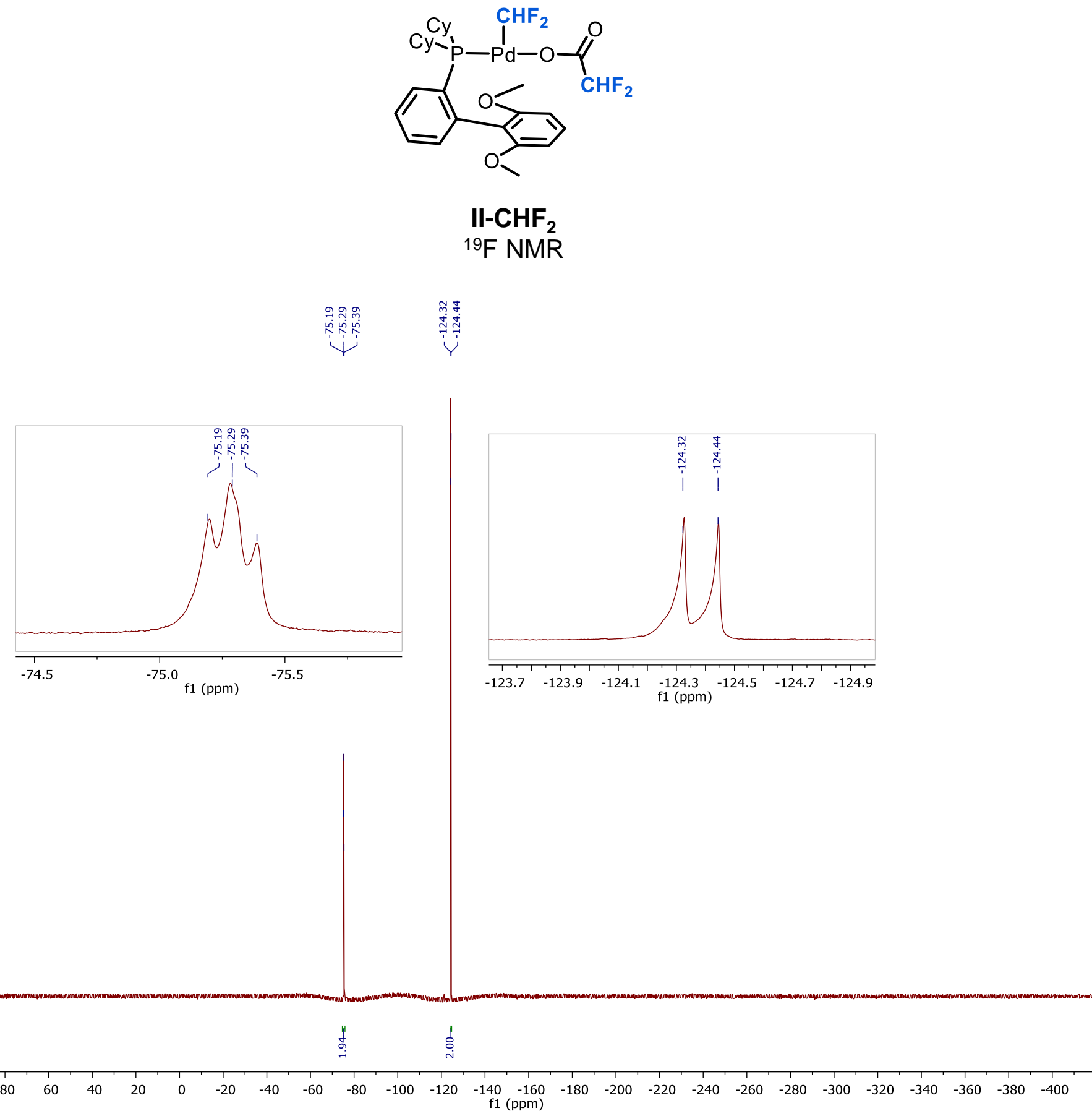

$\mathrm{S} 134$ 


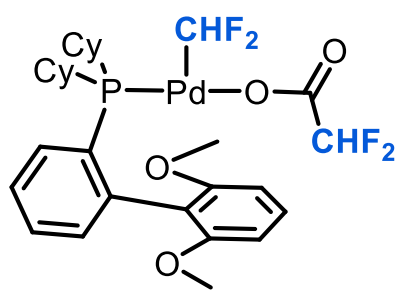

\section{II- $\mathrm{CHF}_{2}$ ${ }^{31} \mathrm{P}$ NMR}

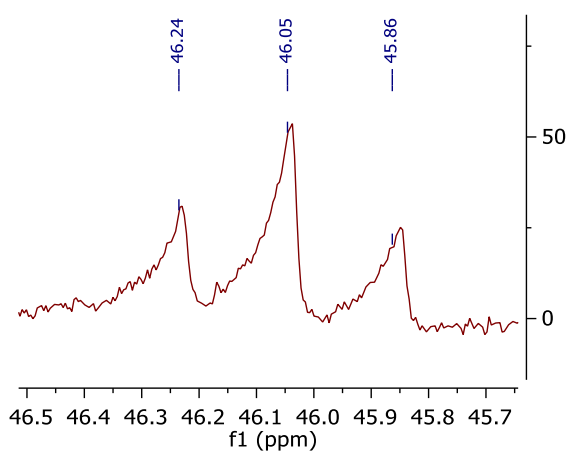

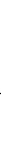




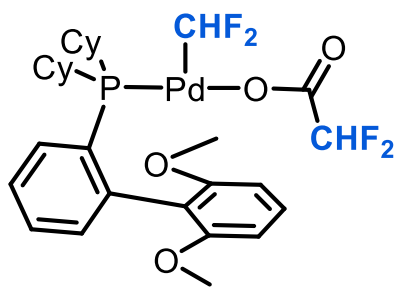

\title{
II-CHF
}

\author{
${ }^{1} \mathrm{H}$ NMR
}

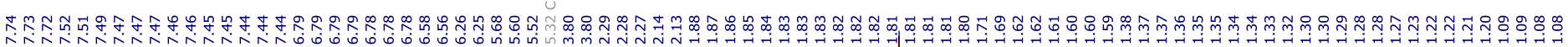




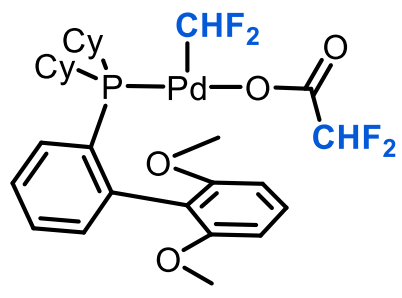

\section{II- $\mathrm{CHF}_{2}$} ${ }^{13} \mathrm{C} N M R$

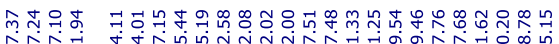

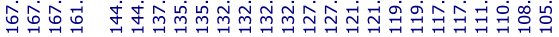

Y 